\title{
De rol van enige psycho-sociale risicofactoren in het ontstaan van een hartinfarct
}

Citation for published version (APA):

Otten, F. (1993). De rol van enige psycho-sociale risicofactoren in het ontstaan van een hartinfarct.

[Doctoral Thesis, Maastricht University]. Rijksuniversiteit Limburg. https://doi.org/10.26481/dis.19930325fo

Document status and date:

Published: 01/01/1993

DOI:

10.26481/dis.19930325fo

Document Version:

Publisher's PDF, also known as Version of record

\section{Please check the document version of this publication:}

- A submitted manuscript is the version of the article upon submission and before peer-review. There can be important differences between the submitted version and the official published version of record.

People interested in the research are advised to contact the author for the final version of the publication, or visit the DOI to the publisher's website.

- The final author version and the galley proof are versions of the publication after peer review.

- The final published version features the final layout of the paper including the volume, issue and page numbers.

Link to publication

\footnotetext{
General rights rights.

- You may freely distribute the URL identifying the publication in the public portal. please follow below link for the End User Agreement:

www.umlib.nl/taverne-license

Take down policy

If you believe that this document breaches copyright please contact us at:

repository@maastrichtuniversity.nl

providing details and we will investigate your claim.
}

Copyright and moral rights for the publications made accessible in the public portal are retained by the authors and/or other copyright owners and it is a condition of accessing publications that users recognise and abide by the legal requirements associated with these

- Users may download and print one copy of any publication from the public portal for the purpose of private study or research.

- You may not further distribute the material or use it for any profit-making activity or commercial gain

If the publication is distributed under the terms of Article $25 \mathrm{fa}$ of the Dutch Copyright Act, indicated by the "Taverne" license above, 
DE ROL VAN ENIGE PSYCHO-SOCIALE RISICOFACTOREN

IN HET ONTSTAAN VAN EEN HARTINFARCT 

DE ROL VAN ENIGE PSYCHO-SOCLALE RISICOFACTOREN

\section{IN HET ONTSTAAN VAN EEN HARTINFARCT}

\section{PROEFSCHRIFT}

ter verkrijging van de graad van doctor aan de Rijksuniversiteit Limburg te Maastricht, op gezag van de Rector Magnificus, Prof. Mr. M.J. Cohen, volgens het besluit van het College van Dekanen, in het openbaar te verdedigen op donderdag, 25 maart 1993, om 16.00 uur

door

Ferdy Otten 


\section{Promotores:}

Prof. Dr. A.P.W.M. Appels

Prof. Dr. F. Sturmans

\section{Beoordelingscommissie:}

Prof. Dr. J.W. van Ree (voorzitter)

Prof. Dr. M.J. Drop

Prof. Dr. A.J.A. Felling (Katholieke Universiteit Nijmegen)

Prof. Dr. M.W. de Vries

Dr. J.H. Schuurman (GVO/GGD Rotterdam)

Het verschijnen van dit proefschrift werd mede mogelijk gemaakt door steun van de Nederlandse Hartstichting.

ISBN-nummer: $90-9005708-0$

\section{Druk:}

Centraal Bureau voor de Statistiek 
HOOFDSTUK 1 De samenhang tussen sociaal-economische status, gezondheidsopvattingen, risicofactoren, cardiale mortaliteit en sterftekans. Gegevens van de KRIS follow-up studie

Samenvatting

1.1 Inleiding

1.1.1 Sociaal-economische status

1.1.2 SES en cardiovasculaire risicofactoren

1.1.3 SES en morbiditeit en mortaliteit ten gevolge van ischemische hartziekten

1.1.4 SES en totale mortaliteit en kankermortaliteit

1.1.5 Conclusie en vraagstelling

$\begin{array}{ll}1.2 & \text { Methoden van onderzoek } \\ 1.2 .1 & 26\end{array}$

$\begin{array}{ll}1.2 .1 \text { Inleiding } & 26\end{array}$

$\begin{array}{ll}\text { 1.2.2 Beschrijving van het onderzoekscohort } & 27\end{array}$

1.2.3 Gezondheidsopvattingen en cardiovasculaire risicofactoren

1.2.4 Morbiditeit en mortaliteit tijdens follow-up $\quad 30$

1.2.5 Operationalisatie van sociaal-economische status 34

$\begin{array}{ll}\text { 1.2.6 Statistische methoden } & 36\end{array}$

$\begin{array}{lll}1.3 & \text { Onderzoeksresultaten } & 38\end{array}$

1.3.1 De relatie tussen SES en gezondheidsopvattingen 38

1.3.2 De relatie tussen SES en cardiovasculaire risico-indicatoren

1.3.3 Samenvatting cross-sectionele resultaten

1.3.4 De relatie tussen SES en gezondheid, uitgedrukt in termen van hart- en vaatziekten

1.3.5 De relatie tussen SES en gezondheid, uitgedrukt in cardiale sterfte, kankersterfte en totale sterfte

1.3.6 Samenvatting follow-up resultaten.

1.4 Conclusie $\quad 62$

$\begin{array}{ll}\text { Literatuur } & 69\end{array}$

$\begin{array}{ll}\text { Appendix } 1 & 73\end{array}$

Appendix 2

Appendix $3 \quad 75$

Appendix 4 76

$\begin{array}{ll}\text { Appendix } 5 & 80\end{array}$ 
HOOFDSTUK 2 De KRIS follow-up studie II: Burgelijke staat en sterftekans

2.1 Inleiding 83

2.2 Methoden $\quad 84$

2.3 Resultaten $\quad 85$

2.4 Discussie 87

2.5 Abstract $\quad 88$

$\begin{array}{lll}2.6 & \text { Literatuur } & 89\end{array}$

HOOFDSTUK 3 De KRIS follow-up studie III: De effecten van roken op totale mortaliteit, hartinfarct en kanker van de luchtwegen

3.1 Inleiding 91

3.2 Methoden 92

3.3 Resultaten $\quad 93$

3.4 Discussie 97

3.5 Abstract 97

3.6 Literatuur 98

HOOFDSTUK 4 De KRIS follow-up studie IV: De invloed van alcoholconsumptie op infarctincidentie, cardiale mortaliteit en totale mortaliteit

4.1 Inleiding

101

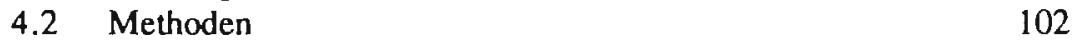

4.3 Resultaten 106

4.4 Discussie 108

4.5 Abstract 109

4.6 Literatuur 109

Appendix 111

HOOFDSTUK 5 De KRIS follow-up studie VI: Stress en cardiale mortaliteit

$5.1 \quad$ Inleiding

5.2 Methoden

5.3 Resultaten

5.4 Discussie

5.5 Abstract

5.6 Literanur 
HOOFDSTUK 6 De KRIS follow-up studie VIII: De relatie tussen familiale belasting en hart- en vaatziekten
6.1 Inleiding
6.2 Methoden
6.3 Resultaten
6.4 Discussie
6.5 Abstract
6.6 Literatuur

HOOFDSTUK 7 De KRIS follow-up studie XII: De relatie tussen lichamelijke inspanning en ischemische hartziekten

7.1 Inleiding

7.2 Methoden

7.3 Resultaten

7.4 Discussie

7.5 Abstract

7.6 Literatuur

HOOFDSTUK 8 Nabeschouwing

8.1 Inleiding

8.2 Voornaamste KRIS-bevindingen

8.3 Psycho-sociale en somatische effecten onderling vergeleken 154

8.4 Literatuur 


\section{INLEIDING}

Al geruime tijd zijn hart- en vaatziekten (HVZ) in Nederland een belangrijke oorzaak van sterfte. Het merendeel van deze hart- en vaatziekten komt voor rekening van de ischemische aandoeningen. Tabel I geeft een overzicht van het verloop van sterfte ten gevolge van HVZ en ischemische hartziekten vanaf de jaren vijftig.

Tabel 1 Tijdreeksen van sterftepercentages t.g.v. HVZ en ischemische hartziekten in Nederland (bron: CBS)

\begin{tabular}{|l|c|c|c|c|c|c|c|c|c|}
\hline & 1951 & 1956 & 1961 & 1966 & 1971 & 1976 & 1981 & 1986 & 1989 \\
\hline & $\%$ & $\%$ & $\%$ & $\%$ & $\%$ & $\%$ & $\%$ & $\%$ & $\%$ \\
\hline $\begin{array}{l}\text { Mannen: } \\
\text { aandeel HVZ sterfte } \\
\text { sterfie t.g.v. ische- } \\
\text { mische hartziekten 2) }\end{array}$ & 35 & 41 & 41 & 44 & 44 & 44 & 44 & 41 & 39 \\
\hline $\begin{array}{l}\text { Vrouwen: } \\
\text { aandeel HVZ sterfte 1) } \\
\begin{array}{l}\text { sterfie t.g.v. ische- } \\
\text { mische hartziekten 2) }\end{array}\end{array}$ & 40 & 45 & 45 & 47 & 46 & 47 & 47 & 44 & 41 \\
\hline
\end{tabular}

1) = als percentage van de totale sterfie in Nederland

2) = als percentage van de HVZ-sterfte

De tabel laat zien dat in Nederland het aandeel van de sterfte ten gevolge van hart- en vaatziekten het grootst was gedurende het midden van de jaren zestig en de jaren zeventig. Bij mannen bedroeg het sterftepercentage ten gevolge van hart- en vaatziekten $44 \%$ en bij vrouwen lag het rond de $47 \%$. Aan de HVZ-sterfte lag begin en midden jaren zeventig bij $61 \%$ van de mannen en bij $46 \%$ van de vrouwen een ischemische hartziekte ten grondslag. In de daaropvolgende periode is sprake van een dalende trend. Ook bij de HVZ-sterfte is sprake van een dalende trend. In 1989 bedroeg het aandeel HVZ-sterfte rond de $40 \%$. Hiervan wordt bij mannen ruim de helft en bij vrouwen ruim eenderde veroorzaakt door een ischemische hartziekte.

Ondanks de dalende trend in HVZ-sterfte en sterfte als gevolg van ischemische aandoeningen is het evident dat in Nederland anno 1992 nog steeds een grote groep mensen risico loopt op HVZ en ischemische hartziekten. Dit risico, ofwel de kans dat zich bij iemand in de toekomst een hart- en vaatziekte zal voordoen, wordt veroorzaakt door diverse risicofactoren. Tot de belangrijke cardiovasculaire risicofactoren worden gerekend verhoogde bloeddruk en verhoogd cholesterolgehalte. Ook het gedragskenmerk roken moet in dit rijtje worden geschaard. Andere gedragskenmerken waarvan is 
aangetoond dat ze het ontstaan van HVZ bevorderen, zijn geen of buitensporig alcoholgebruik, ongezonde eetgewoonten, gebrek aan lichamelijke inspanning en stress. Naast voomoemde gedragskenmerken zijn er ook empirische gegevens voor de schadelijke werking van diverse vormen van belastende levensgebeurtenissen, ontbreken van sociale steun en lage sociaal-economische status.

Over de in cardiovasculair opzicht schadelijke werking van verhoogde bloeddruk en verhoogd cholesterolgehalte bestaat in de epidemiologie weinig twijfel. Voor de risicofactor roken geldt dit evenzeer. Voor de andere zojuist genoemde psycho-sociale kenmerken is de wetenschappelijke bewijsvoering soms minder krachtig. Een belangrijke reden hiervoor is in de eerste plaats dat naar deze kenmerken minder onderzoek is gedaan. Een verder beperkend punt is dat bij dergelijke onderzoeken veelal onderzoeksontwerpen zijn gehanteerd waarmee de oorzaak-gevolg relatie niet eenduidig kan worden vastgelegd. Strikt genomen is een oorzaak-gevolg relatie nimmer te bewijzen. Ook niet met behulp van statistische procedures. De statistiek levert nu eenmaal geen uitsluitsel over de richting van een relatie maar levert alleen een effectkwantificering voor de door de onderzoeker veronderstelde richting van deze relatie. Een gedeeltelijk antwoord op de vraag of een bepaalde relatie te beschouwen is als een oorzaak-gevolg relatie, is afkomstig van de methodenleer. Deze stelt dat causaliteit minimaal moet voldoen aan de volgende drie voorwaarden: de oorzaak gaat in de tijd vooraf aan het gevolg, er is een samenhang tussen oorzaak en gevolg en deze samenhang is geen schijnsamenhang (de samenhang komt niet tot stand door verstorende kenmerken). Aan de eerste causaliteitsvoorwaarde kan alleen worden voldaan als het onderzoeksontwerp voorziet in de noodzakelijke tijdsvolgorde van oorzaak- en gevolgmetingen. De voorwaarden van samenhang en geen schijnsamenhang kunnen met behulp van statistische procedures worden gecontroleerd.

De eerste minimale causaliteitsvoorwaarde bepaalt voor een belangrijk deel welke onderzoeksvorm het meest geschikt is voor adequaat epidemiologisch onderzoek. Zo is transversaal of dwarsdoorsnede onderzoek minder geschikt voor causaal epidemiologisch onderzoek omdat oorzaak en gevolg tegelijkertijd gemeten worden. Casecontrol of case-referent onderzoek, waarin hart- en vaatpatiënten met een representatieve groep personen zonder hart- en vaatziekten worden vergeleken, kent ook zijn beperkingen. Weliswaar is in een dergelijk ontwerp een tijdsas ingebouwd - er wordt immers op retrospectieve wijze naar de oorzaak gevraagd - doch ook hier zijn problemen met de causaliteit, daar het gevolg al bekend is voordat de oorzaak wordt gemeten. Daar komt nog bij dat het soms onmogelijk is om überhaupt kenmerken te meten die in de tijd terugliggen. Een cohort studie of een follow-up studie waarin een van aanvang af gezonde groep mensen wordt gevolgd op het voorkomen van hart- en vaatziekten, komt wellicht het meest tegemoet aan de causaliteitsvoorwaarden. Alle relevante kenmerken worden in het begin van de studie gemeten en gaan daarom in de tijd vooraf aan het gevolg. Wanneer de follow-up een langere periode bestrijkt, is het van belang de oorspronkelijke metingen te herhalen. Dit om rekening te kunnen houden met eventuele veranderingen van exposities. 
Tot en met de begin jaren tachtig was de hoeveelheid follow-up onderzoek naar mogelijke psychologische en sociologische oorzaken van hart- en vaatziekten in Nederland praktisch nihil. Voor het toenmalige Ministerie van Volksgezondheid en Milieuhygiëne, alsmede het Praeventiefonds en de Nederlandse Hartstichting was het gebrek aan empirische gegevens aanleiding om in 1970 groen licht te geven aan een grootscheeps follow-up onderzoek naar psycho-sociale cardiovasculaire risicofactoren bij een aselecte steekproef van 3365 Rotterdamse mannen in de leeftijd van 45-59 jaar. Dit Rotterdamse cohort, onderdeel van de zogenoemde Kaunas-Rotterdam InterventionStudy (KRIS), werd tussen 1972 en 1974 uitgebreid gescreend op zowel somatische als psycho-sociale cardiovasculaire risicofactoren. In 1982 zijn voor dit KRIS-cohort via het Centraal Bureau voor de Statistiek de diverse overlijdensoorzaken voor een follow-up van 91/2 jaar verkregen. Verder werd in 1982 onder de nog in leven zijnde KRIS-deelnemers een morbiditeitsonderzoek gehouden, waarmee de incidentie van ischemische hartziekten kon worden vastgesteld. Aldus konden in een prospectief ontwerp diverse relaties tussen enerzijds psycho-sociale kenmerken en anderzijds ischemische hartziekten en sterfte worden bestudeerd. Een beperking van deze studie was evenwel dat de psycho-sociale kenmerken niet herhaald gemeten zijn gedurende de follow-up. Met eventueel opgetreden veranderingen kon daarom geen rekening worden gehouden. Ondanks deze tekortkoming lijken de KRIS-bevindingen wetenschappelijk en maatschappelijk relevant. Zo geven de KRIS-bevindingen een historisch beeld van de werking van diverse somatische en psycho-sociale risicofactoren voor een periode waarin de incidentie van ischemische sterfte-oorzaken in Nederland haar hoogtepunt kende. Naast het belang van de epidemiologische geschiedschrijving vormen de resultaten tevens de basis voor extrapolatie naar de huidige situatie. De diverse relatieve risico's en de daarvan afgeleide populatie attributieve risicopercentages leren welke psycho-sociale kenmerken de Nederlander de meeste hartschade toebrengen. Op grond van deze inzichten kunnen efficiënte beleidsprogramma's worden opgezet om het aandeel hart- en vaatziekten in onze samenleving verder terug te dringen.

Onderhavige dissertatie is een bundeling van een aantal publikaties over de resultaten van de KRIS follow-up studie zoals die vanaf 1988 tot op heden zijn verschenen.

Hoofdstuk 1 is nagenoeg een integrale weergave van een rapport over sociaaleconomische gezondheidsverschillen zoals dat in 1989 is uitgebracht in opdracht van het Ministerie van Welzijn, Volksgezondheid en Cultuur. In het hoofdstuk wordt de samenhang beschreven tussen enerzijds sociaal-economische status (SES) en anderzijds opvattingen over gezondheid, cardiovasculaire risicofactoren, ischemische hartziekten en (kanker)sterfte. Het sociologische kenmerk sociaal-economische status is hier weergegeven door beroep, opleiding, wijk waarin men woont en een samengestelde index, waarin naast deze drie kenmerken ook het beroep na het afsluiten van de opleiding en het beroep van de vader is opgenomen. Verder wordt in dit hoofdstuk stilgestaan bij de oorspronkelijke doelstellingen van het screeningsonderzoek in 1972-1974, de steekproeftrekking en het additionele morbiditeits- en mortaliteitsonderzoek in 1982. 
Hoofdstuk 2 gaat in op het effect van burgerlijke staat op cardiale sterfte en totale sterfte. Onderzocht wordt of al dan niet hebben van een partner, wat geïnterpreteerd kan worden als een indicator voor sociale steun, van invloed is op beide eindpunten.

In hoofdstuk 3 wordt het effect van roken op ischemische eindpunten en (kanker)sterfte beschreven. Het gedragskenmerk roken is onderscheiden in nooit-rokers, voormalige rokers, pijp- of sigarenrokers, personen die 1-9 sigaretten per dag roken en personen die 10 of meer sigaretten per dag roken.

Hoofdstuk 4 behandelt het effect van het gedragskenmerk alcoholconsumptie op ischemische hartziekten en sterfte. Het kenmerk alcoholconsumptie geeft zowel uitdrukking aan de drinkfrequentie als aan de genuttigde drinkhoeveelheid en is als zodanig als een ordinale meting te beschouwen. Nagegaan is ondermeer of het zo veelvuldig gerapporteerde U-vormige effect tussen alcoholgebruik en ischemische aandoeningen door de KRIS-gegevens bevestigd wordt.

In hoofdstuk 5 wordt verslag gedaan van het predictieve vermogen van stress gemeten met de zogenoemde 'Reeder stress scale'. Aan de kwaliteiten van deze in onbruik geraakte stress-schaal bestaat enige twijfel. Wel bevat deze schaal een item dat verwijst naar ongewone vermoeidheid. Van ongewone vermoeidheid is bekend dat het een sterk voorspellende betekenis heeft op het optreden van hart- en vaatziekten. Er zijn dan ook aparte analyses uitgevoerd om na te gaan of gevoelens van uitputting, zoals gemeten door dit Reeder-item, cardiovasculaire betekenis heeft.

In hoofdstuk 6 staat de relatie centraal tussen familiale belasting en hart- en vaatziekten. Hoewel familiale belasting in eerste instantie lijkt te verwijzen naar een erfelijke component, is dit kenmerk voor een deel ook als een sociologische factor te beschouwen. Het kan immers verwijzen naar bepaalde omgevingsfactoren die de onderzoekspersoon gemeenschappelijk heeft met zijn directe familieleden. Familiale belasting is gemeten als het voorkomen van een hartinfarct, een hersenbloeding of plotselinge dood bij naaste familieleden. Bij deze drie kenmerken is telkens onderscheiden of de belasting alleen bij ouders, bij broers of zussen of bij zowel ouders als broers of zussen voorkwam.

Hoofdstuk 7 gaat in op de relatie tussen lichamelijke inspanning en ischemische hartziekten. Het beschrijft in welke mate personen met minder zware lichamelijke activiteit in het beroep, in het woon-werk verkeer en in de vrije tijd alswel personen met minder zware inspanning op de voomoemde vlakken tezamen genomen een verhoogd risico op ischemische hartziekten hebben.

In hoofdstuk 8 tenslotte worden de meest wezenlijke onderzoeksbevindingen naast elkaar gezet. Verder worden de attributieve risicopercentages van zowel de somatische als de diverse psycho-sociale risicofactoren met elkaar vergeleken. Aldus wordt inzicht gegeven in het relatieve belang van de diverse risicofactoren op het ontstaan van ischemische hartziekten. 
Hoofdstuk 1 is een nagenoeg integrale weergave van een rapport over sociaal-economische gezondheidsverschillen. Deze in 1989 verschenen publicatie is samengesteld in opdracht van het Ministerie van Welzijn, Volksgezondheid en Cultuur. 



\title{
HOOFDSTUK 1 \\ De samenhang tussen sociaal-economische status, gezondheidsopvattingen, risicofactoren, cardiale mortaliteit en sterftekans. Gegevens van de KRIS follow-up studie
}

\author{
(F. Otten, C.F. Mendes de Leon, A. Appels)
}

\section{SAMENVATTING}

In dit rappon wordt verslag gedaan over de samenhang tussen sociaal-economische status (SES) enerzijds en opvattingen over gezondheid, cardiovasculaire risicofactoren en sterfiekansen anderzijds. De gegevens zijn ontleend aan een onderzoek bij 3365 Rotterdamse mannen van 45-60 jaar. Deze groep werd in 1972/1973 onderzocht op cardiovasculaire risicofactoren en daarna $91 / 2$ jaar gevolgd. SES werd op vier manieren vastgesteld: beroep, opleiding, wijk waarin men woont en een samengestelde index, waarin naast deze drie variabelen ook het beroep na het afsluiten van de opleiding en het beroep van de vader was opgenomen.

Mannen uit de lagere strata bleken de kans op het krijgen van een ermstige ziekte hoger in te schatten dan mannen uit de hogere strata. Zij vonden ook vaker dat er weinig of niets aan te doen is om een ziekte te voorkomen.

SES bleek in 1972 geen samenhang te hebben met de cardiovasculaire risicofactoren, met uitzondering van roken en alcoholconsumptie. Roken en geheelonthouding kwamen meer voor in de lagere strata, terwijl matig alcoholgebruik meer prevalent was in de hogere strata.

SES bleek niet samen te hangen met de kans op het krijgen van een al dan niet fatale hartziekte. Mannen met een laag beroepsniveau hadden meer kans op sterfie ten gevolge van kanker. Dit bleek toe te schrijven aan verschillen in roken en burgerlijke staat. Mannen uit de hoogste SES-wijk hadden minder kans op sterfte ten gevolge van kanker of sterfie ten gevolge van welke oorzaak dan ook. In het hoogste beroepsniveau was ook de kans op totale sterfie lager dan in de andere niveau's. De samengestelde index gaf geen duidelijke aanwijzing voor een verband tussen SES en sterfiekansen. 


\subsection{INLEIDING}

Dit rapport beoogt een bijdrage te leveren aan het beantwoorden van de vraag of er ook in Nederland sociaal-economische gezondheidsverschillen bestaan (1). Deze thematiek was aanleiding voor de Wetenschappelijke Raad voor het Regeringsbeleid in 1987 een conferentie te houden over de ongelijke verdeling van gezondheid (2). Het voornaamste bestanddeel van dit rapport zal bestaan uit het verslag van enige exploratieve resultaten van de Kaunas Rotterdam Intervention Study (KRIS). De KRIS was een preventief onderzoek naar cardiovasculaire en totale mortaliteit, uitgevoerd tussen 1972 en 1981 bij een groep van 3365 mannen van 45 tot 60 jaar (3). Met de KRISgegevens is op exploratieve wijze onderzocht of er in Nederland sprake is van gezondheidsverschillen tussen sociaal-economische groepen voor wat betreft ischemische hartziekten en sterfte. Het eerste deel van dit rapport is voornamelijk gewijd aan een overzicht van de belangrijkste binnen- en buitenlandse onderzoeksgegevens over het verband tussen sociaal-economische status enerzijds en bepaalde gezondheidsrisico's, morbiditeit en mortaliteit ten gevolge van ischemische hartziekten, en mortaliteit in het algemeen anderzijds. Alvorens hierop in te gaan, wordt eerst het concept sociaal-economische status nader toegelicht.

\subsubsection{Sociaal-economische status}

Iedere maatschappij kenmerkt zich door een bepaalde verdeling van schaarse goederen over de diverse categorieën van mensen. Deze schaarse goederen omvatten niet alleen datgene wat in geld kan worden uitgedrukt, maar alles wat bepalend is voor de menselijke levenskansen. Binnen de sociologie is het veelal gebruikelijk om bij schaarse goederen Weber's driedeling van sociale klasse, status en politieke macht aan te houden (4). Sociale klasse is te beschouwen als een economisch concept. Het verwijst naar eigendomsverhoudingen en controle over materiële hulpbronnen. Status verwijst naar de mate van prestige of eer die men in een gemeenschap of samenleving geniet. Het maatschappelijke aanzien heeft betrekking op allerhande sociale en culturele kenmerken die medebepalend zijn voor de menselijke levenskansen. Voorbeelden hiervan zijn familie-afkomst, leefstijlen en sociale netwerken. Politieke macht, tenslotte, verwijst naar een specifieke vorm van machtsmiddelen. De mate waarin men over dergelijke machtsmiddelen beschikt, is voor een belangrijk deel bepalend voor de plaats die men inneemt in de maatschappelijke verdelingsstructuur. Als indicatoren voor sociale stratificatie worden in de sociologie doorgaans beroep, opleiding en inkomen genomen. Deze kenmerken hebben vooral betrekking op de door Weber onderscheiden concepten sociale klasse en status. Beroepsmetingen zijn voor het merendeel gebaseerd op een of andere vorm van rangschikking van de verschillende beroepen. Deze rangschikking kan plaatsvinden op grond van prestigewaarderingen van de diverse beroepen (door externe beoordelaars) of op grond van bekwaamheidscriteria zoals 
benodigd onderwijsniveau, richting van het onderwijs, specifieke ervaringskennis en zelfstandigheid in het werk. Metingen van het beroepsprestige hebben betrekking op Weber's statusconcept, terwijl beroepsclassificaties op grond van bekwaamheidscriteria naar zowel sociale klasse als status verwijzen. Ook bij onderwijsmetingen is er sprake van onderlinge verwevenheid van de concepten sociale klasse en status. Enerzijds houdt de hoeveelheid genoten onderwijs verband met bepaalde gedrags- en handelingspatronen die van invloed zijn op iemand's leefstijl en sociale netwerken (status). Anderzijds voorziet het genoten onderwijs in de kwalificaties die nodig zijn om bepaalde beroepen te kunnen uitoefenen en om een bepaald inkomen te verwerven (sociale klasse). Zoals zojuist is aangegeven, is inkomen vooral te beschouwen als een indicator van sociale klasse. Echter ook voor deze indicator geldt dat er een bepaalde overlap met status kan bestaan. Inkomen kan bepalend zijn voor de opleidingsmogelijkheden en aldus mede van invloed zijn op leefstijlen en genoten prestige. Een en ander betekent dat evenals de gehele maatschappeijke verdelingsstructuur, ook de diverse afzonderlijke indicatoren van deze structuur gekenmerkt worden door multidimensionaliteit. Zuivere conceptuele scheidslijnen ussen SES-dimensies en tussen diverse deelcomponenten van een afzonderlijke dimensie zijn dan ook nimmer te trekken.

Anders dan in de sociologie worden in de epidemiologie de verdelingskenmerken niet als te verklaren variabelen maar als verklarende variabelen (voor gezondheid) gebruikt. Tot op heden is het evenwel nog onduidelijk welke indicatoren van sociale stratificatie het meest relevant zijn om gezondheidsverschillen te onderzoeken. Net als in de sociologie wordt veelvuldig gebruik gemaakt van de standaardindicatoren beroep, opleiding en inkomen. Omdat deze indicatoren naar zowel sociale als economische hulpbronnen verwijzen, worden ze in de epidemiologie doorgaans aangeduid als kenmerken van sociaal-economische status (SES). Van de standaard SES-indicatoren zijn in deze bijdrage alleen het beroep en de opleiding van de respondenten gebruikt. Het beroep is gebaseerd op een door het Instituut voor Toegepaste Sociale Wetenschappen (ITS) ontwikkelde beroepenclassificatie (48). De criteria die aan deze classificatie ten grondslag liggen, zijn arbeidssector, in loondienst of zelfstandig werken en (al of niet) leiding geven. Aldus verwijst het beroep evenals de opleiding, naar de verdelingsdimensies sociale klasse en prestige. De SES-indicator inkomen is niet bij het onderzoek betrokken, omdat in de KRIS-studie geen inkomensmetingen zijn verricht. Behalve van beroep, opleiding en inkomen wordt in het epidemiologisch onderzoek soms gebruik gemaakt van contextuele SES-metingen en van samengestelde indices. Omdat het bestand van de KRIS-studie gebaseerd is op een gestratificeerde steekproeftrekking met vier verschillende SES-wijken als eenheid van stratificatie, is tevens de variabele SESwijk in het onderzoek meegenomen. Daar deze SES-bepaling mede gebaseerd is op beroeps- en opleidingsgegevens van de in deze wijken woonachtige kostwinners, geldt dat de omgevingsfactor SES-wijk verwijst naar onderscheiden, algemene niveau's van prestige en sociale klasse in de wijken. Vanwege de overlap tussen de verschillende SES-indicatoren voor wat betreft enige maatschappelijke verdelingsdimensies, is in 
deze bijdrage met behulp van factoranalyse een index samengesteld die uitdrukking geeft aan de gemeenschappelijke component van diverse SES-indicatoren. Deze index is gebaseerd op beroeps- en opleidingsgegevens van de respondent, het beroep van de vader en het type SES-wijk waarin de respondent woont. Omdat aan deze index metingen van zowel sociale klasse als prestige ten grondslag liggen, wordt verondersteld dat deze unidimensionele maat de gemeenschappelijkheid van voomoemde stratificatievormen weergeeft.

Het literatuuroverzicht is vooral gericht op beroeps- en opleidingsniveau, aangezien deze SES-indicatoren de spil vormen van onderhavig onderzoek. Eerst komen de SES-verschillen ten aanzien van gezondheidsrisico's aan bod. Onder gezondheidsrisico's worden vooral indicatoren verstaan die een verhoogde kans geven op het krijgen van hart- en vaatziekten, met name roken, bloeddruk, cholesterolgehalte van het bloed, alcoholgebruik en overgewicht. Daarna worden onderzoeksgegevens besproken met betrekking tot het verband tussen SES en coronaire morbiditeit en mortaliteit. Het laatste deel behandelt SES-verschillen ten aanzien van mortaliteit in het algemeen en mortaliteit ten gevolge van kanker.

\subsubsection{SES en cardiovasculaire risicofactoren}

Het onderzoek naar gezondheidsrisico's bij verschillende sociaal-economische klassen is een van de wijzen waarop sociaal-economische gezondheidsverschillen bestudeerd kunnen worden. De achterliggende gedachte is dat mensen uit min of meer onderscheiden SES-groepen verschillen in riskante gewoonten, en daarom verschillen met betrekking tot risico-indicatoren van bijvoorbeeld hart- en vaatziekten. Dit gegeven zou dan mede de ziekte- en sterfteverschillen tussen SES groepen kunnen verklaren.

Een aanzienlijke hoeveelheid onderzoek lijkt uit te wijzen dat er over het algemeen een omgekeerd verband bestaat tussen sociale klasse en prevalentie van cardiovasculaire risico-indicatoren. Dat is het duidelijkst aangetoond voor roken en hoge bloeddruk. Verscheidene buitenlandse bevolkingsonderzoeken uit de jaren zestig en zeventig vonden dat in lagere SES-klassen meer gerookt werd $(5,6,7)$ en dat daar de prevalentie van hoge bloeddruk hoger was $(5,7,8)$. Niet alle resultaten uit buitenlands onderzoek zijn hiermee in overeenstemming. In de Framingham-Study bijvoorbeeld, was er geen duidelijk verband tussen opleiding of beroepsstatus ("white-collar" vs. "blue-collar") en bloeddruk. Er werd ook geen relatie gevonden tussen rookgedrag en opleiding, maar wel met beroepsstatus: "blue-collar workers" rookten significant meer, na correctie voor leeftijd en relatief gewicht, dan "white"-collar workers", al gold deze relatie alleen voor de mannen in dit onderzoek (9). In een recent Noors bevolkingsonderzoek, de Tromso Heart Study, werd wel een significant negatief verband aangetoond, na correctie voor leeftijd en andere factoren, tussen opleiding en zowel percentage rokers als systolische bloeddruk (10). 
Uit Nederlands onderzoek is eveneens naar voren gekomen dat roken en andere risicofactoren voor cardiovasculaire ziekten vaker in lagere SES-klassen voorkomen (11). Daarbij moet opgemerkt worden dat toegenomen rookgedrag onder vrouwen uit lagere SES-groepen een relatief recente ontwikkeling is, terwijl dat voor mannen reeds sinds de jaren zestig is waargenomen (12). Recent epidemiologisch onderzoek in Nederland laat zien dat het percentage rokers minder hoog is bij hoger opgeleide mannen dan bij lager opgeleide mannen. Bij vrouwen waren er echter minder sterke verschillen naar opleidingsniveau (13). Systolische bloeddruk had in hetzelfde onderzoek geen duidelijk verband met opleidingsniveau, al lagen de gemiddelde waarden bij de hoger opgeleide mannen en vrouwen wel lager dan bij de minder hoog opgeleiden (13).

De bevindingen met betrekking tot het verband tussen SES-indicatoren en serumcholesterolgehalte lijken minder consistent. Uit een Amerikaans bevolkingsonderzoek (The National Health and Nutrition Examination Survey) is bijvoorbeeld gebleken dat er begin jaren zestig nog geringe verschillen bestonden in cholesterolgehalte naar opleidingsniveau, en dat die verschillen aan het eind van de jaren zeventig nagenoeg verdwenen waren (14). In een overzicht van drie epidemiologische studies in Chicago werd eveneens geen verband tussen opleidingsniveau en cholesterolgehalte geconstateerd (15). Een andere Amerikaanse studie vond alleen een negatieve relatie tussen SES-klasse en hypercholesterolemie voor blanke bevolkingsgroepen (16). In de Framingham studie werd geen enkel verband ussen opleidings- of beroepsniveau en cholesterol gevonden (9). In twee Noorse studies werden hogere cholesterolgehalten in lagere SES bevolkingsgroepen gevonden $(6,10)$, terwijl twee Britse studies het tegenovergestelde resultaat lieten zien $(17,18)$. De weinige Nederlandse gegevens laten evenmin een eenduidige relatie zien tussen opleidingsniveau en cholesterolgehalte: bij mannen is er geen duidelijke trend, terwijl vrouwen met een hogere opleiding over het algemeen lagere cholesterolwaarden hebben dan vrouwen met een minder hoge opleiding (13).

De relatie tussen SES en alcoholgebruik is weinig eenduidig. In de Amerikaanse samenleving komt geheelonthouding veel vaker voor in lagere SES-groepen dan in hogere. De onderzoeksgegevens in nationale surveys in dat land zijn echter betrekkelijk inconsistent geweest met betrekking tot het verband tussen SES en zwaar alcoholgebruik en drankproblemen (19). In een andere Amerikaanse studie werden hogere prevalenties van zowel geheelonthouding als zwaar alcoholgebruik waargenomen onder de lager opgeleiden (20). In een recent Amerikaans onderzoek werd gevonden dat mannen uit hogere SES-groepen minder vaak geheelonthouders waren, minder vaak meer dan 3 glazen alcoholhoudende drank per dag nuttigden, minder vaak drankproblemen rapporteerden en minder vaak periodiek zware drinkers zijn dan mannen uit lagere SES-groepen (21). Overmatig alcoholgebruik was ook frequenter onder lager opgeleiden in een Canadese studie (22) en onder "blue-collar workers" in een Finse studie, zij het dat het laatste resultaat beperkt bleef tot de mannelijke populatie (23). 
In Nederland hebben hoger opgeleiden een iets hogere gemiddelde alcoholconsumptie dan lager opgeleiden. De verschillen bij mannen tussen deze groepen zijn tussen 1970 en 1980 echter kleiner geworden, terwijl ze bij vrouwen juist toegenomen lijken te zijn. Geheelonthouding komt in 1981 minder voor onder hoger opgeleiden, terwijl er zich onder de lager opgeleiden meer zware drinkers bevinden (meer dan 3 glazen per dag gemiddeld) (24). De resultaten wijzen in de richting van een iets hogere gemiddelde alcoholconsumptie onder de beter opgeleiden, terwijl overmatig drinken meer onder lager opgeleiden lijkt voor te komen.

Overgewicht zoals uitgedrukt in relatief gewicht $(=100$ maal de ratio van waargenomen gewicht en gewenst gewicht volgens lengte en geslacht-afhankelijke normtabellen) of de Queteletindex (gewicht/lengte ${ }^{2}$ ) vertoont weer een duidelijk negatief verband met SES-klasse. In twee van de drie epidemiologische studies in Chicago werd er een gradueel afnemend gemiddeld relatief gewicht gevonden bij toenemende opleidingsniveau's (15). Toenemende prevalentie van overgewicht in groepen met lagere opleidingsniveau's werd geobserveerd in een Noorse studie (10) en een Canadese studie (22).

In een Nederlandse studie bij jonge volwassenen (19-31 jaar) was er sprake van significante verschillen in gemiddelde Queteletindex tussen hoger, middelbaar, en lager opgeleide groepen, waarbij eenzelfde inverse trend werd geconstateerd (25). Afnemende Queteletindex bij stijgend opleidingsniveau werd eveneens gevonden in een recent gehouden bevolkingsonderzoek onder mannen en vrouwen tussen de 20 en 60 jaar in Amsterdam, Doetinchem en Maastricht (13). Tenslotte wees een ander Nederlands onderzoek uit dat bij zowel mannen als vrouwen het percentage mensen met overgewicht afliep van lagere sociale klasse tot hogere sociale klasse (26). Met andere woorden, al deze onderzoeksresultaten bevestigen een omgekeerd lineair verband tussen opleidingsniveau of SES en overgewicht, zowel in Nederland als in enkele andere geïndustrialiseerde landen.

\subsubsection{SES en morbiditeit en mortaliteit ten gevolge van ischemische hartziekten}

De belangrijkste doodsoorzaak in geīndustrialiseerde landen wordt gevormd door de groep van cardiovasculaire aandoeningen. Van alle sterfte aan deze groep aandoeningen kan weer ongeveer de helft toegeschreven worden aan de groep van ischemische hartziekten (IHZ). Vandaar dat hier apart ingegaan wordt op wat er bekend is over de relatie tussen SES-factoren en morbiditeit en mortaliteit ten gevolge van $\mathrm{IHZ}$. Aangezien er veel meer gegevens bekend zijn over de verdeling van $\mathrm{HHZ}$ mortaliteit dan over de verdeling van IHZ-morbiditeit over verschillende niveau's van SES, zal eerst op de eerste ingegaan worden.

De meeste onderzoeksgegevens met betrekking tot het verband tussen SES en IHZ-mortaliteit komen uit Groot-Brittannië en de Verenigde Staten. Verschillende Britse studies laten zien dat er een gradiënt bestaat tussen sociale klasse en sterfte aan 
IHZ: hoe hoger de sociale klasse des te lager de sterfte aan IHZ (27). Een analyse van Britse nationale censusgegevens liet zien dat het verschil in IHZ-mortaliteit tussen de hoogste en laagste sociale klassen van 1970-72 tot 1979-83 zelfs is toegenomen. Bedroeg de oversterfte begin jaren zeventig onder geschoolde en ongeschoolde mannelijke arbeiders tussen de 20 en 64 jaar nog ongeveer $12 \%$ in vergelijking met middelbare en hogere employees, begin jaren tachtig was dat verschil opgelopen tot ongeveer $30 \%$ (28). Hierbij moet opgemerkt worden dat wanneer deze moraliteitsverschillen gecorrigeerd worden voor de prevalentie van risicofactoren in deze groepen, de verschillen aanzienlijk, maar niet geheel, geneutraliseerd worden. Met name rookgedrag heeft een duidelijk aandeel in de oversterfte aan IHZ onder de geschoolde en ongeschoolde arbeiders (29). Het percentage rokers is in die beroepsgroepen tussen 1972 en 1982 ook veel minder sterk gedaald dan in de groep van middelbare en hogere employees (28). Voorts werd er in een studie van mannelijke Britse rijksambtenaren gevonden dat de groep van ambtenaren werkzaam in de hogere administratieve beroepen beduidend minder cardiale mortaliteit vertoonde dan de groepen ambtenaren werkzaam in de midden- of lagere kaders. De ambtenaren in de laagste beroepskaders hadden vier maal zoveel kans aan een hartziekte te overlijden dan degenen in het hoogste kader. Uit nadere analyse van deze gegevens bleek dat slechts $40 \%$ van deze oversterfte toegeschreven kon worden aan de klassieke risicofactoren roken, hoge bloeddruk en cholesterol (17).

In de Verenigde Staten bestaat er eveneens een verhoogde morbiditeit en mortaliteit aan IHZ bij lagere SES-groepen. Dit is vooral de laatste decennia zichtbaar geworden; daarvoor was er eerder sprake van oversterfte bij hogere SES-groepen (30). Dit is bijvoorbeeld aangetoond in een epidemiologisch onderzoek naar hartziekten in een agrarische streek in het zuiden van Amerika. In deze studie had een groep van blanke volwassen mannen afkomstig uit een hogere SES-klasse rond 1960 nog een verhoogd risico op IHZ-mortaliteit, terwijl een even oude groep mannen uit de lagere SES-klassen begin jaren zeventig het hoogste IHZ-sterfterisico had (31). In een studie van mannen die een eerste harinfarct overleefd hadden bleek dat mannen met een lagere opleiding een tweemaal zo hoge mortaliteit hadden dan mannen met een hogere opleiding, ook na correctie voor andere belangrijke prognostische factoren (32).

Er zijn eveneens enkele ecologische studies gedaan naar de relatie tussen indicatoren van SES en sterfte aan IHZ. Zo bleek in de staat Massachusetts dat in buurten die bewoond werden door mensen met doorgaans lage opleidingen, en die gekenmerkt werden door hoge percentages werkloosheid en slechte kwaliteit van huizen, een oversterfte aan IHZ voor te komen (33). Een recente Amerikaanse studie rapporteerde dat de daling van sterfte aan $\mathrm{IHZ}$ in de Verenigde Staten in de meeste gevallen later inzette in stedelijke gebieden gekenmerkt door lagere waarden op een aantal sociaal-economische indicatoren. Deze indicatoren bestonden bijvoorbeeld uit gemiddeld inkomen en gemiddelde opleiding en werkgelegenheid in een bepaald gebied, en toename of afname in deze factoren tussen 1960 en 1970. De gebieden met de 
minst gunstige sociaal-economische omstandigheden hadden 2 tot 10 maal zoveel kans dat de daling in IHZ-sterfte pas laat begon in vergelijking met gebieden met de gunstigste sociaal-economische omstandigheden (34).

Tot aan de jaren zeventig leverden de onderzoeksresultaten over het verband tussen SES-indicatoren en morbiditeit ten gevolge van $\Pi \mathrm{HZ}$ een weinig consistent beeld op. Er werden zowel positieve als negatieve associaties gevonden, terwijl er ook studies waren die geen enkel verband aantroffen tussen SES en incidentie van IHZ (33). Onder incidentie van IHZ wordt meestal nieuwe gevallen van angina pectoris en nieuwe gevallen van hartinfarct, zowel niet-fataal als fatale bedoeld. Jenkins concludeerde in 1971 op grond van de toen bekende onderzoeksresultaten dat er mogelijk een positief verband bestond tussen opleiding en risico voor angina pectoris, maar een negatief verband tussen opleiding en risico voor hartinfarct (34).

In latere studies is er vaker een duidelijke samenhang gevonden tussen SESfactoren en optreden van IHZ. De prevalentie van angina pectoris was in een recent Brits onderzoek tweemaal zo hoog onder geschoolde en ongeschoolde arbeiders als onder middelbare en hogere employees. Bij de eerstgenoemde groep werd ook $44 \%$ meer fatale en non-fatale hartinfarcten geconstateerd (29). In een recent Amerikaans onderzoek bleek dat de prevalentie van hartinfarcten een graduele relatie vertoonde met opleidingsniveau: het percentage mannen dat een hartinfarct had gehad was het hoogste in de groep die de minste opleiding gevolgd hadden, terwijl dat percentage afliep naarmate de groep een hogere opleiding voltooid had (35). In een Zweeds onderzoek naar cardiovasculaire ziekten bij vrouwen hadden degenen die alleen de lagere school afgemaakt hadden een significant verhoogd risico op angina pectoris, maar niet op een hartinfarct. Wel bleken vrouwen van echtgenoten die tot de groep van geschoolde of ongeschoolde arbeiders behoorden in vergelijking met vrouwen wier echtgenoten tot hogere beroepsgroepen behoorden, een grotere kans te hebben op fatale of niet fatale hartinfarcten (36). In een studie bij oudere mensen met systolische hypertensie was lage opleiding in univariate analyses significant geassocieerd met het optreden (incidentie) van de gecombineerde groep hartinfarct en plotselinge dood. Na correctie voor andere risicofactoren in multivariate analyses was dit verband evenwel niet meer significant (37).

$\mathrm{Er}$ is nagenoeg niets bekend over de relatie tussen sociaal-economische factoren en morbiditeit of mortaliteit ten gevolge van $\Pi \mathrm{HZ}$ in Nederland. Een recente studie naar mortaliteits-trends tussen 1969 en 1984 wees uit dat de sterfte aan IHZ in die periode sterker afnam in regio's met een hoger gemiddeld inkomen. Deze regio's kenden bij aanvang al een lagere sterfte aan IHZ dan regio's met een lager gemiddeld inkomen, met name in het noord-oosten en zuid-oosten van het land (38). Hoewel het hier om ecologische onderzoeksresultaten gaat, zijn deze bevindingen consistent met de mortaliteits-trend zoals die in Engeland en Wales zijn geobserveerd. 


\subsubsection{SES en totale mortaliteit en kankermortaliteit}

Sociaal-economische gezondheidsverschillen komen wellicht het best tot uitdrukking in de ongelijke sterftecijfers voor de verschillende SES-groepen. In vele geindustrialiseerde landen is inmiddels geconstateerd dat lagere SES-groepen benadeeld blijven met betrekking tot totale mortaliteit, ondanks de toegenomen verbeteringen in de gezondheidszorg (39).

In Engeland en Wales bestaan er sinds de jaren twintig statistieken over totale sterfte per beroepsklasse. Beroepsklasse in Engeland is onderverdeeld in 5 categorieën, waarbij de eerste categorie de "professionele" beroepsklasse voorstelt (bijv. arts, jurist) en de vijfde die van de ongeschoolde arbeiders (zie 11). Tussen 1920 en 1970 is er telkens een oversterfte geweest bij mannen en getrouwde vrouwen (vanaf 1930) uit de lagere beroepsklassen (categorieën IV en $\mathrm{V}$ ) in vergelijking met degenen uit de hogere beroepsklassen. Er was een duidelijke gradiënt aanwezig: iedere lagere beroepsklasse had telkens een hogere totale mortaliteit dan de daarop volgende beroepsklasse, rekening houdend met de verschillen in leeftijdsopbouw tussen de 5 beroepsklassen (zie 39). Net zoals dat het geval was bij cardiale mortaliteit is het verschil in totale mortaliteit bij mannen tussen de 20 en 64 jaar van 1970 tot begin jaren tachtig alleen maar groter geworden. De oversterfte bij geschoolde en ongeschoolde arbeiders in vergelijking met hogere beroepsklassen liep in die periode op van 30 tot $45 \%$ (28).

Van vele andere geïndustrialiseerde landen zijn geen soortgelijke nationale mortaliteitstrends per beroepsklasse over de laatste decennia bekend. Wel heeft onderzoek in bijvoorbeeld Finland, Nieuw-Zeeland en Australië eenzelfde omgekeerd verband opgeleverd tussen beroepsklasse en totale sterfte, zoals reeds in het WRR-rapport van vorig jaar is aangehaald (11). Ook landen als Frankrijk, Denemarken, Noorwegen (zie 11) en Japan (40) laten mortaliteitsverschillen zien tussen hogere en lagere beroepsklassen, die veel op de Engelse resultaten lijken. Tenslotte bleek ook in de Verenigde Staten mortaliteit samen te hangen met SES, waarbij de relatieve oversterfte weer met name aanwezig was bij lagere SES-groepen (41). Er is bijvoorbeeld een relatie gevonden tussen opleidingsniveau en totale sterfte, waarbij de laagst opgeleiden significant meer totale sterfte vertoonden dan hoger opgeleiden na correctie voor een aantal demografische factoren (42). In een bevolkingsonderzoek van bijna 11.000 deelnemers aan een hypertensie opsporings- en follow-up programma werd eveneens gevonden dat gedurende een vervolgperiode van 5 jaar de groep met een relatief lage schoolopleiding een significant hogere totale sterfte had dan de groep met een relatief hoge opleiding (43). In de eerder aangehaalde prospectieve studie van Zweedse vrouwen werd echter geen enkel verband tussen SES-factoren en totale mortaliteit gevonden (36). Het laatste toont aan dat de duidelijke oversterfte onder lagere SES-groepen wellicht niet voor alle geïndustrialiseerde landen geldt.

De samenhang tussen SES en kankersterfte zijn wederom het best aangetoond aan de hand van de Britse nationale gegevens. Gegevens uit 1970-1972 van mannen 
tussen 15 en 64 jaar laten zien dat sterfte aan kanker dezelfde gradiënt vertoont over de beroepsklassen als totale sterfte. Met andere woorden, de lagere beroepsklassen hebben een oversterfte aan kanker in vergelijking met hogere beroepsklassen. Dit verband geldt met name voor sterfte aan longkanker, de meest voorkomende vorm van kanker in deze populatie, terwijl er voor sommige andere vormen van kanker helemaal geen relatie lijkt te bestaan tussen beroepsklasse en sterfte (11). Uit een Amerikaans onderzoek uit de jaren zestig in Washington County, Maryland, werd duidelijk dat longkanker en lever- en galblaaskanker meer bij lager opgeleide SES-groepen voorkwam, hoewel dat effect niet significant kon worden aangetoond. Darmkanker- en pancreaskankersterfte waren daarentegen licht positief geassocieerd met opleidingsniveau. Andere vormen van kankersterfte hadden in deze studie geen enkel verband met opleidingsniveau (42). De oversterfte aan met name longkanker bij lagere SES-groepen is in overeenstemming met de incidentiegegevens: nieuwe gevallen van longkanker komen relatief veel vaker voor bij deze groepen dan bij hogere SES-groepen (zie bijv. 44). Deze relatie gaat voor andere vormen van kankersterfte lang niet altijd op.

In Nederland zijn er een aantal onderzoekingen geweest naar de relatie tussen SES-factoren en sterfte. Een van deze onderzoekingen is een studie naar inkomen en sterfte bij mannelijke Amsterdamse ambtenaren. Voor dit onderzoek zijn in 1953-54 gegevens over de loonschaal verzameld bij 1583 mannelijke ambtenaren in de leeftijd van 40 tot 65 jaar. De onderzoeksgroep werd onderverdeeld in 3 loonschaalcategorieën, en voor iedere categorie werd de totale sterfte 15 en 25 jaar later vastgesteld. Er werd geen verband gevonden tussen loonschaal en totale sterfte 15 of 25 jaar later. De totale sterfte was 25 jaar later weliswaar $10,1 \%$ lager in de hoogste inkomensgroep dan in de laagste, maar dit resultaat was niet statistisch significant (45). In een tweede studie werd de relatie tussen opleiding en sterfte geanalyseerd aan de hand van gegevens van bijna 80.000 18-jarige jongens, die in 1950 voor de militaire dienst werden onderzocht. Degenen met de hoogste opleiding (universitair) hadden een significant geringere sterftekans gedurende de follow-up periode, die tot en met 1981 duurde, dan degenen met alleen een lagere schoolopleiding. Het relatieve risico voor totale sterfte voor eerstgenoemde groep bedroeg 0,65 ( $95 \%$ betrouwbaarheidsinterval: $0,58-0,73$ ) in vergelijking met de laatstgenoemde groep (13).

Voorts zijn er een tweetal ecologische studies verricht naar de samenhang tussen SES en sterfte in Nederland. In het Vergelijkend Buurtonderzoek Amsterdam werden tussen 1972 en 1976 sterftecijfers berekend voor de 18 verschillende gebieden, waarin de stad was opgedeeld. Deze gebieden werden samengesteld op basis van een zo groot mogelijke sociaal-economische homogeniteit. De relatieve sociaal-economische status van ieder gebied werd vastgesteld aan de hand van inkomensniveau, beroepsniveau, onderwijsniveau en telefoonbezit. De voor leeftijd gecorrigeerde sterftecijfers per gebied gaven weer dat de gebieden die het laagst scoorden op de sociaaleconomische index duidelijk de hoogste sterfte vertoonden (46). Uit het eerder genoemde onderzoek van Mackenbach naar regionale gezondheidsverschillen in Neder- 
land bleek dat totale mortaliteit per regio ussen 1969 en 1984 meer gedaald was naarmate het gemiddeld inkomens- of opleidingsniveau in de desbetreffende regio in die periode meer gestegen was (38).

\subsubsection{Conclusie en vraagstelling}

Uit dit literatuuroverzicht blijkt dat er een redelijke hoeveelheid onderzoeksgegevens beschikbaar is met betrekking tot de samenhang tussen SES-factoren en risicofactoren voor hart- en vaatziekten. Het algemene beeld is dat deze risicofactoren over het algemeen in sterkere mate vóórkomen bij sociaal-economisch minder begunstigde groeperingen van de maatschappij. Deze relatie lijkt globaal op te gaan voor alle geindustrialiseerde landen, wanneer men althans de periode van de laatste 20 of 30 jaar beschouwt. Nederlandse onderzoeksbevindingen wijzen eveneens in deze richting. De enige uitzondering op de inverse relatie tussen SES en cardiovasculaire risicofactoren is alcoholgebruik, waarvoor geen duidelijke relatie met SES-factoren werd gevonden. Het kan evenwel zijn dat hogere SES-groepen een hogere gemiddelde alcoholconsumptie hebben terwijl zowel geheelonthouding als overmatig alcoholgebruik vaker voorkomen bij lagere SES-groepen.

Morbiditeit en mortaliteit ten gevolge van IHZ komt de laatste decennia net als de risicofactoren vaker voor bij lagere SES-groepen. De daling van de mortaliteit van deze groep ziekten, die zich sinds het midden of eind jaren zestig in een aantal geindustrialiseerde landen heeft ingezet, heeft eveneens het eerst plaatsgevonden bij groepen of gebieden met relatief gunstige SES-kenmerken. Valide gegevens over deze samenhang zijn echter schaars, en zijn vooral beperkt tot de zogenaamde "hard coronary events", dat wil zeggen: fatale en niet fatale hartinfarcten en/of plotselinge (cardiale) dood. Met betrekking tot de "soft coronary events", zoals angina pectoris of mogelijk infarct, is nagenoeg niets bekend. Dat laatste geldt zeker ook voor de Nederlandse situatie, waar er slechts spaarzame gegevens verzameld zijn met betrekking tot de relatie tussen SES-factoren en IHZ-morbiditeit en -mortaliteit.

Het verband tussen SES-factoren en totale sterfte vertoont hetzelfde ongunstige beeld voor de laagste SES-groepen. Daar komt oversterfte in vergelijking met bevolkingsgemiddelden of de sterfte van hogere SES groepen over het algemeen vaker voor. Zo'n relatie lijkt echter niet voor alle landen op te gaan, zoals bijvoorbeeld in Zweden het geval is (35). In Nederland is deze associatie nog vrijwel alleen op ecologisch niveau vastgesteld (38). Het militaire recrutenonderzoek toonde weliswaar een duidelijk negatief verband tussen opleiding en sterfte, doch hierbij was niet gecorrigeerd voor risicofactoren (13). Over het risico op kankersterfte valt niet veel te zeggen. Totale kankersterfte en sterfte aan longkanker bij mannen lijken dezelfde inverse gradiënt met SES-klasse te vertonen als totale sterfte, terwijl dat voor vele andere vormen van kankersterfte niet of zelfs het tegendeel opgaat. Over het risico op kankersterfte per SES-klasse in Nederland zijn geen gegevens bekend. 
Op basis van dit literatuuroverzicht zijn de volgende vragen onderzocht met behulp van het bestand van de Kaunas Rotterdam Intervention Study:

1. Wat is de relatie tussen SES-factoren en bepaalde gezondheidsrisico's? Deze relatie zal getoetst worden aan de hand van een aantal risicofactoren die vooral een rol spelen bij cardiovasculaire aandoeningen, met name roken, hoge bloeddruk, plasmacholesterolgehalte, alcoholgebruik en overgewicht.

2. Wat is de relatie tussen SES-factoren en risico voor ischemische hartziekte? Deze samenhang is onderzocht voor drie verschillende manifestaties van ischemische hartziekte. Dat zijn ten eerste de "soft events", gedefinieërd als het optreden van angina pectoris, mogelijk hartinfarct, en coronary artery bypass grafting surgery; ten tweede de "hard events", ofwel niet fatale en fatale hartinfarcten; en ten derde "total events", ofwel het optreden van zowel soft events als hard events.

3. Wat is de relatie tussen SES-factoren en sterfterisico? Hierbij is een onderscheid gemaakt tussen totaal sterfterisico en risico voor cardiale sterfte, gedefineerd als sterfte aan een fataal hartinfarct, en voor kankersterfte.

In het KRIS-bestand zijn tevens enige vragen opgenomen over gezondheidsopvattingen en houdingen tegenover artsen. Het werd belangrijk geacht om ook van deze subjectieve kenmerken de relaties met de SES-indicatoren vast te stellen. Vergelijking van deze subjectieve resultaten met de objectieve bevindingen kan bijdragen tot een beter begrip van sociaal-economische gezondheidsverschillen.

\subsection{METHODEN VAN ONDERZOEK}

\subsubsection{Inleiding}

Tussen 1972 en 1974 werd onder auspiciën van de WHO (World Health Organization) in Kaunas (Litouwen, Socialistische Sovjet Republiek) en Rotterdam een cardiovasculair screeningsprogramma gehouden. Het doel hiervan was de operationele aspecten van een interventiestudie in de algemene bevolking met verschillende systemen van gezondheidszorg te bestuderen. In Rotterdam participeerden 3365 mannen met een leeftijd van 45-59 jaar aan dit "feasibility"-onderzoek.

In 1982 werden voor dit KRIS-cohort via het Centraal Bureau voor Statistiek de diverse overlijdensoorzaken voor een follow-up van $91 / 2$ jaar verkregen. Verder werd in 1982 onder de nog in leven zijnde KRIS-deelnemers een morbiditeitsonderzoek gehouden waarmee de incidentie van cardiovasculaire eindpunten kon worden vastgesteld. Met behulp van deze gegevens kon in een prospectief ontwerp de relatie tussen sociaal-economische status en gezondheid worden bestudeerd.

ln de paragraaf 1.2.2 van dit hoofdstuk wordt de samenstelling van het KRIScohort en enkele aspecten van de dataverzameling beschreven. Met deze gegevens 
konden de samenhangen tussen sociaal-economische status enerzijds en gezondheidsopvattingen en cardiovasculaire risico-indicatoren anderzijds worden bestudeerd. De relevante vraagstellingen alsmede de operationalisaties van de gezondheidsopvattingen en de cardiovasculaire risico-indicatoren worden in paragraaf 1.2 .3 behandeld. In de paragraaf 1.2.4 komt het protocol van het follow-up onderzoek aan de orde. Verder worden in deze paragraaf de prospectieve vraagstellingen alsmede de operationalisaties van de gezondheidskenmerken gepresenteerd. Vervolgens worden opeenvolgend de operationele definities van sociaal-economische status en de statistische methoden aan de orde gesteld.

\subsubsection{Beschrijving van het onderzoekscohort}

In Rotterdam werden op grond van een "area sampling"-procedure 3882 mannen met een leeftijd van 45-59 jaar die verschillende sociaal-economische strata van een stadsbevolking representeerden voor het feasibility onderzoek benaderd. Voor de selectie van de te onderzoeken SES-gebieden werd gebruik gemaakt van een onderzoek van de Dienst voor Stadsontwikkeling naar sociale typologie van de buurten in Rotterdam (1963). In dit onderzoek is op basis van de volkstellingsgegevens van 1960 over beroep, opleiding en telefoonaansluiting voor elke buurt van Rotterdam een score voor de sociaal-economische status berekend. Op basis van deze score werden de buurten van Rotterdam in 4 categorieën ingedeeld: hoog, hoog-midden, laag-midden en laag. Deze typologie van buurten, waarvan de geldigheid in 1972 en 1977 nogmaals werd aangetoond, werd als uitgangspunt voor de steekproeftrekking genomen. Van elk van deze vier categorieën werd een representant uitgekozen. Voor de selectie van een representant binnen deze categorieën gold als voorwaarde een zo groot mogelijke homogeniteit van de buurt en een voldoende aantal mannen in de leeftujd van 45-59 jaar. Bovendien mocht het percentage buitenlanders, de migratiegraad sinds 1960 en de verdeling naar leeftijd, geslacht en gezinsgrootte niet te veel afwijken van de situatie voor Rotterdam als geheel. Elk van de vier aldus gekozen buurten werd verder onderverdeeld in subbuurten. Van een bepaalde aselect getrokken subbuurt werden alle mannen van 45 tot en met 59 jaar in de steekproef opgenomen. Vervolgens werden de mannen uit aangrenzende subbuurten benaderd. Er werden zoveel subbuurten gekozen tot een maximale steekproefomvang van 1000 personen per buurt was bereikt. In één buurt konden geen 1000 mannen van de gewenste leeftijdsgroep benaderd worden. Verder waren er vóór de eerste poging tot contact een aantal mannen overleden of verhuisd. De uiteindelijk benaderde groep bestond uit 3882 mannen.

Dit cohort werd in eerste instantie gevraagd om een zogenaamde "baseline"vragenlijst in te vullen. Deze bevatte vragen over onder andere de perceptie van de eigen gezondheidstoestand, houding ten aanzien van ziekte en ten aanzien van preventieve maatregelen, houding ten opzichte van arts en medische wereld, ervaringen met gezondheidszorginstanties en medische consumptie. Dit baseline onderzoek werd voor- 
afgaand aan het screeningsonderzoek uitgevoerd en was voomamelijk bedoeld om na te gaan of non-participatie aan de screening samenhing met bepaalde antwoorden op voornoemde vragen. Onafhankelijk van het al dan niet invullen van de baseline enquête werd iedereen van de steekproef voor het screeningsonderzoek uitgenodigd. Van de 3882 benaderde mannen participeerden 3365 (87\%) aan het screeningsonderzoek. De belangrijkste redenen voor non-participatie waren weigering of geen tijd/te druk. Gedurende de screening werden naast diverse medische kenmerken ook allerlei demografische, sociologische en psychologische eigenschappen vastgesteld. Belangrijke medische metingen betroffen bloeddruk, cholesterol, glucosetolerantie, ECG, antropometrische bepalingen, de ziekteanamnese van betrokkene zelf, de familieanamnese en de vaststelling van angina pectoris. Belangrijke niet-medische factoren waren opleiding en beroep van betrokkene, opleiding en beroep van partner en ouders, burgerlijke staat en rook- en drinkgewoonten.

Met de gegevens van de baseline-enquête en de screening konden diverse vraagstellingen met betrekking tot de uitvoerbaarheid van interventie in een open populatie worden beantwoord. Een uitvoerige beschrijving van de opzet van deze feasibility studie en van de belangrijkste uitkomsten zijn gerapporteerd in de jaargangen 19741978 van het Tijdschrift van Sociale Geneeskunde en in het boek: "The Kaunas Rotterdam Intervention Study" (3).

\subsubsection{Gezondheidsopvattingen en cardiovasculaire risicofactoren}

Als eerste is met behulp van de KRIS-gegevens onderzocht, of er samenhangen bestaan tussen sociaal-economische status en de opvattingen over gezond gedrag en de houding tegenover artsen. Deze opvattingen en meningen werden in het baseline onderzoek vastgelegd. Ter beantwoording van deze onderzoeksvraag werd een viertal van deze baseline vragen uitgekozen. De geselecteerde vragen hebben betrekking op respectievelijk de kansinschatting van de respondent dat iemand van zijn leeftijd de komende 5 tot 10 jaar een ernstige ziekte krijgt, de mening van de respondent omtrent de mogelijkheden om ziekte te voorkomen, de vergelijking van het belang van de eigen gezondheid met andere waardevolle dingen en de mate van het willen weten wat er in het geval van ziekte van de respondent met hem gedaan wordt. De exacte formulering van deze vier vragen alsmede de overeenkomstige categorieverdelingen staan in tabel 1.2.1 weergegeven.

Een volgende onderzoeksvraag richt zich op de mogelijke samenhang tussen sociaal-economische status en somatische en psychosociale risico-indicatoren van harten vaatziekten. De relevante risico-indicatoren zijn respectievelijk systolische en diastolische bloeddruk, plasmacholesterolgehalte, diabetes mellitus, Queteletindex, rookgewoonten, alcoholgebruik, burgerlijke staat en leeftijd. In tabel 1.2.2 staan de metingen van deze cardiovasculaire risicofactoren weergegeven. Uitgebreide informatie over de meting van de somatische risico-indicatoren, is weergegeven in Glasunov e.a. (3). 
Tijdens de screening werden eveneens diverse vragen naar rook- en drinkgewoonten gesteld. Met behulp van deze informatie konden de in tabel 1.2.2 weergegeven meetinstrumenten voor rookgedrag en alcoholconsumptie worden samengesteld. Voor een uitgebreide bespreking van de uiteindelijke totstandkoming van beide variabelen wordt verwezen naar de hoofdstukken 3 en 4.

Tabel 1.2.1 De baseline vragen betreffende gezondheidsopvattingen en houding tegenover dokter met de overeenkomstige catogorieverdelingen.

Is de kans, dat een gezonde man van Uw leeftijd in de komende vijf tot tien jaar de én of andere ernstige ziekte krijgt volgens $\mathrm{U}$ :

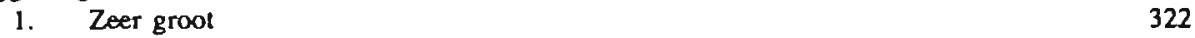

$\begin{array}{lr}\text { 2. Groot } & 1766\end{array}$

3. Niet groot $\quad 932$

(OPV1) (geen informatie)

De mensen bebben verschillende meningen over gezondheid en ziekte. Met welke van de volgende beweringen bent $U$ hel 't meest eens?

1. Je kunt er niets aan doen dat je ziek wordt $\quad 625$

2. In enkele gevallen kun je er iets an doen om ziekte te voorkomen 1552

3. Je kunt er veel aan doen om te voorkomen dat je ziek wordt 975

(OPV2) (geen informatie)

Gezondheid is een groot goed, maar hoe belangrijk vindt $U$ gezondheid vergeleken met andere wardevolle dingen? Welke van de volgende meningen komt het dichtst bij Uw eigen mening?

I. Gezondheid is het meest waardevolle dat er bestaat 2622

2. Er zijn andere dingen die mij even wardevol zijn als gezondheid 343

3. Ik leef liever prettig en wat korter, dan dat ik me bepaalde dingen ontzeg 184

(OPV3) (geen informatie)

Als U ziek bent, wilt U dan beslist weten wat er met U gedagn wordt?

1. Altijd

2. Soms

3. Zelden

4. Nooit 
Tabel 1.2.2 Metingen van somatische en psychosociale risico-indicatoren van hart- en vaatziekten voor 3365 KRIS-deelnemers

\begin{tabular}{|c|c|c|c|c|c|c|c|}
\hline Variabele & Symbool & Definitie & Freq. & Min. & Max. & Gem. & S.D. \\
\hline Roken & SMOKE & $\begin{array}{l}\text { 1. nooit gerookt } \\
\text { 2. ex-roker } \\
\text { 3. matige roker } \\
\text { 4. zware roker } \\
\text { (geen informatie) }\end{array}$ & $\begin{array}{r}244 \\
838 \\
546 \\
1719 \\
(18)\end{array}$ & & & & \\
\hline Alcohol & ALC & $\begin{array}{l}\text { 1. nooit drinker } \\
\text { 2. matige drinker } \\
\text { 3. zware drinker } \\
\text { (geen informatie) }\end{array}$ & $\begin{array}{r}291 \\
2528 \\
517 \\
(29)\end{array}$ & & & 2 & \\
\hline Diabetes mellitus & DIAB & $\begin{array}{l}\text { 1. geen diabetes } \\
\text { 2. wel diabetes } \\
\text { (geen informatie) }\end{array}$ & $\begin{array}{r}3299 \\
64 \\
(2) \\
\end{array}$ & & & & \\
\hline Queteletindex & QUET & $\begin{array}{l}\text { (gewicht/lengte }^{2} \text { ) } \\
\text { (geen informatie) }\end{array}$ & 14 & 16.7 & 47.9 & 25.5 & 3.0 \\
\hline $\begin{array}{l}\text { Systolische } \\
\text { bloeddruk }\end{array}$ & SBP & $\begin{array}{l}\mathrm{mm} \mathrm{Hg} \\
\text { (geen informatie) }\end{array}$ & (1) & 84 & 246 & 138 & 20 \\
\hline $\begin{array}{l}\text { Diastolische } \\
\text { bloeddruk }\end{array}$ & DBP & $\begin{array}{l}\mathrm{mm} \mathrm{Hg} \\
\text { (geen informatie) }\end{array}$ & (1) & 26 & 164 & 80 & 12 \\
\hline Cholestorol & $\mathrm{CHOL}$ & $\begin{array}{l}\mathrm{mg} / 100 \mathrm{ml} \text { plasma } \\
\text { (geen informatie) }\end{array}$ & (3) & 91 & 428 & 201 & 34 \\
\hline Leeftijd & AGE & $\begin{array}{l}\text { in jaren } \\
\text { (geen informatie) }\end{array}$ & $(0)$ & 44 & 60 & 52.5 & 4.3 \\
\hline Burgerlijke staat & BUST & $\begin{array}{l}\text { 1. gehuwd } \\
\text { 2. niet gehuwd } \\
\text { (geen informatie) }\end{array}$ & $\begin{array}{r}2944 \\
389 \\
(32)\end{array}$ & & & & \\
\hline
\end{tabular}

\subsubsection{Morbiditeit en mortaliteit tijdens Follow-up}

Zoals al werd uiteengezet, is de KRIS-studie nooit bedoeld geweest als een follow-up onderzoek naar de determinanten van hart- en vaatziekten. Een belangrijke consequentie hiervan is dat er geen herhalingsmetingen bij de oorspronkelijke participanten werden uitgevoerd. Omdat in Nederland weinig prospectief onderzoek naar hart- en vaatziekten is verricht, was het waardevol om alsnog na te gaan welke kenmerken, zoals gemeten bij screening, samenhangen met toekomstige cardiale morbiditeit en mortaliteit. Hiervoor werd in 1982 naast de vaststelling van de diverse overlijdensoorzaken via het Centraal Bureau voor Statistiek, een additioneel cardiovasculair morbiditeitsonderzoek onder de nog in leven zijnde KRIS-deelnemers gehouden. Deze 
KRIS-deelnemers, die volgens de gemeenteadministratie van hun woonplaats nog in leven waren, kregen een uitgebreide vragenlijst over hartklachten toegezonden ten einde te achterhalen of men in de afgelopen 10 jaar een hartinfarct, CVA of angina pectoris had doorgemaakt (Appendix 1). Wanneer de antwoorden ook maar de geringste aanwijzing voor een eventueel doorgemaakte coronaire aandoening bevatten, werd er contact met de betrokken huisarts gezocht. Voor diegenen waarvoor de betreffende huisarts geen of onvoldoende informatie kon verstrekken en voor diegenen met een poliklinische of klinische ziekenhuiservaring werd de behandelende specialist geraadpleegd.

In tabel 1.2.3 wordt de database van de follow-up studie gepresenteerd. Van de oorspronkelijke screeningsparticipanten bleek $10 \%$ overleden. Van de overlevenden participeerde $91 \%$ aan de morbiditeits-enquête. Een substudie waarbij 30 non-respondenten zijn vergeleken met de respondenten, leerde dat de non-respons niet samenhing met het al dan niet hebben van een hartziekte. Het wordt daarom waarschijnlijk geacht dat de "targetpopulation" goed gerepresenteerd wordt door de "respondent population" (47).

Tabel 1.2.3 De data-base van de KRIS Follow-up studie

\begin{tabular}{|l|r|r|}
\hline & $\mathrm{N}$ & $\%$ \\
\hline Non participanten & 232 & 7 \\
Adres niet te achterbalen & 52 & 2 \\
Overleden & 350 & 10 \\
Respondenten hartklachtenlijst & 2731 & 81 \\
\hline & 3365 & 100 \\
\hline
\end{tabular}

De cardiale morbiditeit werd vastgesteld door middel van een coderingssysteem, waarin rekening gehouden kon worden met de al dan niet volledigheid van de beschikbare informatie. Deze codering berust op de via de behandelend arts verkregen gegevens over anamnese, electrocardiogram en enzymen ten tijde van het cardiovasculaire accident. Deze gegevens werden bijna steeds overgenomen uit de ontslagbrieven van de specialisten. In appendix 2 is dit coderingssysteem weergegeven. Op basis van het mortaliteitsonderzoek alsmede het morbiditeitsonderzoek kunnen de KRISparticipanten in de, in tabel 1.2.4 weergegeven, groepen worden ingedeeld.

De tabel laat zien dat 114 mannen aan kanker en 112 mannen ten gevolge van een hartinfarct zijn overleden. Verder hebben 126 mannen een, als waarschijnlijk of zeker geklassificeerd, non-fataal hartinfarct gehad. Gedurende de $91 / 2$ jaar follow-up hebben 106 mannen een zogenaamde "zachte" cardiovasculaire gebeurtenis (angina pectoris of een bypass operatie of een mogelijk non-fataal hartinfarct) doorgemaakt. Vermeld moet worden dat een ieder die ten gevolge van een hartinfarct is overleden in 
een eerder stadium een of meer non-fatale hartinfarcten kan hebben gehad. Deze informatie ontbreekt.

Tabel 1.2.4 Indeling van KRIS-participanten na 9 1/2 jaar follow-up

\begin{tabular}{|l|r|r|}
\hline & $\mathrm{N}$ & $\%$ \\
\hline non-respondenten morbiditeitsenquête & 232 & 7 \\
adres niet te achterhalen & 52 & 2 \\
onbekende doodsoorzaak & 23 & 1 \\
sterfte ten gevolge van kanker & 114 & 3 \\
fataal hartinfarct & 112 & 3 \\
non-cardiale/non-carcinogene sterfte & 101 & 3 \\
mogelijk non-fataal hartinfarct & 31 & 1 \\
angina pectoris & 126 & 3 \\
bypass operatie & 54 & 2 \\
geen hartlijden tijdens follow-up & 21 & 1 \\
& 2499 & 74 \\
\hline
\end{tabular}

Met behulp van de KRIS follow-up gegevens kon onderzocht worden of sociaal-economische status na correctie voor relevante cardiovasculaire risicofactoren gerelateerd is aan de gezondheid, uitgedrukt in termen van toekomstige hart- en vaatziekten. De relevante cardiovasculaire risicofactoren zijn diastolische bloeddruk, cholesterol, diabetes mellitus, Queteletindex, roken, alcoholgebruik, burgerlijke staat en leeftijd. Er wordt in dit onderzoek een onderscheid in 3 typen van cardiovasculaire eindpunten gemaakt, te weten: incidentie van "soft events", incidentie van "hard events" en incidentie van alle coronaire aandoeningen. Bij deze vraagstelling is het noodzakelijk om die deelnemers, waarbij ten tijde van de screening al een hartlijden werd gesignaleerd, van verdere analyse uit te sluiten. De uitsluitingscriteria waren:

- Angina pectoris zoals vastgesteld met behulp van de vragenlijst van Rose.

- ECG afwijkingen die zeker of mogelijk op een doorgemaakt infarct wijzen, i.c. Minnesotacode I.1.2.3, IV.1.2.3. of VII.1.

Vanwege het eerste criterium konden 147 deelnemers en vanwege het tweede criterium 309 deelnemers niet in de follow-up analyses worden opgenomen. Tabel 1.2.5 toont de uiteindelijke dataset, waarop de follow-up analyses van hart- en vaatziekten werden gebaseerd.

Behalve de uitsluiting van diegenen met een cardiovasculaire voorgeschiedenis, werden apart voor elke analyse van de drie verschillende vormen van hart- en vaatziekten relevante "concurrerende" follow-up eindpunten weggelaten. Dit heeft de volgende consequentie voor de operationalisatie van deze drie typen hart- en vaatziekten: Als non-cases werden voor elk cardiaal eindpunt telkens die 2251 mannen genomen die ten tijde van de screening gezond waren en gedurende de $9^{1 / 2}$ jaar follow-up gezond 
bleven; als cases werden respectievelijk 71 opgetreden "soft events", 163 opgetreden "hard events" en alle 234 opgetreden coronaire aandoeningen genomen.

Tabel 1.2.5 Dataset voor de follow-up analyse van hart-en vaataandoeningen

\begin{tabular}{|l|r|r|}
\hline & $\mathrm{N}$ & $\boldsymbol{Z}$ \\
\hline coronaire aandoening tijdens screening & 456 & 14 \\
non-respondenten morbiditeitsenquête & 206 & 6 \\
adres niet te achterhalen & 46 & 1 \\
onbekende doodscorzaak & 16 & 0 \\
non-cardiale sterfte & 156 & 5 \\
fataal bartinfarct & 69 & 2 \\
non-fataal hartinfarct (mogelijk) & 25 & 1 \\
non-fataal hartinfarct (wasschijnlijk/zeker) & 94 & 3 \\
angina/bypass (zonder infarct) & 46 & 1 \\
geen coronair lijden tijdens follow up & 2251 & 67 \\
\hline & 3365 & 100 \\
\hline
\end{tabular}

In de onderstaande tabel wordt de getalsmatige samenstelling van deze aantallen getoond.

cases $\mathrm{N}$

$\begin{array}{llc}\text { "soft events" } & 46+25 & 71 \\ \text { "hard events" } & 69+94 & 163 \\ \text { "all events" } & 46+25+69+94 & 234\end{array}$

Zoals de tabel aangeefi, is het aantal opgetreden "soft events" de som van 46 angina/bypass gevallen en 25 mogelijke non-fatale hartinfarcten. Het aantal opgetreden "hard events" is de som van 69 fatale hartinfarcten en 94 (waarschijnlijk of zekere) non-fatale hartinfarcten. De som van de opgetreden "soft events" $(46+25)$ en de opgetreden "hard events" $(69+94)$ levert tenslotte het totale aantal opgetreden coronaire aandoeningen.

Vervolgens werd onderzocht of sociaal-economische status na correctie voor relevante risico-indicatoren gerelateerd is aan de gezondheid wanneer deze in termen van sterfte-oorzaken wordt uitgedrukt. In dit onderzoek wordt een onderscheid gemaakt in totale sterfte, sterfte ten gevolge van kanker en cardiale sterfte. Als relevante risico-indicatoren voor totale sterfte en kankersterfte werden roken, alcoholgebruik, burgerlijke staat en leeftijd genomen. Voor cardiale sterfte werden hieraan nog diastolische bloeddruk, cholesterol, Queteletindex en diabetes mellitus toegevoegd. Op cardiale sterfte zijn dezelfde exclusiecriteria als op de drie eerder genoemde typen van hart- en vaatziekten van toepassing. De afhankelijke variabele cardiale sterfte wordt derhalve door 69 fatale hartinfarcten en 2251 "gezonde" overlevenden uitgedrukt. Tabel 1.2.4 laat zien dat er 350 mannen ten gevolge van alle oorzaken zijn overleden. 
Van diegenen, die de morbiditeitsenquête niet hebben beantwoord en van diegenen van wie het adres niet meer was te achterhalen, is in elk geval bekend dat ze ten tijde van het morbiditeits- en mortaliteitsonderzoek nog in leven waren. De afhankelijke variabele totale sterfte wordt daarom door 350 sterftegevallen en 3015 overlevenden uitgedrukt. Bij de analyses op kankersterfte werden de "concurrerende" eindpunten fataal hartinfarct, non-cardiale/non-carcinogene sterfte en onbekende doodsoorzaak van analyse uitgesloten. Tabel 1.2.4 laat zien dat de afhankelijke variabele kankersterfte dan door 114 sterftegevallen ten gevolge van kanker en 3015 overlevenden wordt uitgedrukt.

\subsubsection{Operationalisatie van sociaal-economische status}

Het concept sociaal-economische status werd in deze studie op verschillende wijze geoperationaliseerd:

1) Als het opleidingsniveau van de respondent

2) Als het beroepsniveau van de respondent zoals dat op het moment van screenen is vastgelegd

3) Als het type SES-wijk waarin de respondent woont

4) Als een SES-index.

Tabel 1.2.6 Oorspronkelijke en gehercodeerde operationalisaties van opleidingsniveau

\begin{tabular}{|c|c|c|c|}
\hline Oorspronkelijk & $N$ & Hercodering & $\mathbf{N}$ \\
\hline $\begin{array}{l}\text { 1. LO of VGLO/LAVO of enige jaren ULO/MAVO zonder meer } \\
\text { 2. LO of VGLO/LAVO of enige jaren ULO/MAVO plus speci- } \\
\text { fieke partime opleiding }\end{array}$ & $\begin{array}{r}1318 \\
227\end{array}$ & $\begin{array}{l}\text { Lager onderwijs } \\
\text { (1) }\end{array}$ & 1545 \\
\hline $\begin{array}{l}\text { 3. Diploma lager beroepsonderwijs of primair huishoudschool } \\
\text { zonder meer } \\
\text { 4. Diploma lager beroepsonderwijs of primair huishoudschool } \\
\text { plus specifieke partime opleiding }\end{array}$ & 401 & $\begin{array}{l}\text { Lager } \\
\text { beroepsonderwijs } \\
\text { (2) }\end{array}$ & 743 \\
\hline $\begin{array}{l}\text { 5. Diploma ULO/MAVO of enige jaren VHMO zonder meer } \\
\text { 6. Diploma ULO/MAVO of enige jaren VHMO plus specifieke } \\
\text { partime opleiding } \\
\text { 7. Diploma VHMO of middelbaar beroepsonderwijs }\end{array}$ & $\begin{array}{l}153 \\
216 \\
287\end{array}$ & $\begin{array}{l}\text { Middelbaar } \\
\text { onderwijs (3) }\end{array}$ & 656 \\
\hline $\begin{array}{l}\text { 8. Diploma hoger beroepsonderwijs } \\
\text { 9. Diploma universiteit of hogeschool }\end{array}$ & $\begin{array}{l}184 \\
170\end{array}$ & $\begin{array}{l}\text { HBO/Universiteit } \\
\text { (4) }\end{array}$ & 345 \\
\hline Geen informatie & 67 & & 67 \\
\hline TOTAAL & 3365 & & 3365 \\
\hline
\end{tabular}


ad 1) Tabel 1.2.6 toont zowel de oorspronkelijke als de in het onderzoek gehanteerde meting van opleidingsniveau. In de oorspronkelijke screeningsmeting werd opleidingsniveau in negen categorieën vastgelegd. In de analyses wordt deze variabele als nominaal beschouwd. Terwille van de verlaging van het aantal vrijheidsgraden werden de oorspronkelijke categorieẽn tot een kleiner aantal gehercategoriseerd.

ad 2) Tabel 1.2.7 toont zowel de oorspronkelijke als de gehanteerde categorieënindeling van beroepsniveau. Aangezien beroepsniveau in de analyses eveneens als een nominale variabele wordt beschouwd, werden ter verlaging van het aantal vrijheidsgraden een aantal oorspronkelijke categorieën samengevoegd. De tabel laat zien dat van 5 mannen geen beroepsniveau kan worden bepaald. Omdat met een dergelijk klein aantal geen berekeningen kunnen worden uitgevoerd, werden deze mannen niet in de analyses opgenomen. De oorspronkelijke beroepenindeling is gebaseerd op de door het Instituut voor Toegepaste Sociologie ontwikkelde Beroepenklapper (48).

Tabel 1.2.7 Oorspronkelijke en gehercodeerde indeling van beroepsniveau

\begin{tabular}{|l|r|l|r|}
\hline Oorspronkelijk & N & Hercodering & N \\
\hline 1. Ongeschoolde arbeid & 352 & Arbeider (1) & 1565 \\
2. Geschoolde arbeid & 1213 & & 1271 \\
\hline 3. Lagere employees & 625 & Employee (2) & \\
4. Kleine zelfstandigen & 292 & & 472 \\
5. Middelbare employees & 354 & & \\
\hline 6. Hogere beroepen & 472 & Hoger beroep (3) & 57 \\
\hline 7. Geen beroep & 5 & & 3365 \\
\hline Geen informatie & 52 & & \\
\hline TOTAAL & 3365 & & \\
\hline
\end{tabular}

Tabel 1.2.8 De gehanteerde metingen van SES-wijk en SES-index voor 3365 KRIS-deelnemers

\begin{tabular}{|l|l|l|l|l|l|l|l|}
\hline Var. & Sym. & Definitie & Freq. & Min. & Max. & Gem. & S.D. \\
\hline SES-wijk & QUAR & $\begin{array}{l}\text { 1. Laag } \\
\text { 2. Laag-midden } \\
\text { 3. Hoog-midden } \\
\text { 4. Hoog }\end{array}$ & $\begin{array}{l}741 \\
870\end{array}$ & & & & \\
932 & 822 & & & & \\
\hline $\begin{array}{l}\text { SES- } \\
\text { index }\end{array}$ & SCAL & $\begin{array}{l}\text { schaalmetingen in gehele getallen } \\
\text { logaritmische schaalpunten in } \\
\text { rezle getallen } \\
\text { (geen informatie) }\end{array}$ & & -9 & 29 & 0 & 10 \\
\hline
\end{tabular}


ad 3) De ecologische factor SES-wijk werd op grond van de eerder beschreven area sampling procedure verkregen. Dit bood de mogelijkheid om de variabele wijk als een contextuele SES-indicator in het onderzoek mee te nemen. De frequentieverdeling van SES-wijk wordt in tabel 1.2 .8 gepresenteerd.

ad 4) De SES-index werd met behulp van de kenmerken opleidingsniveau, beroepsniveau, SES-wijk alsmede het initieel beroepsniveau (dit is het beroep dat de respondent na het afsluiten van de opleiding voor het eerst uitoefende) en het beroepsniveau van de vader geconstrueerd. De schaalconstructie werd, met behulp van een non-lineair "scalings"-programma (HOMALS) en factor-analyse uitgevoerd. Op basis van deze technieken kon een SES-index (SCAL) worden geconstrueerd zoals die in tabel 1.2.8 omschreven wordt. De minimum score -9 duidt op een lage sociaal-economische status en de maximum score 29 op een hoge sociaal-economische status. De details van deze schaalconstructie worden in appendix 4 besproken.

\subsubsection{Statistische methoden}

\section{Gezondheidsopvattingen}

De (mogelijke) samenhangen van de SES-variabelen opleiding, beroep en SESwijk met de in tabel 1.2.1 gepresenteerde gezondheidsopvattingen werden met behulp van log-frequentie-analyse voor tweedimensionele kruistabellen vastgesteld. Omdat zowel de SES-indicatoren als de diverse gezondheidsopvattingen multipele categorische variabelen zijn, is de interpretatie van een eventueel geconstateerde statistisch significante samenhang niet altijd eenvoudig aangezien niet zonder meer duidelijk is welke categorieëncombinaties nu specifiek voor deze significantie verantwoordelijk zijn. Het log-frequentiemodel biedt de mogelijkheid om hier inzicht in te verkrijgen. Bij log-frequentie analyse worden (de parameters van) alle categorieëncombinaties getoetst op statistische significantie. Om de invloed van het toeval op de vele statistische toetsingen enigszins uit te schakelen wordt het lage significantieniveau van .01 gehanteerd (tweezijdige toetsing). Toch wordt benadrukt dat bij de presentatie van de analyseresultaten (in paragraaf 3 ) de veelvuldig gebezigde term "significant" veel meer in descriptieve dan in toetsende betekenis opgevat moet worden. Voor een uitgebreidere bespreking van het log-frequentiemodel wordt verwezen naar appendix 3.

De mogelijke relaties tussen de geconstrueerde SES-index en de vier gezondheidsopvattingen werden met behulp van eenwegvariantie-analyses vastgesteld. Bij deze analyse is de SES-index de afhankelijke variabele en de vier gezondheidsopvattingen zijn afzonderlijk de onafhankelijke variabelen. Met een F-statistic wordt getoetst of een of meer categorie-gemiddelden van een gezondheidsopvatting statistisch significant verschillen van het algemene SES-gemiddelde. Bij significantie van de toetsingsgrootheid is er sprake van een samenhang tussen SES-index en een gezondheidsopvatting. 
Een belangrijke assumptie van variantie-analyse is dat de afhankelijke variabele bij benadering normaal verdeeld moet zijn. Tabel 1.2.8 laat zien dat de standaarddeviatie van SES-index (SCAL) groter is dan de "range" tussen gemiddelde en minimumwaarde. Dit betekent dat de variabele SES-index zeer scheef verdeeld is. Ter verkrijging van een benadering van de normale verdeling teneinde de variantie-analyses mogelijk te maken, werd de SES-index logaritmisch getransformeerd (LSCAL = 5 log [SCAL $+11]$ ). De verdeling van de logaritmisch getransformeerde schaalpunten (LSCAL) staat eveneens in tabel 1.2.8 weergegeven. Bij de analyses ter vaststelling van de relaties tussen SES-variabelen en gezondheidsopvattingen werden alle 3365 KRIS-deelnemers betrokken.

\section{Risico-indicatoren}

De tweede onderzoeksvraag richt zich op de mogelijke samenhang tussen SES en somatische en psychosociale risico-indicatoren van hart- en vaatziekten. De mogelijke samenhangen van de SES-variabelen opleiding, beroep en SES-wijk met de in tabel 1.2.2 getoonde categorische variabelen roken, alcoholgebruik, diabetes mellitus en burgerlijke staat werden met behulp van log-frequentie-analyse vastgesteld. Ter vaststelling van de relaties tussen bovengenoemde categorische risico-indicatoren èn de (logaritmisch getransformeerde) SES-index werden eenwegvariantie-analyses uitgevoerd. De associatie tussen de drie categorische SES-indicatoren en de continue variabelen systolische en diastolische bloeddruk, cholesterol, Queteletindex en leeftijd werd met eenwegvariantie-analyse bestudeerd. Voor de vaststelling van mogelijke associaties tussen deze risico-indicatoren èn de SES-index werden Pearson produktmoment correlaties berekend. Alle univariate analyses werden wederom met behulp van de gegevens van alle 3365 KRIS-deelnemers uitgevoerd.

\section{Hart- en vaatziekten}

De derde onderzoeksvraag heeft betrekking op de voor relevante cardiovasculaire risicofactoren gecorrigeerde (mogelijke) relatie tussen sociaal-economische status en "soft events", "hard events" en alle coronaire aandoeningen. De voor diastolische bloeddruk, cholesterol, Queteletindex, diabetes mellitus, roken, alcoholgebruik, leefuijd en burgerlijke staat gecorrigeerde effecten van de vier SES-indicatoren op de genoemde dichotome afhankelijke gezondheidsvariabelen werden met behulp van logistische regressie-analyse berekend. In het logistische regressiemodel kunnen zowel multipele categorische variabelen als continue variabelen als onafhankelijke predictoren worden opgenomen. In de analyses werden voor de categorische SES-indicatoren opleiding, beroep en SES-wijk als referentiecategorie respectievelijk de mannen met HBO/Universiteit, hoger beroep en hoogste SES-wijk genomen. Dit geschiedde omdat apriori vermoed werd dat het aantal cardiovasculaire aandoeningen in deze groepen het kleinst 
zou zijn. De geconstrueerde SES-index daarentegen werd als continue variabele aan de gezondheid gerelateerd. In appendix 5 wordt het logistische regressiemodel nader toegelicht.

\section{Mortaliteit}

De vierde onderzoeksvraag richt zich op de voor relevante risicofactoren gecorrigeerde relatie tussen sociaal-economische status en gezondheid uitgedrukt in termen van totale sterfte, kankersterfte en cardiale sterfte. De voor roken, alcoholgebruik, leeftijd en burgerlijke staat gecorrigeerde effecten van de vier SES-indicatoren op de dichotome afhankelijke variabelen kankersterfte en totale sterfte werden met Cox regressie-analyse bepaald. Ook de voor de somatische (cardiovasculaire) risico-indicatoren alsmede roken, alcoholgebruik, leeftijd en burgerlijke staat gecorrigeerde effecten van de vier SES-indicatoren op cardiale sterfte werden met behulp van Cox regressie-analyse berekend. Omdat Cox regressie ook de tijd totdat er al dan niet een bepaalde gebeurtenis optreedt in het model verdisconteert, verdient deze procedure vanwege betrouwbaardere parameterschattingen de voorkeur boven logistische regressie waar alleen van de cumulatieve incidentie wordt uitgegaan. Cox regressie-analyse kon echter alleen op de drie sterftevariabelen worden toegepast omdat alleen van deze eindpunten de datering bekend is.

De log-lineaire analyses, de variantie-analyses en de Pearson-correlaties werden met het standaardpakket SPSSX (49) uitgevoerd. De diverse Cox en logistische regressie-analyses werden uitgevoerd met respectievelijk de $2 L$ en de $L R$ procedure van het BMDP-pakket (50). Voor een uitgebreidere bespreking van het Cox model wordt verwezen naar appendix 5 .

\subsection{ONDERZOEKSRESULTATEN}

\subsubsection{De relatie tussen SES en gezondheidsopvattingen}

In deze paragraaf worden de analyseresultaten met betrekking tot de relaties tussen SES en opvattingen over gezondheid en houding tegenover dokters gepresenteerd. Uit de likelihoodratiotesten bleek dat alle vier baseline vragen statistisch significant samenhingen met de genoemde SES-indicatoren.

Zoals blijkt uit tabel 1.3 .1 bestaat er een significant verschil tussen de drie beroepstrata met betrekking tot de schatting van de kans dat men binnen 5 tot 10 jaar een emstige ziekte krijgt. Arbeiders schatten deze kans het hoogst in. Ook employees achten deze kans vaker zeer groot. Mannen met een hoger beroep achten deze kans vaker niet zeer groot. De tabel toont tevens dat er ook voor opleidingsniveau significante verschillen met betrekking tot deze kansinschatting bestaan. De lager opgeleiden 
(LO en LBO) schatten de kans dat men binnen 5 tot 10 jaar een emstige ziekte krijgt het hoogst in. Daarentegen beschouwen HBO-ers of academici deze kans vaker als niet zeer groot.

Tabel 1.3.1 De kansinschatting van de respondent dat iemand van ajn leeftijd de komende 5 tot 10 jaar een ernstige ziekte krijgt naar categorieèn van respectievelijk beroep, opleiding en SES-wijk. In het bovenste gedeelte staan de absolute frequenties; daaronder de $\boldsymbol{Z}$-orde parameterschattingen met in de randmarginalen de hoofdeffecten alsmede het algemeen gemiddelde. * duidt op significantie $(p<.01)$

\begin{tabular}{|c|c|c|c|c|}
\hline & zeer grote kans & grote kans & niet grote kans & \\
\hline $\begin{array}{l}\text { arbeider } \\
\text { employee } \\
\text { hoger beroep }\end{array}$ & $\begin{array}{r}186 \\
116 \\
16\end{array}$ & $\begin{array}{l}815 \\
687 \\
252 \\
\end{array}$ & $\begin{array}{l}415 \\
351 \\
160 \\
\end{array}$ & \\
\hline $\begin{array}{l}\text { arbeider } \\
\text { employee } \\
\text { boger beroep }\end{array}$ & $\begin{array}{l}.38^{*} \\
.17^{*} \\
-.55^{*} \\
\end{array}$ & $\begin{array}{l}-.15^{*} \\
-.05 \\
.20^{*}\end{array}$ & $\begin{array}{l}-.23^{*} \\
-.12^{*} \\
.35^{*}\end{array}$ & $\begin{array}{r}.60 \\
.33 \\
-.93\end{array}$ \\
\hline $\begin{array}{l}\text { chi }^{2}=40.85 \\
p=.00\end{array}$ & -1.14 & .87 & .27 & 5.38 \\
\hline $\begin{array}{l}\text { LO } \\
\text { LBO } \\
\text { MO } \\
\text { HBO/universiteit }\end{array}$ & $\begin{array}{r}176 \\
74 \\
54 \\
9\end{array}$ & $\begin{array}{l}784 \\
423 \\
357 \\
187\end{array}$ & $\begin{array}{l}417 \\
193 \\
188 \\
127\end{array}$ & \\
\hline $\begin{array}{l}\text { LO } \\
\text { LBO } \\
\text { MO } \\
\text { HBO/universiteit }\end{array}$ & $\begin{array}{l}.37^{*} \\
.26^{*} \\
.11 \\
-.74^{*}\end{array}$ & $\begin{array}{l}-.18^{*} \\
-.04 \\
-.04 \\
.26^{*}\end{array}$ & $\begin{array}{l}-.19^{*} \\
-.22^{*} \\
-.07 \\
.48^{*}\end{array}$ & $\begin{array}{l}.88 \\
.13 \\
-.04 \\
-.97\end{array}$ \\
\hline $\begin{array}{l}\mathrm{chi}^{2}=44.32 \\
\mathrm{p}=.00\end{array}$ & -1.16 & .88 & .28 & 5.08 \\
\hline $\begin{array}{l}\text { lage wijk } \\
\text { laag-midden } \\
\text { hoog-midden } \\
\text { hoge wijk }\end{array}$ & $\begin{array}{r}90 \\
108 \\
90 \\
34\end{array}$ & $\begin{array}{l}334 \\
459 \\
537 \\
436\end{array}$ & $\begin{array}{l}211 \\
216 \\
235 \\
270\end{array}$ & \\
\hline $\begin{array}{l}\text { lage wijk } \\
\text { laag-midden } \\
\text { hoog-midden } \\
\text { hoge wijk }\end{array}$ & $\begin{array}{l}.25^{*} \\
.26^{*} \\
.06 \\
. .57^{*}\end{array}$ & $\begin{array}{l}-.21^{*} \\
-.07^{*} \\
.07 \\
.21^{*}\end{array}$ & $\begin{array}{l}-.04 \\
-.19^{*} \\
-.13^{*} \\
.36\end{array}$ & $\begin{array}{r}-.05 \\
.12 \\
.14 \\
-.21\end{array}$ \\
\hline $\begin{array}{l}\mathrm{chi}^{2}=66.72 \\
\mathrm{p}=.00\end{array}$ & -.10 & .80 & -.70 & 4.40 \\
\hline
\end{tabular}

Uit tabel 1.3.1 blijkt verder dat de bewoners van de vier SES-wijken eveneens significant verschillen met betrekking tot deze kansinschatting. Mannen die in de lage 
en in de laag-midden SES-wijk wonen achten deze kans vaker zeer groot. De bewoners van de hoge SES-wijk achten daarentegen deze kans vaker niet zeer groot.

Tabel 1.3.2 De meningen over gezondheid en ziekte naar categorieën van beroep, opleiding en SESwijk

\begin{tabular}{|c|c|c|c|c|}
\hline & $\begin{array}{l}\text { Niets te doen aan } \\
\text { ziek worden }\end{array}$ & $\begin{array}{l}\text { Soms is ziekte } \\
\text { te voorkomen }\end{array}$ & $\begin{array}{l}\text { Veel aan te doen } \\
\text { om ziekte te voor- } \\
\text { komen }\end{array}$ & \\
\hline $\begin{array}{l}\text { arbeider } \\
\text { employee } \\
\text { hoger beroep }\end{array}$ & $\begin{array}{r}407 \\
190 \\
21 \\
\end{array}$ & $\begin{array}{l}684 \\
627 \\
231 \\
\end{array}$ & $\begin{array}{l}385 \\
387 \\
194 \\
\end{array}$ & \\
\hline $\begin{array}{l}\text { arbeider } \\
\text { employee } \\
\text { hoger beroep }\end{array}$ & $\begin{array}{r}.62^{*} \\
.14^{*} \\
-.76^{*} \\
\end{array}$ & $\begin{array}{l}-.23^{*} \\
-.03 \\
.26^{*} \\
\end{array}$ & $\begin{array}{r}-.39^{*} \\
-.11^{*} \\
.50^{*} \\
\end{array}$ & $\begin{array}{r}.62 \\
.34 \\
-.96 \\
\end{array}$ \\
\hline $\begin{array}{l}\mathrm{chi}^{2}=45.48 \\
p=.00\end{array}$ & .78 & .59 & .19 & 5.55 \\
\hline $\begin{array}{l}\text { LO } \\
\text { LBO } \\
\text { MO } \\
\text { HBO/universiteit }\end{array}$ & $\begin{array}{r}427 \\
137 \\
40 \\
15\end{array}$ & $\begin{array}{l}650 \\
377 \\
322 \\
174 \\
\end{array}$ & $\begin{array}{l}367 \\
201 \\
251 \\
145\end{array}$ & \\
\hline $\begin{array}{l}\text { LO } \\
\text { LBO } \\
\text { MO } \\
\text { HBO/universiteit }\end{array}$ & $\begin{array}{l}.77^{*} \\
.40^{*} \\
-.46^{*} \\
-.71^{*}\end{array}$ & $\begin{array}{l}-.31^{*} \\
-.09 \\
.16^{*} \\
.24^{*} \\
\end{array}$ & $\begin{array}{r}-.46^{*} \\
-.31^{*} \\
.30^{*} \\
.47^{*} \\
\end{array}$ & $\begin{array}{r}.94 \\
.18 \\
-.20 \\
-.92 \\
\end{array}$ \\
\hline $\begin{array}{l}\mathrm{chi}^{2}=51.17 \\
\mathrm{p}=.00\end{array}$ & -.86 & .64 & .22 & 5.31 \\
\hline $\begin{array}{l}\text { lage wijk } \\
\text { lagg-midden } \\
\text { hoog-midden } \\
\text { hoge wijk }\end{array}$ & $\begin{array}{r}186 \\
205 \\
185 \\
49 \\
\end{array}$ & $\begin{array}{l}308 \\
385 \\
439 \\
420 \\
\end{array}$ & $\begin{array}{l}176 \\
229 \\
271 \\
299 \\
\end{array}$ & \\
\hline $\begin{array}{l}\text { lage wijk } \\
\text { laag-midden } \\
\text { hoog-midden } \\
\text { hoge wijk }\end{array}$ & $\begin{array}{l}.38^{*} \\
.29^{*} \\
.12^{*} \\
-.79^{*} \\
\end{array}$ & $\begin{array}{l}-.15^{*} \\
-.12^{*} \\
-.06 \\
.33^{*}\end{array}$ & $\begin{array}{l}-.23^{*} \\
-.17^{*} \\
-.06 \\
.46^{*}\end{array}$ & $\begin{array}{r}-.07 \\
.12 \\
.19 \\
-.24 \\
\end{array}$ \\
\hline $\begin{array}{l}c h i^{2}=47.93 \\
p=.00\end{array}$ & -.53 & .50 & .03 & 5.44 \\
\hline
\end{tabular}

In tabel 1.3.2 staan de $2^{\mathrm{e}}$-orde parameterschattingen van beroepsniveau, opleidingsniveau en SES-wijk met betrekking tot de meningen over gezondheid en ziekte. De tabel laat zien dat de drie beroepstrata significant in deze meningen verschillen. Arbeiders huldigen het vaakst de opvatting dat er niets te doen is aan ziekte. Hoewel in 
mindere mate dan arbeiders zijn employees eveneens vaker de mening toegedaan dat er niets te doen is aan ziek worden. De hogere beroepen uiten vaker een ander standpunt. $\mathrm{Zij}$ zijn het vaakst van mening dat er veel aan te doen is om ziekte te voorkomen.

De significante verschillen in opleidingsniveau en in SES-wijk met betrekking tot de meningen over gezondheid en ziekte zijn praktisch analoog aan de resultaten van beroepsniveau. Tabel 1.3.2 laat zien dat de lager opgeleiden (LO en LBO) vaker de mening zijn toegedaan dat er niets te doen is aan ziek worden. De hoger opgeleiden (MO en HBO/universiteit) huldigen daarentegen vaker de opvatting dat er veel te doen is om ziekte te voorkomen. Bewoners van respectievelijk de lage, de laag-midden en de hoog-midden SES-wijk zijn, overeenkomstig deze volgorde in afnemende mate, vaker de mening toegedaan dat er niets te doen is aan ziek worden. Daarentegen zijn de bewoners van de hoge SES-wijk het vaakst van mening dat er veel aan te doen is om ziekten te voorkomen.

Tabel 1.3.3 geeft een overzicht van de $2^{\mathrm{e}}$-orde parameterschattingen van beroepsniveau, opleidingsniveau en SES-wijk met de waardering van gezondheid. De tabel laat zien dat arbeiders en mannen met hogere beroepen significant verschillen met betrekking tot deze gezondheidswaardering. Arbeiders zijn het vaakst van mening dat gezondheid het meest waardevol is. De hogere beroepen beschouwen daarentegen het vaakst andere dingen even belangrijk als gezondheid. Er blijken geen verschillen tussen de drie beroepsgroepen te bestaan met betrekking tot een voorkeur voor een prettig en wat korter leven.

De significante verschillen in opleidingsniveau en in SES-wijk met betrekking tot de gezondheidswaardering zijn iets diffuser als bij beroepsniveau. De tabel laat zien dat de lager opgeleiden ( $\mathrm{LO}$ en LBO) het vaakst gezondheid als het meest waardevolle achten. De LO-groep valt hierbij echter enigszins uit de toon. Ze zijn de enigen die tevens vaker aangeven liever prettig en wat korter te leven. De HBO-ers en academici onderscheiden zich door het vaakst aan te geven dat andere dingen even belangrijk als gezondheid zijn.

Tabel 1.3.3 toont verder dat bewoners van de lage SES-wijk het vaakst gezondheid als het meest waardevol beschouwen. De bewoners van de laag-midden SES-wijk worden alleen gekenmerkt door andere dingen minder vaak even belangrijk als gezondheid te achten. De bewoners van de hoog-midden SES-wijk waarderen weer vaker de gezondheid als het meest waardevol. Daarentegen waarderen bewoners van de hoge SES-wijk als enigen het vaakst andere dingen even belangrijk als gezondheid.

Tabel 1.3.4 toont de $2^{\mathrm{e}}$-orde parameter schattingen van beroepsniveau, opleidingsniveau en SES-wijk met de mate waarin men wil weten wat een medische behandeling behelst. Uit de tabel kan worden afgeleid dat alleen arbeiders en mannen die een hoger beroep uitoefenen significant verschillen met betrekking tot het willen weten wat een medische behandeling inhoudt. Arbeiders geven het minst vaak aan altijd te willen weten wat er bij ziekte met hen gedaan wordt, terwijl mannen die een hoger beroep uitoefenen het vaakst aangeven altijd te willen weten wat een medische behan- 
deling inhoudt. Er blijken geen verschillen tussen de beroepsgroepen te bestaan met betrekking tot het soms en nooit willen weten wat een medische behandeling behelst.

Tabel 1.3.3 De vergelijking van gezondheid met andere waardevolle dingen naar categorieën van beroep, opleiding en SES-wijk

\begin{tabular}{|c|c|c|c|c|}
\hline & $\begin{array}{l}\text { gezondheid meest } \\
\text { waardevol }\end{array}$ & $\begin{array}{l}\text { andere dingen even } \\
\text { belangrijk als } \\
\text { gezondheid }\end{array}$ & $\begin{array}{l}\text { liever prettig en } \\
\text { korter leven }\end{array}$ & \\
\hline $\begin{array}{l}\text { arbeider } \\
\text { employee } \\
\text { hoger beroep }\end{array}$ & $\begin{array}{r}1304 \\
1003 \\
293 \\
\end{array}$ & $\begin{array}{r}93 \\
131 \\
116 \\
\end{array}$ & $\begin{array}{l}79 \\
71 \\
33 \\
\end{array}$ & \\
\hline $\begin{array}{l}\text { arbeider } \\
\text { employee } \\
\text { hoger beroep }\end{array}$ & $\begin{array}{l}.34^{*} \\
.09 \\
-.43^{*} \\
\end{array}$ & $\begin{array}{l}-.42^{*} \\
-.08 \\
.50^{*} \\
\end{array}$ & $\begin{array}{l}.08 \\
-.01 \\
-.07 \\
\end{array}$ & $\begin{array}{r}.24 \\
.23 \\
-.47 \\
\end{array}$ \\
\hline $\begin{array}{l}\mathrm{chi}^{2}=125.44 \\
\mathrm{p}=. \infty 0\end{array}$ & 1.47 & -.40 & -1.07 & 5.12 \\
\hline $\begin{array}{l}\text { LO } \\
\text { LBO } \\
\text { MO } \\
\text { HBO/universiteit }\end{array}$ & $\begin{array}{r}1238 \\
626 \\
486 \\
199 \\
\end{array}$ & $\begin{array}{r}80 \\
56 \\
95 \\
106 \\
\end{array}$ & $\begin{array}{l}86 \\
33 \\
39 \\
24 \\
\end{array}$ & \\
\hline $\begin{array}{l}\text { LO } \\
\text { LBO } \\
\text { MO } \\
\text { HBO/universiteit }\end{array}$ & $\begin{array}{l}.35^{*} \\
.31^{*} \\
-.09 \\
-.57^{*} \\
\end{array}$ & $\begin{array}{l}-.56^{*} \\
-.24^{*} \\
.14 \\
.66^{*}\end{array}$ & $\begin{array}{l}.21^{*} \\
-.07 \\
-.05 \\
-.09\end{array}$ & $\begin{array}{r}.54 \\
-.14 \\
.01 \\
-.41 \\
\end{array}$ \\
\hline $\begin{array}{l}\mathrm{chi}^{2}=187.34 \\
p=.00\end{array}$ & 1.48 & -.38 & -1.10 & 4.79 \\
\hline $\begin{array}{l}\text { lage wijk } \\
\text { lang-midden } \\
\text { hoog-midden } \\
\text { hoge wijk }\end{array}$ & $\begin{array}{l}590 \\
708 \\
774 \\
550\end{array}$ & $\begin{array}{r}39 \\
59 \\
83 \\
162 \\
\end{array}$ & $\begin{array}{l}41 \\
53 \\
39 \\
51 \\
\end{array}$ & \\
\hline $\begin{array}{l}\text { lage wijk } \\
\text { laag-midden } \\
\text { hoog-midden } \\
\text { hoge wijk }\end{array}$ & $\begin{array}{l}.19^{*} \\
.09 \\
.13^{*} \\
-.41^{*}\end{array}$ & $\begin{array}{l}-.36^{*} \\
-.23^{*} \\
.06 \\
.53^{*}\end{array}$ & $\begin{array}{l}.17 \\
.14 \\
-.19 * \\
-.12\end{array}$ & $\begin{array}{r}-.28 \\
.00 \\
.04 \\
.24 \\
\end{array}$ \\
\hline $\begin{array}{l}\mathrm{chi}^{2}=112.56 \\
\mathrm{p}=.00\end{array}$ & 1.61 & -.56 & -1.05 & 4.86 \\
\hline
\end{tabular}

De beantwoordingspatronen van opleidingsniveau en type SES-wijk vertonen een grote overeenkomst met die van beroepsniveau. Tabel 1.3.4 laat zien dat de lager opgeleiden ( $\mathrm{LO}$ en $\mathrm{LBO}$ ) het vaakst zelden en de hoger opgeleiden (HBO/universiteit) het vaakst altijd willen weten wat een medische behandeling inhoudt. Voor de catego- 
rieën soms en nooit blijkt er geen verschil in opleidingsniveau te bestaan. Tevens toont de tabel dat respectievelijk de bewoners van de lage, de laag-midden en de hoog-midden SES-wijk minder vaak altijd willen weten wat een medische behandeling inhoudt terwijl de bewoners van de hoge SES-wijk als enigen het vaakst aangeven dit wel te willen weten. Behalve de hoog-midden SES-wijk blijken de overige wijken niet te verschillen met betrekking tot het soms en nooit willen weten wat een medische behandeling behelst.

Tabel 1.3.4 De vragg "wilt U weten wat er bij ziekte met U gedaan wordt" naar categorieèn van beroep, opleiding en SES-wijk

\begin{tabular}{|c|c|c|c|c|c|}
\hline & altijd & soms & zelden & nooit & \\
\hline $\begin{array}{l}\text { arbeider } \\
\text { employee } \\
\text { boger beroep }\end{array}$ & $\begin{array}{l}883 \\
798 \\
347 \\
\end{array}$ & $\begin{array}{r}361 \\
259 \\
62 \\
\end{array}$ & $\begin{array}{r}83 \\
50 \\
7\end{array}$ & $\begin{array}{r}138 \\
90 \\
27\end{array}$ & \\
\hline $\begin{array}{l}\text { arbeider } \\
\text { employex } \\
\text { boger beroep }\end{array}$ & $\begin{array}{l}-.34 * \\
-.09 \\
.43 *\end{array}$ & $\begin{array}{r}.02 \\
.03 \\
-.05 \\
\end{array}$ & $\begin{array}{l}.31 * \\
.15 \\
-.46^{*} \\
\end{array}$ & $\begin{array}{r}.01 \\
-.09 \\
-.08 \\
\end{array}$ & $\begin{array}{r}.68 \\
.34 \\
-1.02 \\
\end{array}$ \\
\hline $\begin{array}{l}\mathrm{chi}^{2}=57.80 \\
\mathrm{p}=.00\end{array}$ & 1.61 & .37 & -1.40 & -.58 & 4.83 \\
\hline $\begin{array}{l}\text { LO } \\
\text { LBO } \\
\text { MO } \\
\text { HBO/universiteit }\end{array}$ & $\begin{array}{l}863 \\
444 \\
441 \\
268 \\
\end{array}$ & $\begin{array}{r}346 \\
176 \\
114 \\
47 \\
\end{array}$ & $\begin{array}{r}89 \\
28 \\
20 \\
3\end{array}$ & $\begin{array}{r}143 \\
57 \\
41 \\
15 \\
\end{array}$ & \\
\hline $\begin{array}{l}\text { LO } \\
\text { LBO } \\
\text { MO } \\
\text { HBO/universiteit }\end{array}$ & $\begin{array}{l}-.42^{*} \\
-.23^{*} \\
.04 \\
.61^{*}\end{array}$ & $\begin{array}{r}-.10 \\
.08 \\
-.08 \\
.10\end{array}$ & $\begin{array}{l}.46^{*} \\
.16 \\
.10 \\
-.72^{*}\end{array}$ & $\begin{array}{r}.06 \\
-.01 \\
-.06 \\
.01\end{array}$ & $\begin{array}{r}1.05 \\
.19 \\
-.08 \\
-1.16\end{array}$ \\
\hline $\begin{array}{l}\mathrm{chi}^{2}=80.09 \\
\mathrm{p}=.00\end{array}$ & 1.66 & .43 & -1.49 & -.60 & 4.47 \\
\hline $\begin{array}{l}\text { lage wijk } \\
\text { laag-midden } \\
\text { hoog-midden } \\
\text { hoge wijk }\end{array}$ & $\begin{array}{l}431 \\
463 \\
558 \\
594 \\
\end{array}$ & $\begin{array}{l}141 \\
220 \\
216 \\
111 \\
\end{array}$ & $\begin{array}{r}34 \\
50 \\
47 \\
9 \\
\end{array}$ & $\begin{array}{l}59 \\
83 \\
64 \\
51\end{array}$ & \\
\hline $\begin{array}{l}\text { lage wijk } \\
\text { laag-midden } \\
\text { hoog-midden } \\
\text { hoge wijk }\end{array}$ & $\begin{array}{l}-.10 \\
-.34 * \\
-.12 * \\
.56\end{array}$ & $\begin{array}{r}-.10 \\
.03 \\
.05 \\
.02\end{array}$ & $\begin{array}{l}.21 \\
.29^{*} \\
.26^{*} \\
-.76^{*}\end{array}$ & $\begin{array}{l}-.01 \\
.02 \\
-.19 * \\
.18\end{array}$ & $\begin{array}{r}-.06 \\
.25 \\
.21 \\
. .40\end{array}$ \\
\hline $\begin{array}{l}c h i^{2}=100.39 \\
p=.00\end{array}$ & 1.51 & .39 & -1.34 & -.56 & 4.72 \\
\hline
\end{tabular}


In tabel 1.3.5 worden de resultaten van de eenwegvariantie-analyses van de logaritmisch getransformeerde SES-index met de vier baseline-vragen gepresenteerd. De tabel laat zien dat elke baselinevraag statistisch significant samenhangt met de SESindex. De richting van deze samenhangen wordt door de eveneens gepresenteerde groepsgemiddelden aangegeven.

Tabel 1.3.5 Eenwegvariantie-analyses met de getransformeerde SES-index als afhankelijke en vier baseline vragen (OPV1, OPV2, OPV3, HOUD1) als onafhankelijken

\begin{tabular}{|l|c|c|c|c|c|l|}
\hline & $\mathrm{N}$ & $\mathrm{gem}$. & $\begin{array}{c}\text { gem. } \\
\text { SSB (df) }\end{array}$ & $\begin{array}{c}\text { gem. } \\
\text { SSW (df) }\end{array}$ & $\mathrm{F}$ & $\mathrm{P}$ \\
\hline OPV1: & & & & & & \\
zeer grote kans & 297 & 3.83 & & & & \\
grote kans & 1673 & 4.45 & 61.15 & 3.32 & 18.40 & .00 \\
niet grote kans & 889 & 4.55 & $(2)$ & $(2856)$ & & \\
\hline OPV2: & & & & & & \\
niets te doen aan zekte & 578 & 3.43 & & & & \\
soms is ziekte te voorkomen & 1466 & 4.54 & 367.53 & 3.12 & 118.33 & .00 \\
veel te doen ziekte te voorkomen & 936 & 4.82 & $(2)$ & $(2977)$ & & \\
\hline OPV3: & & & & & & \\
gezondheid meest waardevol & 2482 & 4.25 & & & & \\
andere dingen even belangrijk & 321 & 5.60 & 261.80 & 3.16 & 82.77 & .00 \\
liever prettig en korter leven & 174 & 4.58 & $(2)$ & $(2974)$ & & \\
\hline HOUD1: & & & & & & \\
altijd & 1934 & 4.61 & & & & \\
soms & 650 & 4.12 & 74.91 & 3.28 & 22.80 & .00 \\
zelden & 133 & 3.81 & $(3)$ & $(2955)$ & & \\
nooit & 242 & 3.98 & & & & \\
\hline
\end{tabular}

Zo heeft de groep die de kans op een emstige ziekte als zeer groot beschouwd gemiddeld de laagste sociaal-economische status (3.83). Daarentegen hebben diegenen die de kans op een emstige ziekte als niet groot beschouwen gemiddeld de hoogste sociaaleconomische status (4.55). Ook de groep die van mening is dat er niets te doen is om een ziekte te voorkomen heeft gemiddeld de laagste sociaal-economische status (3.43), terwijl degenen die de mening zijn toegedaan dat er veel te doen is om ziekte te voorkomen gemiddeld de hoogste sociaal-economische status hebben (4.82). Zowel degenen die de gezondheid als het meest waardevolle waarderen als de groep die antwoordt liever prettig en wat korter te leven dan zich bepaalde dingen te ontzeggen worden beide door een lagere sociaal-economische status gekenmerkt (de gemiddelden zijn respectievelijk 4.25 en 4.58). Daarentegen hebben mannen waarvoor andere dingen even waardevol als de gezondheid zijn gemiddeld de hoogste sociaal-economische status (5.60). Tenslotte blijkt uit de tabel dat de groep van mannen die altijd willen 
weten wat er bij ziekte met hen gedaan wordt gemiddeld de hoogste sociaal-economische status heeft (4.61). Mannen die zelden willen weten wat er bij ziekte met hen gedaan wordt, hebben gemiddeld de laagste sociaal-economische status (3.81).

\subsubsection{De relatie tussen SES en cardiovasculaire risico-indicatoren}

In deze paragraaf komen de resultaten met betrekking tot de relaties tussen SES en somatische en psychosociale risico-indicatoren van hart- en vaatziekten aan de orde. Uit de likelihoodratio-testen bleek dat diabetes niet significant gerelateerd is aan de vier SES-indicatoren. Daarentegen bleken roken, alcoholgebruik en burgerlijke staat wel significant met deze SES-indicatoren samen te hangen. De celfrequenties en de $2^{\mathrm{e}}$ orde interactieparameters van de significante relaties met beroepsniveau, opleidingsniveau en SES-wijk staan in de tabellen $1.3 .6 \mathrm{t} / \mathrm{m} 1.3 .8$ weergegeven.

Tabel 1.3.6 laat zien dat er een significant verschil tussen arbeiders en mannen met hogere beroepen bestaat met betrekking tot rookgedrag. Arbeiders zijn minder vaak nooit-rokers of ex-rokers en vaker zware rokers. Mannen met een hoger beroep zijn daarentegen vaker nooit-rokers of ex-rokers en minder vaak zware rokers.

De tabel toont verder dat er ook voor opleidingsniveau significante verschillen met betrekking tot rookgedrag bestaan. De lager opgeleiden (LO en LBO) blijken vaker zware rokers te zijn, terwijl de hoger opgeleiden (MO en $\mathrm{HBO} /$ universiteit) minder vaak zwaar roken. LO-ers zijn bovendien minder vaak nooit rokers of ex-rokers, terwijl HBO-ers of academici juist aangeven vaker nooit te hebben gerookt of gestopt te zijn met roken.

Eenzelfde patroon is ook bij de SES-wijk waar te nemen. Wat betreft de categorie zwaar roken, laat tabel 1.3.6 zien dat bewoners van respectievelijk de lage, de laagmidden en de hoog-midden SES-wijk, overeenkomstig deze volgorde in afnemende mate, vaker zware rokers blijken te zijn. Bewoners van de hoge SES-wijk zijn het minst vaak zware rokers.

In tabel 1.3.7 staan de $2^{\mathrm{e}}$-orde parameterschattingen van beroepsniveau, opleidingsniveau en SES-wijk naar categorieēn van alcoholconsumptie. De tabel laat zien dat arbeiders en mannen met een hoger beroep significant verschillen met betrekking tot alcoholgebruik. Arbeiders zijn het vaakst nooit drinkers en het minst vaak matige drinkers, terwijl mannen met een hoger beroep het vaakst matig drinken en het minst vaak nooit drinken.

De significante verschillen in opleidingsniveau met betrekking tot alcoholconsumptie zijn praktisch analoog aan die van beroepsniveau. Tabel 1.3.7 toont dat de lager opgeleiden (LO en LBO) minder vaak matig drinken, terwijl de hoger opgeleiden (HBO/universiteit) juist het vaakst matig drinken. Voor de categorie zwaar drinken werden er geen verschillen in opleidingsniveau gevonden.

Ook de significante verschillen in type SES-wijk met betrekking tot alcoholconsumptie corresponderen in hoge mate met die van beroep en opleiding. Bewoners van de lage 
en de laag-midden SES-wijk zijn minder vaak matige drinkers, terwijl de bewoners van de hoge SES-wijk het vaakst matig en zwaar drinken.

Tabel 1.3.6 De resultaten van log-frequentie-analyse van roken naar categorieën van beroep, opleiding en SES-wijk

\begin{tabular}{|c|c|c|c|c|c|}
\hline & nooit gerookt & ex-roker & matige roker & zware roker & \\
\hline $\begin{array}{l}\text { arbeider } \\
\text { employee } \\
\text { hoger beroep }\end{array}$ & $\begin{array}{l}79 \\
97 \\
56\end{array}$ & $\begin{array}{l}307 \\
352 \\
168 \\
\end{array}$ & $\begin{array}{r}244 \\
201 \\
98 \\
\end{array}$ & $\begin{array}{l}934 \\
619 \\
149 \\
\end{array}$ & \\
\hline $\begin{array}{l}\text { arbeider } \\
\text { employee } \\
\text { boger beroep }\end{array}$ & $\begin{array}{l}-.28^{*} \\
.01 \\
.29^{*} \\
\end{array}$ & $\begin{array}{l}-.17^{*} \\
.03 \\
.14^{*} \\
\end{array}$ & $\begin{array}{l}.04 \\
-.09 \\
.05\end{array}$ & $\begin{array}{l}.41^{*} \\
.07 \\
-.48^{*} \\
\end{array}$ & $\begin{array}{r}.33 \\
.26 \\
-.59 \\
\end{array}$ \\
\hline $\begin{array}{l}\mathrm{chi}^{2}=134.76 \\
\mathrm{p}=.00\end{array}$ & -.96 & .29 & -.15 & .82 & 5.28 \\
\hline $\begin{array}{l}\text { LO } \\
\text { LBO } \\
\text { MO } \\
\text { HBO/universiteit }\end{array}$ & $\begin{array}{l}88 \\
44 \\
60 \\
42\end{array}$ & $\begin{array}{l}305 \\
183 \\
212 \\
127\end{array}$ & $\begin{array}{r}232 \\
111 \\
125 \\
72\end{array}$ & $\begin{array}{l}920 \\
403 \\
258 \\
112 \\
\end{array}$ & \\
\hline $\begin{array}{l}\text { LO } \\
\text { LBO } \\
\text { MO } \\
\text { HBO/universiteit }\end{array}$ & $\begin{array}{l}-.19^{*} \\
-.19 \\
.09 \\
.29^{*}\end{array}$ & $\begin{array}{l}-.21^{*} \\
-.02 \\
.09 \\
.14^{*}\end{array}$ & $\begin{array}{r}-.01 \\
-.06 \\
.03 \\
.04 \\
\end{array}$ & $\begin{array}{l}.41^{*} \\
.27^{*} \\
-.21^{*} \\
-.47^{*} \\
\end{array}$ & $\begin{array}{l}.64 \\
-.05 \\
-.02 \\
-.57\end{array}$ \\
\hline $\begin{array}{l}\mathrm{chi}^{2}=145.36 \\
\mathrm{p}=.00\end{array}$ & -.95 & .31 & -.16 & .80 & 4.98 \\
\hline $\begin{array}{l}\text { lage wijk } \\
\text { laag-midden } \\
\text { hoog-midden } \\
\text { hoge wijk }\end{array}$ & $\begin{array}{l}56 \\
46 \\
52 \\
90\end{array}$ & $\begin{array}{l}125 \\
175 \\
250 \\
288\end{array}$ & $\begin{array}{l}100 \\
158 \\
128 \\
160\end{array}$ & $\begin{array}{l}452 \\
468 \\
498 \\
283 \\
\end{array}$ & \\
\hline $\begin{array}{l}\text { lage wijk } \\
\text { lang-midden } \\
\text { hoog-midden } \\
\text { hoge wijk }\end{array}$ & $\begin{array}{l}.13 \\
-.23^{*} \\
-.18 \\
.28^{*}\end{array}$ & $\begin{array}{l}-.28^{*} \\
-.11 \\
.17^{*} \\
.22^{*}\end{array}$ & $\begin{array}{l}-.11 \\
.18 * \\
-.10 \\
.03\end{array}$ & $\begin{array}{l}.26^{*} \\
.16^{*} \\
.11^{*} \\
. .53^{*}\end{array}$ & $\begin{array}{r}-.18 \\
-.02 \\
.06 \\
.14\end{array}$ \\
\hline $\begin{array}{l}\mathrm{chi}^{2}=167.09 \\
\mathrm{p}=.00\end{array}$ & -1.00 & .22 & -.18 & .96 & 5.07 \\
\hline
\end{tabular}


Tabel 1.3.7 De resultaten van log-frequentie-aralyse van alcoholgebruik naar categorieën van beroep, opleiding en SES-wijk

\begin{tabular}{|c|c|c|c|c|}
\hline & nooit drinker & matige drinker & zware drinker & \\
\hline $\begin{array}{l}\text { arbeider } \\
\text { employee } \\
\text { hoger beroep }\end{array}$ & $\begin{array}{r}168 \\
96 \\
18 \\
\end{array}$ & $\begin{array}{r}1137 \\
972 \\
392 \\
\end{array}$ & $\begin{array}{r}250 \\
198 \\
62 \\
\end{array}$ & \\
\hline $\begin{array}{l}\text { arbeider } \\
\text { employee } \\
\text { hoger beroep }\end{array}$ & $\begin{array}{l}.30^{*} \\
.06 \\
-.36 * \\
\end{array}$ & $\begin{array}{l}-.22^{*} \\
-.06 \\
.28^{*}\end{array}$ & $\begin{array}{r}-.08 \\
.00 \\
.08 \\
\end{array}$ & $\begin{array}{r}.63 \\
.31 \\
-.94 \\
\end{array}$ \\
\hline $\begin{array}{l}\mathrm{chi}^{2}=32.56 \\
\mathrm{p}=.00\end{array}$ & -1.07 & 1.36 & -.29 & 5.26 \\
\hline $\begin{array}{l}\text { LO } \\
\text { LBO } \\
\text { MO } \\
\text { HBO/universiteit }\end{array}$ & $\begin{array}{r}153 \\
69 \\
42 \\
17 \\
\end{array}$ & $\begin{array}{r}1119 \\
560 \\
520 \\
295 \\
\end{array}$ & $\begin{array}{r}246 \\
110 \\
92 \\
42 \\
\end{array}$ & \\
\hline $\begin{array}{l}\text { LO } \\
\text { LBO } \\
\text { MO } \\
\text { HBO/universiteit }\end{array}$ & $\begin{array}{l}.17^{*} \\
.16 \\
-.09 \\
-.24^{*}\end{array}$ & $\begin{array}{l}-.21^{*} \\
-.11^{*} \\
.07 \\
.25^{*}\end{array}$ & $\begin{array}{l}.04 \\
-.05 \\
-.02 \\
-.01 \\
\end{array}$ & $\begin{array}{l}.90 \\
.12 \\
-.13 \\
-.89 \\
\end{array}$ \\
\hline $\begin{array}{l}\mathrm{chi}^{2}=27.22 \\
p=.00\end{array}$ & -1.01 & 1.30 & -.29 & 4.97 \\
\hline $\begin{array}{l}\text { lage wijk } \\
\text { lasg-midden } \\
\text { boog-midden } \\
\text { hoge wijk }\end{array}$ & $\begin{array}{l}88 \\
83 \\
96 \\
24 \\
\end{array}$ & $\begin{array}{l}497 \\
631 \\
717 \\
683 \\
\end{array}$ & $\begin{array}{l}145 \\
147 \\
113 \\
112\end{array}$ & 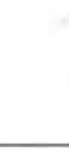 \\
\hline $\begin{array}{l}\text { lage wijk } \\
\text { lasg-midden } \\
\text { hoog-midden } \\
\text { hoge wijk }\end{array}$ & $\begin{array}{l}.25^{*} \\
.12 \\
.27^{\star} \\
-.64^{*} \\
\end{array}$ & $\begin{array}{l}-.30^{*} \\
-.13^{*} \\
.00 \\
.43^{*}\end{array}$ & $\begin{array}{l}.05 \\
.01 \\
-.27^{*} \\
.21^{*}\end{array}$ & $\begin{array}{l}.07 \\
.13 \\
.14 \\
-.34 \\
\end{array}$ \\
\hline $\begin{array}{l}\mathrm{chi}^{2}=85.74 \\
\mathrm{p}=.00\end{array}$ & -.99 & 1.29 & -.30 & 5.15 \\
\hline
\end{tabular}

Tabel 1.3.8 toont de $2^{\mathrm{e}}$-orde parameterschattingen van beroepsniveau, opleidingsniveau en SES-wijk naar categorieën van burgerlijke staat. De significante verschillen in beroepsniveau, opleidingsniveau en type SES-wijk met betrekking tot burgerlijke staat vertonen eenzelfde patroonmatigheid. Arbeiders enLO-ers zijn minder vaak gehuwd terwijl mannen met een hoger beroep en HBO-ers of academici juist vaker wel gehuwd zijn. Bewoners van de lage en de laag-midden SES-wijk zijn minder vaak gehuwd terwijl de bewoners van de hoog-midden en hoge SES-wijk juist vaker gehuwd zijn. 
Tabel 1.3.8 De resultaten van log-frequentie-analyse van burgerlijke staat naar categorieźn van beroep, opleiding en SES-wijk

\begin{tabular}{|c|c|c|c|}
\hline & gehuwd & niet gehuwd & \\
\hline $\begin{array}{l}\text { arbeider } \\
\text { employee } \\
\text { hoger beroep }\end{array}$ & $\begin{array}{r}1313 \\
1136 \\
445\end{array}$ & $\begin{array}{r}250 \\
108 \\
27 \\
\end{array}$ & \\
\hline $\begin{array}{l}\text { arbeider } \\
\text { employee } \\
\text { boger beroep }\end{array}$ & $\begin{array}{l}-.31^{*} \\
.05 \\
.26^{*}\end{array}$ & $\begin{array}{l}.31 * \\
-.05 \\
-.26^{*}\end{array}$ & $\begin{array}{r}.71 \\
.23 \\
-.94 \\
\end{array}$ \\
\hline $\begin{array}{l}\mathrm{chi}^{2}=58.86 \\
\mathrm{p}=.00\end{array}$ & 1.14 & -1.14 & 5.64 \\
\hline $\begin{array}{l}\text { LO } \\
\text { LBO } \\
\text { MO } \\
\text { HBO/universiteit }\end{array}$ & $\begin{array}{r}1297 \\
679 \\
601 \\
332 \\
\end{array}$ & $\begin{array}{r}246 \\
64 \\
55 \\
22 \\
\end{array}$ & \\
\hline $\begin{array}{l}\text { LO } \\
\text { MBO } \\
\text { MO } \\
\text { HBO/universiteit }\end{array}$ & $\begin{array}{l}-.31 * \\
.04 \\
.05 \\
.22^{*}\end{array}$ & $\begin{array}{l}.31^{*} \\
-.04 \\
-.05 \\
-.22^{*}\end{array}$ & $\begin{array}{r}1.00 \\
.01 \\
-.13 \\
-.88 \\
\end{array}$ \\
\hline $\begin{array}{l}\mathrm{chi}^{2}=51.78 \\
\mathrm{p}=.00\end{array}$ & 1.14 & -1.14 & 5.34 \\
\hline $\begin{array}{l}\text { lage SES } \\
\text { laag-midden } \\
\text { hoog-midden } \\
\text { hoge SES }\end{array}$ & $\begin{array}{l}576 \\
715 \\
875 \\
778 \\
\end{array}$ & $\begin{array}{r}145 \\
148 \\
54 \\
42 \\
\end{array}$ & \\
\hline $\begin{array}{l}\text { lage SES } \\
\text { lag-midden } \\
\text { hoog-midden } \\
\text { hoge SES }\end{array}$ & $\begin{array}{r}-.39 * \\
-.29^{*} \\
.31^{*} \\
.37^{*} \\
\end{array}$ & $\begin{array}{l}.39 * \\
.29 * \\
-.31 * \\
-.37 * \\
\end{array}$ & $\begin{array}{r}.16 \\
.28 \\
-.13 \\
-.31 \\
\end{array}$ \\
\hline $\begin{array}{l}\mathrm{chi}^{2}=143.67 \\
\mathrm{p}=.00\end{array}$ & 1.08 & -1.08 & 5.51 \\
\hline
\end{tabular}

In tabel 1.3.9 staan de resultaten van eenwegvariantie-analyses voor de logaritmisch getransformeerde SES-index met roken en alcoholconsumptie. Tabel 1.3.10 toont de resultaten van t-testen voor diabetes mellitus en burgerlijke staat met de SESindex.

Tabel 1.3.9 laat zien dat er een significant verband bestaat tussen de SES-index enerzijds en roken en alcoholconsumptie anderzijds. Nooit-rokers en ex-rokers hebben gemiddeld de hoogste sociaal-economische status (respectievelijk 4.97 en 4.92). Matige rokers hebben gemiddeld een lagere sociaal-economische status (4.62). De groep van 
zware rokers tenslotte wordt door het laagste gemiddelde van sociaal-economische status gekenmerkt (4.01). De richting van het verband tussen alcoholconsumptie en SES-schaal is in zeker opzicht tegenovergesteld aan dat van roken. Bij alcoholconsumptie heeft de groep van nooit drinkers gemiddeld de laagste sociaal-economische status (3.83). Daarentegen hebben matige drinkers gemiddeld de hoogste sociaal-economische status (4.52). In vergelijking tot nooit drinkers en matige drinkers is bij de groep van zware drinkers respectievelijk een hoger en een lager gemiddelde van sociaal-economische status vastgesteld.

Tabel 1.3.9 Resultaten ran eenwegvariantie-analyses voor SES-index met roken en alcoholconsumptie

\begin{tabular}{|c|c|c|c|c|c|c|}
\hline & $\mathbf{N}$ & gem. & gem. SSB (df) & gem. SSW (df) & $\mathbf{F}$ & p \\
\hline $\begin{array}{l}\text { Roken: } \\
\text { nooil gerookt } \\
\text { ex-roker } \\
\text { matige roker } \\
\text { zware roker }\end{array}$ & $\begin{array}{r}224 \\
801 \\
519 \\
1607\end{array}$ & $\begin{array}{l}4.97 \\
4.92 \\
4.62 \\
4.01\end{array}$ & $\begin{array}{c}184.58 \\
\text { (3) }\end{array}$ & $\begin{array}{c}3.19 \\
(3147)\end{array}$ & 57.87 & .00 \\
\hline $\begin{array}{l}\text { Alcohol: } \\
\text { nooit drinker } \\
\text { matige drinker } \\
\text { zware drinker }\end{array}$ & $\begin{array}{r}265 \\
2391 \\
485\end{array}$ & $\begin{array}{l}3.83 \\
4.52 \\
4.22\end{array}$ & $\begin{array}{l}66.99 \\
(2)\end{array}$ & $\begin{array}{c}3.32 \\
(3138)\end{array}$ & 20.15 & .00 \\
\hline
\end{tabular}

Tabel 1.3.10 laat zien dat burgerlijke staat in tegenstelling tot diabetes mellitus significant gerelateerd is aan sociaal-economische status. De niet-gehuwden hebben gemiddeld een significant lagere sociaal-economische status dan de gehuwde mannen.

Tabel 1.3.10 Resultaten van t-testen voor diabetes mellitus en burgerlijke staat met SESi-index

\begin{tabular}{|l|l|r|r|r|r|r|}
\hline & & $\mathrm{N}$ & \multicolumn{1}{c|}{ gem. } & \multicolumn{1}{c|}{ SD } & \multicolumn{1}{c|}{1} & \multicolumn{1}{c|}{ P } \\
\hline \multirow{2}{*}{ SES } & geen diabetes & 3091 & 4.41 & 1.83 & & \\
& wel diabetes & 62 & 4.63 & 1.80 & -.97 & .33 \\
\hline \multirow{2}{*}{ SES } & niet gehuwd & 367 & 3.68 & 1.66 & & \\
& wel gehuwd & 2786 & 4.51 & 1.83 & 8.17 & .00 \\
\hline
\end{tabular}

De relaties tussen beroepsniveau, opleidingsniveau en SES-wijk enerzijds en de continue cardiovasculaire risicofactoren Queteletindex, systolische en diastolische bloeddruk, cholesterol en leeftijd anderzijds die met behulp van eenwegvariantie-analyses werden vastgesteld, worden in de tabellen $1.3 .11 \mathrm{t} / \mathrm{m} \mathrm{1.3.13} \mathrm{gepresenteerd.}$ 
Tabel 1.3.11 Resultaten van eenwegrariantie-analyses voor respectievelijk Queteletindex, bloeddruk, cholesterol en leeftijd met beroepsniveau

\begin{tabular}{|c|c|c|c|c|c|c|c|}
\hline & & $\mathbf{N}$ & gem. & gem.SSB (df) & $\begin{array}{r}\text { gem. } \\
\text { SSW (df) }\end{array}$ & $F$ & $\mathbf{P}$ \\
\hline $\begin{array}{l}Q \\
U \\
E \\
T\end{array}$ & $\begin{array}{l}\text { arbeider } \\
\text { employee } \\
\text { hoger beroep }\end{array}$ & $\begin{array}{r}1558 \\
1266 \\
472\end{array}$ & $\begin{array}{l}25.4 \\
25.6 \\
25.8\end{array}$ & $\begin{array}{c}443.7 \\
(2)\end{array}$ & $\begin{array}{l}90.2 \\
(3293)\end{array}$ & 4.92 & .01 \\
\hline $\begin{array}{l}\text { D } \\
\text { B } \\
P\end{array}$ & $\begin{array}{l}\text { arbeider } \\
\text { employee } \\
\text { hoger beroep }\end{array}$ & $\begin{array}{r}1565 \\
1271 \\
472\end{array}$ & $\begin{array}{l}79 \\
80 \\
81\end{array}$ & $\begin{array}{r}1034 \\
(2)\end{array}$ & $\begin{array}{c}147 \\
(3305)\end{array}$ & 7.04 & .00 \\
\hline $\begin{array}{l}\mathrm{S} \\
\mathrm{B} \\
\mathrm{P}\end{array}$ & $\begin{array}{l}\text { arbeider } \\
\text { employee } \\
\text { hoger beroep }\end{array}$ & $\begin{array}{r}1565 \\
1271 \\
472\end{array}$ & $\begin{array}{l}137 \\
138 \\
139\end{array}$ & $\begin{array}{r}376 \\
(2)\end{array}$ & $\begin{array}{c}406 \\
(3305)\end{array}$ & .93 & .40 \\
\hline $\begin{array}{l}\mathrm{C} \\
\mathrm{H} \\
\mathrm{O} \\
\mathrm{L}\end{array}$ & $\begin{array}{l}\text { arbeider } \\
\text { employee } \\
\text { hoger beroep }\end{array}$ & $\begin{array}{r}1565 \\
1269 \\
472\end{array}$ & $\begin{array}{l}201 \\
203 \\
203\end{array}$ & $\begin{array}{r}2552 \\
(2)\end{array}$ & $\begin{array}{c}1157 \\
(3303)\end{array}$ & 2.21 & .11 \\
\hline $\begin{array}{l}\text { A } \\
\text { G } \\
E\end{array}$ & $\begin{array}{l}\text { arbeider } \\
\text { employee } \\
\text { hoger beroep }\end{array}$ & $\begin{array}{r}1565 \\
1271 \\
472\end{array}$ & $\begin{array}{l}52.7 \\
52.4 \\
52.2\end{array}$ & $\begin{array}{l}55.6 \\
(2)\end{array}$ & $\begin{array}{c}18.4 \\
(3305)\end{array}$ & 3.02 & .05 \\
\hline
\end{tabular}

Tabel 1.3.11 laat zien dat bij tweezijdige toetsing en hantering van een significantieniveau van .05 alleen Queteletindex, diastolische bloeddruk en leeftijd significant samenhangen met beroepsniveau. Hoe hoger het beroepsniveau des te hoger zijn de overeenkomstige gemiddelden van Queteletindex en diastolische bloeddruk. Verder hebben arbeiders gemiddeld een hogere leeftijd dan employees en mannen met een hoger beroep (respectievelijk 52.7, 52.4 en 52.2 jaar). Hierbij dient wel te worden opgemerkt dat de verschillen in gemiddelden in absolute termen niet groot zijn. Uit tabel 1.3.12 blijkt dat alleen diastolische bloeddruk en leeftijd significant gerelateerd zijn aan opleidingsniveau. LO-ers en LBO-ers hebben gemiddeld een lagere diastolische bloeddruk dan mannen die middelbaar onderwijs genoten hebben en HBO-ers of academici (respectievelijk 79 en $81 \mathrm{mmHg}$ ). Verder hebben LO-ers gemiddeld een hogere leeftijd dan mannen behorende tot de overige opleidingscategorieën (respectievelijk 53 en 52 jaar). Ook hier geldt dat de verschillen in gemiddelden in absolute termen niet groot zijn. Tabel 1.3.13 toont dat respectievelijk Queteletindex en leeftijd significant samenhangen met het type SES-wijk. Bewoners van de laag-midden en hoog-midden SES-wijk hebben gemiddeld de laagste Queteletindex (25.4). De bewoners van de lage SES-wijk worden door een hoger indexgemiddelde (25.5) gekenmerkt. De bewoners van de hoge SES-wijk tenslotte hebben het hoogste indexgemiddelde (25.8). Bewoners van de lage en de laag-midden SES-wijk hebben gemid- 
deld een hogere leeftijd ( 52.7 en 52.8 jaar) dan bewoners van de hoog-midden en hoge SES-wijk (52.0 en 52.2 jaar). Voor de hierboven beschreven verschillen in gemiddelden geldt eveneens dat ze in absolute termen niet groot zijn.

Tenslotte werden ter vaststelling van de relaties tussen Queteletindex, systolische en diastolische bloeddruk, cholesterol en leeftijd enerzijds en de logaritmisch getransformeerde SES-index anderzijds Pearson product-moment correlaties berekend. De correlatiecoëfficiënten alsmede de p-waarden van de overeenkomstige toetsingsgrootheden staan in tabel 1.3.14 weergegeven. De tabel laat zien dat een verhoging van zowel Queteletindex als cholesterolgehalte gepaard gaat met een significant hogere sociaal-economische status. Een hogere leeftijd gaat gepaard met een significant lagere sociaal-economische status. In absolute zin zijn deze correlaties laag.

Tabel 1.3.12 Resultaten van eenweg variantie-analyses voor respectievelijk Quetetindex, bloeddruk, cholesterol en leeftijd met opleidingsniveau

\begin{tabular}{|c|c|c|c|c|c|c|c|}
\hline & & $\mathbf{N}$ & gem. & gem. SSB (df) & gem. SSW (df) & F & p \\
\hline $\begin{array}{l}\text { Q } \\
\text { U } \\
\text { E } \\
T\end{array}$ & $\begin{array}{l}\text { LO } \\
\text { LBO } \\
\text { MO } \\
\text { HBO/uni }\end{array}$ & $\begin{array}{r}1536 \\
740 \\
656 \\
354 \\
\end{array}$ & $\begin{array}{l}25.4 \\
25.6 \\
25.7 \\
25.6\end{array}$ & $\begin{array}{c}203.7 \\
(3)\end{array}$ & $\begin{array}{c}90.9 \\
(3282)\end{array}$ & 2.24 & .08 \\
\hline $\begin{array}{l}\text { D } \\
\text { B } \\
\text { P }\end{array}$ & $\begin{array}{l}\text { LO } \\
\text { LBO } \\
\text { MO } \\
\text { HBO/uni }\end{array}$ & $\begin{array}{r}1545 \\
743 \\
656 \\
334 \\
\end{array}$ & $\begin{array}{l}79 \\
79 \\
81 \\
81\end{array}$ & $\begin{array}{r}1009 \\
(3)\end{array}$ & $\begin{array}{c}147 \\
(3294)\end{array}$ & 6.88 & .00 \\
\hline $\begin{array}{l}\text { S } \\
\text { B } \\
\text { P }\end{array}$ & $\begin{array}{l}\text { LO } \\
\text { LBO } \\
\text { MO } \\
\text { HBO/uni }\end{array}$ & $\begin{array}{r}1535 \\
743 \\
656 \\
354 \\
\end{array}$ & $\begin{array}{l}138 \\
138 \\
139 \\
138 \\
\end{array}$ & $\begin{array}{l}588 \\
(3)\end{array}$ & $\begin{array}{c}407 \\
(3294)\end{array}$ & 1.45 & .23 \\
\hline $\begin{array}{l}\mathrm{C} \\
\mathrm{H} \\
\mathrm{O} \\
\mathrm{L}\end{array}$ & $\begin{array}{l}\text { LO } \\
\text { LBO } \\
\text { MO } \\
\text { HBO/uni }\end{array}$ & $\begin{array}{r}1545 \\
742 \\
655 \\
354 \\
\end{array}$ & $\begin{array}{l}201 \\
200 \\
205 \\
202\end{array}$ & $\begin{array}{r}2585 \\
(3)\end{array}$ & $\begin{array}{c}1156 \\
(3292)\end{array}$ & 2.24 & .08 \\
\hline $\begin{array}{l}\text { A } \\
\text { G } \\
\text { E }\end{array}$ & $\begin{array}{l}\text { LO } \\
\text { LBO } \\
\text { MO } \\
\text { HBO/uni }\end{array}$ & $\begin{array}{r}1545 \\
743 \\
656 \\
354\end{array}$ & $\begin{array}{l}53.0 \\
52.1 \\
52.3 \\
51.8\end{array}$ & $\begin{array}{c}275.5 \\
(3)\end{array}$ & $\begin{array}{c}18.2 \\
(3294)\end{array}$ & 15.16 & .00 \\
\hline
\end{tabular}


Tabel 1.3.13 Resultaten van eenwegvariantie-analyses voor respectievelijk Queteletindex, bloeddruk, cholesterol en leeftijd met SES-wijk

\begin{tabular}{|c|c|c|c|c|c|c|c|}
\hline & & $\mathbf{N}$ & gem. & gem. SSB (df) & gem. SSW (df) & $\mathrm{F}$ & $\mathbf{p}$ \\
\hline $\begin{array}{l}Q \\
U \\
\text { E } \\
T\end{array}$ & $\begin{array}{l}\text { lage wijk } \\
\text { loag-midden } \\
\text { boog-midden } \\
\text { hoge wijk }\end{array}$ & $\begin{array}{l}737 \\
868 \\
925 \\
821 \\
\end{array}$ & $\begin{array}{l}25.5 \\
25.4 \\
25.4 \\
25.8 \\
\end{array}$ & $\begin{array}{c}420.3 \\
(3) \\
\end{array}$ & $\begin{array}{r}90.5 \\
(3347)\end{array}$ & 4.64 & .00 \\
\hline $\begin{array}{l}\mathrm{D} \\
\mathrm{B} \\
\mathrm{P}\end{array}$ & $\begin{array}{l}\text { lage wijk } \\
\text { laag-midden } \\
\text { hoog-midden } \\
\text { hoge wijk }\end{array}$ & $\begin{array}{l}741 \\
870 \\
931 \\
822\end{array}$ & $\begin{array}{l}80 \\
79 \\
80 \\
81\end{array}$ & $\begin{array}{c}364 \\
(3)\end{array}$ & $\begin{array}{c}148 \\
(3360)\end{array}$ & 2.46 & .06 \\
\hline $\begin{array}{l}\mathrm{S} \\
\mathrm{B} \\
\mathrm{P}\end{array}$ & $\begin{array}{l}\text { lage wijk } \\
\text { laag-midden } \\
\text { hoog-midden } \\
\text { hoge wijk }\end{array}$ & $\begin{array}{l}741 \\
870 \\
931 \\
822 \\
\end{array}$ & $\begin{array}{l}138 \\
138 \\
138 \\
138\end{array}$ & $\begin{array}{l}37 \\
(3)\end{array}$ & $\begin{array}{c}409 \\
(3360)\end{array}$ & .09 & .97 \\
\hline $\begin{array}{l}\mathrm{C} \\
\mathrm{H} \\
\mathrm{O} \\
\mathrm{L}\end{array}$ & $\begin{array}{l}\text { lage wijk } \\
\text { laag-midden } \\
\text { hoog-midden } \\
\text { hoge wijk }\end{array}$ & $\begin{array}{l}741 \\
868 \\
931 \\
822 \\
\end{array}$ & $\begin{array}{l}201 \\
200 \\
203 \\
202\end{array}$ & $\begin{array}{r}1765 \\
(3)\end{array}$ & $\begin{array}{c}1164 \\
(3358)\end{array}$ & 1.52 & .21 \\
\hline $\begin{array}{l}\text { A } \\
\text { G } \\
\text { E }\end{array}$ & $\begin{array}{l}\text { lage wijk } \\
\text { laag-midden } \\
\text { hoog-midden } \\
\text { hoge wijk }\end{array}$ & $\begin{array}{l}741 \\
870 \\
932 \\
822\end{array}$ & $\begin{array}{l}52.7 \\
52.8 \\
52.0 \\
52.2\end{array}$ & $\begin{array}{c}123.3 \\
(3)\end{array}$ & $\begin{array}{c}18.3 \\
(3361)\end{array}$ & 6.72 & .00 \\
\hline
\end{tabular}

Tabel 1.3.14 Pearson product-moment correlaties voor respectievelijk Queteletindex, bloeddruk, cholestorol en leeftijd met de logaritmisch getransformeerde SES-index

\begin{tabular}{|l|l|l|l|l|l|}
\hline & QUET & DBP & SBP & CHOL & AGE \\
\hline SES-index & .06 & .02 & .02 & .05 & -.06 \\
& $(3154)$ & $(3152)$ & $(3154)$ & $(3142)$ & $(3154)$ \\
& $\mathrm{p}=.00$ & $\mathrm{p}=.21$ & $\mathrm{p}=.23$ & $\mathrm{p}=.00$ & $\mathrm{p}=.00$ \\
\hline
\end{tabular}

\subsubsection{Samenvatting cross-sectionele resultaten}

Alle vier operationalisaties van sociaal-economische status bleken samen te hangen met gezondheidsopvattingen en de houding tegenover artsen. Met betrekking tot de schatting van de kans dat men binnen 5 tot 10 jaar een ernstige ziekte krijgt alsmede de mogelijkheden die men zelf heeft om ziekte te voorkomen, is het algemene beeld dat naarmate de sociaal-economische status lager is de verwachtingen pessimistischer zijn.

Daarentegen blijkt de waardering van gezondheid het hoogst in de lagere SESstrata te zijn. Mannen met een hogere sociaal-economische status achten vaker andere 
dingen even belangrijk als gezondheid. $\mathrm{Zij}$ die zeggen liever prettig en korter te leven zijn vrijwel gelijk over de strata verdeeld.

Sociaal-economische status bleek verder een negatieve samenhang te hebben met de mate waarin men wil weten wat een medische behandeling inhoudt.

Met betrekking tot de cardiovasculaire risicofactoren werd geen associaties tussen de vier SES-strata en diabetes gevonden. In de lagere strata wordt meer gerookt dan in de hogere strata. Reeds in 1972 zijn personen uit het hoogste stratum al vaker gestopt met roken. "Nooit-drinkers" worden vooral bij arbeiders aangetroffen. In de hogere beroepen wordt vaker matig gedronken. De categorie "zwaar drinken" heeft weinig of geen consistente samenhang met sociaal-economische status.

Sociaal-economische status bleek verder weinig samenhang te vertonen met (systolische en diastolische) bloeddruk, cholesterol, Queteletindex en leeftijd. Sommige associaties waren weliswaar statistisch significant maar de absolute verschillen waren gering. Voorzover er van een verband sprake is kan men zeggen dat hogere waarden van diastolische bloeddruk, Queteletindex en cholesterol iets vaker in de hogere strata aangetroffen werden. Een ietwat hogere leeftijd werd tenslotte in de laagste strata waargenomen.

\subsubsection{De relatie tussen SES en gezondheid, uitgedrukt in termen van hart- en vaatziekten}

In deze paragraaf wordt ingegaan op de relaties tussen sociaal-economische status en gezondheid, uitgedrukt in termen van hart- en vaatziekten. Hart- en vaatziekten werden onderscheiden in "soft events" (angina pectoris/bypass en mogelijke nonfatale infarcten), "hard events" (fatale infarcten en waarschijnlijk of zekere non-fatale infarcten) en alle coronaire aandoeningen (soft events en hard events). Ter verkrijging van inzicht in de (univariate) relaties tussen de vier SES-variabelen en het optreden van deze drie cardiale eindpunten werden met behulp van logistische regressie van alle vier vormen van sociaal-economische status de ruwe relatieve risico's berekend. Deze worden in tabel 1.3.15 gepresenteerd. De tabel laat zien dat de dummy-contrasten van beroepsniveau, opleidingsniveau, SES-wijk alsmede de continue (niet getransformeerde) SES-index op univariaat niveau niet significant gerelateerd zijn aan de cardiale eindpunten. Nadere bestudering van tabel 1.3.15 openbaart een zekere patroonmatigheid in de (niet-significante) relatieve risico's. Arbeiders en employees blijken een grotere kans op hart- en vaatziekten te hebben dan mannen met een hoger beroep. Ook mannen die respectievelijk lager onderwijs, lager beroepsonderwijs en middelbaar onderwijs hebben genoten, hebben een groter risico op hart- en vaatziekten dan HBOers of academici. De relatieve risico's van de SES-index geven aan dat stijging in sociaal-economische status gepaard gaat met een kleinere kans op hart-en vaatziekten ofwel hoe lager de sociaal-economische status des te groter de kans op hart-en vaataandoeningen. Voor de dummy-contrasten van de ecologische factor SES-wijk is dit 
patroon slechts gedeeltelijk waar te nemen. In vergelijking tot de bewoners van de hoge SES-wijk blijken alleen de bewoners van de lage SES-wijk een groter risico op "soft events" te hebben. Ten aanzien van het eindpunt alle coronaire aandoeningen hebben alleen de bewoners van de lage alsmede de laag-midden SES-wijk een verhoogd risico. Daarentegen blijken de bewoners van de lage, de laag-midden en de hoog-midden SES-wijk allen een groter risico op "hard events" dan de bewoners van de hoge SES-wijk te hebben.

Tabel 1.3.15 De met logistische regressieanalyse verkregen benaderingen voor de ruwe relatieve risico's van beroepsniveau (referentiecategorie = hoger beroep), opleidingsniveau (referentiecategorie $=$ HBO/universiteit), SES-wijk (referentiecategorie = hoge SES-wijk) en (de niet getransformeerde) SES-index ten aanzien van hart- en vastriekten

\begin{tabular}{|c|c|c|c|c|c|c|}
\hline \multirow{2}{*}{$\begin{array}{l}\text { Beroep } \\
\text { arbeider } \\
\text { employee }\end{array}$} & \multicolumn{2}{|c|}{$\begin{array}{l}\text { soft events } \\
\text { RR 95\% BI }\end{array}$} & \multicolumn{2}{|c|}{$\begin{array}{l}\text { hard events } \\
\text { RR } 95 \% \mathrm{BI}\end{array}$} & \multicolumn{2}{|c|}{$\begin{array}{l}\text { alle coronaire aandoenin- } \\
\text { gen } \\
\text { RR } 95 \% \text { BI }\end{array}$} \\
\hline & $\begin{array}{l}1.60 \\
1.33\end{array}$ & $\begin{array}{l}.73-3.50 \\
.60-2.90\end{array}$ & $\begin{array}{l}1.30 \\
1.32\end{array}$ & $\begin{array}{l}.77-2.18 \\
.79-2.19\end{array}$ & $\begin{array}{l}1.38 \\
1.32\end{array}$ & $\begin{array}{l}.89-2.15 \\
.86-2.03\end{array}$ \\
\hline $\begin{array}{l}\text { Opleiding } \\
\text { LO } \\
\text { L.BO } \\
\text { MO }\end{array}$ & $\begin{array}{l}1.77 \\
2.52 \\
2.47\end{array}$ & $\begin{array}{l}.66-5.54 \\
.85-7.47 \\
.87-6.99\end{array}$ & $\begin{array}{l}1.29 \\
1.06 \\
1.34\end{array}$ & $\begin{array}{l}.70-2.38 \\
.57-1.96 \\
.77-2.33\end{array}$ & $\begin{array}{l}1.39 \\
1.35 \\
1.56\end{array}$ & $\begin{array}{l}.90-2.39 \\
.79-2.31 \\
.95-2.56\end{array}$ \\
\hline $\begin{array}{l}\text { SES-wijk } \\
\text { laag } \\
\text { laag-midden } \\
\text { hoog-midden }\end{array}$ & $\begin{array}{l}1.58 \\
.92 \\
.70\end{array}$ & $\begin{array}{l}.86-2.90 \\
.45-1.86 \\
.31-1.59\end{array}$ & $\begin{array}{l}1.08 \\
1.10 \\
1.10\end{array}$ & $\begin{array}{l}.70-1.66 \\
.70-1.71 \\
.68-1.76\end{array}$ & $\begin{array}{r}1.23 \\
1.04 \\
.98\end{array}$ & $\begin{array}{l}.86-1.76 \\
.71-1.53 \\
.64-1.48\end{array}$ \\
\hline SES-index $*$ & .84 & $.65-1.10$ & .91 & $.76-1.07$ & .89 & $.77-1.03$ \\
\hline
\end{tabular}

* De ruwe relatieve risico's voor de SES-index werden zodanig berekend dat ze de toe- of afname van het risico uitdrukken voor toename van 10 schasipunten.

Ter vaststelling van de voor Queteletindex, diastolische bloeddruk, cholesterol, leeftijd, roken, alcoholgebruik, diabetes mellitus en burgerlijke staat gecorrigeerde effecten van de vier SES-variabelen op "soft events", "hard events" en alle coronaire aandoeningen werden multivariate logistische regressies uitgevoerd. De resultaten van deze analyses staan in tabel 1.3.16.

Tabel 1.3.16 laat zien dat de vier SES-variabelen na correctie voor relevante cardiovasculaire risico-indicatoren niet significant gerelateerd zijn aan respectievelijk "soft events", "hard events" en alle coronaire aandoeningen. Nadere inspectie van de in tabel 1.3.16 gepresenteerde gecorrigeerde relatieve risico's maakt duidelijk dat de voor relevante cardiovasculaire risico-indicatoren gecorrigeerde effecten van sociaaleconomische status op enkele fluctuaties na nauwelijks verschillen met de univariate 
bevindingen. Dit betekent dat de genoemde cardiovasculaire risico-indicatoren de (nietsignificante) univariate associaties tussen SES en hart- en vaatziekten noch onderdrukken noch door confounding wegverklaren. Sociaal-economische status blijkt de gezondheid, uitgedrukt in termen van hart- en vaatziekten niet te beïnvloeden.

Tabel 1.3.16 De met multivariate logistische regressieanalyse verkregen benaderingen voor de gecorrigeerde relatieve risico's van beroepsniveau (r.c. = hoger beroep), opleidingsniveau (r.c. = HBO/universiteit), SES-wijk (r.c. = hoge SES-wijk) en (de niet getransformeerde) SES-wijk ten aanzien van hart- en vaatziekten

\begin{tabular}{|c|c|c|c|c|c|c|}
\hline \multirow{2}{*}{$\begin{array}{l}\text { Beroep: } \\
\text { arbeider } \\
\text { employee }\end{array}$} & \multicolumn{2}{|c|}{$\begin{array}{l}\text { soft events } \\
\text { ARR 95\% BI }\end{array}$} & \multicolumn{2}{|c|}{$\begin{array}{l}\text { hard events } \\
\text { ARR } 95 \% \mathrm{Bl}\end{array}$} & \multicolumn{2}{|c|}{$\begin{array}{l}\text { alle coronaire andoe- } \\
\text { ningen } \\
\text { ARR } 95 \% \text { BI }\end{array}$} \\
\hline & $\begin{array}{l}1.37 \\
1.20\end{array}$ & $\begin{array}{l}.61-3.09 \\
.52-2.73\end{array}$ & $\begin{array}{l}1.06 \\
1.04\end{array}$ & $\begin{array}{l}.62-1.78 \\
.61-1.77\end{array}$ & $\begin{array}{l}1.16 \\
1.09\end{array}$ & $\begin{array}{l}.73-1.82 \\
.69-1.73\end{array}$ \\
\hline $\begin{array}{l}\text { Opleiding: } \\
\text { LO } \\
\text { LBO } \\
\text { MO }\end{array}$ & $\begin{array}{l}1.72 \\
2.20 \\
2.20\end{array}$ & $\begin{array}{l}.54-5.42 \\
.72-6.71 \\
.75-6.44\end{array}$ & $\begin{array}{l}1.06 \\
.89 \\
1.05\end{array}$ & $\begin{array}{l}.56-1.99 \\
.47-2.12 \\
.58-2.90\end{array}$ & $\begin{array}{l}1.21 \\
1.16 \\
1.29\end{array}$ & $\begin{array}{l}.67-2.11 \\
.66-2.02 \\
.77-2.18\end{array}$ \\
\hline $\begin{array}{l}\text { SES-wijk: } \\
\text { leag } \\
\text { laag-midden } \\
\text { boog-midden }\end{array}$ & $\begin{array}{r}1.40 \\
.60 \\
.74 \\
\end{array}$ & $\begin{array}{l}.74-2.64 \\
.27-1.34 \\
.31-3.17 \\
\end{array}$ & $\begin{array}{l}.94 \\
.91 \\
.95\end{array}$ & $\begin{array}{l}.59-1.50 \\
.56-1.48 \\
.56-1.59\end{array}$ & $\begin{array}{l}1.08 \\
.83 \\
.90\end{array}$ & $\begin{array}{l}.73-1.58 \\
.54-1.26 \\
.57-1.41\end{array}$ \\
\hline SES-index * & .79 & $.55-1.13$ & .97 & $.81-1.17$ & .93 & $.79-1.10$ \\
\hline
\end{tabular}

idem tabel 1.3.15

\subsubsection{De relatie tussen SES en gezondheid, uitgedrukt in cardiale sterfte,} kankersterfte en totale sterfte

Ter verkrijging van inzicht in de (univariate) relaties tussen SES en gezondheid in termen van cardiale sterfte, kankersterfte en totale sterfte zijn met Cox regressie-analyse allereerst de ruwe relatieve risico's berekend. De resultaten van deze analyses staan in tabel 1.3.17.

De tabel laat zien dat op univariaat niveau geen van de vier SES-variabelen statistisch significant gerelateerd is aan cardiale sterfte. Toch valt er met vitzondering van de categorieën LBO en MO van opleidingsniveau een zekere patroon in deze nonsignificante relatieve risico's waar te nemen. In de lagere SES-strata van beroepsniveau en SES-wijk alsmede het laagste stratum van opleidingsniveau zijn de cardiale sterfterisico's groter dan in de overeenkomstige hoge referentiestrata. Het geschatte ruwe rela- 
tieve risico voor de SES-index bevestigt dit patroon: een verlaging van sociaal-economische status gaat immers gepaard met een verhoogde cardiale sterftekans.

Tabel 1.3.17 De met Cox regressie-analyse verkregen benaderingen voor de ruwe relatieve risico's van beroepsniveau (r.c. $=$ hoger beroep), opleidingsniveau (r.c. $=$ HBO/universiteit), SESwijk (r.c. = hoge SES-wijk) en (de niet getransformeerde) SES-index ten aanzien van cardiale sterfte, kankersterfte en totale sterfte

\begin{tabular}{|c|c|c|c|c|}
\hline & $\begin{array}{l}\text { cardiale sterfte } \\
\text { RR } 95 \% \text { B.I. }\end{array}$ & $\begin{array}{l}\text { kankersterfte } \\
\text { RR 95\% B.I. }\end{array}$ & \multicolumn{2}{|c|}{$\begin{array}{l}\text { totale sterfte } \\
\text { RR } 95 \% \text { B.I. }\end{array}$} \\
\hline $\begin{array}{l}\text { arbeider } \\
\text { employee }\end{array}$ & $\begin{array}{ll}1.51 & .66-3.43 \\
1.76 & .78-4.00 \\
\end{array}$ & $\begin{array}{rr}2.36 & 1.17-4.73 \\
1.52 & .73-3.16 \\
\end{array}$ & $\begin{array}{l}2.14 \\
1.89\end{array}$ & $\begin{array}{l}1.43-3.20 \\
1.25-2.85\end{array}$ \\
\hline $\begin{array}{l}\text { Opleiding: } \\
\text { LO } \\
\text { LBO } \\
\text { MO }\end{array}$ & $\begin{array}{rr}1.13 & .52-2.44 \\
.92 & .39-2.20 \\
.95 & .44-2.29\end{array}$ & $\begin{array}{cc}1.92 & .92-4.00 \\
1.65 & .75-3.64 \\
.89 & .37-2.14\end{array}$ & $\begin{array}{l}1.74 \\
1.47 \\
1.26\end{array}$ & $\begin{array}{r}1.15-2.64 \\
.94-2.32 \\
.79-2.01\end{array}$ \\
\hline $\begin{array}{l}\text { SES-wijk: } \\
\text { laag } \\
\text { laag-midden } \\
\text { hoog-midden }\end{array}$ & $\begin{array}{ll}1.69 & .77-3.71 \\
1.98 & .95-4.11 \\
1.86 & .91-3.81\end{array}$ & $\begin{array}{cc}2.75 & 1.47-5.14 \\
3.08 & 1.68-5.62 \\
1.50 & .77-2.91\end{array}$ & $\begin{array}{l}1.99 \\
2.12 \\
1.54\end{array}$ & $\begin{array}{l}1.42-2.79 \\
1.53-2.94 \\
1.10-2.16\end{array}$ \\
\hline SES-index * & $.87 \quad .67-1.13$ & $.54-.89$ & .79 & $.69-.90$ \\
\hline
\end{tabular}

De relatieve risico's voor de SES-index werden zodanig berekend dat ze de toe- of afname van het risico uitdrukken voor toename van 10 schaalpunten.

Beroepsniveau, SES-wijk en SES-index blijken op univariaat niveau een significante invloed op kankersterfte uit te oefenen. De significante invloed van beroepsniveau wordt door het dummycontrast van arbeiders versus hoger opgeleiden gegenereerd. Arbeiders blijken een 2.36 keer zo grote kans op kankersterfte te hebben als mannen met een hogere opleiding. Het significante effect van de ecologische factor SES-wijk wordt door de significante contrasten tussen de strata lage en laag-midden SES-wijk enerzijds en de hoge SES-wijk anderzijds gegenereerd (de ruwe relatieve risico's zijn respectievelijk 2.75 en 3.08). Verder blijkt een stijging van 10 schaalpunten in de SES-index gepaard te gaan met een significante afname in het risico op kankersterfte, ofwel mannen die 10 schaalpunten lager scoren hebben een 1.45 maal zo grote kans op sterfte ten gevolge van kanker ( $1 / .69)$.

Tenslotte blijkt uit de univariate analyses dat alle vier SES-variabelen statistisch significant aan totale sterfte zijn gerelateerd. Arbeiders en employees hebben respectievelijk een 2.14 en 1.89 maal zo groot sterfterisico als mannen met een hoger beroep. Van opleidingsniveau blijkt alleen het contrast tussen lager opgeleiden en hboers of academici statistisch significant te zijn $(R R=1.74)$. Het significante effect van 
de omgevingsfactor SES-wijk wordt door de significante contrasten tussen de lage en de laag-midden SES-wijk èn de hoge SES-wijk gegenereerd (de ruwe relatieve risico's zijn respectievelijk 1.99 en 2.12). Tenslotte blijken mannen die 10 schaalpunten lager op de SES-index scoren een 1.26 maal zo groot sterfterisico te hebben.

Ter vaststelling van de voor roken, alcoholconsumptie, leeftijd en burgerlijke staat gecorrigeerde effecten van de 4 SES-variabelen op kankersterfte en totale sterfte werden multivariate Cox regressie-analyses uitgevoerd. Ook voor de analyses op cardiale sterfte waar naast de hierboven genoemde risico-indicatoren ook voor diastolische bloeddruk, cholesterol, Queteletindex en diabetes mellitus werd gecorrigeerd, zijn multivariate Cox regressie-analyses toegepast. Hieraan voorafgaand werd met behulp van tijdsafhankelijke covariaten voor mogelijke schendingen van de proportional hazard assumptie gecontrôleerd (zie appendix 5). De assumptie bleek niet te worden geschonden zodat Cox regressie-analyses zonder problemen uitgevoerd kunnen worden. De benaderingen van de voor relevante risico-indicatoren gecorrigeerde relatieve risico's worden in tabel 1.3 .18 weergegeven.

De tabel laat zien dat geen van de vier SES-variabelen in de multivariate situatie statistisch significant aan cardiale sterfte gerelateerd is. Ten aanzien van cardiale sterfte is er praktisch geen verschil tussen de ruwe en de gecorrigeerde relatieve risico's. Dit betekent dat de univariate associaties door de gespecificeerde risico-indicatoren noch onderdrukt noch door confounding wegverklaard worden.

$\mathrm{Na}$ correctie voor relevante risico-indicatoren blijken alleen de dummycontrasten van SES-wijk statistisch significant aan kankersterfte gerelateerd te zijn. De statistisch significante univariate effecten van beroepsniveau en SES-index verdwijnen als er gecorrigeerd wordt voor relevante risico-indicatoren. De risico-indicatoren die voor deze confounding verantwoordelijk zijn, zijn in volgorde van belangrijkheid respectievelijk roken, burgerlijke staat en leeftijd. Arbeiders roken meer, zijn minder vaak gehuwd en hebben een hogere leeftijd dan mannen van de overige beroepsstrata. Tevens gaat veel roken, het niet gehuwd zijn en een hogere leeftijd gepaard met een verhoogd risico op kankersterfte. Met andere woorden beroepsniveau is niet direct gerelateerd aan kankersterfte. De significante univariate associatie tussen beroepsniveau en kankersterfte wordt wegverklaard door roken, burgerlijke staat en leeftijd.

Ten aanzien van kankersterfte bleken de voor risico-indicatoren gecorrigeerde dummycontrasten tussen de lage en de laag-midden SES-wijk enerzijds en de hoge SES-wijk anderzijds qua effectsterkte kleiner te zijn dan de univariat resultaten (univariaat: 2.75 en 3.08; multivariaat: 2.22 en 2.40 ). Alhoewel kleiner bieven deze effecten wel statistisch significant. De reden voor deze verlaging in effectsterkte moet in de confounding van met name roken en leeftijd worden gezocht. Het met een indexverlaging van 10 schaalpunten gepaard gaande risico op kankersterfte bleek na correctie voor risico-indicatoren eveneens kleiner dan in de univariate situatie (univariaat: 1/.69 $=1.45$; multivariaat: $1 / .78=1.28$ ). Tevens was het gecorrigeerde risico in tegenstelling tot het ruwe risico niet meer statistisch significant (tweezijdige toetsing en een 
significantie niveau van .05). Het in de multivariate situatie geconstateerde lagere en niet significante risico op kankersterfte komt voort uit de confounding van roken en leeftijd.

Tabel 1.3.18 De met Cox regressie-analyse verkregen benaderingen voor de voor relevante risico-indicatoren gecorrigeerde relatieve risico's van beroepsniveau (r.c. = hoger beroep), opleidingsniveau (r.c. = HBO/universiteit), SES-wijk (r.c. $=$ hoge SES-wijk) en (de niet getransformeerde) SES-index ten aanzien van cardiale sterfte, kankersterfte en totale sterfte

\begin{tabular}{|c|c|c|c|c|c|c|}
\hline \multirow{2}{*}{$\begin{array}{l}\text { Beroep: } \\
\text { arbeider } \\
\text { employee }\end{array}$} & \multicolumn{2}{|c|}{$\begin{array}{l}\text { cardiale stefte } \\
\text { ARR } 95 \% \text { B.I. }\end{array}$} & \multicolumn{2}{|c|}{$\begin{array}{l}\text { kankersterfte } \\
\text { ARR } 95 \% \text { B.I. }\end{array}$} & \multicolumn{2}{|c|}{$\begin{array}{l}\text { totale sterfte } \\
\text { ARR } 95 \% \text { B.I. }\end{array}$} \\
\hline & $\begin{array}{l}1.18 \\
1.53\end{array}$ & $\begin{array}{l}.51-2.77 \\
.66-3.52\end{array}$ & $\begin{array}{l}1.70 \\
1.27\end{array}$ & $\begin{array}{l}.84-3.47 \\
.61-2.66\end{array}$ & $\begin{array}{l}1.67 \\
1.68\end{array}$ & $\begin{array}{l}1.11-2.53 \\
1.10-2.55\end{array}$ \\
\hline $\begin{array}{l}\text { Opleiding: } \\
\text { LO } \\
\text { LBO } \\
\text { MO }\end{array}$ & $\begin{array}{l}.94 \\
.79 \\
.69\end{array}$ & $\begin{array}{l}.42-2.09 \\
.32-1.93 \\
.27-1.76\end{array}$ & $\begin{array}{r}1.24 \\
1.35 \\
.76\end{array}$ & $\begin{array}{l}.59-2.64 \\
.61-2.99 \\
.31-1.83\end{array}$ & $\begin{array}{l}1.27 \\
1.28 \\
1.14\end{array}$ & $\begin{array}{l}.83-1.94 \\
.81-2.01 \\
.71-1.82\end{array}$ \\
\hline $\begin{array}{l}\text { SES-wijk: } \\
\text { laag } \\
\text { laag-midden } \\
\text { hoog-midden }\end{array}$ & $\begin{array}{l}1.6 \\
1.73 \\
1.87\end{array}$ & $\begin{array}{l}.70-3.73 \\
.79-3.78 \\
.87-4.04\end{array}$ & $\begin{array}{l}2.22 \\
2.40 \\
1.45\end{array}$ & $\begin{array}{r}1.16-4.22 \\
1.30-4.45 \\
.74-2.84\end{array}$ & $\begin{array}{l}1.76 \\
1.74 \\
1.50\end{array}$ & $\begin{array}{l}1.18-2.38 \\
1.24-2.34 \\
1.06-2.12\end{array}$ \\
\hline SES-index:* & .89 & $.67-1.18$ & .78 & $.61-1.02$ & .87 & $.76-.98$ \\
\hline
\end{tabular}

* idem tabel 1.3.17.

Tenslotte blijken in de multivariate analyses beroepsniveau, SES-wijk en SESindex statistisch significant aan totale sterfte gerelateerd te zijn. Ook voor deze variabelen zijn de multivariate effectschattingen kleiner dan bij univariate analyse. De verantwoordelijke confounders zijn wederom roken, burgerlijke staat en leeftijd. Het eerder geconstateerde significante univariate contrast tussen de LO-groep en HBO-ers of academici ten aanzien van totale sterfte verdween bij multivariate analyse. Bovendien bleken de gecorrigeerde effecten van de dummy's van opleidingsniveau met betrekking tot totale sterfte kleiner te zijn dan de univariate effecten. Deze lagere, niet significante, gecorrigeerde sterfterisico's van opleidingsniveau worden door de confounding van roken, burgerlijke staat en leefuijd gegenereerd. In vergelijking tot mannen met hogere beroepen blijken arbeiders en employees respectievelijk een 1.67 en een 1.68 maal zo groot risico op totale sterfte te hebben. Bewoners van de lage, de laag-midden en hoog-midden SES-wijk hebben in vergelijking tot de bewoners van de hoge SES-wijk respectievelijk een 1.76 , een 1.74 en een 1.50 maal zo groot sterfterisico. Verder blijkt een verlaging in de SES-index met 10 schaalpunten te corresponderen met een toename $\operatorname{van} 15 \%$ in het sterfterisico $(1 / .87=1.15=15 \%)$. 
Bij de hierboven beschreven bevindingen van beroepsniveau en SES-wijk enerzijds en de SES-index anderzijds moeten een aantal kanttekeningen worden geplaatst. De constatering van zowel een significante invloed van beroepsniveau als SES-wijk op totale sterfte werpt de vraag op welk van beide kenmerken de belangrijkste voorspeller van deze gezondheidsoperationalisatie is. Is de uitoefening van een "lager" beroep schadelijker voor de gezondheid dan het wonen in een lagere SES-wijk? Of is nu net een combinatie van beide SES-kenmerken het meest gezondheidsschadend?

Deze laatste vraag heeft betrekking op de aanwezigheid van een statistische interactie tussen beroepsniveau en SES-wijk in relatie tot de totale sterfte. Met behulp van Cox regressie-analyse waarbij als extra variabelen de multiplicaties van de dummys van beroepsniveau en SES-wijk aan het model zijn toegevoegd, werd getoetst op de mogelijke aanwezigheid van een dergelijke interactie. Weglating van alle dummy multiplicaties uit dit verzadigde model leidde niet tot een significante verslechtering van de likelihood $\left(\mathrm{chi}^{2}=9.12 ; \mathrm{df}=6 ; \mathrm{p}=.16\right)$. Dit betekent dat er geen sprake is van een interactie tussen beroepsniveau en SES-wijk ten aanzien van totale sterfte.

Ter beantwoording van de vraag welke van de SES-indicatoren beroepsniveau en SES-wijk nu de belangrijkste determinant van totale sterfte is, werd er een stapsgewijze Cox regressie-analyse uitgevoerd. Bij fixering van leeftijd, roken, alcoholconsumptie en burgerlijke staat bleek alleen de variabele SES-wijk in het Cox regressiemodel te worden opgenomen. De variabele beroepsniveau werd niet meer in het model opgenomen omdat de toevoeging van deze SES-indicator geen significante verbetering van de likelihood zou opleveren $\left(\mathrm{chi}^{2}=1.58 ; \mathrm{df}=2 ; \mathrm{p}=.45\right.$ ). Dit betekent allereerst dat SES-wijk de belangrijkste voorspeller van totale sterfte is en verder dat SESwijk een dusdanige confounder van het beroepsniveau is dat deze het eerder vastgestelde significante afzonderlijke effect van beroepsniveau zodanig verkleint dat het in termen van statistische termen geen rol meer speelt. Dit betekent echter niet dat de in tabel 1.3.18 gepresenteerde gecorrigeerde sterfterisico's van SES-wijk nu de meest valide effectschattingen zijn. Immers als SES-wijk een confounder van beroepsniveau is dan geldt omgekeerd ook dat in hun onderlinge relatie tot totale sterfte het beroepsniveau een (weliswaar niet significante) confounder van de SES-wijk is. Valide effectschattingen van SES-wijk kunnen daarom alleen verkregen worden als ook voor de invloed van beroepsniveau wordt gecorrigeerd. Derhalve werd nogmaals een Cox analyse uitgevoerd waarbij het beroepsniveau naast SES-wijk, leeftijd, roken, alcoholconsumptie en burgerlijke staat gedwongen in het model werd opgenomen. In tabel 1.3.19 zijn de op grond van deze analyse verkregen gecorrigeerde sterfterisico's van zowel beroepsniveau als SES-wijk weergegeven.

De tabel laat zien dat de variabele SES-wijk de belangrijkste predictor van totale sterfte is. Echter de effecten van de dummycontrasten van SES-wijk zijn kleiner (respectievelijk $1.54,1.64$ en 1.38) dan die voor de situatie waarin het beroepsniveau niet in het multivariate model werd opgenomen (aRR's waren respectievelijk 1.76, 1.74 en 1.50). Verder blijkt het in de afzonderlijke analyse geconstateerde significante 
contrast tussen de hoog-midden en de hoge SES-wijk na opname van beroepsniveau niet meer significant te zijn, waardoor ook de dichotomie tussen de hoge SES-wijk en de andere drie wijken, die suggereerde dat er vooral sprake is van een geprivilegieerde positie van de hoogste wijk, afgevlakt wordt. De verklaring voor deze bevindingen is evident: het beroepsniveau is een confounder van de SES-wijk. Mannen uit de lage SES-wijken hebben in het algemeen vaker een lager beroep. De uitoefening van een lager beroep gaat tevens met een grotere sterftekans gepaard. De significante associatie ussen SES-wijk en totale sterfte zoals die eerder in de afzonderlijke multivariate analyse werd vastgesteld, moet derhalve voor een deel aan het beroepsniveau worden toegeschreven.

Tabel 1.3.19 Gecorrigeerde sterfterisico's van beroep (r.c. = hoger beroep) en SES-wijk (r.c. = hoge SES-wijk) wanneer beide variabelen in het Cox model zijn opgenomen

\begin{tabular}{|l|l|l|}
\hline & ARR & $95 \%$ B.I. \\
\hline Beroep: & & \\
arbeider & 1.20 & $.73-1.95$ \\
employee & 1.33 & $.83-2.12$ \\
\hline SES-wijk: & & \\
lage SES-wijk & 1.54 & $1.02-2.32$ \\
laog-midden & 1.64 & $1.10-2.42$ \\
hoog-midden & 1.38 & $.94-2.06$ \\
\hline
\end{tabular}

Zoals eerder opgemerkt werd liet de Cox regressie-analyse een significante samenhang zien tussen totale sterfte en de overall SES-index. Om deze samenhang inzichtelijker te maken werd deze analyse herhaald, waarbij de respondenten ingedeeid werden in kwintielgroepen van de SES-index. Het resultaat hiervan is weergegeven in tabel 1.3.20.

Tabel 1.3.20 laat zien dat slechts ten dele de sterftekans groter wordt naarmate de waarden van de SES-index kleiner worden. Het verschil is statistisch echter niet meer significant terwijl ook geen duidelijk lineair verband meer aanwezig is. Dit maakt het niet ondenkbaar dat het eerder geconstateerde significante effect van de continue SES-index op de totale sterfte een artefact kan zijn.

Tabel 1.3.20 Gecorrigeerde sterfterisico's behorende tot kwintielgroepen van de SES index (referentiecategorie $=5^{e}$ SES-kwintiélgroep)

\begin{tabular}{|l|l|l|}
\hline & ARR & $95 \%$ B.I. \\
\hline SES-index: & & \\
$1^{c}$ kwintielgroep & 1.42 & $.97-2.09$ \\
$2^{c}$ kwintielgroep & 1.44 & $.96-2.16$ \\
$3^{c}$ kwintielgroep & 1.42 & $.98-2.07$ \\
$4^{c}$ kwintielgroep & 1.26 & $.86-1.86$ \\
\hline
\end{tabular}


Voorzichtigheidshalve wordt geconcludeerd dat de data weliswaar een indicatie maar geen overtuigend bewijs leveren dat de sterftekans toeneemt wanneer men lager scoort op een overall SES-index.

\subsubsection{Samenvatting follow-up resultaten}

Zowel de univariate als de multivariate analyses lieten zien dat geen van de vier operationalisaties van sociaal-economische status predictoren van gezondheid zijn als deze in termen van "soft-events", "hard-events", alle coronaire aandoeningen en cardiale sterfte worden uitgedrukt. Wel werden er significante verbanden geconstateerd als de gezondheid in termen van kankersterfte en totale sterfte wordt uitgedrukt.

Uit de univariate analyses bleek dat beroepsniveau, SES-wijk en SES-index significant samenhangen met kankersterfte. Na correctie voor risico-indicatoren blijkt alleen de SES-wijk en dan met name de contrasten tussen de lage en de laag-midden SES-wijk enerzijds en de hoge SES-wijk anderzijds significant aan kankersterfte gerelateerd te zijn. De, in de multivariate situatie, geconstateerde non-significante invloed van beroepsniveau en SES-index moet aan de confounding van leeftijd, burgerlijke staat en roken worden toegeschreven.

Totale sterfte bleek op univariaat niveau significant met alle vier SES-operationalisaties samen te hangen. Met uitzondering van opleidingsniveau bleven deze verbanden (weliswaar minder sterk) ook in de multivariate analyse bestaan. De non-significantie van opleidingsniveau en de in vergelijking tot de univariate situatie geringere effecten van beroepsniveau, SES-wijk en SES-index op totale sterfte moeten aan de confounding van met name leeftijd, burgerlijke staat en roken worden toegeschreven.

Wanneer beroepsniveau en de SES-wijk gelijktijdig in een multivariate analyse worden opgenomen blijkt dat de variabele beroepsniveau het predicerend vermogen met betrekking tot totale sterfte verliest. Het zijn dan de contrasten tussen de lage en de laagmidden SES-wijk enerzijds en de hoge SES-wijk anderzijds die statistisch significant met een verhoogde sterftekans samenhangen.

Aannemende dat de continue SES-index een lineaire samenhang met de overeenkomstige sterftekans vertoont, blijkt de continue SES-index in de multivariate situatie statistisch significant aan de totale sterfte gerelateerd te zijn. Controle op het daadwerkelijke voorkomen van een dergelijke "dose-respons"-relatie met behulp van een indeling in kwintielgroepen van de SES-index openbaarde dat er eigenlijk niet van een dergelijke "dose-respons"-relatie gesproken kan worden. Deze bevinding leidde tot de conclusie dat de data weliswaar een indicatie maar geen bewijs leveren dat de sterftekans samenhangt met de SES-index. 


\subsection{CONCLUSIE}

De resultaten van dit onderzoek bevestigen in een aantal opzichten het beeld dat er verschillen bestaan tussen min of meer onderscheiden SES-groepen ten aanzien van een aantal algemene opvattingen over ziekte en gezondheid, ten aanzien van riskante levensgewoonten, en ten aanzien van sterfte. Waar verschillen waargenomen werden, wezen ze over het algemeen in de richting van een voor de gezondheid nadelige situatie voor de lagere SES-groepen, al waren de verschillen, hoewel statistisch significant, absoluut soms betrekkelijk gering.

Opvattingen over ziekte en gezondheid blijken een duidelijke samenhang te vertonen met SES-niveau, ongeacht de wijze waarop dit niveau geoperationaliseerd werd. De resultaten geven aan dat de hoogste SES-groep het vaakst optimistisch is over de gezondheidsprognose, vaker vertrouwen had in de vermijdbaarheid van ziekte, en vaker behoefte had aan informatie bij eventuele medische behandeling. Naarmate het SES-niveau daalde, kwamen deze opvattingen relatief gezien minder vaak voor, en steeg de proportie van personen die tegenovergestelde opvattingen huldigden. Dit graduele verband werd in de meeste gevallen aangetroffen, al leek de hoogste SES-categorie er enigszins uit te springen, ongeacht of die categorie nu door beroepsklasse, schoolopleiding, of SES-wijk gedefinieerd werd. Het verschil van mening tussen deze groep (hoger beroep, HBO/universiteit, hoogste SES-wijk) en de daarop volgende groep (employee, MO, hoog-midden SES-wijk) was doorgaans aanzienlijk groter dan tussen laatstgenoemde groep en de daarop volgende groep(en). Tenslotte vond weliswaar de meerderheid van de hoogste SES-groep gezondheid het meest waardevolle in het leven, bij lagere SES-groepen heerste deze mening nog veel sterker.

Van de cardiovasculaire risicofactoren blijken er een aantal een duidelijke samenhang te vertonen met SES-niveau. Het percentage niet-rokers (nooit gerookt) en ex-rokers is duidelijk hoger in de hoogste SES-klasse, terwijl er zich in de laagste SES-groepen proportioneel veel meer zware rokers bevinden. Geheelonthouding was het meest prevalent in de laagste SES-klasse, en het minst prevalent in de hoogste SES-klasse. Voor het percentage matige drinkers gold het omgekeerde: dat kwam relatief vaker voor in de hoogste SES-groep en minder vaak in de laagste SES-groepen. Het percentage zware drinkers vertoonde geen duidelijke samenhang met beroepsklasse of opleidingsniveau, maar was wel hoger in de hoogste SES-wijk, en het laagst in de midden-hoge SES-wijk.

Hogere SES-groepen hadden doorgaans een hogere Queteletindex dan lagere SES-groepen, hoewel dat verband wat minder duidelijk was voor de verschillende niveau's van schoolopleiding. Ook diastolische bloeddruk steeg met SES-niveau al waren de verschillen in klinisch opzicht betrekkelijk gering. Systolische bloeddruk en cholesterolgehalte waren nagenoeg gelijk in iedere SES-groep, al was er dan een significant positieve relatie tussen de SES-index en cholesterol. 
Uit de analyses van de gezondheidsuitkomsten blijkt dat er in dit onderzoek geen verband bestond tussen SES en cardiovasculaire aandoeningen. Dit betreft zowel de morbiditeitsgegevens als de cardiale sterftegegevens. Totale sterfte en kankersterfte kwamen echter significant meer voor onder de laagste SES-groepen, wanneer de hoogste groep als norm werd genomen. De associatie tussen beroepsklasse en risico op kankersterfte viel echter weg na correctie voor rookgedrag en burgerlijke staat. De verschillen in kankersterfte en totale sterfte waren niet waameembaar wanneer verschillende schoolopleidingscategorieën met elkaar vergeleken werden. De meest kwetsbare categorieën wat betreft deze beide vormen van sterfte bleken de arbeiders en degenen uit lage en midden-lage SES-wijken te zijn. Employees vertoonden eveneens een duidelijk verhoogd sterfterisico in vergelijking met mensen met hogere beroepen. Van de omgevingsfactor SES-wijk en de beroepsklassefactor bleek de eerstgenoemde het belangrijkste voor totale sterfte.

Het onderzoek kende een aantal beperkingen die wellicht van invloed zijn geweest op de resultaten. De eerste beperking met een mogelijk storende invloed op een aantal verbanden is de non-participatie graad bij aanvang van de studie (49). Het percentage weigeringen om aan de studie deel te nemen varieerde per SES-wijk, en was hoger voor de laagste SES-wijk (18\%) dan voor de andere 3 SES-wijken (13, 8 en $12 \%$ voor resp. de hoge, midden-hoge en midden-lage SES-wijk) (3). Indien deze selectiebias van invloed is geweest op de resultaten dan heeft het wellicht eerder tot een onderschatting dan tot een overschatting van het verband tussen SES en risicofactoren of ziekte/sterfte-uitkomsten geleid. Het is mogelijk dat de niet-deelnemers over het algemeen iets ongezonder waren dan de deelnemers, aangezien gebrek aan goede gezondheid een reden kan zijn om van deelname af te zien. In dat geval zou deze groep hogere waarden op een of meer risicofactoren vertonen en daardoor een iets slechtere gezondheidsprognose hebben gehad. Vanwege het feit dat het percentage niet-deelnemers hoger was in de laagste SES-wijk kan dit dus tot een onderschatting hebben geleid van de in een aantal gevallen gevonden negatieve samenhang tussen SES en gezondheidsuitkomsten. Het was echter niet mogelijk om na te gaan of dit effect inderdaad heeft plaatsgevonden.

Een tweede beperking betreft de mogelijke invloed van de dataverzamelingsprocedure tijdens follow-up op de resultaten van het onderzoek. Zoals in paragraaf 2 beschreven, bestond de eerste stap van het verzamelen van de cardiovasculaire morbiditeitsgegevens uit een door de participant zelf in te vullen enquête. Zeven procent van de deelnemers hebben niet aan het morbiditeitsonderzoek meegewerkt, terwijl van $1 \%$ het adres niet te achterhalen viel. De mogelijkheid bestaat dat mensen met bijvoorbeeld een lage opleiding meer moeite hadden de enquête in te vullen, en dat er onder die groep tevens een verhoogde coronaire morbiditeit plaatsvond. Dit zou dan tot een onderschatting van het relatieve risico voor coronaire morbiditeit geleid hebben voor personen met een lage opleiding in vergelijking met degenen met een hogere opleiding. Niet-deelname aan het morbiditeitsonderzoek kwam inderdaad significant vaker voor 
bij lagere SES-groepen, met name onder arbeiders, onder degenen met alleen lagere schoolopleiding, of onder degenen uit de lage of laag-midden SES-wijk. Bij navraag bij een random sample van de niet-deelnemers bleek coronaire morbiditeit echter niet duidelijk vaker voorgekomen te zijn als bij de groep die wel aan het morbiditeitsonderzoek had deelgenomen. De kans is derhalve gering dat de groep van niet-deelnemers aan het follow-up onderzoek de resultaten sterk beïnvloed heeft.

Voorts kan er enige misclassificatie opgetreden zijn ten aanzien van de incidentie van angina, bypass, of non-fataal infarct. Dit zou het geval zijn als deelnemers de vraag of ze gedurende follow-up last hebben gehad van pijn op de borst of van ernstige hartklachten ten onrechte hebben ontkend (fout negatieven). Het zou de huidige resultaten met name beïnvloed hebben wanneer misclassificatie in ongelijke mate zou zijn opgetreden voor afzonderlijke SES-groepen, de zogenaamde differentiële misclassificatie. Dit zou namelijk tot zowel een overschatting als een onderschatting van het relatieve risico kunnen leiden. Indien de misclassificatie non-differentieel zou zijn, oftewel onafhankelijk van SES-klasse, dan wordt het relatieve risico in de richting van de nulhypothese afgezwakt (51). Misclassificatie of onderrapportage van fatale infarcten heeft waarschijnlijk niet plaatsgevonden aangezien de mortaliteitsgegevens van het Centraal Bureau voor Statistiek werden verkregen. Onderrapportage van angina, bypass of non-fataal infarct is daarentegen mogelijk. Dit komt omdat niet bekend is wie van degenen die aan een infarct overleden zijn in een eerder stadium tijdens follow-up aan angina of een non-fataal infarct geleden hebben, of reeds een bypass hadden ondergaan. Aangezien dat wel zeker bij een aantal het geval zal zijn geweest is de incidentie van non-fatale coronaire aandoeningen hoger dan hier gerapporteerd. Dit kan overigens alleen de resultaten van de "soft-events" beinnvloed hebben, aangezien bij de andere analyses over coronaire hartziekten de fatale infarcten telkens ingesloten waren. Of de misclassificatie bij de "soft-events" differentieel of non-differentieel over de SES-groepen was verdeeld, valt op grond van het huidige onderzoeksmateriaal niet te zeggen. De resultaten met betrekking tot het risico op deze groep van aandoeningen moet derhalve wel met de nodige voorzichtigheid betracht worden.

Als laatste beperking van dit onderzoek moet genoemd worden dat er geen herhalingsmetingen gedurende de follow-up periode hebben plaatsgevonden. Een van de gevolgen is hierboven reeds aangehaald, namelijk dat het onbekend is wie er voorafgaand aan een fataal infarct aan angina of een non-fataal infarct heeft geleden, of een bypass operatie heeft ondergaan. Voorts konden daardoor geen herhaalde metingen van factoren als roken gedaan worden. Verandering van rookgedrag gedurende de followup periode kan een "confounding" effect hebben gehad op bijvoorbeeld de relatie tussen SES en kankersterfte of totale sterfte. Het is mogelijk dat hogere SES-groepen in de follow-up tijd gemiddeld hun rookgedrag sterker hebben verminderd dan lagere SES-groepen, en als gevolg minder sterfte vertoond hebben. Het verband tussen SES en sterfte zou in zo'n geval aan verandering in rookgedrag moeten toegeschreven worden in plaats van aan de een of andere sociaal-economische karakteristiek zelf. 
Er dienen een drietal opmerkingen gemaakt te worden ten aanzien van de generaliseerbaarheid van de resultaten. Ten eerste mogen de resultaten niet zonder meer naar vrouwelijke populaties geëxtrapoleerd worden, aangezien de resultaten gebaseerd zijn op gegevens van een louter mannelijke steekproef. Ten tweede is de steekproef genomen in de stad Rotterdam. Derhalve moet enige voorzichtigheid in acht genomen worden bij het generaliseren van de huidige resultaten naar andere delen van het land, met name wellicht waar die gebieden verder van de randstad verwijderd zijn en/of een meer agrarisch karakter vertonen. Aan de andere kant woont het merendeel van de Nederlandse bevolking in stedelijke gebieden met wijken die veel overeenkomsten vertonen met de wijken die als basis voor de desbetreffende steekproef dienden.

Ten derde valt aan te voeren dat de resultaten gebaseerd zijn op gegevens uit de jaren zeventig, en dus niet geheel representatief zijn voor de huidige situatie, eind jaren tachtig. Zo ligt het percentage werklozen tegenwoordig een stuk hoger dan in de jaren zeventig. Voorts is er in Nederland tussen eind jaren zestig en midden jaren tachtig een duidelijke jaarlijkse daling opgetreden in zowel totale sterfte als in sterfte aan ischemische hartziekten. Het onderzoek van Mackenbach naar regionale sterfteverschillen tussen 1969 en 1984 liet zien dat de dalingen in sterfte sterker waren in gebieden met relatief gunstige of sinds de eind jaren zestig sterk verbeterde sociaal-economische omstandigheden (38). Nader onderzoek zal moeten uitwijzen of cardiale mortaliteit inmiddels wel gerelateerd is aan SES-klasse, en of de regionale verschillen zoals door Mackenbach gerapporteerd nu ook op individueel niveau terug te vinden zijn. Met andere woorden, het is mogelijk dat er sinds de jaren zeventig langzamerhand een oversterfte aan hartziekten is ontstaan in lagere SES-groepen.

Evenzo kan nagegaan worden of er meer uitgesproken verschillen zijn ontstaan in risicofactorwaarden tussen de verschillende SES-groepen. Recent onderzoek lijkt daar overigens geen aanwijzing toe te geven: er werd geen duidelijke relatie gevonden tussen opleidingsniveau en cholesterol of systolische bloeddruk (13). Aan de andere kant bleek in datzelfde onderzoek dat Queteletindex bij mannen licht daalde bij stijging van opleiding, terwijl dat in het onderhavige onderzoek precies andersom was. Duidelijke verschillen in rookgedrag tussen hogere en lagere SES-groepen werden reeds in dit onderzoek geconstateerd, en bestaan nu nog steeds $(12,13)$.

Hierboven werd reeds enigszins aangegeven dat de resultaten ten aanzien van de samenhang tussen sociaal-economische indicatoren en cardiovasculaire risicofactoren globaal in overeenstemming zijn met gegevens uit ander Nederlands onderzoek. Dat geldt met name voor rookgedrag, waarvan zowel in dit onderzoek als in twee andere Nederlandse onderzoeken $(12,13)$ is aangetoond dat het aanmerkelijk meer voorkomt bij lagere SES-groepen, en voor cholesterol en bloeddruk, waarvoor geen duidelijke relaties met SES zijn waargenomen (13). Ook de resultaten met betrekking tot alcoholgebruik komen overeen met eerder Nederlands onderzoek, waar eveneens een hoger percentage geheelonthouders onder lager opgeleiden werd gevonden, en een hogere gemiddelde alcoholconsumptie bij hoger opgeleiden (24). Alleen de uitkomsten 
voor wat betreft overgewicht waren verschillend met die van andere studies, die over het algemeen inverse relaties tussen SES en Queteletindex rapporteerden $(13,25)$. In dit onderzoek hadden mensen uit hogere SES-groepen juist een hogere gemiddelde Queteletindex.

Er is reeds kort ingegaan op het gebrek aan enige samenhang tussen SES-factoren en coronaire morbiditeit of cardiale mortaliteit. Er zijn op dit moment geen andere Nederlandse studies bekend waarmee deze resultaten vergeleken kunnen worden. De situatie in een aantal andere geïndustrialiseerde landen, zoals de Verenigde Staten en Groot Britanniē, geeft wel een duidelijke relatie aan tussen SES en met name sterfte aan coronaire hartziekten, waarbij het risico op deze vorm van sterfte het hoogst is onder de laagste SES-groepen $(27,30)$. Er is echter geopperd dat een negatieve relatie tussen sociaal-economische factoren en sterfterisico minder duidelijk aanwezig of zelfs afwezig zou zijn in populaties met de hoogste levensverwachting bij geboorte. Dit zou dan met name opgaan voor landen als Nederland en Zweden waar in sommige studies nauwelijks sterfteverschillen zijn gevonden voor onderscheiden SES-groepen $(45,36)$.

$\mathrm{Er}_{\mathrm{r}}$ is in ander onderzoek in Nederland daarentegen wel degelijk een relatie naar voren gekomen tussen opleidingsniveau en totale sterfte (13) en tussen SES-wijk als ecologische variabele en totale sterfte (46). De onderhavige resultaten sluiten daarbij slechts ten dele aan. Enerzijds was er een duidelijk verhoogd sterfterisico voor de beroepsklassen arbeiders en employees in vergelijking met hogere beroepen. Hetzelfde gold voor degenen die respectievelijk in een lage-, laag-midden-, en hoog-midden SESwijk woonden in vergelijking met degenen uit een hoge SES-wijk. Er is overigens nauwelijks sprake van enige lineariteit in deze samenhang; het sterfterisico neemt niet toe naarmate de sociaal-economische indicator afneemt. Deze gegevens suggereren eerder dat de hoogste SES-groep, vooral gedefinieerd als woonomgeving, geprivilegieerd is ten opzichte van de andere SES-groepen, en dat er tussen mensen uit de andere woonwijken nauwelijks verschillen in sterfterisico bestaan.

Anderzijds vertoonde opleidingsniveau géén samenhang met sterfterisico, en was het verband tussen de SES-index en sterfterisico bij nadere inspectie evenzeer verre van duidelijk. Categorisering van de SES-index liet zien dat het sterfterisico nauwelijks toenam bij het lager worden van de SES-index. Op grond van de gevonden resultaten kan niet geconcludeerd worden dat SES een duidelijke invloed heeft op sterfterisico, althans niet voor wat betreft de sociaal-economische indicator opleidingsniveau of de samengestelde index.

De resultaten voor risico op kankersterfte waren in hoge mate vergelijkbaar met die voor totaal sterfterisico, behalve dat de samenhangen tussen beroepsklasse, woonwijk of SES-index en kankersterfte vooral toe te schrijven waren aan verschillen in rookgedrag, leeftijd en/of burgerlijke staat tussen de SES-groepen. Er zijn geen andere gegevens bekend over sociaal-economische verschillen in kankersterfte in $\mathrm{Ne}$ derland. Het verdient derhalve aanbeveling om de samenhang tussen SES en risico op kankersterfte opnieuw te onderzoeken, waarbij wellicht onderscheid gemaakt dient te 
worden tussen de verschillende vormen van kanker. Wel lijkt de ongelijke verdeling van een aantal risicofactoren over de verschillende SES-groepen, met name rookgedrag en burgerlijke staat, aangrijpingspunten te bieden voor identificatie van personen met een verhoogd risico op deze vorm van sterfte.

In deze bijdrage is getracht sociaal-economische gezondheidsverschillen te beschrijven aan de hand van zowel enkelvoudige indicatoren van sociaal-economische status als aan de hand van een index. De constructie van deze index werd als een belangrijke aanvulling gezien op de bestudering van verschillen in gezondheid op basis van afzonderlijke indicatoren van sociaal-economische status. Ten eerste leverde de toepassing van deze index het voordeel op dat het multidimensionele concept sociaaleconomische stratificatie gereduceerd werd tot gemeenschappelijke componenten van sociale klasse en prestige. Ten tweede kon daardoor onderzocht worden of dergelijke gemeenschappelijke componenten andere inzichten zou opleveren met betrekking tot gezondheidsverschillen als het gebruik van een specifieke meting van sociaal-economische status zou doen.

Toepassing van de SES-index bij de analyse van gezondheidsopvattingen, cardiovasculaire risicofactoren en al dan niet fatale coronaire aandoeningen leverde geen noemenswaardige extra informatie op: de resultaten kwamen in grote mate overeen met die van de analyses voor de afzonderlijke SES-indicatoren. De analyses met betrekking op kankersterfte en totale sterfte leverde niet dezelfde resultaten op voor de verschillende sociaal-economische indicatoren. De vraag rijst waarom woonwijk wel het risico op kanker- en totale sterfte lijkt te beïnvloeden, terwijl beroepsklasse, opleiding of een overall SES-index dat niet lijken te doen. Men kan hierbij aan enkele mogelijke verklaringen denken. Het kan bijvoorbeeld zijn dat vervuiling en verontreiniging van de omgeving in de zogenaamde lagere SES-woonwijken in sterkere mate aanwezig zijn en aldus bijdragen tot verhoogd risico op kankersterfte of totale sterfte. Een tweede mogelijke verklaring is dat het leven in zulke wijken "stressvoller" is dan in andere wijken, en via vermindering van de weerstand tot meer sterfte zou leiden. Het is eveneens mogelijk dat mensen met een zwakkere algemene gezondheid via verminderde beroepskansen en dus minder inkomen disproportioneel in lagere SES-wijken aggregeren. De minder gunstige gezondheidsprognose van deze groep van mensen zou vervolgens de oversterfte in deze wijken althans gedeeltelijk kunnen verklaren. Tegen deze twee laatste verklaringen pleit het feit dat men dan wellicht ook een hogere sterfte aan hartziekte in deze woonwijken had kunnen verwachten, hetgeen in deze studie niet het geval was.

Tenslotte kan de indicator "woonwijk" verwijzen naar een andere indicator van sociaal-economische betekenis, namelijk inkomen. Deze indicator zou dan de relatie met het risico op sterfte verklaren. Het zou mogelijk kunnen zijn dat een hoger inkomen heeft geleid tot een betere behandeling bij ziekte, of tot eerdere diagnose van een chronische aandoening met als gevolg een betere secundaire preventie en prognose. Of 
zulke factoren een rol spelen binnen het bestel van het Nederlandse gezondheidszorgsysteem zou nader onderzocht moeten worden.

Samenvattend kan gesteld worden dat er in deze studie enige aanwijzingen gevonden zijn voor sociaal-economische gezondheidsverschillen. Deze verschillen bleven voornamelijk beperkt tot de omgevingsfactor van sociaal-economische status, namelijk woonwijk. Mensen die in de duurste wijken wonen blijken een verminderd risico op kankersterfte en totale sterfte te hebben. De verschillen in sterfterisico voor mensen uit andere woonwijken zijn minimaal. Enkele mogelijke verklaringen voor deze resultaten zijn aangegeven, die in deze studie niet nader onderzocht konden worden. Ze zouden onderwerp kunnen zijn van toekomstig onderzoek. 


\section{LITERATUUR}

1. Gunning-Schepers L, Spruit IP. Sociaal-economische gezondheidsverschillen: waarom in 1988 nog? Tijdschrift voor Sociale Gezondheidszorg 66: 303-304, 1988.

2. WRR. De ongelijke verdeling van gezondheid. Voorstudies en achtergronden V58. Staatsuitgeverij, 's Gravenhage 1987.

3. Glasunov I, Dowd E, Baubiniene A, et al. (eds.) The Kaunas-Rotterdam Intervention Study. Elsevier/North Holland Biomedical Press, Amsterdam 1981.

4. Weber M, Class, status en party. In: GHerth H, Mills W (eds.) From Max Weber: essays in sociology. Oxford University Press, New York 1946.

5. Shekelle RB, Ostfeld AM, Paul O. Social status and incidence of coronary heart disease. Journal of Chronic Disease 22: 381-394, 1969.

6. Holme I, Helgeland A, Hjermann I, et al. Coronary risk factors and socio-economic status: The Oslo study. Lancet 2: 1396-1398, 1976.

7. National Center for Health Statistics. Vital and Health Statistics, Series 10, No. 121. Characteristics of persons with hypertension, United Stated, 1974. DHEW Publication No. (PH) 79-1549. Washington DC, US GPO, November 1978.

8. Hypertension Detection and Follow-up Cooperative Group: Race, education and prevalence of hypertension. American Journal of Epidemiology 106: 351-361, 1977.

9. Haynes SG, Levine S, Scotch N, et al. The relationship of psychosocial factors to coronary heart disease in the Framingham Study. I Methods and risk factors. American Journal of Epidemiology 107: 362-382, 1978.

10. Jacobson BK, Thelle DS. Risk factors for coronary heart disease and level of education. The Tromso Heart Study. American Joumal of Epidemiology 127: 923$932,1988$.

11. Mackenbach JP, van der Maas PJ. IV Sociale ongelijkheid en verschillen in gezondheid: een overzicht van de belangrijkste onderzoeksbevindingen. In WRR, De Ongelijke Verdeling van Gezondheid. Voorstudies en achtergronden V58. Staatsuitgeverij, 's Gravenhage 1987.

12. van Reek J. Rookgedrag in Nederland van 1958-1982. Tijdschrift voor Alcohol en Drugs, 9: 99-103, 1983.

13. Kromhout D, Doombos G, Hoffmans MDAF. Voedselkeuze, leefwijze en sterfte in relatie tot opleiding. Tijdschrift voor Sociale Gezondheidszorg 66: 345-348, 1988.

14 NCHS-NHLBI Collaborative Lipid Group. Trends in serum cholesterol levels among U.S. adults aged 20 to 74 years. Data from the National Health and Nutrition Examination Surveys, 1960 to 1980. JAMA 257: 937-942, 1987.

15. Liu K, Cedres LB, Stamler J, et al. Relationship of education to major risk factors and death from coronary heart disease, cardiovascular diseases and all causes. Findings of three Chicago epidemiologic studies. Circulation 66: 1308-1314, 1982.

16. Kraus JF, Borhani NO, Franti ChE. Socio-economic status, ethnicity, and risk of coronary heart disease. American Journal of Epidemiology 111: 407-414, 1980. 
17. Marmot MG, Rose G, Shipley M, et al. Employment grade and coronary heart disease in British civil servants. Joumal of Epidemiology and Community Health 32: 244$249,1978$.

18. Thelle DS, Shaper AG, Whitehead TP, et al. Blood lipids in middle-aged British men. British Heart Joumal 49: 205-213, 1983.

19. Clark WB, Midanik L. Alcohol use and alcohol problems among US adults: results of the 1979 National Survey. In: Alcohol consumption and related problems. Alcohol and health monograph no. 1. National Institute of Alcohol Abuse and Alcoholism. Rockville MD, 1982.

20. Klatsky AL, Friedman GD, Siegelaub AB, et al. Alcohol consumption among white, black, or Oriental men and women: Kaiser Permanente multiphasic health examination data. American Journal of Epidemiology 105: 311-323, 1977.

21. Glynn RJ, de Labry LO, Hou DM. Alcohol consumption, Type A behavior, and demographic variables. Results from the Normative Aging Study. American Journal of Epidemiology 127: 310-320, 1988.

22. Millar WJ, Wigle DT. Socioeconomic disparities in risk factors for cardiovascular disease. Canadian Medical Association Joumal 134: 127-132, 1986.

23. Aro S, Raesaenen L, Telama R. Social class and changes in health-related habits in Finland in 1973-1983. Scandinavian Joumal of Social Medicine 14: 39-47, 1986.

24. Knibbe RA, Drop MI, van Reek J, et al. The development of alcohol consumption in the Netherlands: 1958-1981. British Journal of Addictions 80: 411-419, 1985.

25. Baecke JAH, Burema J, Frijters JER, et al. Obesity in young Dutch adults: I, socio demographic variables and body mass index. International Journal of Obsesity 7: 1$12,1983$.

26. Seidell JC, Bakx $\mathrm{KC}$, Deurenberg $\mathrm{P}$, et al. The relation between overweight and subjective health according to age, social class, slimming behavior and smoking habits in Dutch adults. American Joumal of Public Health 76: 1410-1415, 1986.

27. Rose G, Marmot MG. Social class and coronary heart disease. British Heart Journal 45: 13-19, 1981.

28. Marmot MG, McDowall ME. Mortality decline and widening social inequalities. Lancet 2: 274-276, 1986.

29. Pocock SJ, Shaper AG, Cook DG, et al. Social class differences in ischaemic heart disease in British men. Lancet 2: 197-201, 1987.

30. Jenkins CD. Psychosocial risk factors for coronary heart disease. Acta Medica Scandinavica 660 (Suppl): 123-136, 1982.

31. Morgenstem $\mathrm{H}$. The changing association between social status and coronary heart disease in a rural population. Social Science and Medicine 14A: 191-201, 1980.

32. Ruberman W, Weinblatt E, Goldberg JD, et al. Psychosocial influences on mortality after myocardial infarction. New England Journal of Medicine 311: 522-531, 1984.

33. Morgenstern H. Socioeconomic factors: concepts, measurement and health effects. In Ostfeld AM, Eaker ED (eds.) Measuring Psychosocial Variables in Epidemiologic Studies of Cardiovascular Disease. Proceedings of a Workshop. USDHHS, NIH Publication No. 85-2270, 1985. 
34. Jenkins CD. Psychologic and social precursors of coronary disease. New England Journal of Medicine 284: 244-255, 1971.

35. Pincus T, Callahan LF, Burkhauser RV. Most chronic diseases are reported more frequently by individuals with fewer than 12 years of formal education in the age 1864 United States population. Joumal of Chronic Disease 40: 865-874, 1987.

36. Lapidus L, Bengtsson C. Socioeconomic factors and physical activity in relation to cardiovascular disease and death. A 12 year follow-up of participants in a population study of women in Gothenberg, Sweden. British Heart Joumal 55: 295-301, 1986.

37. Siegel D, Kuller L, Lazarus NB, et al. Predictors of cardiovascular events and mortality in the Systolic Hypertension in the Elderly Program pilot project. American Journal of Epidemiology 126: 385-399, 1987.

38. Mackenbach JP. Regional differences in decline of mortality from selected conditions, The Netherlands, 1969-1984. In Mortality and Medical Care. Academisch Proefschrift, Rotterdam, 1988.

39. Marmot MG. Social class and mortality. Trends and explanations. Tijdschrift voor Sociale Gezondheidszorg 10: 315-320, 1988.

40. Kagamimori S, libuchi Y, Fox AJ. A comparison of socioeconomic differences in mortality between Japan and England and Wales. World Health Statistics Quarterly 36: 119-128, 1983.

41. Kitagawa EM, Hauser PM. Differential mortality in the United States. Harvard University Press. Cambridge MA, 1973.

42. Comstock GW, Tonascia JA. Education and mortality in Washington County, Maryland. Joumal of Health and Social Behavior 18: 54-61, 1977.

43. Hypertension Detection and Follow-up Program Cooperative Group. Educational level and 5-year all cause mortality in the Hypertension Detection and Follow-up Program. Hypertension 9: 641-646, 1987.

44. Devesa SS, Diamond EL. Socioeconomic and racial differences in lung cancer incidence. American Journal of Epidemiology 118: 818-831, 1983

45. Mares NEHM, Aben DJM, Schouten EG, et al. Inkomen en sterfte; resultaten van 25 jaar vervolgonderzoek bij mannelijke Amsterdamse ambtenaren. Nederlands Tijdschrift voor Geneeskunde 132: 1109-112, 1988.

46. Bos $\mathrm{T}$ van de, Lau-Yzerman A, Habbema JDF, et al. Ongezondheid in de grote stad. I. Medisch Contact 12: 335-340, 1980.

47. Appels A, Mulder $P$, van ' $t$ Hof $M$, et al. A prospective study of the Jenkins Activity Survey as a risk indicator for coronary heart disease in the Netherlands. Joumal of Chronic Disease 10: 959-965, 1987.

48. Beroepenklapper. Instituut voor Toegepaste Sociologie. Nijmegen, 1971.

49. SPSSX. McGraw-Hill. New York, 1986.

50. BMDP Statistical Sofware. University of Califomia Press. Los Angeles, 1985.

51. Rothman K. Modern Epidemiology. Little, Brown and Company. Boston/Toronto, 1986.

52. Statistical Yearbook 1983,1984. 34th ed. United Nations. New York, 1986. 
53. Fienberg SE. The analysis of cross-classified categorical data. MTT-press. Cambridge, 1981.

54. Gifi A. Nonliniair multivariate analysis. Department of Datatheory (RUL). Leiden, 1981 a.

55. Gifi A. HOMALS users guide. Department of Datatheory (RUL). Leiden, $1981 \mathrm{~b}$.

56. Brand-Koolen MJM. Factoranalyse in het sociologisch onderzoek. H.E. Stenfert Kroese N.V. Leiden, 1972.

57. Lee E. Statistical methods for survival data analysis. Lifetime Learning Publications. Belmont/California, 1980.

58. Kleinbaum DG, Kupper LL, Morgenstern H. Epidemiologic research: principles and quantitative methods. Lifetime Learning Publications. Belmont/California, 1982. 


\section{APPENDIX 1: MORBWITEITS-ENQUETE FOLLOW-UP ONDERZOEK}

\begin{abstract}
Vragenlijst over hartklachten
Op de volgende bladzijden staan een aantal vragen over hartklachten.

Misschien hebt $U$ de aigelopen 10 jaar (na 1972) harklachten gekregen, misschien ook niet. Wilt $U$ de volgende vragen over harklachten invullen? Bii elke vraag staan een aantal antwoorden. Lees elk antwoord goed door en kruis dat antwoord aan, dat het meest op $U$ van loepassing is.
\end{abstract}

Wij geven eerst een voorbeeld. Hebi $U$ de aigelopen 10 jaar ina 1972) last van pijn op de borst gekregen?

\section{$\square$ Ja \\ Nee \\ I $\mathrm{k}$ weet het niet zeker.}

Wanneer $U$ van Uzelf vindt, dat U pijn op de borst hebt gekregen, kruis dan 'ja' aan. Dus zo:

$\triangle$ la

Nee

I $k$ weel hel niet zeker.

Wanneer U van Uzelf vind, dat U geen pijn op de borst hebi gekregen, kruis dan 'nee' aan. Dus zo:

$\square$ la

$\triangle$ Nee

ik weet hel niet zeker.

Wanneer $U$ het niet mel Uzelf eens kunt worden, kruis dan 'ik weet het niet zeker' aan. Dus zo:

\section{$\square$ Nee \\ I I weet het niet zeker.}

U kunt bij elke vraag slechts éen hokje aankruisen.

Indien naam of adres onjuist is. wilt $U$ hier dan Uw juiste naam of adres invulten?

Naam ........

1 Hebt $U$ in de afgelopen 10 jaar (na 1972) ernstige harklachten gekregen?

Da la

2 Heeft een ants in de afgelopen 10 jaar (na 1972) tegen U gezegd. dat $U$ een hartiniarct hebt gehad? Ja

$\square$ Hij heeft gezegd. dat hij het niet precies wist.

E. Hel ging wel over mijn hart. maar ik weet niet wat hel was.

$\square$ Nee

Wanneer heet de ans dat te gen U gezegd?

Maand ..... laar

3 Door wie bent $U$ in de argelopen 10 jaar (na 1972) voor uw hant behandeld?

Ik ben niet voor mijn han behandeld.

Specialis!

Huisarts

Huisans en specialist

4 Wat zijn de naam en het adres van Uw huisarts?

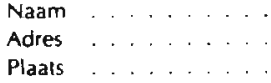

5 Indien $U$ in de ágelopen 10 jaar (na 1972) door een specialist voor Uw hart behandeld bent. wat is zijn naam?

Naam .... le ...

6 Bent $U$ in de algelopen 10 jaar (na 1972) voor Uw han in een ziekenhuis opgenomen geweest?

$\square$ la

Nee

Zoja, in welk ziekenhuis en wanneer ongeveer?

le opname:

ziekenhuis ... te

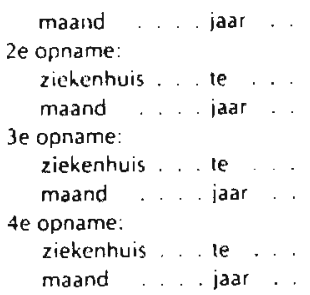

7 Hebl $U$ in de afgelopen 10 jaar (na 1972) een hartoperatie onder. gaan?

Zlla

Zo ja, wanneer?

in welk ziekenhuis? . . te

8 Hebt $\mathrm{U}$ in de afgelopen 10 jaar (na 1972) een hartcathelerisatie ondergaan?

Ela

Dee

Ik weet niel wat dat is

20 ja, wanneer?

In welk riekenhuis? ... te

9 Bent $U$ in de ágelopen 10 jaar (na 1972 ) wegens een beroente of hersenbloeding opgenomen geweest in een ziekeninuis?

$\square$ la

Nee

Zo ja, wanneer?

in weik ziekenhuis? .... te

10 Rook! U thans sigaretten? 7 la

Nee

Zo ia hoeveel sigaretten rookt $U$ gewoontijk per dag?

- sigaretten per dag.

11 Rookt U pipp of siguar?

Alleen pijp

Alleen sigaar

Pijp en sigaar

Geen pijp. geen sigaar

12 Crebruiki $U$ wel eens rnedic? nen tegen pijn op de borst?

\section{ha}

Nee

Ith gebruik wel medicijnen. mar ik weel niet of ze daarvoor dienen

Hoe heel dat geneesmiddel?

13 Cebruikt U een bloedverdun. nend middel (sintrom, marcoumar of sinirommilis)?

\section{Ja}

Nee

14 Vind $U$ het goed als wij, in dien nodig, nadere medische iniormatie aan Uw huisans vargen?

$\square_{\text {Nee }}$

Ja, op voorwaarde dat

is Vindi $U$ het goed als wij, in dien nodig. nadere medische iniomatic aan Uw specialis vrage?n?

$\square$ Ia
$\square$ Nee
$\square$ la, op voorwaarde dal

16 Hebi U nog bepaalde opmes kingen?

Datum Handtekening Hartelijk dank voor Uw medewer. king. 


\section{APPENDIX 2: CODERING MYOCARDINFARCT, CORONAIR- LIJDEN EN CVA}

\author{
I Myocardiniarct \\ Op basis van gegevens over anamnese, elektrocardiogram en \\ enzymwaarden (verzameld via specialistenbrieven) wordt bij ie- \\ dere verdenking op myocardinfarcl een aantal punten toege- \\ kend.
}

A. Sconingscriteria voor Anamnese, ECG en Enzwmwaarden Anamnese

Pın op de borst +2 hieronder genoemde kenmerken

2 punten

Pijn op de borst +1 hieronder genoemd kenmerk

1 punt

Kenmerken: plotselıng begin of toename niet gebonden aan inspanning duur langer dan 30 minuten krampend of drukkend karakter uitstraling geen reactie op nitrobaat Indien aan geen van deze criteria wordt voldaan

0 punten

Elektrocardiogram

Aanwezigheid van de 'injury current' zonder meer:

en/of Minnesotacode 1.1 of $1.21 \mathrm{Q}$

golfafwijkingen

en/of 7.1 (linker bundeltakblok) indien het een eerste iniarct betrof.

en/of de beschrijuing van het ECG door de behandelend specialist als typisch voor myocardinfarci

2 punten

\section{Minnesotacode 1.3 (geringe Q}

goliaiwijkingen)

en/of 5.1 of 5.2 (negatieve $T$ toppen)

en/oi beschrijuing van het ECG door de behandelend specialist ais verdacht voor myocardinfarci

1 punt

Indien aan geen van deze criteria wordt voldaan

0 punten

Enzymwaarden

Indien zowel de waarde van SCOT als van

CPK hoger was dan de in het betrefiende ziekenhuis op dat tijdsup geldende normaalwarde

2 punlen

Indien or de waarde van SGOT of de waarde van CPK hoger was dan de eerder genoemde bovengrens.

en/ot er een enzymwaardenverloop.

verdacht voor myocardiniarct aanwezig was i punt
Indien aan geen van deze criteria wordı voldaan

0 punten

B. Codering

Aan de hand van het verkregen puntenaantal wordt en van de volgende codes toegekend:

- mogelikk mrocardiniarci

- waarschijnlijk myocardinfarcl

- zeker myocardiníarct

1 Bij aanwezigheid van gegevens over anamnese, ECG en enzymen word t als volgt gecodeerd:

0-1 punt geen infarct

$2-3$ punten mogelijk iniarct

4 punten waarschijnlijk infarct

5.6 punten zeker infarct

In het geval dat de gegevens over anamnese, enzymwarden en/of ECG arwezig zijn, wordt een afwijkend schema gevolgd.

2 Bij aanwezigheid van gegevens over 2 van deze 3 critena wordt gecodeerd

$$
\begin{aligned}
& \text { 0-1 punt geen infarct } \\
& 2 \text { punten mogelijk iniarct } \\
& 3-4 \text { punten waarschijnlijk infarct }
\end{aligned}
$$

3 Wanneer alleen de kliniekdiagnose myocardinfarct aanwezig is. wordt (op basis van het artikel van H.N. Hart e.a.)" gecodeerd: waarschijnlijk iniarct

\section{"Coronairlijiden}

Respondenten welke 1 of meer ntyocardinfarcten enfor bypass operatie hebben doorgemaakt, ontvangen bij coronairlijden (angina pectoris) allemaal de code: niet van roepassing.

Er wordt gecodeerd op basis van bij de huisants aanwezige gegevens over anamnese, elekırocardiogram, afwijkingen tijdens pijn, inspanningsonderzoek, hartcatheterisatie en corona. ry-bypass operatie. Vaak zijn slechts enkele van de hierboven genoemde onderzoeken verricht. De beoordeling van deze onderzoeken door de behandelend specialist is overgenomen.

Aan de hand van het hieronder vermelde schema wordt een van de volgende codes loegekend:

\section{- anamnese positiei voor coronairlijden en zeker}

afwijkende hancathelerisatie

coronairlijden

- anamnese positier voor coronairlijden en

ECC-afwijkngen bii pijn en of afwijkend

waarschipnliji inspanningsonderzoek coronairlıjden

- anamnesr. positiet voor coronairlijden

mogeli,k coronarliden

III CVA

Er wordt gecodeerd op basis van gegevens van de behandelen. de hussans/specialıst. Indien zij de diagnose CVA of TIA hadden gesteld, word gecodeerd: CVA: $j$.

- HN Hart ea Vergehiking van de coronarv care unit-onislagdiagnose acuut myocardinfarct mel een volgens WCO-richilinen objectiet gersteide standaarddiagnove Suppl i bit nr. 22 T.Soc Geneesh. 55(1977)25-27 


\section{APPENDIX 3: HET LOG-FREQUENTIEMODEL}

Het log-frequentiemodel voor een twee-dimensionele kruistabel baseert zich op de rationale dat de natuurlijke logaritme van elke celfrequentie is opgebouwd uit de volgende uniek te bepalen additieve componenten:

- Een aigemeen gemiddelde. Dit is het rekenkundig gemiddelde van alle logaritmische celfrequenties.

- Twee zogenaamde $1^{\mathrm{e}}$-orde effecten ofwel hoofdeffecten. Het ene hoofdeffect wordt uitgedrukt door de deviatie van het algemene gemiddelde met het gemiddelde van overeenkomstige logaritmische rij-frequenties. Het andere hoofdeffect wordt uitgedrukt door de deviatie van het algemene gemiddelde met het gemiddelde van overeenkomstige logaritmische kolomfrequenties.

- Een zogenaamd $2^{c}$-orde interactie-effect. Dit is de deviatie van de desbetreffende logaritmische celfrequentie met de som van de bij deze cel behorende hoofdeffecten en het algemeen gemiddelde.

Op basis van de beschreven effectparameters kunnen de oorspronkelijk geobserveerde celfrequenties exact worden gerepliceerd. Omdat in deze situatie het aantal vrije parameters gelijk is aan het aantal cellen van de tabel spreekt men ook wel van een verzadigd $\log$-frequentie model. Met log-frequentie-analyse is het mogelijk om na te gaan of ook een beperkter model (een model met een geringer aantal parameters) in staat is om de geobserveerde celfrequenties op adekwate wijze te voorspellen. Bij een beperkter model kunnen de parameters niet meer uniek bepaald worden maar moeten ze volgens een bepaald criterium geschat worden. Een veel gebruikt criterium hierbij is het principe van de grootste aannemelijkheid ofwel de maximum likelihood procedure. Bij een tweedimensionele kruistabel ligt het voor de hand om na te gaan of een model met alleen schattingen voor het algemene gemiddelde en voor de hoofdeffecten de geobserveerde celfrequenties adekwaat voorspelt. Adekwaatheid van een dergelijk gerestricteerd model betekent immers dat de twee variabelen niet samenhangen. De statistische toetsing van een dergelijk model geschiedt met behulp van een likelihoodratio-test. De likelihoodratio is bij benadering chi-kwadraat verdeeld. In zijn algemeenheid levert de constatering van een statistisch significante samenhang tussen twee multipele categorische variabelen nogal problemen voor verdere inhoudelijke interpretatie. Een groot voordeel van het log-frequentiemodel is dat bij een eventuele statistisch significante samenhang inzichtelijk kan worden gemaakt van welke specifieke categorieen-combinatie(s) deze significantie afkomstig is. Het logfrequentiemodel levert immers de parameters van de $2^{\mathbf{c}}$-orde interactie-effecten met de daarbij behorende standaardfouten zodat met behulp van een Z-toets eenvoudig kan worden vastgesteld welke categorië̈ncombinatie(s) de belangrijkste bijdrage(n) voor de geconstateerde samenhang leveren. Voor meer informatie over log-lineaire modellen wordt verwezen naar Fienberg (52). 


\section{APPENDIX 4: DE CONSTRUCTIE VAN DE SES-INDEX}

Een belangrijke assumptie van multivariate analysetechnieken is de lineariteit van de (bivariate) associaties tussen de betrokken variabelen. Aangezien de categoriewaarden van multipele categorische variabelen niet lineair zijn geordend, komen dergelijke nominale variabelen niet in aanmerking voor de gebruikelijke lineaire technieken. Een oplossing voor deze moeilijkheid wordt door het, door de universiteit van Leiden ontwikkelde, HOMALS-programma $(53,54)$ aangereikt. HOMALS staat voor "HOMogenity analysis by

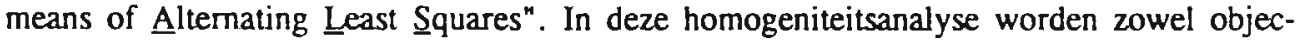
ten (de onderzoekseenheden) als categorieën volgens een afwisselend kleinste kwadratenalgorithme gekwantificeerd. De dimensionaliteit $\mathrm{p}$ van de kwantificering dient door de onderzoeker zelf te worden opgegeven. De objectscores zijn nu $\mathrm{n}$ punten in de p-dimensionele ruimte (dus op een lijn als $p=1$ en in een plat vlak als $p=2$ ). De categoriekwantificeringen (voor variabele $\mathrm{j}$ met kj categorieën) zijn kj punten in deze p-dimensionele ruimte. Elk categoriepunt is het middelpunt (het graviteitscentrum) van de objectpunten behorende tot de betreffende categorie. Homogeniteits-analyse schat de objectscores zodanig dat de objecten behorende tot eenzelfde categorie relatief dicht bij elkaar en objecten van andere categorieën relatief ver van elkaar komen te liggen. De analyse streeft ernaar om voor alle variabelen tezamen een zo maximaal als mogelijke homogeniteit te bewerkstelligen. Een belangrijke maat in deze context is de zogenaamde discriminerende waarde van een variabele. Deze discriminerende waarden staan voor de gekwadrateerde itemtotaaicorrelaties van de variabelen met de desbetreffende dimensie en zijn in zeker opzicht vergelijkbaar met de van PCA (principale componentenanalyse) zo bekende componentladingen. Een hoge discriminerende waarde geeft aan dat de categorieèn van de betreffende variabele voor een bepaalde dimensie adequaat van elkaar zijn onderscheiden. Het gemiddelde van de discriminerende waarden is gelijk aan de eigenwaarde van de desbetreffende dimensie. De eigenwaarden kunnen bij HOMALS variëren tussen het minimum 0 en het maximum 1. Een eendimensionele HOMALS-oplossing kenmerkt zich door twee nuttige eigenschappen. Allereerst geldt dat de eigenwaarde behorende tot de eerste dimensie maximaal is, verder worden voor deze eerste dimensie de nominale variabelen zodanig getransformeerd dat ze door de categoriekwantificeringen een metrisch meetniveau krijgen die bij benadering normaal verdeeld is. De aldus gecreëerde intervalvariabelen kunnen nu voor lineaire statistische procedures zoals regressie-analyse of factoranalyse gebruikt worden. Gifi omschrijft een dergelijk gebruik van HOMALS als "using HOMALS as a first step".

Ter kwantificering van de vijf SES-indicatoren is een eendimensionele HOMALSanalyse uitgevoerd. Vervolgens werden de gekwantificeerde SES-indicatoren gefactoranalyseerd om na te gaan of aan deze indicatoren daadwerkelijk een unidimensioneel construct ten grondslag ligt. Factoranalyse is een lineaire reductietechniek die op basis van een variantie maximaliserend principe een bepaalde set van variabelen transformeert naar een kleiner aantal nieuwe (onderling onafhankelijke) variabelen. Deze nieuwe variabelen worden factoren genoemd. Wanneer de oorspronkelijke variabelen door één factor gere- 
presenteerd kunnen worden is er sprake van een unidimensionele oplossing. Belangrijke output bij factoranalyse zijn de factorladingen. Dit zijn de gewichten die nodig zijn voor de constructie van de variabelen uit de factoren. De som van de gekwadrateerde factorladingen is gelijk aan de eigenwaarde van de desbetreffende factor. De eigenwaarde geeft aan hoeveel variantie van de variabelen door de desbetreffende factor wordt verklaard. Een eigenwaarde die kleiner is dan 1 wordt vaak als criterium gebruikt om met factorextractie te stoppen. Voor uitgebreidere informatie omtrent factoranalyse wordt verwezen naar Brand-Koolen (56).

In de eerste tabel worden de resultaten van de HOMALS-kwantificering gepresenteerd. De tabel laat zien dat de oorspronkelijke categorieênindeling van initieel beroepsniveau en opleidingsniveau slechts voor een deel door een ordinale rangschikking worden gekenmerkt. De discriminerende waarden van alle gekwantificeerde SES-indicatoren zijn zonder meer hoog te noemen. Aangezien het gemiddelde van de discriminerende waarden gelijk is aan de HOMALS-eigenwaarde, werd in de onderhavige analyse logischerwijs een hoge eigenwaarde (.70) vastgesteld. Deze resultaten duiden op adekwaatheid van de HOMALS-toepassing. In deze context moet nog een technische opmerking over het HOMALS-programma worden gemaakt. De capaciteit van dit programma (wij gebruikten de GIFI-versie uit 1981) is nogal beperkt. Het was daarom niet mogelijk om HOMALS in een keer op alle 3365 KRIS-participanten toe te passen. Er zijn daarom dertig aselecte steekproeven van 1000 KRIS-participanten uit de oorspronkelijke steekproefpopulatie getrokken. Op deze dertig aselecte substeekproefpopulaties werden vervolgens evenveel HOMALS-analyses uitgevoerd. De in de eerste tabel gepresenteerde categoriekwantificeringen en discriminerende waarden representeren de gemiddelden van telkens dertig overeenkomstige (overigens zeer stabiele) HOMALS-oplossingen.

Op grond van de HOMALS-categorie kwantificeringen kunnen de vijf SES-indicatoren als continue en bij benadering normaal verdeelde variabelen worden beschouwd. Ter verkrijging van een SES-index is op de gekwantificeerde SES-indicatoren factoranalyse toegepast. De resultaten van deze analyse staan in de tweede tabel. Zoals in de tabel wordt aangegeven, leverde factoranalyse een eenduidige eenfactoriële oplossing. De eigenwaarden van de overige geëxtraheerde factoren waren allemaal kleiner dan .5 en konden derhalve zonder meer worden weggelaten. De communaliteiten (dit zijn de gekwadrateerde factorladingen) geven aan welke delen van de variabelen met de onderliggende factor gemeenschappelijk zijn. De gemeenschappelijkheid is in dit geval groot, liefst $70.3 \%$ van de variantie van de SES-indicatoren wordt door die ene factor verklaard. Deze factor wordt beschouwd als het aan de vijf SES-indicatoren ten grondslag liggende unidimensionele construct sociaal-economische status. Met behulp van de factorscores is een SES-index geconstrueerd zoals die in tabel 1.2 .8 omschreven wordt. 
Appendix 4 HOMALS-categorie kwantificeringen voor de SES-indicatoren initieel beroep, huidig beroep, beroep vader, opleiding en SES-wijk.

\begin{tabular}{|l|r|r|r|}
\hline & Initieel beroep & Huidig beroep & Beroep vader \\
\hline ongeschoolde arbeid & -.47 & -.72 & -.68 \\
geschoolde arbeid & -.47 & -.65 & -.47 \\
Lagere employee & .86 & -.16 & .04 \\
Kleine zelfstandige & .36 & .04 & .28 \\
Middelbare employee & 1.87 & .65 & .97 \\
Hoger beroep & 2.74 & 1.91 & 2.11 \\
Discriminerende waarde & & .68 & .76 \\
\hline
\end{tabular}

\begin{tabular}{|l|c|}
\hline & Opleiding $^{*}$ \\
\hline LO & -.61 \\
LO + partime onderwijs & -.41 \\
LBO & -.49 \\
LBO + aanvullend onderwijs & -.41 \\
ULO & .41 \\
ULO + aanvullend onderwijs & .52 \\
VAMO/middelbaar beroepsonderwijs & 1.23 \\
HBO & 1.60 \\
Universiteit & 2.52 \\
Discriminerende waarde & \\
\hline
\end{tabular}

\begin{tabular}{|l|c|}
\hline & SES-wijk \\
\hline laag & -.65 \\
laag-midden & -.51 \\
hoog-midden & -.28 \\
hoog & 1.44 \\
Discriminerende waarde & .68 \\
\hline
\end{tabular}

- De categorieën van opleidingsniveau worden in afgekorte vorm weergegeven. Voor de exacte operationalisering verwijzen we naar tabel 1.2.6. 
Appendix 4 De resultaten van factoranalyse op de gekwantificeerde SES-indicatoren initieel beroep, buidig beroep, beroep van vader, opleiding en SES-wijk

\begin{tabular}{|l|l|l|l|l|l|}
\hline Variabele & $\begin{array}{l}\text { Commu- } \\
\text { naliteit }\end{array}$ & factor & eigenwaarde & $\begin{array}{l}\text { \% verklaarde } \\
\text { variantie }\end{array}$ & factorladingen: \\
\hline initieel beroep & .6865 & 1 & 3.52 & 70.3 & .8286 \\
actueel beroep & .7593 & & & & .8714 \\
beroep vader & .5798 & & & & .7615 \\
opleiding & .8200 & & & & .9056 \\
SES-wijk & .6699 & & & & .8185 \\
\hline
\end{tabular}




\section{APPENDIX 5: LOGISTISCHE REGRESSIE EN COX REGRESSIE}

Zowel logistische als Cox regressieanalyse zijn in feite non-parametrische technieken. Dit betekent dat niet verondersteld wordt dat een normaalverdeling aan zowel de afhankelijke als de onafhankelijke variabelen ten grondslag ligt. Beide technieken hebben het voordeel dat ze zowel continue als (multipele) categorische variabelen als onafhankelijke variabelen kunnen hanteren. De (multipele) categorische variabelen moeten dan wel in een aantal nieuwe zogenaamde dummy-variabelen worden omgezet. Dit geschiedt door een bepaalde referentiecategorie te kiezen waartegen dan telkens de overige categorieën afzonderlijk worden afgezet. Van een multipele categorische variabele met $k$ categorieên kunnen derhalve k-1 onderling afhankelijke dummy-variabelen worden gecreëerd. Aangezien deze dummy's tezamen de desbetreffende categorische variabele representeren dienen zij ook steeds als een geheel in de statistische toetsingsprocedure (een likelihoodratio-test) betrokken te worden.

Voor beide modellen geldt dat de antilogaritme van de geschatte partiēle regressiecoëfficiënten (de term antilogaritme betekent dat de regressie-coëfficiënt als exponent van het grondgetal e moet worden genomen) benaderingen zijn voor een belangrijke epidemiologische effectmaat, het zogenaamde gecorrigeerde relatieve risico. Het relatieve risico is een kansverhouding en drukt bijvoorbeeld uit hoeveel groter maal het infarctrisico van een arbeider is in vergelijking tot iemand die een hoger beroep uitoefent. De term gecorrigeerd betekent dat er gecorrigeerd is voor de invloed van andere onafhankelijke variabelen die zowel met de betrokken als de afhankelijke variabele samenhangen (zogenoemde confounders). In tegenstelling tot het logistische regressiemodel waarbij als afhankelijke variabele de cumulatieve incidentie van het desbetreffende eindpunt wordt genomen, wordt de afhankelijke variabele bij Cox regressie uitgedrukt door de tijd totdat er een bepaald eindpunt optreedt. Als dit eindpunt niet optreedt wordt als waarde voor de afhankelijke variabele de gehele follow-up duur genomen. Een dergelijke waarneming wordt bij de overlevingsanalyse (tot dit type analyse-technieken behoort het Cox model) een gecensureerde waarneming genoemd. Omdat in het Cox regressie-model ook de variabele fo]low-up tijd wordt meegenomen verdient dit model vanwege de betrouwbaardere parameterschattingen de voorkeur boven logistische regressie. Nu ligt aan het Cox regressiemodel de belangrijke "proportional hazard" assumptie ten grondslag. Deze assumptie stelt dat de ratio van de hazard rates voor de verschillende niveaus van een onafhankelijke variabele constant in de tijd blijft. Deze assumptie is apart voor alle onafhankelijke variabelen getoetst met behulp van zogenoemde tijdsafhankelijke covariaten. Deze procedure behelst dat in het Cox regressiemodel naast één bepaalde onafhankelijke variabele ook de interactie tussen deze variabele en de follow-up tijd (interactie = multiplicatie van de betrokken variabele met de tijdsvariabele, deze nieuwe variabele wordt met de benaming covariaat aangeduid) wordt opgenomen. Vervolgens wordt de geschatte regressie-coēfficiēnt van de covariaat getoetst op statistische significantie. Een statistisch significante regressie-coëfficiënt betekent dat de "proportional hazard" assumptie wordt geschonden. Het model mag dan toch gebruikt worden onder voorwaarde dat de betreffende covariaat als extra varia- 
bele aan het model wordt toegevoegd. Non-significantie van de regressiecoêfficiēnt betekent dat het model zonder de covariaat zonder meer gebruikt kan worden. Voor verdere informatie over Cox regressieanalyse en logistische regressieanalyse wordt verwezen naar Lee (56) en Kleinbaum e.a. (57). 



\title{
HOOFDSTUK 2 De KRIS follow-up study II: Burgerlijke staat en sterftekans
}

\author{
(A. Appels, F.Otten, F. Sturmans, P. Mulder)
}

(T. Soc. Gezondheidsz. 1988; 66: 67-69)

In deze studie werd met behulp van de gegevens verkregen in de KRIS followup study onderzocht of er verschillen bestaan in mortaliteit, met name cardiale mortaliteit, tussen mannen met een verschillende burgerlijke staat. De sterftekans van alleenstaande mannen bleek over de 9,5 jaar follow-up periode 2.48 maal groter te zijn dan die van gehuwde mannen, terwijl het risico op overlijden ten gevolge van een hartinfarct bij hen 2.77 maal groter was. Bij controle op relevante risicofactoren zijn deze relatieve risico's respectievelijk 2.61 en 2.80. Geen significante verschillen in sterfiekans werden gevonden tussen gehuwde mannen enerzijds en weduwnaars of gescheiden mannen anderijds. De kans om aan een hartinfarct te sterven is bij weduwnaars echter driemaal groter dan bij gehuwde mannen. De resultaten worden gelinterpreteerd in het kader van een social-support theorie.

\subsection{INLEIDING}

In verschillende Amerikaanse en in enkele Europese studies is in de afgelopen jaren geconstateerd, dat het behoren tot een hecht sociaal netwerk de sterftekans vermindert (Wingard 1982, Koskenvuo 1980). In deze studies is het concept sociaal netwerk op verschillende manieren geoperationaliseerd. Zo gebruiken Koskenvuo e.a. enkel burgerlijke staat als indicator voor het sociale netwerk. House (1982) en Wingard (1982) gebruikten meerdere indicatoren voor het sociale netwerk. Zij maken een onderscheid tussen sociale relaties (waaronder burgerlijke staat), institutionele betrokkenheid en actieve en passieve ontspanningsactiviteiten. Beide studies constateerden, dat bij mannen het kenmerk burgerlijke staat, en wel de vergelijking van niet-gehuwde mannen met gehuwde mannen, van alle netwerk indicatoren de sterkste predictieve waarde voor mortaliteil had.

In de cardiovasculaire epidemiologie is de burgerlijke staat ook in de aandacht gekomen door de bevinding van Parkes (1969), Rees (1967) en Cottington (1980) dat zij die hun partner verliezen een grotere (cardiale) sterftekans hadden binnen een jaar na het verlies van hun partner. Genoemde onderzoekers schrijven deze oversterfte toe 
aan de verlies-ervaring. Het verlies van de partner zou de sterftkans vooral op korte termijn sterk verhogen. Het is echter ook denkbaar dat dit risico langdurig verhoogd blijft door de schade, die door het wegvallen van de partner aan het sociale netwerk is toegebracht.

In de Kaunas-Rotterdam Intervention Study (KRIS) deed zich de mogelijkheid voor om in een prospectief design na te gaan of ook in Nederland de sterftekans geassocieerd is met de burgerlijke staat.

\subsection{METHODEN}

Tussen 1972-1974 participeerden 3365 Rotterdamse mannen van 45-60 jaar in een cardiovasculair screeningsprogramma. Dit onderzoek omvatte ondermeer een meting van bloeddruk, cholesterol, roken en glucose tolerantie. De burgerlijke staat werd vastgelegd in de categorieën: gehuwd, ongehuwd, weduwnaar, gescheiden. In 1981 werd nagegaan welke participanten een al dan niet fataal hartinfarct gekregen hadden of aan een andere doodsoorzaak waren overleden. Tijdens deze follow-up periode van ongeveer 9,5 jaar bleken 350 personen overleden te zijn, waarvan 112 aan een hartinfarct. De details van het screeningsonderzoek zijn elders uitvoerig beschreven. (Glasunov 1981, Appels 1988)

Met logistische regressies werd met betrekking tot de (cardiale) mortaliteit allereerst het predictief vermogen van de burgerlijke staat van de factoren, welke als potentiële confounders in aanmerking komen, voor iedere variabele apart berekend. Voor totale mortaliteit zijn deze factoren respectievelijk: leeftijd, roken (gecodeerd als roken - niet roken) en beroepsniveau (ongeschoolde arbeiders, geschoolde arbeiders, employees). Bij de berekeningen over de cardiale mortaliteit werden hier diastolische bloeddruk, plasma cholesterol en plasma glucose aan toegevoegd. Vervolgens werden multivariate logistische regressies uitgevoerd om het effect van iedere variabele, gecontroleerd voor alle andere in het model opgenomen variabelen, te bepalen en na te gaan of er interacties optraden tussen burgerlijke staat en één van de risico-indicatoren op sterftekans. Voor deze analyses werd gebruik gemaakt van het logistische model, omdat dit multiple categorische variabelen (middels dummificatie) kan hanteren bij handhaving van het meetniveau van continue variabelen (Kleinbaum 1982). De logistische regressie analyses zijn uitgevoerd met de LR-procedure van het BMDP pakket. 


\subsection{RESULTATEN}

\section{Ruwe vergelijking van sterftkansen (zonder correctie)}

Alleenstaande mannen hebben in vergelijking tot gehuwde mannen een significant verhoogde sterftekans, zowel voor totale mortaliteit als cardiale mortaliteit. De ruwe relatieve risico's zijn respectievelijk 2.48 en 2.77 . Weduwnaren hebben in vergelijking met gehuwden een grotere kans op cardiale mortaliteit. Geen verschillen werden gevonden wanneer gescheiden mannen met gehuwde mannen werden vergeleken (tabel 1).

Tabel 1 Ruwe relatieve risico's voor totale mortaliteit en cardiale mortaliteit bij alleenstaanden, weduwnaars en gescheiden mannen in vergelijking tot gehuwde mannen

\begin{tabular}{|l|cc|cr|}
\hline & \multicolumn{3}{|c|}{ Totale mortaliteit } & \multicolumn{2}{c|}{ Cardiale mortaliteit } \\
& RR & $90 \% \mathrm{BI}$ & $\mathrm{RR}$ & $90 \% \mathrm{BI}$ \\
\hline Alleenstaand & 2.48 & $1.82-3.38$ & 2.77 & $1.51-5.10$ \\
Weduwnaar & 1.53 & $.83-2.80$ & 3.13 & $1.14-8.57$ \\
Gescheiden & 1.28 & $.83-1.99$ & .77 & $.24-2.57$ \\
\hline
\end{tabular}

Naast leeftijd en roken blijkt ook een laag beroep de sterftekans nadelig te beïnvloeden. In vergelijking tot employees hebben ongeschoolde arbeiders een statistisch significant hogere sterftekans $(R R=1.35)$. Het risico op cardiale mortaliteit blijkt samen te hangen met cholesterol, leeftijd en diastolische bloeddruk. Rokers hebben in vergelijking tot niet-rokers een grotere cardiale sterftekans, echter dit verband is statistisch niet significant. Er werden geen samenhangen gevonden tussen beroepsniveau en plasma glucose enerzijds en cardiale mortaliteit anderzijds (tabel 3).

Tabel 2 Predictoren totale sterfte (ongecorrigeerd)

\begin{tabular}{|l|c|c|c|c|}
\hline Variabele & Regressiecoefficient & Standard error & RR & 90\% BI \\
\hline Alleenstaand-gehuwd & .909 & .188 & 2.48 & $1.82-3.38$ \\
Weduwnaar-gehuwd & .425 & .368 & 1.53 & $.83-2.80$ \\
Gescheiden-gehuwd & .250 & .266 & 1.28 & $.83-1.99$ \\
\hline Rokers-niet rokers & .361 & .129 & 1.43 & $1.16-1.77$ \\
\hline Ongeschoolde arbeiders-employees & .303 & .121 & 1.35 & $1.11-1.65$ \\
Geschoolde arbeiders-employees & .180 & .191 & 1.20 & $.87-1.64$ \\
\hline Leeftijd* & .114 & .014 & 3.13 & $2.48-3.94$ \\
\hline
\end{tabular}

Het relatieve risico is bier zo berekend, dat het de stijging in risico uitdrukt wanneer de leeftijd met 10 jar toeneemt. 
Tabel 3 Predictoren cardiale mortaliteit (ongecorrigeerd)

\begin{tabular}{|l|c|c|c|c|}
\hline Variabele & Regressie coefficient & Standard error & RR & $90 \%$ BI \\
\hline Alleenstaand-gehuwd & 1.02 & .370 & 2.77 & $1.51-5.10$ \\
Weduwnaar-gehuwd & 1.14 & .613 & 3.13 & $1.14-8.57$ \\
Gescheiden-gehuwd & -0.25 & .726 & .77 & $.24-2.57$ \\
\hline Rokers-niet rokers & .32 & .277 & 1.38 & $.87-2.17$ \\
\hline Ongeschoolde arbeiders-employees & - & - & - & - \\
Geschoolde arbeiders-employees & - & - & - & - \\
\hline Leefijd * & .048 & .028 & 1.62 & $1.02-2.56$ \\
\hline Diastolische bloeddruk* & .02 & .010 & 1.18 & $1.01-1.39$ \\
\hline Cholesterol & .01 & .003 & 1.10 & $1.05-1.16$ \\
\hline Plasma glucose & - & - & - & - \\
\hline
\end{tabular}

* Het relatieve risico is hier zo berekend dat bet de toename van het risico uitdrukt wanneer de leeftijd met $10 \mathrm{jaar}$, de diastolische bloeddruk met $10 \mathrm{mmHg}$ en het cholesterol met $10 \mathrm{mg} / 100 \mathrm{ml}$ toeneemt.

\section{Vergelijking met gecorrigeerde sterftekansen}

In geen van de multivariate analyses werden significante interactie-effecten tussen burgerlijke staat en één van de risico-indicatoren op de totale of de cardiale sterfte geconstateerd. De effecten van de burgerlijke staat worden dus niet gemodificeerd door één van de gespecificeerde risico-indicatoren.

De multivariate analyses tonen, dat ook na controle voor de boven gespecificeerde variabelen, alleenstaanden een grotere sterftekans hebben dan gehuwden. Rekening houdend met de invloed van leeftijd, beroepsniveau en roken op de sterftekans blijken alleenstaanden een 2.61 keer zo grote kans te hebben om binnen de follow-up periode te sterven dan gehuwde mannen. De lichte stijging van het aangepaste relatieve risico ten opzichte van het ruwe relatieve risico wijst erop, dat de variabelen leeftijd en roken de ongecorrigeerde associatie enigermate onderdrukt hebben, wat veroorzaakt wordt door een hogere gemiddelde leeftijd en meer rokers in de groep van gehuwde mannen. Opvallend is, dat de significante ruwe associatie tussen beroepsniveau en totale sterfte door de gelijktijdige werking van burgerlijke staat en van de genoemde confounders volledig wordt wegverklaard. Tenslotte blijkt, dat in het multivariate model weduwnaars en gescheiden mannen geen duidelijk verhoogde sterftekans hebben (tabel 4). 
Tabel 4 Relatief risico voor totale mortaliteit voor alleenstaande of gescheiden mannen en weduwnaars in vergelijking tot gehuwde mannen gecontroleerd voor leeftijd, roken en beroepsniveau.

\begin{tabular}{|l|c|c|}
\hline & RR & $90 \%$ betrouwbearheidsinterval \\
\hline Alleenstaand-gehuwd & 2.61 & $1.91-3.57$ \\
Weduwnaar-gehuwd & 1.15 & $.61-2.18$ \\
Gescheiden-gehuwd & 1.27 & $.81-1.98$ \\
\hline
\end{tabular}

Alleenstaanden en weduwnaars blijken ook een hoger risico op cardiale mortaliteit te hebben dan gehuwden. De voor de invloed van de eerder genoemde risicofactoren aangepaste relatieve risico's zijn vrijwel gelijk aan de ruwe relatieve risico's, namelijk 2.80 voor alleenstaanden en 3.03 voor weduwnaars (tabel 5).

Tabel 5 Relatief risico voor cardiale mortaliteit voor alleenstaande of gescheiden mannen en weduwnaars in vergelijking tot gehuwde mannen gecontroleerd voor leeftijd, roken, cholesterol, plasma glucose, bloeddruk en beroepsniveau.

\begin{tabular}{|l|r|c|}
\hline & $R R$ & $90 \%$ betrouwbaarbeidsinterval \\
\hline Alleenstaand-gehuwd & 2.80 & $1.52-5.14$ \\
Weduwnaar-gehuwd & 3.03 & $1.11-8.27$ \\
Gescheiden-gehuwd & .74 & $.22-2.46$ \\
\hline
\end{tabular}

\subsection{DISCUSSIE}

De resultaten van dit onderzoek laten zien, dat alleenstaande mannen in vergelijking tot gehuwde mannen een 2.61 maal zo grote kans hebben om binnen 10 jaar te sterven en een 2.81 maal zo grote kans om aan een hartinfarct te overlijden. Deze sterftekansen zijn in principe onafhankelijk van leeftijd en klassieke risicofactoren als bloeddruk en cholesterol.

Dit verhoogde risico was voorspeld vanuit een sociale netwerktheorie, die aangeeft, dat zij die in een sociaal isolement leven een verhoogd risico hebben op met name cardiale mortaliteit. De resultaten uit dit onderzoek sluiten aan bij die van Wingard (1982), House (1982), Berkman (1979) en Blazer (1982). Gebrek aan sociale steun of het niet ingebed zijn in een veilig sociaal netwerk verhoogt de gezondheidsrisico's.

In dit onderzoek blijken gescheiden mannen niet van gehuwde mannen te verschillen in hun (cardiale) sterftekans. Weduwnaren bleken echter een drievoudig verhoogde kans te hebben om ten gevolge van een myocard infarct te sterven. Deze bevinding sluit aan bij de in de inleiding genoemde studie van Parker, Rees en Cottington. Aangezien het moment, waarop de weduwnaars hun echtgenote verloren, onbekend is, kan aan de hand van deze data echter niet gezegd worden of dit verhoogde 
risico aan de verlieservaring op zich of aan de afwezigheid van de belangrijkste bron van sociale steun toegeschreven moet worden. Het verband tussen roken en cardiale sterfte bleek in deze studie verre van significant te zijn $(p=.23)$. Zou in de onderhavige analyse van de KRIS data niet alleen de cardiale sterfte maar ook de cardiale morbiditeit betrokken zijn, dan zou wel een significante associatie gerapporteerd zijn. Over de gezondheidseffecten van roken zal in een apart verslag worden ingegaan.

In dit onderzoek kon sociale steun slechts door één variabele geoperationaliseerd worden. Andere onderzoekers registreerden ook de hoeveelheid en de kwaliteit van de persoonlijke en sociale interacties. Deze meer gedetailleerde onderzoekingen zijn nodig om een tweetal vragen te beantwoorden. Hoe belangrijk zijn respectievelijk het aantal, het type, de beschikbaarheid en de voldaanheid over de sociale interacties? De tweede vraag betreft het waarom van het positief verband tussen sociaal isolement en sterftekans. Berust dit op het feit, dat sterke sociale steun een buffer vormt in de stressvolle contacten met de buitenwereld, op een onvoldane behoefte aan sociaal contact of op de verminderde mogelijkheid ook voor het beschermen van gezondheid nuttige dingen van elkaar te leren?

De meeste van deze vragen staan nog open. De bevinding dat het relatieve risico verbonden aan het ongehuwd zijn sterker is dan het relatieve risico van al dan niet roken rechtvaardigt nadere studies.

\section{$2.5 \quad$ ABSTRACT}

This paper describes the association between marital status and mortality using the data obtained in the KRIS follow-up study.

Compared to married males singles were found to be at increased risk for total mortality $(R R=2.77 ; p=<.01)$. When controlling for relevant risk factors by a multiple logistic regression analysis the adjusted risks are 2.61 and 2.80 respectively. No differences in risk for total mortality were found between married men and widowes or divorced men. However, the risk or cardiac mortality was elevated among the widowers $(\mathrm{RR}=3.03 ; \mathrm{p}=.07)$. 


\subsection{LITERATUUR}

Appels A., F. Otten, P. Mulder \& F. Sturmans, De KRIS follow-up study I. Methoden van dataverzameling. T. Soc. Gezondheidsz. 66 (1988) 18-21.

Berkman, L.F. \& S.L. Syme, Social networks, host resistance, and mortality: a nine-year follow up study of Alameda country residents. Amer. J. Epidem. 109 (1979) 186-204.

Blazer, D.G., Social Support and mortality in an eldery community population. Amer. J. Epidem. 104 (1976) 1017-1023.

Cassel, J., The contribution of the social environment to host risistance. Amer. J. Epidem. 104 (1976) 1017-1023.

Cobb, S., Social support as a moderator of life stress. Psychosom. Med. 38 (1976) 300314.

Cottington, E.K., K. Matthews, E. Talbot \& L. Kuller, Environmental events, preceeding sudden death in women. Psychosom. Med. 42 (1980) 567-573.

Glasunov I.S., J.E. Dowd, A. Baubiniene, V. Grabauskas, F. Sturmans \& J.H. Schuurman (eds), The Kaunas Rotterdam Intervention Study. Elsevier/North Holland, Amsterdam 1981.

House J.S., C. Robbins \& H.L. Metzner, The association of social relationships and activities with mortality: prospective evedence from the Tecumseh Community Health Study. Amer. J. Epidem. 116 (1982) 123-140.

Kleinbaum D.G., L.L. Kupper \& H. Morgenstern, Epidemiologic Research. Principles and Quantitative methods. Lifetime learning publications, Belmont, California 1982.

Koskenvuo M., S. Sama \& J. Kaprio, Cause specific mortality by marital status status and social class in Finland during 1969-1871. J. Chron. Dis. 33 (1980) 95-106.

Parkes, C.H., B. Benjamin \& R.G. Fitzgerald, Broken heart: a statistical study of increased mortality among widowers. Brit. Med. J. 1 (1969) 740-743.

Rees, W.D. \& S.G. Lutkins, Mortality of bereavement. Brit. Med. J. 4 (1967) 13-16.

Wingard D.L., The sex differential in mortality rates. Amer. J. Epidem. 115 (1982) 205216. 



\title{
HOOFDSTUK 3 \\ De KRIS follow-up studie III: \\ De effecten van roken op totale mortaliteit, hartinfarct en kanker van de luchtwegen
}

\author{
(F. Otten, J. van Reek, A. Appels, P. Mulder, F. Sturmans)
}

(T. Soc. Gezondheidsz. 1988; 66: 154-156)

In het kader van de Kaunas-Rotterdam Interventie Studie (KRIS) werden in 1972/1973 3365 Rotterdamse mannen van 44-60 jaar onderzocht op cardiovasculaire risicofactoren. Dit cohort werd gedurende $91 / 2$ jaar gevolgd. In dit arikel wordt verslag gedaan van de effecten van verschillende vormen van roken. In vergelijking met nooit-rokers hebben zij, die tien of meer sigaretten per dag roken een hogere kans op totale mortaliteit $(R R=2.06)$, op een hartinfarct $(R R=2.30)$ en op sterfie aan kanker van de luchtwegen $(R R=7.10)$. Dit beeld blijf vrijwel ongewijzigd na controle voor leeftijd en somatische risicofactoren. Bij hen, die korter dan 10 jaar gestopt zijn met roken blijft de sterftekans significant verhoogd. Bij hen, die langer dan 10 jaar gestopt zijn, zijn de gezondheidsrisico's vrijwel gelijk aan die van hen, die nooit gerookt hebben.

\subsection{INLEIDING}

Roken vormt een ernstig risico voor de gezondheid. Vier grote prospectieve onderzoeken van de jaren vijftig naar de invloed van roken op mortaliteit hebben dit eenduidig aangetoond (Haenszel 1966, Cuyler Hammond e.a. 1958, Doll e.a. 1976, Keys 1970). De relevante resultaten van deze studies worden op deze plaats nogmaals vermeld: In vergelijking tot niet-rokers hebben rokers een grotere sterftekans. Dit risico neemt toe naarmate men meer rookt. Hetzelfde resultaat is van toepassing wanneer de sterfte wordt uitgesplitst naar cardiovasculaire sterfte en sterfte ten gevolge van kanker van de luchtwegen. Verder hebben ex-rokers een grotere sterftekans dan nietrokers waarbij het risico afneemt naar het aantal jaren dat met roken is gestopt. Ook hier geldt dat voor cardiovasculaire sterfte en sterfte ten gevolge van kanker dezelfde resultaten werden gevonden.

$\mathrm{Er}$ is weinig reden om eraan te twijfelen dat deze verbanden in Nederland anders zouden liggen dan in het buitenland. Het is echter opvallend dat er nauwelijks prospectieve Nederlandse gegevens over het risico verbonden aan roken bestaan. 
Slechts in het kader van het Zeven Landen Onderzoek is hierop vluchtig ingegaan (Keys 1970). Het blijft belangrijk om de betekenis van deze meest bekende risicofactor exact te documenteren, temeer omdat het percentage pijp- en sigarenrokers in Nederland relatief veel groter is dan in het buitenland. Aan de hand van de gegevens van de KRIS-study deed zich de mogelijkheid voor om op prospectieve wijze het effect van roken op de genoemde eindpunten nader te onderzoeken.

\subsection{METHODEN}

In 1972-1973 werden 3365 Rotterdamse mannen in de leeftijd van 45-59 jaar gescreend in een cardiovasculair WHO-programma, de Kaunas Rotterdam Interventie Studie (KRIS). Het ontwerp van de studie is elders beschreven (Glasunov e.a. 1981). In 1982 werd in het kader van deze KRIS-studie een additioneel onderzoek gehouden, waarbij op retrospectieve wijze werd nagegaan welke ex-deelnemers waren overleden of in de tussentijd een hartinfarct hadden gehad. Er bleken 350 mannen te zijn overleden, waarvan 60 ten gevolge van kanker van de luchtwegen en 69 ten gevolge van een myocard infarct (de mannen met een cardiovasculaire voorgeschiedenis werden hierbij uitgesloten). Wederom met uitsluiting van mannen met een cardiovasculaire voorgeschiedenis bleken gedurende de $91 / 2$ jaar follow-up 94 mannen een waarschijnlijk of zeker niet-fataal myocard infarct te hebben doorgemaakt. Voor een gedetailleerde beschrijving van dit morbiditeits- en mortaliteitsonderzoek wordt verwezen naar Appels e.a. (1988).

Het rookgedrag werd in 1972/73 onderzocht bij de hele onderzoekspopulatie. Wat betreft het 'actuele' rookgedrag werd gevraagd of sigaretten, pijp of sigaren werden gerookt, en naar het aantal gerookte sigaretten per dag. Wat betreft het vroegere rookgedrag werd gevraagd hoeveel jaren geleden men met het roken was gestopt. Op basis van deze informatie werden de deelnemers onderscheiden met betrekking tot hun rookgedrag. Deze indeling omvat de categorieēn 'nooit gerookt', 'meer dan 10 jaar geleden gestopt met roken', 'alleen sigaar en/of pijproker', 'rookt 1-9 sigaretten per dag' en 'rookt 10 of meer sigaretten per dag'. Allereerst worden de ruwe associaties van deze rookvariabele met de eindpunten mortaliteit, infarctincidentie en sterfte ten gevolge van kanker van de luchtwegen berekend. Vervolgens wordt per type eindpunt deze associatie door middel van een logistisch regressiemodel voor relevante confounders en/of effect-modifiers gecorrigeerd. Voor de eindpunten mortaliteit en sterfte ten gevolge van kanker aan het ademhalingsapparaat werden als mogelijke confouders en effect-modifiers leeftijd en burgerlijke staat (al of niet gehuwd) genomen. Voor het eindpunt infarctincidentie werden hieraan nog de Queteletindex, diastolische bloeddruk, plasmacholesterol en glucosetolerantie toegevoegd.

Effect-modifying, waaronder verstaan wordt dat bijvoorbeeld de combinatie van veel roken en hoge bloeddnuk een extra risico met zich meebrengt, werd gedefi- 
nieerd als relevante le-orde interacties tussen de rookvariabele en de controle variabelen per type eindpunt. Met behulp van een likelihoodsratio-test werd nagegaan of het model met alle le-orde interacties adequater was dan het model zonder deze interactie termen. Zo ja, dan moet de relevante $1^{e}$-orde interactie in het model opgenomen worden; zo nee, dan is er geen sprake van effect-modifying en kunnen interactie termen weggelaten worden (Kleinbaum e.a. 1985). De logistische regressie analyses zijn uitgevoerd met de LR-procedure van het BMDP-pakket.

\subsection{RESULTATEN}

Bijna alle onderzochte mannen hadden ervaring met roken. Drie en negentig procent had ooit gerookt. Bij de aanvang van het onderzoek rookte 67 procent van de deelnemers en zei 25 procent gestopt te zijn (tabel 1). De gemiddelde sigarettenconsumptie was 17 stuks per dag per sigarettenroker. De voor onderrapportage gecorrigeerde consumptie per sigarettenroker was landelijk 20 stuks in 1972 (Van Reek 1985). Men mag aannemen dat eenzelfde onderrapportage ook voor het cohort van de KRIS-studie geldt. In tabel 2 zijn voor iedere rookcategorie apart de absolute aantallen weergegeven van het totaal aantal overledenen, de overledenen ten gevolge van kanker aan de luchtwegen en het aantal deelnemers dat tijdens de follow-up periode een al dan niet fataal hartinfarct kreeg.

Uit de tabellen 1 en 2 kan rechtstreeks afgeleid worden dat bijvoorbeeld het percentage hartinfarcten bij de nooit-rokers $7 / 244=3 \%$ bedroeg en bij hen die 10 of meer sigaretten per dag roken $101 / 1719=6 \%$.

Tabel 1 Frequentieverdeling van verschillende vormen van rookgedrag bij de aanvang van de KRIS studie

\begin{tabular}{|l|r|r|}
\hline Categorie & N & . \\
\hline Nooit gerookt & 244 & 07 \\
Meer dan 10 jaar geleden gestopt & 386 & 12 \\
Minder dat 10 jaar geleden gestopt & 452 & 13 \\
Alleen pijp of sigaar & 143 & 04 \\
I-9 sigaretten per dag & 403 & 12 \\
l0 of meer sigaretten per dag & 1719 & 51 \\
geen informatie & 18 & 01 \\
\hline Totaal & 33655 & 100 \\
\hline
\end{tabular}


Tabel 2 Absolute aantallen overledenen, overledenen ten gevolge van kanker van de luchtwegen en al dan niet fatale hartinfarcten

\begin{tabular}{|l|r|r|r|}
\hline & Totsal & $\begin{array}{l}\text { Overleden } \\
\text { kanker }\end{array}$ & hartinfarct \\
\hline Nooit gerookt & 15 & 1 & 7 \\
Meer dan 10 jagr geleden gestopt & 25 & 2 & 15 \\
Minder dan 10 jaar geleden gestopt & 49 & 5 & 20 \\
Alleen pijp of sigas & 10 & 1 & 6 \\
1-9 sigaretten per dag & 44 & 4 & 14 \\
10 of meer sigaretten per dag & 204 & 47 & 101 \\
Geen informatie & 3 & 0 & 0 \\
\hline
\end{tabular}

De ongecorrigeerde resultaten laten zien dat mannen die minder dan 10 jaar geleden zijn gestopt met roken in vergelijking tot nooit-rokers een significant hogere sterftekans hebben. Eveneens hebben mannen die sigaretten roken (1-9 en 10 of meer) een hogere sterftekans dan mannen die nooit roken. De ruwe relatieve risico's zijn respectievelijk $1.86,1.87$ en 2.06 . Ten aanzien van de eindpunten infarctincidentie en sterfte ten gevolge van kanker van de luchtwegen blijken alleen mannen die 10 of meer sigaretten per dag roken een significant hoger risico dan de nooit-rokers te hebben. De ruwe relatieve risico's zijn respectievelijk 2.30 en 7.10. Zij die alleen pijp of sigaren rookten bleken geen hogere kans op kanker, een hartinfarct of totale sterfte te hebben (tabel 3).

Tabel 3 De ruwe relatieve risico's en hun overeenkomstige 95\% betrouwbaarheidsintervallen van diverse vormen van rookgedrag op mortaliteit, hartinfarct en sterfte ten gevolge van kanker van de luchtwegen (referentiegroep: nooil rokers)

\begin{tabular}{|l|l|l|l|}
\hline & $\begin{array}{l}\text { Mortaliteit } \\
\text { RR (95\% BI) }\end{array}$ & $\begin{array}{l}\text { Infarctincidentie } \\
\text { RR (95\% BI) }\end{array}$ & $\begin{array}{l}\text { Kanker } \\
\text { RR (95\% BI) }\end{array}$ \\
\hline $10 \mathrm{jr}$ gestopt & $1.06(0.55-2.05)$ & $1.34(0.53-3.35)$ & $1.27(0.17-9.50)$ \\
$\leq 10 \mathrm{jr}$ gestopt & $1.86(1.02-3.38)$ & $1.63(0.67-3.92)$ & $2.84(0.47-17.23)$ \\
Sigarr/pijp & $1.15(0.50-2.63)$ & $1.42(0.46-4.35)$ & $1.72(0.17-17.62)$ \\
$1-9$ sigaretten & $1.87(1.02-3.44)$ & $1.32(0.52-3.33)$ & $2.55(0.41-16.04)$ \\
$\geq 10$ sigaretten & $2.06(1.19-3.54)$ & $2.30(1.05-5.03)$ & $7.10(1.35-37.41)$ \\
\hline
\end{tabular}

Uit de likehoodratio-testen bleek, dat er geen significante interactie effecten tussen rookgedrag en een van controle-variabelen op een van de drie eindpunten gevonden kon worden. Er bleek met andere woorden geen sprake te zijn van effect-modifying. 
Tabel 4 Het verband tussen roken, leeftijd en burgerlijke staat en de totale mortaliteit zaals berekend met behulp van een logistische regressie

\begin{tabular}{|c|c|c|c|}
\hline Variabelen & Regressiecoēfficient & SE & $\mathbf{p}$ \\
\hline Leeftijd (in jaren) & .12 & .01 & .00 \\
\hline Burgerlijke staat: (ongehuwd-gehuwd) & .61 & .15 & .00 \\
\hline \multicolumn{4}{|l|}{ Roken (referentie: nooit roken) } \\
\hline$>10$ jaar gestopt & .09 & .34 & \\
\hline$\leq 10$ jagr gestopt & .68 & .31 & \\
\hline sigaar en/of pijp & .16 & .43 & .00 \\
\hline $1-9$ sigaretten & .67 & .31 & \\
\hline$\geq 10$ sigaretten & .79 & .28 & \\
\hline Constante & -9.06 & .81 & \\
\hline $\begin{array}{l}\text { Goodness of fit: } \\
\text { HOSMER - LEMESHOW } X^{2}=9.93 \\
\text { BROWN } X^{2}=4.96 \mathrm{df}=2 p=.09\end{array}$ & & & \\
\hline
\end{tabular}

Zoals de tabellen 4, 5 en 6 laten zien is roken na correctie voor leeftijd en burgerlijke staat een determinant van de totale sterfte en na correctie voor leeftijd, diastolische bloeddruk en cholesterol een determinant van het hartinfarct en na correctie voor leeftijd een determinant voor kanker van de luchtwegen.

Tabel 5 Het verband tussen roken, leeftijd, cholesterol en bloeddruk en het hartinfanct zoals berekend $\mathrm{m} . \mathrm{b} . \mathbf{v}$ een logistische regressie

\begin{tabular}{|l|r|r|r|}
\hline Predictoren & Regressiecoéfficient & SE & P \\
\hline Cholesterol (mg/100m plasma) & .012 & .002 & .00 \\
Leeftijd (jaren) & .07 & .02 & .00 \\
Diastolische bloeddruk (mm Hg) & .02 & .01 & .01 \\
Roken (referentie: nooit roker) & & & \\
$>10$ jaar gestopt & .29 & .47 & \\
$\leq 10$ jaar gestopt & .46 & .45 & \\
sigar/pijp & .24 & .58 & .03 \\
$1-9$ sigaretten & .34 & .48 & \\
$\geq 10$ sigaretten & .89 & .41 & \\
Constante & -11.90 & 1.47 & \\
\hline Goodness of fit: & & & \\
HOSMER - LEMESHOW $\mathrm{X}^{2}=7.14, \mathrm{df}=6, \mathrm{p}=.31$ & & \\
BROWN $\mathrm{X}^{2}=2.90 . \mathrm{df}=2, \mathrm{p}=.23$ & & \\
\hline
\end{tabular}


Tabel 6 Het verband tussen roken en leeftijd en kanker van de luchtwegen, zoals berekend met behulp van een logistische regressie

\begin{tabular}{|l|r|r|l|}
\hline Predictoren & Regressiecoefficient & SE & $\mathrm{p}$ \\
\hline Leeftijd (jaren) & .19 & .03 & .00 \\
Roken (referentie: nooit roker) & & & \\
$>10$ jaar gestopt & .30 & 1.23 & \\
S10 jaar gestopt & 1.09 & 1.10 & \\
sigaar/pijp & .58 & 1.42 & .07 \\
$1-9$ sigaretten & .97 & 1.12 & \\
$\geq 10$ sigaretten & 1.99 & 1.01 & \\
Constante & -15.72 & 2.18 & \\
\hline
\end{tabular}

Goodness of fit:

HOSMER - LEMESHOW $X^{2}=2.50, \mathrm{df}=3, \mathrm{p}=.48$

BROWN $X^{2}=1.27, d f=2, p=.53$

De op basis van de logistische regressiecoëfficiënten geschatte relatieve risico's zijn weergegeven in tabel 7. Wanneer de gecontroleerde relatieve risico's van de verschillende vormen van rookgedrag worden vergeleken met de overeenkomstige ruwe relatieve risico's dan blijkt dat de multivariate analyses praktisch dezelfde resultaten hebben opgeleverd. Naast mannen, die minder dan 10 jaar geleden gestopt zijn met roken hebben sigarettenrokers een significant groter sterfterisico dan mannen die nooit gerookt hebben. Verder hebben alleen relatief zware rokers (10 of meer sigaretten per dag) in vergelijking tot de nooit rokers een significant hoger risico op een hartinfarct of kanker van de luchtwegen. De relatie tussen roken en deze eindpunten is praktisch onafhankelijk van de andere gespecificeerde risicofactoren.

Tabel 7 De voor de betreffende confounders gecontroleerde relatieve risico's van de diverse vormen van rookgedrag ten aanzien van mortaliteit, infarctincidentie en sterfte ten gevolge van kanker van de luchtwegen. Referentiecategorie: nooit gerookt

\begin{tabular}{|l|l|l|l|}
\hline Rookcategorieēn & $\begin{array}{l}\text { Mortaliteit } \\
\text { RR (95\% BI) }\end{array}$ & $\begin{array}{l}\text { Infarctincidentie } \\
\text { RR (95\% BI) }\end{array}$ & $\begin{array}{l}\text { Kanker } \\
\text { RR (95\% BI) }\end{array}$ \\
\hline$<10$ jaar gestopt & $1.10(0.56-2.14)$ & $1.33(0.53-3.37)$ & $1.34(0.12-15.04)$ \\
S10 jaar gestopt & $1.98(1.08-3.64)$ & $1.58(0.65-3.85)$ & $2.96(0.34-25.69)$ \\
sigaar/pijp & $1.18(0.51-2.71)$ & $1.26(0.41-3.93)$ & $1.79(0.11-28.88)$ \\
$1-9$ sigaretten & $1.96(1.06-3.62)$ & $1.41(0.55-3.60)$ & $2.64(0.29-23.69)$ \\
$\geq 10$ sigaretten & $2.21(1.27-3.82)$ & $2.44(1.10-5.42)$ & $7.29(1.01-52.96)$ \\
\hline
\end{tabular}




\subsection{DISCUSSIE}

De resultaten van de KRIS-studies corresponderen vrij goed met de vier buitenlandse studies, die in de inleiding genoemd zijn. In deze studies varieer het relatieve risico van van het sigaretten roken op totale mortaliteit tussen 1.6 en 2.2.

Ook de schattingen van het relatieve risico van roken voor het krijgen van een hartinfarct corresponderen met buitenlandse studies. Zo bleek het relatieve risico voor sigaretten roken zowel in het National Cooperative Pooling Project (Pooling Project Research group 1978, Surgeon General 1983) als in een studie onder de bevolking van Kopenhagen (Gyntelberg e.a. 1981) 2.10 te zijn. Voor longkanker werden sterfteratio's variërend van vier tot veertien gevonden (Surgeon General 1982). Dit correspondeert met de sterftekans voor kanker aan de luchtwegen, zoals geobserveerd in de KRISstudie.

In de KRIS-studie bleken zij die alleen pijp of sigaar rookten, een licht verhoogde kans op totale sterfte, mortaliteit of kanker van de luchtwegen te hebben. De schattingen van het relatieve risico verbonden met pijp of sigaar roken corresponderen met die van buitenlandse studies. In deze studies was in tegenstelling tot de KRIS-studie dit risico statistisch wel significant, wat voomamelijk is toe te schrijven aan het veel grotere aantal onderzochten, waardoor ook kleine verschillen significant kunnen worden. Het zou echter onjuist zijn om uit deze gegevens te concluderen dat sigarettenrokers beter kunnen overgaan op het roken van pijp of sigaren. Ook het roken van pijp en sigaren verhoogt het gezondheidsrisico enigermate en bovendien bestaat het risico dat bij de overgang van sigaretten naar pijp en sigaren de gewoonte om te inhaleren gehandhaafd blijft (Cuyler Hammond e.a. 1966). In dit onderzoek hadden pijpen sigarenrokers $79 \%$ meer kans op kanker van de luchtwegen. Statistisch is dit getal niet significant. Wij zijn geneigd dit laatste toe te schrijven aan het geringe aantal onderzochten.

De hoofdconclusie van deze analyses is dat het gezondheidsrisico van roken in Nederland niet afwijkt van dat in andere landen. De enige gevolgtrekking kan zijn dat het voorkomen moet worden dat mensen ooit met roken beginnen. Want ook na het stoppen blijft het risico langdurig verhoogd, al neemt dit risico af naarmate met langer gestopt is met roken om na tien jaar overleven vrijwel afwezig te zijn.

\subsection{ABSTRACT}

This paper reports about the association between smoking behavior patterns and some relevant endpoints as observed in the KRIS follow-up study. Compared to those who never have smoked, those who smoke ten or more cigarettes a day are at increased risk for mortality due to all causes $(R R=2.06)$, myocardial infarction $(R R=2.30)$ and mortality due to cancer of the respiratory system $(R R=7.10)$. Crude 
and adjusted risks are almost the same. The risk for mortality due to all causes is higher among those who stopped smoking less than 10 years ago. The health-risks of those who stopped smoking more than 10 years ago are almost identical to the risks of those who never smoked.

\subsection{LITERATUUR}

Appels, A., F. Otten, F. Sturmans \& P. Mulder, De KRIS follow-up Study I. Methoden van dataverzameling. T. Soc. Gezondheidsz. 66 (1988) 18-21.

Cuyler Hammond, E. \& D. Horn, Smoking and death rates. JAMA 155 (1954) 1316-1328 en JAMA 166 (1958) 1294-1308.

Cuyler Hammond, E., Smoking in relation to death rates of one million men and women. In: W. Haenszel (ed.), Epidemiologic approaches to the study of cancer and other chronic diseases. National Cancer Institute Maryland 1966, pp. 127-204.

Cuyler Hammond, E. \& L. Garfinkel, The influence of health on smoking habits. In: W. Heansze] (ed.) Epidemiologic approaches to the study of cancer and other chronic diseases. National Cancer Institute Maryland 1966, pp. 269-285.

Doll, R. \& R. Peto, Mortality in relation to smoking: 20 years' observations on male British doctors. Br. Med. J. 2 (1976) 1525-1536.

Glasunov, I.S., J.E. Dowd, A. Baubiniene, V. Grabaukas, F. Sturmans \& J.H. Schuurman, The Kaunas Rotterdam Intervention Study. Elsevier, Amsterdam, 1981.

Gyntelberg, F., L. Lauridse, P.B. Bedersen \& K. Schubell, Smoking and risk of myocardial infarction in Copenhagen men aged 40-59 with special reference to cheroot smoking. Lancel 1 (1981) 987-989.

Heanszel, W. (ed.), Epidemiologic approaches to the study of cancer and other chronic diseases. National Cancer Institute Maryland 1966, pp. 1-285.

Kahn, H.A., The Dorn Study of smoking among U.S. Veterans: Report of eight and onehalf year of observation. In: W. Haenszel (ed.), Epidemiologic approaches to the study of cancer and other chronic diseases. National Cancer Institute Maryland 1966, pp. 1-125.

Keys, A. (ed.), Coronary heart disease in seven countries. Circulation 41 (1970) Supplement I, $1-211$. 
Pooling Project Research Group, Relationship of blood pressure, serum cholesterol, smoking habit, relative weight and ECG abnormalities to incidence of major coronary events. J. Chron. Dis. 31 (1978) 201-306.

Reek, J. van, Smoking behaviour in the Netherlands. Hygie 4 (1985) 19-23.

Surgeon General, The health consequences of smoking: cardiovascular disease. USDHHS, Rockville 1983.

Surgeon General, The health consequences of smoking: cancer. USDHHS, Rockville 1982. 


\title{
HOOFDSTUK 4 \\ De KRIS follow-up studie IV: \\ De invloed van alcoholconsumptie op infarctincidentie, cardiale mortaliteit en totale mortaliteit
}

\author{
(F. Otten, A. Appels, P. Mulder, F. Sturmans, J. Schuurman)
}

(T. Soc. Gezondheidsz. 1988; 66: 211-214)

Met behulp van gegevens verkregen in de Kaunas-Rotterdam-Intervention follow-up study (KRIS) werd onderzocht welke relatie er bestaat tussen alcoholconsumptie en het risico op cardiale sterfie, een fataal of non-fataal myocardinfarct en totale mortaliteit. Het cohort van de KRIS-studie bestaat uit 3365 mannen van 45-60 jaar, die gedurende een periode van $91 / 2$ jaar gevolgd werden. Noch in de univariate noch in de multivariate analyses, uitgevoerd met behulp van het Cox regressie model, werd een verband gevonden tussen de mate van alcoholgebruik en genoemde eindpunten. De gegevens bevatten een lichte aanwijzing dat nooit drinkers in vergelijking met hen, die wel alcohol gebruiken een verhoogd risico op een (fataal) infarct en een verhoogde sterftekans hebben.

\subsection{NNLEDING}

In de afgelopen jaren zijn de resultaten van een aantal buitenlandse prospectieve studies over de relatie tussen alcoholgebruik enerzijds en de kans op een hartinfarct of sterfte in het algemeen anderzijds gepubliceerd. Deze studies rapporteren dat drinkers in vergelijking tot niet drinkers een kleiner risico op een hartinfarct of sterfte hebben of dat matige drinkers zowel in vergelijking tot niet drinkers als tot zware drinkers minder risico op een hartinfarct of totale sterfte hebben (een zogenaamd Uvormig verband). Matig drinken zou een beschermend effect op de gezondheid uitoefenen, zodanig dat daardoor de sterftekans en de infarctkans voor een bepaalde follow-up periode verlaagd wordt (Blackwelder e.a. 1980, Marmot e.a. 1981, Gordon e.a. 1984, Friedman e.a. 1986).

In Nederland is tot dusver geen prospectief onderzoek verricht over het effect van alcoholconsumptie op de totale sterftekans en op de kans een hartinfarct te krijgen. Met behulp van de gegevens van de Kaunas-Rotterdam-Intervention-Study (KRIS) is het mogelijk om voor een follow-up periode van $91 / 2$ jaar de mogelijke associatie 
tussen alcoholgebruik en de eindpunten infarct, cardiale mortaliteit en totale sterfte te onderzoeken.

\subsection{METHODEN}

Gedurende de periode 1972-1974 werden 3365 Rotterdamse mannen van 45-60 jaar in het kader van de Kaunas-Rotterdam-Intervention-Studie (KRIS) gescreend op cardiovasculaire risicofactoren. Dit cohort werd gedurende een periode van $91 / 2$ jaar gevolgd. Tijdens deze follow-up periode zijn 350 deelnemers overleden, waarvan 69 aan een hartinfarct, en hadden 94 deelnemers een niet-fataal hartinfarct doorgemaakt. De details van het screeningsonderzoek en van de follow-up studie zijn elders uitvoerig beschreven (Glasunov 1982, Appels 1988). Met behulp van interviewers die de participanten begeleidden bij de invulling van gestandaardiseerde vragenlijsten werd gedurende de screening de nodige informatie omtrent het alcoholgebruik ingewonnen. Op basis van deze gegevens werd door Reelick en Schuurman (1982) een alcoholconsumptievariabele geconstrueerd, die een indicatie geeft van zowel de drinkfrequentie als de per drinkgelegenheid genuttigde hoeveelheid drank. De oorspronkelijke vragen met betrekking tot het alcoholgebruik worden in appendix 1 weergegeven. Op deze plaats wordt met behulp van frequenties en kruistabellen van enkele van de oorspronkelijke alcoholitems de totstandkoming van de uiteindelijke alcoholconsumptievariabele nader toegelicht. In tabel 1 wordt allereerst de frequentieverdeling gepresenteerd van het aantal malen dat men alcohol gebruikte.

Tabel 1 Frequentieverdeling alcoholgebruik

\begin{tabular}{|l|r|r|}
\hline Categorie & $\mathrm{N}$ & $\%$ \\
\hline Nooit gedronken & 291 & 9 \\
Voormalige drinker & 92 & 3 \\
Enkele keren per jasr & 212 & 6 \\
Een enkele keer per mand & 381 & 11 \\
Eén keer per week & 478 & 14 \\
Enige keren per week maar niet dagelijks & 622 & 18 \\
Dagelijks & 1271 & 38 \\
Geen informatie & 18 & 1 \\
\hline Total & 3365 & 100 \\
\hline
\end{tabular}

Ongeveer $38 \%$ van de respondenten behoorde tot de dagelijkse drinkers. Dit percentage komt overeen met het percentage dat 5 jaar later in een landelijk onderzoek werden gevonden door de Stichting voor Wetenschappelijk Onderzoek van Alcohol en Druggebruik voor mannen van 40 jaar en ouder (Sijlbing 1978). In dat onderzoek dronk $35 \%$ van 160 ondervraagden uit deze leeftijdsgroepen dagelijks. In tabel 2 wordt 
de drankvoorkeur getoond van degenen die dagelijks dronken en zij die niet dagelijks dronken.

Tabel 2 Voorkeur voor soort alcoholische drank van dagelijkse en niet dagelijkse drinkers

\begin{tabular}{|c|c|c|c|c|c|c|}
\hline \multirow[t]{2}{*}{ Dranksoort } & \multicolumn{2}{|c|}{ Niet dagelijks } & \multicolumn{2}{|c|}{ Dagelijks } & \multicolumn{2}{|c|}{ Totaal } \\
\hline & $\mathbf{N}$ & $\%$ & $\mathbf{N}$ & \% & $\mathbf{N}$ & $\%$ \\
\hline Alleen bier & 306 & 18 & 157 & 12 & 463 & 14 \\
\hline Alleen wijn & 123 & 7 & 55 & 4 & 178 & 5 \\
\hline Alleen sterke drank & 436 & 26 & 340 & 27 & 776 & 23 \\
\hline Bier/wijn & 81 & 5 & 36 & 3 & 117 & 4 \\
\hline Bier/sterke drank & 406 & 24 & 348 & 27 & 754 & 22 \\
\hline Wijn/sterke drank & 117 & 7 & 97 & 8 & 214 & 6 \\
\hline Bier/wijn/sterke drank & 205 & 12 & 227 & 18 & 432 & 13 \\
\hline Geen opgave dranksoort & 19 & 1 & 11 & 1 & 30 & 1 \\
\hline Nooit drinkers + vroegere driakers & - & - & - & - & 383 & 12 \\
\hline Geen infornuatie & - & - & - & - & 18 & 0 \\
\hline Totaal & 1693 & 100 & 1271 & 100 & 3365 & 100 \\
\hline
\end{tabular}

Bij statistische toetsing (onder weglating van respectievelijk de categorieën: geen opgave dranksoort, niet drinker, geen informatie) bleek er een significant verschil te zijn tussen de dagelijkse en niet dagelijkse drinkers met betrekking tot de soort alcoholhoudende drank waaraan zij de voorkeur gaven $\left(X^{2}=53\right.$, df=6, $\left.p=.00\right)$. In vergelijking tot de dagelijkse drinkers beperken de niet-dagelijkse drinkers zich vaker tot uitsluitend bier of wijn. Bij het screeningsonderzoek is ook gevraagd naar de hoeveelheden die men per drinkgelegenheid tot zich nam. In tabel 3 worden de hoeveelheden vermeld voor achtereenvolgens bierdrinkers, wijndrinkers en drinkers van sterke drank telkens uitgesplitst naar diegenen die iedere dag dronken en diegenen die niet iedere dag dronken.

Op basis van de hierboven besproken gegevens omtrent repectievelijk de drinkfrequentie, het soort en de hoeveelheden genuttigde drank per drinkgelegenheid werd de in tabel 4 weergegeven ordinale alcoholconsumptie variabele samengesteld.

Ter verduidelijking van de categorieën: iemand die nooit gedronken heeft is een KRIS-participant die ten tijde van de screening aangaf dat hij nooit alcohol heeft genuttigd; een voormalige drinker is iemand die ten tijde van de screening niet meer dronk maar in het verleden wel gedronken heeft; een incidentele drinker is iemand die enkele keren per jaar of een enkele keer per maand dronk; een regelmatige drinker is iemand die een keer of enige keren per week dronk, maar niet dagelijks. 
Tabel 3 De hoeveelheden bier, wijn en sterke drank per drinkgelegenheid voor dagelijkse en niet dagelijkse drinkers

\begin{tabular}{|l|c|r|r|r|r|r|}
\hline \multirow{2}{*}{ Hoeverlheid } & \multicolumn{2}{|c|}{ Niet dagelijks } & \multicolumn{2}{c|}{ Dagelijks } & \multicolumn{2}{c|}{ Totaal } \\
\cline { 2 - 7 } & $\mathrm{N}$ & $\%$ & $\mathrm{~N}$ & $\%$ & $\mathrm{~N}$ & $\%$ \\
\hline Bier & & & & & & \\
$1-5$ glazen & 817 & 82 & 602 & 83 & 1415 & 82 \\
$>5$ glazen & 184 & 18 & 120 & 17 & 304 & 18 \\
Total & 1001 & 100 & 722 & 100 & 1723 & 100 \\
Wija & 522 & 97 & 389 & 92 & 911 & 95 \\
$1-4$ glazen & 16 & 3 & 33 & 8 & 49 & 5 \\
$>4$ glazen & 538 & 100 & 422 & 100 & 960 & 100 \\
Totaal & 1024 & 87 & 872 & 85 & 1896 & 86 \\
Sterke drank & 149 & 13 & 149 & 15 & 298 & 14 \\
1-3 glazen & 1173 & 100 & 1021 & 100 & 2194 & 100 \\
$>3$ glazen & & & & & & \\
\hline Totagl & & & & & & \\
\hline
\end{tabular}

Tabel 4 Frequentieverdeling van de alcoholconsumptie zoals vastgesteld bij de screening

\begin{tabular}{|c|c|c|}
\hline Alcoholconsumptie & $\mathbf{N}$ & $\%$ \\
\hline Nooit alcobol gedronken & 291 & 9 \\
\hline Voormalige drinkers & 92 & 3 \\
\hline Incidentele drinker ( $\max 1 \times$ per maand een alcoholhoudende drank) & 593 & 17 \\
\hline $\begin{array}{l}\text { Regelmatige drinkers van kleine hoeveelheden ( } 1 \mathrm{t} / \mathrm{m} 5 \text { glazen bier of } 1 \mathrm{t} / \mathrm{m} 4 \mathrm{gla}- \\
\text { zen wijn of } 1 \mathrm{t} / \mathrm{m} 3 \text { glazen sterke drank)(regelmatig is minimaal } 1 \mathrm{x} \text { per week of } \\
\text { vaker maar niet dagelijks) }\end{array}$ & 866 & 26 \\
\hline Dagelijkse dninkers van kleine hoeveelheden (id. bovenstande) & 978 & 29 \\
\hline $\begin{array}{l}\text { Regelmatige dringers van grote boeveelbeden (moer dan } 5 \text { glazen bier of } 4 \text { glazen } \\
\text { wijn of } 3 \text { glazen sterke drank) }\end{array}$ & 232 & 7 \\
\hline Dagelijkse drinkers van grote boeveelheden (id. bovenstande) & 285 & 8 \\
\hline Geen informatie (niet in te delen) & 28 & 1 \\
\hline Totanl & 3365 & 100 \\
\hline
\end{tabular}

Het nuttigen van kleine hoeveelheden alcoholhoudende drank is het drinken van $1 \mathrm{t} / \mathrm{m} 5$ glazen bier, $1 \mathrm{t} / \mathrm{m} 4$ glazen wijn of $1 \mathrm{t} / \mathrm{m} 3$ glazen sterke drank per drinkgelegenheid. Het nuttigen van grote hoeveelheden is het drinken van meer dan 5 glazen bier, meer dan 4 glazen wijn of het drinken van meer dan 3 glazen sterke drank per drinkgelegenheid

In deze constructie van de categorieën van alcoholconsumptie kan een onzuiverheid zitten. Van degenen die meerdere soorten alcoholhoudende dranken gebruikten, is niet duidelijk of ze per drinkgelegenheid verschillende soorten door elkaar dronken of zich op én drinkgelegenheid tot én soort beperkten, maar die soort per drinkgelegenheid varieerden. Indien veel mensen, die aangaven meerdere soorten drank te 
gebruiken dit op één drinkgelegenheid hebben gedaan bestaat de mogelijkheid van onderschatting van de zwaarste groep drinkers (de categorieën 6 en 7 van tabel 4). Als iemand bijvoorbeeld zegt bier, wijn en sterke drank te drinken en op één avond gewoonlijk 3 bier, 3 glazen wijn en 3 glazen jenever drinkt wordt hij toch tot de matige drinkers gerekend, omdat de hoeveelheid die hij nuttigt bij geen der afzonderlijke dranksoorten de grens voor zwaar drinken overschrijdt. De kans dat hierdoor het percentage matige drinkers (de categorieën 4 en 5 van tabel 4) wordt overschat, lijkt echter niet groot.

Met behulp van het Cox regressiemodel werden allereerst de 'ruwe' en vervolgens de voor relevante confounders en/of effectmodifiers gecorrigeerde effecten van alcoholconsumptie ten aanzien van de eindpunten totale mortaliteit, cardiale mortaliteit en infarctincidentie (fataal of niet-fataal hartinfarct) bepaald. In de Cox regressie-analyse werden de nooit-drinkers als referentie categorie genomen zodat de alcoholconsumptie gerepresenteerd wordt door zes onderling afhankelijke dummy-variabelen, die tezamen de variabele alcoholconsumptie representeren. Aangezien deze dummy's tezamen de alcoholvariabele uitdrukken dienen zij ook steeds als een geheel in de statistische toetsingsprocedure betrokken te worden. Voor deze analyse werd gekozen omdat deze zowel de tijd tussen screening en het bereiken van het eindpunt in de berekening betrekt als de contrasten tussen de referentiegroep en iedere categorie afzonderlijk uitdrukt. Dit laatste is belangrijk omdat hierdoor een eventueel U-vormig verband zichtbaar wordt. Als mogelijke confounders en effect-modifiers werden voor het eindpunt totale mortaliteit de leeftijd (in jaren), het rookgedrag (al dan niet roken) en de burgerlijke staat (al dan niet gehuwd) genomen. Bij de eindpunten infarctincidentie en cardiale mortaliteit werden hieraan nog de cardiovasculaire risicofactoren Queteletindex $\left(\mathrm{kg} / \mathrm{m}^{2}\right)$, diastolische bloeddruk $(\mathrm{mmHg})$ en plasmacholestorolgehalte $(\mathrm{mg} / 100 \mathrm{ml})$ aan toegevoegd. Bij de analyses op infarctincidentie en cardiale mortaliteit werd alleen uitgegaan van mannen die ten tijde van de screening géén cardiovasculaire voorgeschiedenis hadden.

Effect-modifying werd gedefinieerd als relevante le-orde interacties tussen de alcoholvariabele en één of meer van de gespecificeerde controlevariabele per type eindpunt. Met behulp van een likelihoodratio-test werd nagegaan of het model met alle le-orde interacties adequater was dan het model zonder deze interactietermen. Zo ja, dat moeten de relevante le-orde interacties met een stapsgewijze procedure opgespoord worden; zo nee, dan kunnen de interactietermen weggelaten worden en is er geen sprake van effect-modifying (Kleinbaum e.a. 1985). De analyses zijn uitgevoerd met de 2L-procedure van het BMDP-pakket (Dixon e.a. 1985) 


\subsection{RESULTATEN}

In tabel 5 is voor iedere categorie alcoholgebruikers weergegeven hoeveel procent tijdens de follow-up overleden is, hoeveel procent een fataal hartinfarct kreeg en hoe groot het percentage is van hen die een al dan niet fataal infarct doormaakten.

Tabel 5 Percentages overiedenen, fatale infarcten en fataal of niet fataal infarct per alcoholcategorie

\begin{tabular}{|l|c|c|c|}
\hline & Overleden & Overleden aan hartinfarct & Fataal of niet fataal infarct \\
\hline Niet drinker & 15 & 7 & 10 \\
Voormalig drinker & 12 & 0 & 7 \\
Incidentele drinker & 8 & 2 & 5 \\
Regelmatig weinig & 10 & 4 & 8 \\
Dagelijks weinig & 10 & 3 & 6 \\
Regelmatig veel & 10 & 3 & 5 \\
Dagelijks veel & 12 & 3 & 6 \\
\hline
\end{tabular}

Omdat vanwege de uitsluitingscriteria de absolute aantallen per categorie verschillen zijn deze terwille van de overzichtelijkheid niet weergegeven.

Tabel 5 laat zien dat voor ieder van de drie eindpunten het hoogste percentage gevonden wordt bij hen die nooit gedronken hebben, terwijl er geen opvallende verschillen zijn tussen de andere categorieën. Met behulp van chi-kwadraat toetsen werd nagegaan of de geobserveerde aantallen afweken van de aantallen, die op grond van de randmarginalen te verwachten zijn. Dit bleek voor geen van de drie eindpunten het geval te zijn. Dit betekent dat er geen samenhang gevonden werd tussen alcoholconsumptie en een van deze eindpunten.

Tabel 5 laat tevens zien dat niemand uit de categorie voormalige drinkers aan een hartinfarct overleden was. Dit maakt het onmogelijk een mathematische oplossing voor de Cox regressie te berekenen. Daarom werd de groep voormalige drinkers uitgesloten van verdere cardiale mortaliteitsanalyses.

Uit de likelihood-testen bleek dat er geen significante interactie effecten tussen alcoholconsumpte en een van de controle-variabelen op een van de drie eindpunten gevonden kon worden. Dit betekend dat er, althans in dit materiaal, geen modificerende mechanismen (bijvoorbeeld: alcohol verhoogt het risico op een fataal hartinfarct bij hen, die een hoge bloeddruk hebben) werkzaam zijn.

De voor de mogelijke confounders gecorrigeerde associatie tussen alcoholconsumptie en de drie eindpunten, zoals verkregen in de Cox regressie analyse, zijn weergegeven in de tabellen 6 tot en met 8 . Zij laten zien dat, op én uitzondering na alle rate ratio's kleiner dan 1.00 zijn. Ook in de multivariate analyses blijkt dat alle categorieën drinkers een lager risico hebben dan de nooit-drinkers. Bij een significantieniveau van .05 en tweezijdige toetsing blijkt dat de door dummy-vergelijkingen gepresenteerde 
alcoholconsumptie geen statisch significante predictieve waarde heeft voor een van de drie eindpunten.

Tabel 6 Het voor leeftijd, burgerlijke staat en roken gecorrigeerde relatieve risico van alcoholconsumptie op de totale mortaliteit (referentiegroep: nooit drinkers)

\begin{tabular}{|l|l|l|}
\hline & RR & $95 \%$ B.I. \\
\hline Voormalig drinker & .74 & $.38-1.44$ \\
lncidentele drinker & .61 & $.40-.91$ \\
Regelmatig weinig & .69 & $.48-.99$ \\
Dagelijks weinig & .71 & $.50-1.02$ \\
Regelmatig veel & .62 & $.37-1.04$ \\
Dagelijks veel & .87 & $.55-1.38$ \\
\hline $\mathrm{x}^{2}=7.51 ; \mathrm{df}=6 ; \mathrm{p}=.28$ & & \\
\hline
\end{tabular}

Tabel 7 Het voor leeftijd, burgerlijke staat, Queteletindex, diastolische bloeddruk, cholesterol en roken gecorrigeerde relatieve risico van alcoholconsumptie op de cardiale mortaliteit (Referentiegroep: nooit-drinkers)

\begin{tabular}{|l|c|c|}
\hline & $\mathrm{RR}$ & $95 \%$ B.I. \\
\hline Incidentele drinker & .58 & $.21-1.62$ \\
Regelmatig weinig & 1.05 & $.45-2.47$ \\
Dagelijks weinig & .86 & $.36-2.04$ \\
Regelmatig veel & .61 & $.18-2.10$ \\
Dagelijks veel & .67 & $.21-2.12$ \\
\hline $\mathrm{x}^{2}=3.02 ; \mathrm{df}=5 ; \mathrm{p}=.70$ & & \\
\hline
\end{tabular}

Tabel 8 Het voor leeftijd, burgerlijke staat, Queteletindex, diastolische bloeddruk, cholesterol en roken gecorrigeerde relatieve risico van alcoholconsumptie op een fataal of niet-fataal infarct (referentiegroep: nooit drinkers)

\begin{tabular}{|l|l|l|}
\hline & RR & $95 \%$ B.I. \\
\hline Voormalig drinker & .65 & $.22-1.90$ \\
lncidentele drinker & .54 & $.30-.99$ \\
Regelmatig weinig & .80 & $.48-1.35$ \\
Dagelijks weinig & .55 & $.33-.95$ \\
Regelmatig veel & .45 & $.20-1.01$ \\
Dagelijks veel & .55 & $.26-1.12$ \\
\hline $\mathrm{x}^{2}=8.89 ; \mathrm{df}=6 ; \mathrm{p}=.18$ & & \\
\hline
\end{tabular}




\subsection{DISCUSSIE}

De belangrijkste conclusie, die uit bovenstaande gegevens getrokken kan worden is dat in het databestand van de KRIS follow-up studie geen statistisch significant verband tussen alcoholconsumptie en totale sterfie, het fataal-infarct en de totale infarctincidentie gevonden kan worden.

Wel geeft de bevinding dat alle categorieën drinkers een kleiner risico op een van de eindpunten hebben dan nooit-drinkers aan dat nooit-drinkers een iets groter risico lopen dan zij die wel alcohol gebruiken. Zou de steekproefomvang groter geweest zijn, dan zou waarschijnlijk wel een statistisch significant negatief verband gevonden zijn. Wanneer men aposteriori de niet-drinkers met alle drinkers vergelijkt is dit verband voor alle eindpunten statistisch wel significant.

De KRIS-studie kon het door Marmot e.a. (1981) geconstateerde U-vormige verband tussen drinken en sterfte niet repliceren. De data suggereren wel dat van matig drinken een gezondheidsbeschermende werking uit zou gaan. Dat dit laatste inderdaad het geval is kan men echter niet uit dit onderzoek concluderen. Nooit-drinkers kunnen zich in meerdere opzichten van drinkers onderscheiden en het zou kunnen zijn dat een medische, psychologische of sociale karakteristiek aan de geconstateerde verschillen ten grondslag ligt. Het databestand van de KRIS-study laat niet toe hier nadere uitspraken over te doen.

Voorzichtigheid bij het formuleren van conclusies is ook geboden omdat er onvoldoende gegevens beschikbaar zijn over de validiteit en de betrouwbaarheid van de indeling in verschillende groepen van alcoholconsumptie. Het is niet alleen moeilijk om precies te schatten hoeveel men drinkt, maar ook als men dit wel weet kan men geneigd zijn de gemiddelde consumptie wat lager voor te stellen dan zij in werkelijkheid is (Garretsen 1983). Dit type non-differentiële misclassificatie leidt per definitie tot een onderschatting van de effectparameters van de exposurevariabele (Rothman 1986). Als deze vorm van 'information-bias' daadwerkelijk van toepassing is op de hier geconstrueerde alcoholconsumptievariabele dan betekent dit dat de gecorrigeerde rate ratios zoals die in de tabellen $6 \mathrm{t} / \mathrm{m} 8$ worden gepresenteerd eigenlijk kleiner zijn (behoudens die ene uitzondering van tabel 7), met andere woorden het sterfte- en infarctrisico van hen die nooit dronken in vergelijking tot de drinkers zou dan in werkelijkheid nog groter zijn.

Van alle overledenen waren twee personen overleden aan een levercirrose en drie ten gevolge van een verkeersongeval. Deze aantallen zijn te klein voor enige berekening. 


\subsection{ABSTRACT}

This paper examines the possible association between alcoholconsumption and the incidence of coronary heart disease, cardiac mortality and total mortality in a sample of 3365 males, aged 45-60, who were followed during an avarage period of $91 / 2$ years (Kaunas-Rotterdam-Intervention-Study). Analyses were performed by Cox' regression analysis. No associations were observed between alcohol consumption and the specified endpoints. The data may suggest that those who never drink are at increased risk for myocardial infarction and total mortality.

\subsection{LITERATUUR}

Appels, A., F. Otten, P.Mulder \& F. Sturmans, De KRIS follow-up studie I: Methode van dataverzameling. T. Soc. Gezondheidszorg. 66 (1988) 18-21.

Blackwelder, W.C., K. Jano, G.G. Rhoads e.a., Alcohol and mortality: The Honolulu Heart Study. Am. J. Med. 68 (1980) 164-169.

Dixon, W.J. (ed), BMDP Statistical Software. University of California Press, Los Angeles 1985.

Friedman, L.A. \& A.W. Kimball, Coronary heart disease mortality and alcohol-consumption in Framingham. Am. J. Epidemiol. 124 (1986) 481-489.

Garretsen, H.F.L., Probleemdrinken; prevalentiebepaling, beinvloedende factoren en preventiemogelijkheden. Swets en Zeitlinger, Lisse 1983.

Glasunov, I.S., J.E. Dowd, A. Baubiniene, V. Grabauskas, F. Sturmans \& J.H. Schuurman (eds), The Kaunas Rotterdam Intervention Study. Elsevier/North Holland, Amsterdam 1981.

Gordon, T. \& W.B. Kannel, Drinking habits and cardiovascular disease: The Framingham Study. Am. Heart J. 105 (1983) 667-673.

Gordon, T. \& W.B. Kannel, Drinking and mortality: The Framingham Study. Am. J. Epidemiol. 120 (1984) 90-107.

Kleinbaum, D.G., L.L. Kupper \& H. Morgernstem, Epidemiologic research: principles and quantitative methods. Lifetime Learning Publications, Belmont/California 1982. 
Marmot, M.G., G. Rose, M.J. Skipley e.a., Alcohol and mortality: a U-shaped curve. Lancet 1 (1981) 580-583.

Reelick, N.F. \& J.H. Schuurman, Het Kris-project 1972-1978. Rapport No. 36, afd. GVO, GGD Rotterdam 1982.

Rothman, K., Modern Epidemiology. Little, Brown and Company, Boston/Toronto 1986.

Sijlbing, G., Drink- en rookgewoonten. Landelijk onderzoek naar de drink- en rookgewoonten van de Nederlandse bevolking. SWOAD, Amsterdam 1978. 


\section{APPENDIX Interview over alcoholconsumptie}

Bij elke vraag slechts én maal aankruisen s.v.p.

Alcoholgebruik

1a. Gebruikt U alcoholische dranken?

Neen, nooit*

Nu niet, vroeger wel (een jaar of langer geleden)*

Ja, nu en dan

Ja regelmatig

* Enq.: beëindig alcoholinterview

1b. Hoe vaak gebruikt $U$ alcohol

Enkele keren per jaar

Een enkele keer per maand

Eén keer per week

Enige keren per week maar niet dagelijks

Dagelijks

2a. Wat drinkt U gewoonlijk?

Alleen bier

Alleen wijn

Alleen sterke drank

Bier/wijn

Bier/sterke drank

Wijn/sterke drank

Bier/wijn/sterke drank

2b. Hoeveel drinkt U gewoonlijk: ... per keer?

Bier Geen bier

Minder dan 1 liter

Meer dan 1 liter

Wijn (rode en witte wijn, sherry, vermouth, enz)

Geen wijn

Minder dan $1 / 2$ liter

$1 / 2$ liter tot 1 liter

Meer dan I liter

Sterke drank (wiskey, jenever, wodka, cognac, likeur)

Geen sterke drank

1-3 glazen

Meer dan 3 glazen $(1$ glas $=30 \mathrm{cc}$ ) 
Enq: Vraag 2c. alleen stellen aan diegenen, die dagelijks antwoorden op vraag $1 \mathrm{~b}$.

2c. Hoeveel drinkt U gewoonlijk van:... per dag?

Bier Geen bier

Minder dan 1 liter

Meer dan 1 liter

Wijn (rode en witte wijn, sherry, vermouth, enz.)

Geen wijn

Minder dan $1 / 2$ liter

$1 / 2$ liter tot 1 liter

Meer dan 1 liter

Sterke drank (whiskey, jenever, wodka, cognac, likeur)

Geen sterke drank

1-3 glazen

Meer dan 3 glazen 


\title{
HOOFDSTUK 5 De KRIS follow-up studie VI: Stress en cardiale mortaliteit
}

\author{
(A. Appels, F. Otten, P. Mulder, F. Sturmans, J. Schuurmans)
}

(T. Soc. Gezondheidsz. 1989; 67: 308-310)

In het kader van de Kaunas-Rotterdam Interventie Study (KRIS) werden in 1972/1973 3365 Rotterdamse mannen van 45-60 jaar onderzocht op cardiovasculaire risicofactoren. Dit cohort werd gedurende 9 1/2 jaar gevolgd. In dit artikel wordt verslag gedaan over het predictief vermogen van de Reeder stress scale. Stress, zoals gemeten door deze oude schaal bleek de kans op totale mortaliteit, cardiale mortaliteit of cardiale morbiditeit niet te verhogen. De schaal is te heterogeen samengesteld. Zij bevat een item, dat verwijst naar het begrip 'vitale uitputting', $n l$. 'aan het eind van de dag ben ik lichamelijk en geestelijk volledig uitgeput'. Zij die zeiden, dat dit item hen zeer goed beschreef hadden een sterk verhoogd risico op cardiale sterfle in het begin van de follow-up periode. De Hazard Ratio's bedroegen voor de eerste 10,20,30 en 40 maanden follow-up respectievelijk 8.96, 6.33, 4.77 en 3.16. Alhoewel dit een aposteriori analyse is bevestigen deze data het mogelijk belang van uitputtingsgevoelens als prodromale factor.

\subsection{INLEIDING}

De vraag of 'stress' gerekend moet worden tot de cardiovasculaire risicofactoren wordt vaak gesteld. $\mathrm{Zij}$ is echter niet te beantwoorden. Stress is geen begrip met een wetenschappelijke gebruikswaarde. Het woord geeft eerder een onderzoeksgebied aan, waarin aandacht wordt besteed aan uiteenlopende vragen zoals: verhogen bepaalde gedragspatronen, belastende gebeurtenissen of gebrek aan sociale steun de kans op ziekte of psychisch lijden.

In 1970 toen aan de selectie van de onafhankelijke variabelen en de meetinstrumenten voor de Kaunas-Rotterdam Interventie Study (KRIS) gewerkt werd, was de theorie over stress als risicofactor van het hartinfarct nog nauwelijks ontwikkeld. Begrippen als 'social support', 'decision latitude', 'loss of control', 'vitale uitputting' en 'coping' waren nog niet of nauwelijks ontwikkeld. Het enige beschikbare instrument was de Reeder stress scale (Reeder 1969). Doch ook over dit instrument bestond nau- 
welijks informatie. Wellicht mede door het voortijdig overlijden van de ontwerper van deze test is het instrument later in de vergetelheid geraakt.

Omdat prospectieve gegevens kostbaar zijn werd ondanks twijfel aan kwaliteiten van de schaal nagegaan of zij enig voorspellend vermogen had met betrekking tot de eindpunten totale mortaliteit, cardiale mortaliteit en cardiale morbiditeit.

De schaal bevat ook enkele items, die nadere aandacht verdienen, omdat zij verwantschap hebben met begrippen die in later onderzoek cardiovasculaire relevantie bleken te hebben. Dit geldt m.n. voor de vraag: 'Aan het einde van de dag ben ik lichamelijk en geestelijk volledig uitgeput'. Dit item verwijst naar het concept 'vitale uitputting'. Uit cardiologisch-epidemiologisch onderzoek is reeds lang gebleken dat 'ongewone vermoeidheid' tot de prodromen van het hartinfarct en plotselinge dood behoort. De schattingen over de prevalentie van 'gebrek aan energie' of 'ongewone vermoeidheid' onder hen, die in de nabije toekomst aan een hartinfarct overlijden, variëren tussen 40 en $65 \%$. Daarmee is de klacht het meest genoemde prodroom van de plotselinge dood (Kilen 1973, Alonzo 1975, Kuller 1978, Risannen 1978, Fraser 1978). Bij psychologische analyse van deze gevoelens blijkt dat deze het best te typeren zijn als een syndroom van vitale uitputting. Hieronder wordt een toestand verstaan, die bestaat wanneer een persoon niet alleen klaagt over ongewone vermoeidheid en gebrek aan energie maar ook over het gevoel verslagen of gedemoraliseerd te zijn. Prospectief onderzoek heeft inmiddels aangetoond dat deze toestand de kans op een hartinfarct binnen vier jaar meer dan verdubbelt (Appels e.a. 1987). Hetzelfde onderzoek heeft laten zien dat deze toestand vooral een voorspellend vermogen heeft op korte termijn (Appels e.a. 1988). Gezien de nog schaarse empirische gegevens die over het concept 'vitale uitputting' bestaan, blijft het de moeite waard om na te gaan of ook de KRIS-data een aanwijzing bieden dat dit concept cardiovasculaire betekenis kan hebben. Daarom werd niet alleen de Reeder stress schaal maar ook ieder item onderzocht op zijn predictief vermogen.

\subsection{METHODEN}

Gedurende de periode 1972-1974 werden 3365 Rotterdamse mannen van 45-60 jaar in het kader van de KRIS-studie gescreend op cardiovasculaire risicofactoren. Dit cohor werd gedurende een periode van 9 1/2 jaar gevolgd. Tijdens deze follow-up periode zijn 350 deelnemers overleden. Onder hen, die bij de aanvang van het onderzoek geen of een bestaand hartlijden hadden, overleden tijdens deze periode 69 mannen aan een hartinfarct en maakten 94 deelnemers een niet-fataal infarct door. De details van het screeningsonderzoek en van de follow-up studie zijn elders uitvoerig beschreven (Glasunov e.a. 1982, Appels e.a. 1988). Tijdens het screeningsonderzoek werden alle deelnemers uitgenodigd ook de vragen van de Reeder stress scale te beantwoorden. Dit is door 3241 deelnemers (96\%) gebeurd. 
De Reeder stress schaal bestaat uit zeven vragen, met ieder vier antwoordcategorieën: 'dit beschrijft mij heel goed, tamelijk goed, niet zo goed, helemaal niet'. De vragen zijn weergegeven in tabel 1 .

Tabel 1 Vragen van de Reeder Stress Scale en de procentuele verdeling per antwoordcategorie

\begin{tabular}{|c|c|c|c|c|c|}
\hline & \multicolumn{5}{|c|}{ Dit beschrijft mij } \\
\hline & $\begin{array}{l}\text { zeer } \\
\text { goed }\end{array}$ & tam. & $\begin{array}{l}\text { niet zo } \\
\text { goed }\end{array}$ & $\begin{array}{l}\text { bele- } \\
\text { mas } \\
\text { niet }\end{array}$ & $\begin{array}{l}\text { Fac- } \\
\text { torla } \\
\text { ding }\end{array}$ \\
\hline 1. Ik ben vaak gespannen en zenuwachtig & 17 & 36 & 28 & 19 & .58 \\
\hline 2. Ik zit vaak over mijn werk te piekeren & 12 & 26 & 23 & 39 & .62 \\
\hline 3. Mijn dagelijkse werk is zenuwslopend & 12 & 31 & 26 & 31 & .72 \\
\hline 4. Er zjjn vaak spanningen bij mij thuis & 6 & 13 & 25 & 56 & .35 \\
\hline 5. In mijn dagelijkse werk sta ik vaak onder druk & 14 & 30 & 22 & 34 & .71 \\
\hline $\begin{array}{l}\text { 6. Ik ondervind vaak spanningen tussen mij en } \\
\text { andere mensen }\end{array}$ & 7 & 16 & 31 & 46 & .56 \\
\hline $\begin{array}{l}\text { 7. Aan bet eind van de dag ben ik lichamelijk en } \\
\text { geestelijk volledig uitgeput }\end{array}$ & 7 & 22 & 32 & 39 & .58 \\
\hline
\end{tabular}

Omdat weinig bekend is over de psychometrische eigenschappen van de Reeder stress schaal werd een factoranalyse uitgevoerd en werd voor iedere deelnemer een factorscore berekend. Alle deelnemers werden ingedeeld in een van de kwartielen van deze 'stress score'. Met behulp van Cox regressie analyse werd getoetst of deze vier groepen zonder of met correctie voor relevante covariabelen verschilden in hun kans op totale mortaliteit, cardiale mortaliteit en cardiale morbiditeit. Bij de mortaliteitsanalyses werden alle deelnemers betrokken. Deelnemers met een cardiale voorgeschiedenis en zij die aan een niet cardiale doodsoorzaak stierven werden van de cardiale analyses uitgesloten. Dit betekent dat als 'non-cases' alleen die 2251 mannen werden opgenomen die ten tijde van de screening in cardiovasculair opzicht gezond waren en gedurende de 9 1/2 jaar follow-up geen hartijden kregen. Het aantal cases van de cardiale mortaliteit en morbiditeit bedroeg respectievelijk 69 en 94 . Ten aanzien van het eindpunt totale mortaliteit werd gecorrigeerd voor leeftijd, al dan niet roken, en burgerlijke staat (gehuwd-ongehuwd). Voor de cardiale eindpunten werden hieraan de variabelen Queteletindex, diastolische bloeddruk en cholesterol toegevoegd.

Voor de analyses van de afzonderlijke items werden de deelnemers in drie groepen ingedeeld. De eerste groep, die als referentiegroep diende, wordt gevormd door hen, die op de desbetreffende vraag zeiden dat dit hen helemaal niet beschreef. De tweede groep werd gevormd door hen, die een van de twee midden categorieën kozen. De derde groep werd gevormd door hen die zeiden dat de uitspraak hen zeer goed beschreef. Deze procedure werd gevolgd omdat de interesse vooral uitging naar de extreme groep. Een extreme score benadert immers het begrip 'vitale uitputting' het 
best. De analyses van de afzonderlijke items werden eveneens met het Cox regressiemodel uitgevoerd. Een belangrijke assumptie van dit model betreft de 'proportional hazards'. Deze assumptie houdt in dat de ratio van de hazard rates voor de verschillende niveau's van de onafhankelijke variabele constant over de tijd blijft. Deze assumptie wordt in het Cox model getoetst door de interactie tussen de expositie variabele en de tijd tussen de aanvang van het onderzoek en het optreden van een eindpunt op te nemen. De geschatte regressie coëfficiënt van deze interactieterm wordt getoetst op statistische significantie. Indien deze niet significant is bestaat er geen aanleiding een tijdsafhankelijk effect te veronderstellen. Indien zij wel significant is kunnen op basis van deze regressie coëfficiënt de hazard ratio's voor de verschillende follow-up perioden berekend worden. Omdat de interesse vooral uitging naar korte termijn effecten, werden de hazard ratios berekend voor een follow-up periode van telkens 10 maanden. De Cox regressie analyses werden uitgevoerd met de $2 \mathrm{~L}$-procedure van het BMDPpakket.

\subsection{RESULTATEN}

\section{De Reeder stress scale}

De factoranalyse liet zien dat alle vragen op én factor laadden. Deze factor verklaarde $36 \%$ van de totale variantie. De laagste lading bedroeg .35 (item 4), hetgeen laag is doch aanvaardbaar geacht kan worden.

Noch in de ongecorrigeerde noch in de gecorrigeerde Cox analyses werd een verband gevonden tussen de factorscores en een van de drie eindpunten. Stress, zoals gemeten door de factor, die de items gemeenschappelijk hebben, verhoogt de sterftekans of de kans op een hartinfarct dus niet.

\section{De afzonderlijke items}

Vijf van de zeven items bleken op geen enkele wijze samen te hangen met de sterftekans of het risico op een hartinfarct. Twee items bleken echter samen te hangen met de cardiale mortaliteit. $\mathrm{Zij}$, die zeiden in hun dagelijks werk vaak onder druk te staan hebben geen significant verhoogd risico op cardiale sterfte over de totale followup periode. Wel bleek uit zowel de ongecorrigeerde als de gecorrigeerde analyses dat er sprake was van een tijdsafhankelijke invloed. Bij nadere inspectie van het verloop van de rate-ratio's over de follow-up periode bleek dat zij die veel spanning in hun werk zeiden te ervaren 5.42 keer zoveel kans hadden om binnen 10 maanden aan hun hart te sterven terwijl dit gecorrigeerde risico op cardiale mortaliteit voor een followup periode van 20 maanden 3.63 bedroeg. 
Het item 'aan het eind van de dag ben ik lichamelijk en geestelijk volledig uitgeput' bleek niet samen te hangen met cardiale morbiditeit en met totale sterfte. Ook werd geen associatie gevonden met de cardiale mortaliteit over de totale follow-up periode. Wel werd in zowel de ongecorrigeerde als de gecorrigeerde analyses een sterk tijdsafhankelijk effect tussen deze vraag en de cardiale sterfte geconstateerd.

Zoals in tabellen 2 en 3 is af te lezen heeft de groep, die zich extreem uitgeput voelt een zeer sterk verhoogd risico op cardiale sterfte binnen de eerste veertig maanden van de follow-up periode. Het risico op cardiale sterfte binnen 10 maanden bleek ook significant verhoogd te zijn bij hen, die in de middengroep ('matig uitgeput') vielen. Dit effect verdween geleidelijk bij langere follow-up.

Tabel 2 Absolute aantallen cardiale sterfte per 10 maanden follow-up bij hen die zeggen zich aan het einde van de dag al dan niet uitgeput te voelen

\begin{tabular}{|l|c|r|c|c|}
\hline & Zeer uitgeput & Middengroep & Niet uitgeput & Geen informatie \\
\hline 10 mnd & 1 & 4 & 1 & \\
20 mnd & 2 & 3 & 1 & \\
30 mnd & 1 & 1 & 2 & 1 \\
40 mnd & & 4 & 2 & \\
50 mnd & & 4 & 2 & 1 \\
70 mnd & & 3 & 3 & 1 \\
80 mnd & & 5 & 4 & \\
90 mnd & 2 & 3 & 4 & \\
100 mnd & & 5 & 4 & \\
110 mnd & 133 & 2 & 3 & \\
\hline Aantal personen in analyse & & 1200 & 914 & \\
\hline
\end{tabular}

Tabel 3 Gecorrigeerde Hazard Ratios per tien maanden follow-up voor sterfte ten gevolge van cen hartinfarct bij hen die zeggen zich aan het einde van de dag zeer uitgeput of uitgeput te voelen, ten opzichte van hen, die dit niet aangeren

\begin{tabular}{|l|r|r|r|r|}
\hline & \multicolumn{3}{|l|}{ Zeer uitgeput } & \multicolumn{2}{l|}{ Uitgeput } \\
\cline { 2 - 5 } & Hazard Ratio & BI (95\%) & Hazard Ratio & BI (95\%) \\
\hline $10 \mathrm{mnd}$ & 8.96 & $1.84-43.57$ & 3.57 & $1.01-12.60$ \\
$20 \mathrm{mnd}$ & 6.33 & $1.61-24.92$ & 2.94 & $.91-9.46$ \\
$30 \mathrm{mnd}$ & 4.47 & $1.40-14.22$ & 2.42 & $.70-7.66$ \\
$40 \mathrm{mnd}$ & 3.16 & $1.19-8.39$ & 1.99 & $.59-6.70$ \\
$50 \mathrm{mnd}$ & 2.26 & $.96-5.29$ & 1.64 & $.43-6.27$ \\
$60 \mathrm{mnd}$ & 1.57 & $.70-3.52$ & 1.35 & $.29-6.18$ \\
$70 \mathrm{mnd}$ & 1.11 & $.47-2.60$ & 1.11 & $.19-6.30$ \\
$80 \mathrm{mnd}$ & .78 & $.29-2.08$ & .91 & $.13-6.57$ \\
$90 \mathrm{mnd}$ & .55 & $.17-1.76$ & .75 & $.08-6.97$ \\
$100 \mathrm{mnd}$ & .39 & $.10-1.54$ & .62 & $.05-7.48$ \\
$110 \mathrm{mnd}$ & .28 & $.05-1.37$ & .51 & $.03-8.09$ \\
\hline
\end{tabular}




\subsection{DISCUSSIE}

De analyses van de Reeder stress schaal lieten zien dat stress op deze wijze gemeten geen cardiovasculaire risico-indicator is. Zoals in de inleiding al angegeven werd, dateen de test uit een tijd, waarin men nog geloofde dat 'stress' een unidimensioneel begrip is. Zo maakt de Reeder stress schaal nog geen onderscheid tussen stabiele persoonlijkheidskenmerken (item 1) en problemen in de thuissituatie (item 4). De vragen over werk en gezin zijn zo algemeen gesteld, dat onbekend blijft waarnaar een positief antwoord excact verwijst. Wat de items gemeenschappelijk hebben moet geinterpreteerd worden als een vage, algemene geneigdheid tot klagen. Deze factor kan in elke klachtenlijst worden aangetroffen en is in de psychologie bekend onder de naam neuroticisme. "Neuroticism may be thought to represent a large and diffuse item domain, encompassing almost anything in the realm of unwell-being. This renders the definition of neuroticism and its synonyms broad to such a degree, that it can be considered uninformative ... aspecificy is the hallmark of neuroticism" (Bouwman 1987).

Neuroticisme is de bereidheid om op uitnodiging te klagen. Deze factor verklaart waarom klaagitems vrijwel altijd positief met elkaar correleren en tesamen een relatief consistente schaal vormen. Het is daarom niet bevreemdend dat de items van de Reeder schaal met elkaar samenhangen, terwijl slechts enkele met een cardiovasculair eindpunt samenhangen, het aspecifieke element van ieder item verklaart de interne samenhang, terwijl het specifieke, unieke deel de samenhang met een extern criterium, i.c. cardiale sterfte, verklaart.

Ook met betrekking tot het gevoel van geestelijke en lichamelijke uitputting kan men uit deze data geen conclusies trekken. Weliswaar bestond er een apriori vermoeden dat de extreem scorende groep verhoogde cardiale risico's heeft, reden waarom de analyses überhaupt werden uitgevoerd, doch het gaat hier ten principale om een aposteriori analyse. Bovendien werd geen associatie gevonden met cardiale morbiditeit, hetgeen wel verwacht was.

Ondanks de grote terughoudendheid, die men bij de interpretatie van deze resultaten in acht moet nemen, blijft het het noteren waard dat het relatief risico van een gevoel van uitputting zo hoog is op relatief korte termijn. De dalende trend van de hazard ratios suggereert dat er binnen het cohort een subgroep bestaat voor wie de toestand, waamaar deze gevoelens verwijzen, een sterk korte termijn risico inhoudt. De uitgeputte deelgroep met een somatisch verhoogde sterftekans zal dus snel uitsterven, zodat onder de uitgeputten een in cardiaal opzicht vrij gezonde groep overblijft. Van Doomen (1988) heeft geconstateerd dat vitaal uitgeputte personen op een sterke mentale belasting (i.c. de verdediging van een proefschrift) reageren met een toegenomen excretie van noradrenaline. Het zou kunnen zijn (maar dit is een speculatie) dat deze toegenomen excretie van noradrenaline bij personen wier endoteel beschadigd is of wier myocard door micronecrosen kwetsbaar is, kan leiden tot trombusvorming of fatale ritme stoornissen. 
Gevoelens van verlies van energie zijn het meest genoemde prodroom van de plotselinge dood. De interpretatie hiervan stuit op grote moeilijkheden. Niet alleen is deze klacht zo aspecifiek, ook de oorsprong is onbekend. Veel cardiologen zijn geneigd deze gevoelens toe te schrijven aan een verzwakt hart. Omdat zij, die bij de aanvang van de studie leden aan angina pectoris of al een infarct hadden doorgemaakt niet in de analyses werden opgenomen kan uitgesloten worden dat de gevonden samenhang berust op een klinisch manifest hartlijden. Wel bestaat de mogelijkheid dat de associatie berust op een niet-klinisch manifest hartlijden. Onbekend is ook of de fatale infarcten plotselinge infarcten waren. Het enige wat daarom te zeggen valt is dat de KRIS-studie een aanwijzing, maar geen bewijs bevat dat het fatale infarct meestal niet optreedt als een donderslag bij heldere hemel, maar voorafgegaan wordt door uitputtingsgevoelens. Het prospectief onderzoek sluit daarmee aan op de talrijke retrospectieve studies, die hier over gedaan zijn.

Met betrekking tot andere items van de Reeder stress schaal bestonden er geen expliciete vermoedens omtrent hun samenhang met toekomstig hartlijden. Het is de moeite van het noteren waard dat het item 'in mijn dagelijkse werk sta ik vaak onder druk' geassocieerd was met cardiale sterfte. Vanwege het aposteriori karakter van deze analyse wordt hieraan geen enkele conclusie verbonden.

\subsection{ABSTRACT}

This paper reports about the association between stress, as assessed by the Reeder stress scale and coronary heart disease as observed in the KRIS follow-up study. In this study 3365 males, aged 45-60 were screened for cardiovascular risk factors and followed during $91 / 2$ years. Scores on the Reeder scale were not associated with future coronary heart disease. An analysis of the separate items by Cox's regression analysis showed that the item 'I am exhausted mentally and physically at the end of the day' was associated with an increased risk for cardiac death during the beginning of the follow-up period. The Hazard Ratio's were respectively 8.96, 6.33, 4.77 and 3.16. These data support the belief that exhaustion belongs to the precursors of cardiac death.

\subsection{LITERATUUR}

Alonzo, A., A. Simon \& M. Feinleib, Prodromata of myocardial infarction and sudden death. Circulation 52 (1975) 1056-1062.

Appels, A. \& P. Mulder, A questionnaire to assess premonitory symptoms of myocardial infarction. Int. J. Cardiol. 17 (1987) 15-24. 
Appels, A. \& P. Mulder, Excess fatigue as a precursor of myocardial infarction. European Heart J. 9 (1988) 758-764.

Appels, A., F. Otten, P. Mulder \& F. Sturmans, De KRIS follow-up study I. Methoden van dataverzameling. T. Soc. Gezondheidsz. 66 (1988) 18-21.

Bouman, T., The measurement of depression with questionnaires. Dissertatie, Groningen 1987.

Doornen, L. van, Physiological stress reactivity. Dissertatie, Amsterdam 1988.

Frazer, G.E., Sudden death in Auckland. Austr. New Zealand J. Med. 8 (1978) 490-499.

Glasunov, I.S., J.E. Dowd, A. Baubiniene, V. Grabauskas, F. Sturmans \& J.H. Schuurman, (eds), The Kaunas Rotterdam Intervention Study. Elsevier/North Holland, Amsterdam 1981 .

Kinlen, L.J., Incidence and presentation of myocardial infarction in an English community. Br. Heart J. 35 (1973) 616-622.

Kuller, L.H., Prodromata of sudden death and myocardial infarction. Avd. Cardiol. 25 (1978) 61-72.

Reeder, L.C., J.M. Chapman \& A.H. Coulson, Socio-environmental stress, tranquilizers and cardiovascular disease. Excerpta Medica International Congress series No. 182. Proceedings of an international symposium, Baia Dominia, May 1968, pp. 226-238.

Rissanen, V.,M. Romo \& P. Siltanen, Premonitory symptoms and stress factors preceeding sudden death from ischaemic heart disease. Act. Med. Scand. 204 (1978) 389-396. 


\title{
HOOFDSTUK 6 \\ De KRIS follow-up studie VIII: De relatie tussen familiale belasting en hart- en vaatziekten
}

\author{
(F. Otten, A.Appels, F. Sturmans, J. Schuurman, P. Mulder)
}

(T. Soc. Gezondheidsz. 1990; 68: 427-432)

Met behulp van de KRIS follow-up gegevens van 3365 Rotterdamse mannen met een leefiijd van 45-60 jaar werd onderzocht of familiale belasting, geoperationaliseerd als de gerapporteerde aanwezigheid van respectievelijk een myocardinfarct, een hersenbloeding, of een plotselinge dood bij naaste familieleden van invloed is op het optreden van hart-en vaatziekten. Mannen waarvan zowel een der ouders als een van de broers of zussen een hartinfarct of plotselinge dood had doorgemaakt. bleken hogere cholesterolwaarden te hebben terwijl bij hen ook een verhoogde bloeddruk werd geconstateerd.

Een positieve familie-anamnese bleek het risico op een al dan niet fataal infarct te verhogen. Parentale belasting verhoogt het risico met ongeveer $20 \%$, belasting via broers of zussen verdubbelt het risico, terwijl het risico bij dubbel belaste mannen met ongeveer $150 \%$ verhoogd is. De bevindingen onderstrepen het helang om hij het afnemen van een anamnese ook naar de ziektegeschiedenis van broers of zussen te vragen. Zij wijzen tevens op het belang van omgevingsfactoren.

\subsection{INLEIDING}

In verschillende studies is geconstateerd dat personen, waarvan een familielid een hartinfarct heeft doorgemaakt, een verhoogde kans op een coronaire hartaandoening hebben. De meeste gegevens hierover zijn afkomstig van case-control onderzoek (Phillips 1974, Morrison 1980, Thodarson 1979). In vergelijking tot het onderzoek naar somatische risicofactoren is over de betekenis van familiale belasting relatief weinig prospectief onderzoek gedaan. Acht prospectieve studies konden worden getraceerd, waarvan er vijf zijn uitgevoerd bij mannen (Scholtz 1975, Cambien 1980, Snowden 1982, Schulte 1980, Nyboe 1989), een bij vrouwen (Colditz 1986) en twee zowel bij mannen als vrouwen (Barret-Connor 1984, Hopkins 1988). In deze studies werd een positieve samenhang tussen familiale belasting en het optreden van een al dan niet fataal infarct geconstateerd. Het relatieve risico varieer tussen 1.5 en 1.8 . Sommi- 
ge studies hebben in hun analyses een onderscheid gemaakt in de leeftijd, waarop het infarct bij het familielid bij de deelnemers aan het onderzoek optrad. In enkele gevallen werd daarbij gevonden dat het risico het grootst is wanneer een familielid voor zijn zestigste levensjaar een infarct kreeg. Sommige studies constateerden dat de familiale belasting alleen een risicofactor is bij mannen jonger dan 50 jaar. Deze bevindingen zijn echter niet consistent. Verschillende studies hebben deze aanvullende analyses niet gedaan omdat de leeftijd waarop het familielid een infarct kreeg onbekend was.

Vijf van de acht prospectieve studies hebben alleen geïnformeerd naar het voorkomen van een infarct bij één van de ouders, twee studies vroegen zowel naar een cardiale geschiedenis bij ouders en broers of zussen, terwijl een studie zich beperkte tot familiale belasting via een broer. De twee studies waarin naar een cardiale geschiedenis bij ouders en broers of zussen gevraagd werd hebben geen aparte analyses gedaan over de vraag of een cardiale geschiedenis bij én der ouders hetzelfde risico met zich meebrengt als een cardiale geschiedenis bij een broer of zus. In één van deze twee studies waren de aantallen te gering om deze berekening te kunnen uitvoeren (Hopkins 1988). De andere studie noteerde slechts of een ouder of broer of zus een infarct had doorgemaakt en combineerde deze informatie bij de aanvang van het onderzoek in én index, zodat separate analyses niet mogelijk waren (Barret-Connor 1984).

Beperking van de analyses tot een cardiale geschiedenis bij een van de ouders heeft als voordeel dat men geen rekening behoeft te houden met het aantal broers of zussen. Een nadeel is dat onbekend blijft of belasting via de ouders of via broers of zussen een verschillend risico hebben. Beantwoording van deze vraag is niet onbelangrijk voor het verwerven van een dieper inzicht in het relatieve belang van genetische en omgevingsfactoren.

Met behulp van de gegevens van de KRIS follow-up studie kan worden nagegaan welke vorm van familiale belasting samenhangt met de cardiovasculaire risicofactoren bloeddruk en cholesterol en welke vorm van familiale belasting de kans op een al dan niet fataal infarct of enige coronaire aandoening (infarct of angina pectoris) verhoogt.

\subsection{METHODEN}

Gedurende de periode 1972-1974 deden in het kader van de Kaunas Rotterdam Intervention Study (KRIS) 3365 Rotterdamse mannen in de leeftijd van 45-60 jaar mee aan een cardiovasculair screeningsonderzoek. Bij dit cohort konden voor een follow-up van 9 1/2 jaar de incidentie van hart- en vaatziekten en de verschillende sterfte-oorzaken geregistreerd worden. Voor nadere details wordt verwezen naar Glasunov e.a. (1982) en Appels e.a. (1988). Bij het screeningsonderzoek is ook gevraagd naar het voorkomen van een hartinfarct, hersenbloeding of plotselinge dood bij een van de 
ouders of bij een van de broers of zussen. Met behulp van deze gegevens konden de volgende vraagstellingen beantwoord worden:

1. Bestaat er een samenhang tussen familiale belasting en de diastolische bloeddruk en het plasmacholesterolgehalte?

2. Verhoogt de familiale belasting de kans op een al dan niet fatale coronaire aandoening?

Ter beantwoording van de eerste onderzoeksvraagstelling werden eenweg variatieanalyses uitgevoerd, waarbij alle 3365 deelnemers aan het screeningsonderzoek betrokken werden. Voor de beantwoording van de tweede onderzoeksvraag werden deelnemers met een cardiovasculaire voorgeschiedenis van verdere analyses uitgesloten. De cases werden onderverdeeld in vier groepen:

- Cardiale morbiditeit (niet fataal infarct; $N=94$ );

- Cardiale mortaliteit (fataal infarct; $N=69$ );

- Infarctincidentie (fataal of niet-fataal infarct; $N=163$ ) en

- Coronaire hartziekte (alle infarcten + angina pectoris of bypass operatie in de follow-up periode; $N=209$ )

De 'non-cases' werden gevormd door de 2251 mannen, die tijdens de follow-up periode in cardiovasculair opzicht gezond bleven en in leven waren. Familiale belasting werd onderverdeeld in:

A door één of beide ouders belast,

B door broers en/of zussen belast,

C zowel door ouders als broers of zussen belast (dubbel) en

D onbelast.

De laatste groep vormde de referentiegroep.

Met behulp van Cox regressie analyse werd het effect van de drie typen belasting op cardiale morbiditeit en mortaliteit bepaald. Aangezien het niet bekend is of mannen die aan een infarct overleden eerder een infarct hadden doorgemaakt en het tijdstip waarop angina pectoris voor het eerst optrad onbekend is, werden de analyses met betrekking tot de eindpunten infarctincidentie en coronaire hartziekten uitgevoerd met behulp van het logistische regressiemodel.

In alle analyses werd gecorrigeerd voor leeftijd, al dan niet roken, burgerlijke staat (al dan niet gehuwd), Queteletindex, diastolische bloeddruk en cholesterol. Tevens werd gecontroleerd voor het aantal broers en zussen omdat de kans op belasting via broers en zussen mede afhangt van het aantal.

Zowel bij het gebruik van het Cox als het logistische regressiemodel werd met behulp van een likelihood-ratio-test nagegaan of het model met de $1^{\mathbf{e}}$ orde interactie tussen familiale belasting en het aantal broers of zussen adequater was dan het model zonder deze interactie. Voor de overige interacties werd een conservatievere toetsingsprocedure aangehouden. Per eindpunt werd aan de hand van een likelihood ratio-test bepaald of een model met daarin alle eerste orde interacties tussen de drie vormen van familiale belasting en de controle variabelen de data beter beschrijft dan een model 
waarin de interacties zijn weggelaten. In het geval van een significante likelihood ratio werden de relevante $1^{\mathbf{e}}$ orde interacties met een stapsgewijze procedure opgespoord.

Alle Cox en logische regressie analyses zijn uitgevoerd met respectievelijk de $2 \mathrm{~L}$ en de LR procedure van het BMDP pakket.

\subsection{RESULTATEN}

In tabel 1 worden de frequentieverdelingen gepresenteerd voor de aan- of afwezigheid van respectievelijk een myocardinfarct, een hersenbloeding en plotselinge dood bij de naaste familieleden bij de aanvang van de studie. Het percentage mannen met een positieve parentale familiegeschiedenis komt goed overeen met de bevindingen van de andere prospectieve studies. Tabel 2 laat zien dat er een significant verschil bestaat in diastolische bloeddruk tussen de groepen, die al dan niet belast zijn met een hartinfarct in de familie. Tabel 3 laat zien dat de groepsgemiddelden van zowel de familiale infarct- als de plotselinge dood belasting statistisch significant van het algemene plasmacholesterol-gemiddelde verschillen. Met behulp van de Scheffé-methode (Pedhazur 1982) werd voor deze associaties post hoc vastgesteld welke groepen precies van elkaar verschillen. Met betrekking tot de diastolische bloeddruk bleek alleen het contrast tussen de onbelaste mannen en de groep van mannen met ouders én broers of zussen met een myocardinfarct statistisch significant te zijn en wel zodanig dat de dubbel belaste groep een hoger gemiddelde bloeddruk dan de onbelaste groep had. Met betrekking tot cholesterol werd geconstateerd dat voor het kenmerk infarctbelasting de onbelaste mannen een significant lager cholesterolgehalte hadden dan achtereenvolgens de parentaal belaste mannen, de via broers of zussen belaste mannen en de dubbel belaste mannen.

Verder werd voor het kenmerk plotselinge dood een significant contrast tussen onbelaste mannen en mannen met een belasting via broers of zussen vastgesteld. Bij de hierboven beschreven verschillen moet aangetekend worden dat de verschillen, hoewel statistisch significant, in absolute termen niet groot zijn.

Tabel I Frequentieverdeling van cardiovasculaire belasting in de familie

\begin{tabular}{|l|r|r|r|r|r|r|}
\hline & \multicolumn{2}{|c|}{ Hartinfarct } & \multicolumn{2}{c|}{ Plots. dood } & \multicolumn{2}{c|}{ Hersenbloeding } \\
\hline & $\mathrm{N}$ & $\%$ & $\mathrm{~N}$ & $\%$ & $\mathrm{~N}$ & $\%$ \\
\hline Geen belasting & 2303 & 68 & 2450 & 73 & 2565 & 76 \\
Eên of beide ouders & 548 & 16 & 609 & 18 & 571 & 17 \\
Broers of zus & 249 & 8 & 124 & 4 & 71 & 2 \\
Ouders en broer of zus & 93 & 3 & 61 & 2 & 16 & 1 \\
Geen informatie & 172 & 5 & 121 & 3 & 142 & 4 \\
\hline Totaal & 3365 & 100 & 3365 & 100 & 3365 & 100 \\
\hline
\end{tabular}


Tabel 2 Gemiddelde waarden van diastolische bloeddruk ( $m m \mathbf{H g}$ ) bij verschillende vormen van cardiovasculaire belasting in de familie

\begin{tabular}{|l|r|r|r|}
\hline & Hartinfarct & Plotselinge dood & Hersenbloeding \\
\hline Onbelast & 79.6 & 79.7 & 79.9 \\
Ouders & 80.4 & 80.8 & 80.4 \\
Broers/zussen & 80.8 & 80.7 & 81.3 \\
Dubbel belast & 83.4 & 81.7 & 79.8 \\
& & & \\
F & 3.83 & 1.83 & .63 \\
p & .01 & .14 & .60 \\
\hline
\end{tabular}

Tabel 3 Gemiddelde waarden van cholesterol $(\mathrm{mg} / 100 \mathrm{ml})$ bij verschillende vormen van cardiovasculaire belasting in de familie

\begin{tabular}{|l|r|r|r|}
\hline & Hartinfarct & Plotselinge dood & Hersenbloreding \\
\hline Onbelast & 200.1 & 200.5 & 201.6 \\
Ouders & 203.4 & 201.9 & 200.5 \\
Broers/zussen & 203.3 & 211.5 & 199.9 \\
Dubbel belast & 213.0 & 206.9 & 191.1 \\
& & & \\
F & 5.55 & 4.80 & .67 \\
P & .00 & .00 & .57 \\
\hline
\end{tabular}

Tabel 4 toont de percentages opgetreden eindpunten per afzonderlijke categorie van de drie vormen van familiale belasting. Omdat, zoals in de methoden paragraaf reeds werd uiteengezet, per cardiaal eindpunt het totaal aantal analyse-eenheden verschillend is, zijn de in deze tabel gepresenteerde percentages cardiale sterfte en cardiale mortbiditeit niet (rijgewijs) sommeerbaar tot het percentage fatale of niet-fatale infarcten (infarctincidentie). Tabel 4 makt ten aanzien van de kenmerken infarct en plotselinge dood belasting een duidelijke trend zichtbaar. Behoudens een enkele uitzondering stijgt in vergelijking tot onbelaste mannen het percentage opgetreden eindpunten telkens wanneer in volgorde de mannen met alleen een parentale belasting, de mannen die alleen via broers of zussen belast zijn en mannen die dubbel belast zijn, bekeken worden. Opvallend is dat bij mannen waar in de familie een hartinfarct of plotselinge dood voorkwam voor alle eindpunten geldt dat meer events voorkwamen bij mannen die via broers of zussen belast zijn dan via één van de ouders.

Op één uitzondering na worden de hoogste percentages geconstateerd bij mannen met een dubbele belasting.

Zoals boven aangegeven startten de multivariate analyses met een onderzoek naar het mogelijke effect van het aantal broers en zussen. Hierbij werden geen significante interacties aangetroffen. Vervolgens werd nagegaan of er significante interacties tussen de drie typen familiale belasting en een van de controle variabelen op de eindpunten bestonden. Dit bleek niet het geval. 
Tabel 4 Incidentie van cardiale aandoeningen bij verschillende vormen van familiale belasting (percentages)

\begin{tabular}{|l|c|c|c|c|}
\hline $\begin{array}{l}\text { Vorm familiale belas- } \\
\text { ting }\end{array}$ & Fataal infarct & $\begin{array}{c}\text { Eindpunt niet-fataal } \\
\text { infarct }\end{array}$ & Alle infarcten & $\begin{array}{c}\text { Infarct en/of angi- } \\
\text { na/bypass }\end{array}$ \\
\hline Hartinfarct & & & & \\
Onbelast & 2.6 & 3.4 & 5.8 & 7.1 \\
Ouders & 2.1 & 4.8 & 6.8 & 8.6 \\
Broers/zussen & 6.1 & 8.1 & 13.3 & 17.9 \\
Dubbel belast & 10.0 & 8.5 & 16.9 & 20.6 \\
Plotselinge dood & & & & \\
Onbelast & 2.9 & 3.4 & 6.1 & 7.8 \\
Ouders & 2.6 & 5.2 & 7.5 & 16.7 \\
Broers/zussen & 6.8 & 6.8 & 12.8 & 21.4 \\
Dubbel belast & 5.7 & 10.8 & 15.4 & \\
Hersenbloeding & & & & 7.8 \\
Onbelast & 2.7 & 3.7 & 6.3 & 10.6 \\
Ouders & 3.9 & 5.4 & 8.8 & 15.4 \\
Broers/zussen & 0.0 & 8.3 & 8.3 & 16.7 \\
Dubbel belast & 16.7 & 0.0 & 16.7 & \\
\hline
\end{tabular}

Tabel 5 De relatieve risico's op en fataal infarct voor verschillende vormen van cardiovasculaire belasting in de familie, gecorrigeerd voor leeftijd, burgerlijke staat, bloeddruk, cholesterol en roken

\begin{tabular}{|c|c|c|c|c|}
\hline Belasting door & RR & $95 \% \mathrm{BI}$ & Wald $X^{2}$ & p \\
\hline Hartinfarct & & & \multirow{4}{*}{10.67} & \multirow{4}{*}{.01} \\
\hline Ouders & .82 & $.38-1.74$ & & \\
\hline Broers/zussen & 2.09 & $.98-4.45$ & & \\
\hline Dubbel helast & 3.23 & $1.35-7.71$ & & \\
\hline Plotselinge dood & & & \multirow{4}{*}{3.49} & \multirow{4}{*}{.31} \\
\hline Ouders & .83 & $.43-1.61$ & & \\
\hline Broers/zussen & 2.04 & $.81-5.17$ & & \\
\hline Dubbel belast & 1.92 & $.47-7.93$ & & \\
\hline Hersenbloeding & & & \multirow{3}{*}{9.40} & \multirow{3}{*}{.01} \\
\hline Ouders & 1.43 & $.80-2.55$ & & \\
\hline Dubbel belast & 8.40 & $2.20-35.02$ & & \\
\hline
\end{tabular}

De voor confounding gecorrigeerde associaties tussen de drie vormen van familiale belasting afzonderlijk en de vier eindpunten worden in de tabellen $5 \mathrm{v} / \mathrm{m} 8$ gepresenteerd. Zoals tabel 4 liet zien bleek met betrekking tot het kenmerk hersenbloeding belasting niemand van de via broers of zussen belaste mannen een fataal hartinfarct en niemand van de dubbel belaste mannen een niet-fataal infarct te hebben gehad. Hantering van deze categorieën in de Cox-regressieanalyse maakt een mathematische oplossing onmogelijk. Daarom werden deze categorieën uitgesloten van de desbetreffende Cox analyses (zie tabel 5 en 6). 
Tabel 6 De relatieve risico's op een niet-fatagl infarct voor verschillende vormen van cardiovasculaire belasting in de familie, gecorrigeerd voor leeftijd, burgerlijke staat, bloeddruk, cholesterol en roken

\begin{tabular}{|l|c|c|c|c|}
\hline Belasting door & RR & $95 \%$ Bl & Wald X & p \\
\hline Hartinfarct & 1.47 & $.87-2.48$ & 6.43 & .09 \\
Ouders & 2.14 & $1.11-4.11$ & & \\
Broers/zussen & 1.53 & $.59-3.95$ & & \\
Dubbe! belast & & $.89-2.36$ & 6.49 & .07 \\
Plotselinge dood & 1.45 & $.61-3.81$ & & \\
Ouders & 1.52 & $1.18-9.01$ & & .15 \\
Broers/zussen & 3.26 & $.99-2.11$ & 3.73 & \\
Dubbel belast & 1.45 & $.42-3.12$ & & \\
Hersenbloeding & 1.15 & & & \\
Ouders & &
\end{tabular}

Familiale belasting met een hartinfarct bij een van de ouders blijkt het risico op een al dan niet fataal infarct of een coronaire aandoening niet of nauwelijks te doen stijgen. Bij een afzonderlijke analyse op fatale en niet-fatale infarcten veranderde dit beeld niet. Via broers of zussen belaste mannen bleken een hoger risico op een al dan niet fataal infarct te hebben $(R R=2.16)$ en op een coronaire aandoening $(R R=2.58)$.

Een dubbele belasting met een infarct deed dit relatieve risico licht stijgen (respectievelijk 2.51 en 2.66). De afzonderlijke analyses voor fatale en niet-fatale infarcten toonden dat familiale belasting met een hartinfarct vooral de kans op een fataal infarct vergroot. Bij via broers of zussen belaste mannen was het relatieve risico 2.09 (.98-4.45) en bij dubbel belaste mannen 3.23 (1.35-7.71).

Familiale belasting met een plotselinge dood bij éen van de ouders bleek de kans op een infarct of een andere cardiale aandoening niet te verhogen. Mannen waarvan een broer of zus plotseling overleden was, hadden meer kans op een infarct of cardiale gebeurtenis $(R R=1.92)$, terwijl er een tendens gevonden werd dat dubbel belaste mannen meer risico op een infarct hebben $(R R=2.90)$ of op een cardiale aandoening $(R R=3.17)$.

Familiale belasting met een hersenbloeding bleek een zwak positief verband met de cardiale eindpunten te hebben. In de afzonderlijke analyses werd gevonden dat in dit opzicht dubbel belaste mannen een grote kans op een fataal infarct hadden $(R R=8.40)$. Het zeer brede betrouwbaarheidinterval (2.02-35.02) geeft aan dat de schatting van dit relatieve risico vrij onnauwkeurig is.

Tot de familiale belasting wordt door sommige auteurs ook diabetes gerekend (Rissanen 1979). Daarom werd ook onderzocht of het voorkomen van diabetes bij ouders en/of broers en zussen de kans op het meemaken van een der eindpunten verhoogde. Dit bleek niet het geval te zijn. 
Tabel 7 De relatieve risico's op en al dan niet fatal infarct voor verschillende vormen van cardiovasculaire belasting in de familie, gecorrigeerd voor leeftijd, burgerlijke staat, Queteletindex, bloeddruk, cholesterol en roken

\begin{tabular}{|l|c|c|c|c|}
\hline Belasting door & $\mathrm{RR}$ & $95 \% \mathrm{BI}$ & Likeli-hoodratio & $\mathrm{P}$ \\
\hline Hartinfarct & & & & .01 \\
Ouders & 1.20 & $.76-1.87$ & 11.52 & \\
Broers/zussen & 2.16 & $1.26-3.71$ & & .12 \\
Dubbel belast & 2.51 & $1.23-5.09$ & & \\
Plotselinge dood & 1.18 & $.78-1.78$ & 5.89 & .14 \\
Ouders & 1.67 & $.79-3.50$ & & \\
Broers/zussen & 2.90 & $1.16-7.25$ & & \\
Dubbel belast & & & & \\
Hersenbloeding & 1.48 & $.99-2.21$ & 5.50 & \\
Ouders & 1.32 & $.45-3.82$ & & \\
Broers/zussen & 3.84 & $.81-18.27$ & & \\
Dubbel belast & & & & \\
\hline
\end{tabular}

Tabel 8 De relatieve risico's op een coronaire aandoening (infarct, bypass, angina) voor verschillende vormen van cardiovasculaire belasting in de familie, gecorrigeerd voor leeftijd, burgerlijke staat, bloeddruk, cholesterol en roken

\begin{tabular}{|c|c|c|c|c|}
\hline Belasting door & RR & $95 \% \mathrm{BI}$ & Likelihoodratio & $\mathrm{p}$ \\
\hline Hartinfarct & & & \multirow{4}{*}{19.95} & \multirow{4}{*}{.00} \\
\hline Ouders & 1.25 & $.84-1.86$ & & \\
\hline Broers/zussen & 2.58 & $1.61-4.11$ & & \\
\hline Dubbel belast & 2.66 & $1.40-5.04$ & & \\
\hline Plotselinge dood & & & \multirow{3}{*}{10.17} & \multirow{4}{*}{.02} \\
\hline Ouders & 1.10 & $.75-1.58$ & & \\
\hline Broers/zussen & 1.92 & $1.02-3.61$ & & \\
\hline Dubbel belast & 3.17 & $1.46-6.87$ & \multirow{5}{*}{6.59} & \\
\hline Hersenbloeding & & & & \multirow{4}{*}{.09} \\
\hline Ouders & 1.41 & $.98-2.02$ & & \\
\hline Broers/zussen & 1.98 & $.90-4.38$ & & \\
\hline Dubbel belast & 2.82 & $.60-13.32$ & & \\
\hline
\end{tabular}

\subsection{DISCUSSIE}

De bevindingen van deze studie bevestigen dat bij mannen die een familielid hebben die een al dan niet fataal infarct heeft doorgemaakt een hogere diastolische bloeddruk en hogere cholesterol waarden worden aangetroffen.

Familiaal belaste mannen blijken ook een hoger risico op een al dan niet fataal infarct te hebben. Dit verhoogde risico lijkt zich echter alleen voor te doen wanneer de positieve familiegeschiedenis ook een cardiovasculaire aandoening bij een van de broers of zussen bevat. 
De kans om familiaal belast te zijn neemt toe wanneer het gezin groot is en de respondent binnen het gezin tot de jongsten behoort. De database van de KRIS-studie bevat geen informatie over de leeftijd van broers of zussen noch over het moment, waarop een al dan niet fataal infarct bij hen optrad. Als gevolg hiervan kan de expositie aan familiale belasting niet geheel zuiver berekend worden. Dit werd gedeeltelijk ondervangen door het aantal broers en zussen als covariaat in de berekeningen op te nemen. Zoals boven aangegeven werd nergens een significante interactie gevonden. Een daarvan, namelijk de kans op cardiale mortaliteit bij belasting door een infarct bij broers of zussen, was echter bijna significant. Daarom werden voor het eindpunt cardiale sterfte aanvullende analyses uitgevoerd. Daarbij bleek het risico sterker bij mannen met zeven of meer broers of zussen. Deze bevinding geeft aan dat het aantal broers of zussen de schatting van het relatieve risico weliswaar enigermate beïnvloedt doch dat de vertekening die hierdoor optreedt gering is.

In de KRIS studie zijn geen gegevens verzameld over de leeftijd waarop een familielid een hartinfarct kreeg. Daarom was het niet mogelijk om na te gaan of een infarct bij één van de ouders voor het vijftigste of zestigste levensjaar een groter risico voor de kinderen inhoudt dan een infarct op latere leeftijd. De studie van Colditz gaf aan dat vooral een infarct dat bij één der ouders op relatief jonge leeftijd optrad, het cardiale risico verhoogt. De gegevens van onderhavige studie suggereren dat een parentale geschiedenis het cardiale risico bij de kinderen slechts in lichte mate verhoogt. Het is dus mogelijk dat het risico onderschat wordt bij hen van wie de vader of moeder voor het zestigste levensjaar een infarct kreeg.

Ook informatie-bias kan de schattingen van het relatieve risico verhoogd hebben. Is de informatie van de respondenten wel correct? Gegeven het prospectieve design van deze studie kan men uitsluiten dat de informatie beïnvloed is door een 'recall bias'. Na een infarct gaan patiënten en hun familie vaak op zoek naar verklaringen en kan de herinnering van cardiale gebeurtenissen in de familie geactiveerd en misschien wel geconstrueerd worden. Dit maakt case-control sudie over familiale belasting minder betrouwbaar. In deze studie werd de familie-anamnese afgenomen voor het optreden van de cardiale gebeurtenis, zodat deze vertekening niet kan optreden.

Het kan niet helemaal worden uitgesloten dat de informatie over familiale belasting beïnvloed is doordat de interviewer in hetzelfde onderzoek ook de Rose Questionnaire ter bepaling van de eventuele aanwezigheid van angina pectoris afnam. Hij kon dus enige informatie hebben over de cardiale toestand van de patiënt. Indien dit geleid heeft tot een fout positieve classificatie met betrekking tot familiale belasting werd de deelnemer niet in de analyses opgenomen, omdat zij die blijkens hun antwoorden op de Rose Questionnaire angina pectoris hadden hiervan werden uitgesloten. Er bestaat echter een kans dat de interviewer zich bij twijfelgevallen kan hebben laten leiden door een negatieve Rose Questionnaire, waardoor het percentage onbelaste personen iets te hoog wordt ingeschat. De kans dat deze vorm van misclassificatie de data werkelijk beïnvloed lijkt klein, omdat de percentages van deelnemers met of zonder 
positieve familie-anamnese goed corresponderen met de gegevens van de andere prospectieve studies.

Over de validiteit van deze informatie heerst er grotere onzekerheid. Weten de respondenten werkelijk de doodsoorzaak van hun ouders en kennen zij de ziektegeschiedenis van hun broers en zussen? De mededelingen van de respondenten zijn niet geverifieerd. De hoogte van het relatieve risico moet dus voorzichtig geünterpreteerd worden.

De meest opvallende bevinding is dat familiale belasting slechts dan het risico op een al dan niet fataal infarct verhoogt, wanneer deze ook een infarct bij een van de broers of zussen omvat. Telkens zijn het de contrasten tussen onbelaste mannen en hen die hetzij via broers of zussen hetzij dubbel belast zijn, die het totale model significant maken. Een parentale belasting verhoogt het risico enigermate, doch dit toegenomen risico schommelt tussen de 10 en 45 procent en is zelfs negatief ten aanzien van de fatale infarcten. Wanneer een van de broers of zussen een infarct heeft gehad is het risico in alle analyses meer dan verdubbeld. Belasting met een cardiale dood bij broers of zussen doet het risico met 50 tot 100 procent stijgen. Het hoogste risico wordt aangetroffen bij mannen met een dubbele belasting. Op twee uitzonderingen na blijkt een dubbele belasting de kans op een al dan niet fataal infarct of coronaire aandoening meer dan te verdubbelen.

De aard van de familiale belasting beïnvloedt het beeld van de relatieve risico's slechts in geringe mate. De bevindingen van Colditz dat een positieve familieanamnese vooral de kans op een fataal infarct vergroot kan niet ondubbelzinnig worden gerepliceerd. Wellicht is dit verschil veroorzaakt doordat zijn studie betrekking heeft op vrouwen.

Zoals boven aangegeven, kunnen verschillende factoren de zuiverheid van de schatting van het relatieve risico negatief beïnvloed hebben. De conclusie wordt daarom in meer globale termen geformuleerd: een positieve familie-anamnese verhoogt het risico op een al dan niet fataal hartinfarct; parentale belasting verhoogt het risico met ongeveer $20 \%$, belasting via broers of zussen verdubbelt het risico, terwijl het risico bij dubbel belaste mannen met $150 \%$ verhoogd is.

Deze bevindingen tonen aan dat het voor de identificatie van personen met een hoog risico het tenminste even belangrijk is om naar de cardiale geschiedenis van broers en zussen te vragen als die van ouders. $\mathrm{Zij}$ geven tevens aan dat nader onderzoek gewenst is naar de betekenis van omgevingsfactoren, aangezien de genetische component zwakker lijkt dan al datgene wat familieleden naast hun genen gemeenschappelijk hebben. Aangezien de betekenis van familiale belasting via broers of zussen bleef bestaan na controle voor cholesterol, bloeddruk en roken moet men daarbij aan andere omgevingsfactoren denken dan aan eetgewoonten. 


\subsection{ABSTRACT}

This paper examines the influence of a reported positive family history of coronary heart disease upon the risk for myocardial infarction and angina pectoris in a sample of 3565 males, aged 45-60, who were followed during an avarage period of 9 1/2 years (Kaunas- Rotterdam Intervention Study). A positive family history increases the risk for a fatal or non-fatal myocardial infarction. A parental history increases the risk by about $100 \%$, while the risk among males with a 'double' history is increased by about $150 \%$. These results indicate that a medical anamnesis should include the family history of the brothers and sisters. They further stress the importance of environmental factors.

\subsection{LITERATUUR}

Appels, A., F. Otten, P. Mulder \& F. Sturmans, De KRIS follow-up studie I: Methoden van dataverzameling. T. Soc. Gezondheidsz. 66 (1988) 18-21.

Barret-Connor, E.M. \& Kay-Tee-Khaw, Family history of heart attack as independent predictor of death due to cardiovascular disease. Circulation 69 (1984) 1065-1069.

Cambien, F., J. Richard \& P. Ducimeteriere, Familial history of coronary heart disease and high blood pressure in relation to the prevalence of risk factors, and the incidence of coronary heart diseases. Rev. Epidemiol. Santé Publ. 28 (1980) 21-37.

Colditz, G.A., M. Stampfer, W. Willett, B. Rosner, F. Speizer et al., A prospective study of parental history of myocardial infarction and coronary heart disease in women. Am. J. Epidemiol. 123 (1986) 48-58.

Glasunov, I., J. Dowd, A. Baubiniene, V. Grabauskas, F. Sturmans \& J. Schuurman (eds.), The Kaunas Rotterdam Intervention Study. Elsevier/North Holland, Amsterdam 1981.

Hopkins, P., R. Williams, H. Kuida, B. Stults, S. Hunt et al., Family history as an independent risk factor for incident coronary artery disease in a high risk cohort in Utah. Am. J. Cardiol. 62 (1988) 703-704.

Kleinbaum, D., L. Kupper \& H. Morgenstem, Epidemiologic research: principles and quantitative methods. Lifetime Learning Publications, Belmont/Califomia 1982. 
Morrison, J., R. Horvitz \& P. Khoury, Parental history of coronary heart disease, hypertension, diabetes, and stroke: relationship to coronary heart disease risk factor variables in their adult children. Prev. Med. 9 (1980) 773-786.

Nyboe, J., G. Jensen, M. Appleyard \& P. Schnohr, Risk factors for acute myocardial infarction in Copenhagen I: hereditory, educational and socio-economic factors. Eur. Hear J. 4 (1989) 910-916.

Pedhazur, E., Multiple regression in behavioral research. Explanation and Prediction. CBS College Publishing, New York 1982.

Phillips, R., A. Libenfeld, E. Diamond \& A. Kagan, Frequency of coronary heart disease and cerebrovascular accidents in parents and sons of coronary heart disease index cases and controls. Am. J. Epidemiol. 100 (1974) 87-100.

Rissanen, A. \& E. Nikkilä, Aggregation of coronary risk factors in families of men with fatal and non-fatal coronary heart disease. Br. Heart J. 42 (1979) 373-380.

Schulte, H., Ergebnisse der Prospective cardiovascular Mūnster (PROGRAM) Studie. Sozial und Präventiv Medizin 33 (1988) 32-36.

Scholtz, R., R. Rosenman \& R. Brand, The relationship of parental history to the incidence of coronary heart disease in the Western Collaborative Group Study. Am. J. Epidemiol. 102 (1975) 350-356.

Snowden, C., P. McNamara \& R. Garrison, Predicting coronary heart disease in siblings - A multivariate assessment, The Framingham Heart Study, Am. J. Epidemiol. 115 (1982) 217-222.

Thordarson, O. \& S. Fridrikson, Aggregation of deaths from ischaemic heart disease among first and second degree relatives of 108 males and 42 females with myocardial infarction. Acta Med. Scand. 205 (1979) 492-500. 


\section{HOOFDSTUK 7 \\ De KRIS follow-up studie XII: \\ De relatie tussen lichamelijke inspanning \\ en ischemische hartziekten}

(Trefwoorden : lichamelijke inspanning, ischemische hartziekten, KRIS)

(F. Otten, J. Pool, A. Appels, F. Sturmans)

(In enigszins gewijzigde vorm geaccepteerd door T. Soc. Gezondheidsz.)

Gedurende 1972-1974 zijn in het kader van de Kaunas Rotterdam Intervention Study (KRIS) 3365 Ronerdamse mannen in de leeftijd van 45-59 jaar gescreend op cardiovasculaire risicofactoren. Dit cohort is gemiddeld $91 / 2$ jaar gevolgd. Met de KRISgegevens is onderzocht of lichamelijke inspanning omgekeerd gerelateerd is aan ischemische hartzieksen (IHZ). Lichamelijke inspanning werd geoperationaliseerd in vier variabelen: inspanning op het werk (index), inspanning in de vrije tijd (geen, gering, matig, veel), lopend en/of fietsend naar het werk gaan (niet, wel) en totale inspanning (index). In de analyses is steeds gecorrigeerd voor relevante cardiovasculaire risicofactoren. Minder zware lichamelijke inspanning in het beroep en minder zware totale lichamelijke inspanning van tien indexpunten gaan gepaard met $5 \%$ meer risico op een niet fataal of fataal hartinfarct. In beide gevallen ligt het $90 \%$ betrouwbaarheidinterval (BI) tussen 1,01 en 1,09. Minder zware totale inspanning van 10 indexpunsen correspondeert tevens met $4 \%$ meer risico op alle vormen van IHZ (90\% BI: 1,01-1,08). Tenslotte geldt dat mannen die noch fietsend noch lopend naar hun werk gaan een wee maal zo groot risico ( $90 \% \mathrm{BI}: 1,10-3,84)$ op angina pectoris of een 'bypass'operatie hebben dan mannen die dit wel doen. Ondanks beperkingen van meetkwaliteit van de KRIS-gegevens lijkt de conclusie gerechtvaardigd dat lichamelijke inspanning invers gerelateerd is aan ischemische hanziekten.

\subsection{INLEIDING}

De evaluatie van de beschermende werking van lichamelijke inspanning op (toekomstige) ischemische hartziekten is tot op heden een belangrijk en regelmatig terugkerend onderwerp binnen de cardiovasculaire epidemiologie.

Een van de eerste en tevens een van de bekendste cohortstudies naar deze inverse relatie is de, eind jaren veertig begin jaren vijftig gehouden 'London Busmen 
Study' (Morris e.a. 1953). In deze studie werden de van beroepswege lichamelijk minder actieve buschauffeurs met de actievere busconducteurs vergeleken. Na 2 jaar follow-up bleken de buschauffeurs een 1,42 maal zo groot risico op cardiale sterfte te hebben dan de busconducteurs. Hoewel in een later artikel van Morris (Morris e.a. 1956) deze bevinding werd gerelativeerd -het verschil in (over)gewicht tussen beide groepen was niet in de berekening meegenomen- fungeerde de 'London Busmen Study' feitelijk als een katalysator voor verder epidemiologisch onderzoek naar de invloed van lichamelijke inspanning op ischemische hartziekten. Een groot aantal studies bij diverse beroepen volgde. Zeer bekend zijn: de Amerikaanse studie onder spoorwegarbeiders (Taylor e.a. 1962, Taylor e.a. 1970), de Britse ambtenarenstudie (Chave e.a. 1978), de Israëlische studie onder kibboetsbewoners (Brunner e.a. 1974) en de Amerikaanse studie onder havenarbeiders in San Francisco (Paffenbarger e.a. 1977, Brand e.a. 1979). Deze studies kenmerken zich alle door de vergelijking van lichamelijk inactieve of minder actieve beroepsgroepen met actieve beroepsgroepen. Ze tonen vooral een verhoogd risico op cardiale sterfte en plotselinge dood bij de minder actieve beroepsgroepen.

Naast de impliciete meting van lichamelijke activiteit door bestudering van lichamelijk actieve en minder actieve beroepsgroepen zijn er tal van studies waarin de lichamelijke activiteit rechtstreeks met behulp van een vragenlijst wordt gemeten. Kenmerkend voor deze studies is de diverse wijze waarop naar allerhande dagelijkse verrichtingen wordt gevraagd.

Veelvuldig terugkerende onderwerpen met betrekking tot de dagelijkse verrichtingen zijn de lichamelijke inspanning op het werk en de lichamelijke inspanning in de vrije tijd en in mindere mate het sporten (als een verbijzondering van de vrijetijdsactiviteiten) alsmede de totaal verrichte lichamelijke inspanning (bijv. gedurende een etmaa). De voor een bepaalde vorm van lichamelijke activiteit van toepassing zijnde items worden doorgaans in een index samengevat. Deze index geefi uitdrukking aan het (geschatte) energieverbruik per tijdseenheid van de desbetreffende personen ten aanzien van de verrichtingen waarnaar gevraagd werd. Echter van goed uitgebalanceerde, aan externe criteria gevalideerde meetinstrumenten is tot dusver nog geen sprake. Voor uitgebreide inventarisaties van cardiovasculaire studies waarbij rechtstreekse metingen van lichamelijke inspanning zijn gehanteerd, wordt verwezen naar de overzichtsartikelen van Paffenbarger e.a. (1984), Kannel e.a. (1985) en Powell e.a. (1987). Deze artikelen laten zien dat lichamelijke inactiviteit, via vragenlijsten gemeten, doorgaans gepaard gaat met een (al dan niet significant) verhoogd risico op achtereenvolgens een myocardinfarct, plotselinge dood, cardiale sterfte en coronaire aandoeningen in het algemeen. De aard van de beïnvloedingsrelatie is te beschouwen als een (omgekeerde) 'dose-response' relatie (Berlin en Colditz 1990): hoe groter de lichamelijke inspanning des te kleiner het risico op een ischemische hartziekte. Indicaties voor een verhoogd risico op angina pectoris zijn evenwel spaarzaam. 
Nederlandse gegevens over de relatie tussen lichamelijke inspanning en harten vaatziekten zijn schaars. Ons bekend zijn alleen een case-control studie van Magnus e.a. (1979) en een Nederlandse bijdrage in de Zeven-landen-studie (Keys 1980). Uit de studie van Magnus blijkt dat mannen en vrouwen die regelmatig wandelen, fietsen of in de tuin werken ruim een twee maal zo kleine kans op een myocard-infarct hebben dan zij die dit niet doen. In de studie van Keys werd voor Nederland, maar ook voor de andere landen, geen empirische bevestiging gevonden voor de inverse relatie tussen lichamelijke inspanning (in het beroep) en hart- en vaatziekten.

Naast de genoemde Nederlandse studies zijn ook in het Rotterdamse deel van de Kaunas Rotterdam Intervention Study (KRIS) diverse vragen over lichamelijke inspanning opgenomen. Gelet op de beperktheid van de Nederlandse gegevens is het zinvol om met het KRIS-materiaal verder onderzoek te verrichten naar de relatie tussen lichamelijke inspanning en hart- en vaatziekten. Van de bevindingen wordt in dit artikel verslag gedaan.

\subsection{METHODEN}

\section{Onderzoekspopulatie en data}

Gedurende 1972 en 1974 werd in het kader van de KRIS-studie een aselecte steekproef van 3365 Rotterdamse mannen met een leeftijd van 45-59 jaar gescreend op cardiovasculaire risicofactoren. Met behulp van interviewers die de deelnemers begeleidden bij de invulling van gestandaardiseerde vragenlijsten werd gedurende de screening tevens informatie ingewonnen over sociologische, psychologische en gezondheidskundige kenmerken. Daarbij is onder meer gevraagd naar de verrichte activiteiten in achtereenvolgens het beroep, het woon-werk verkeer en de vrije tijd. Voor een complete beschrijving van deze studie wordt verwezen naar Glasunov e.a. (1981). In haar oorspronkelijke opzet is de KRIS-studie nooit bedoeld geweest als een follow-up onderzoek. Pas in het begin van de jaren tachtig werd besloten te onderzoeken welke kenmerken, zoals gemeten bij screening, samenhangen met cardiale mortaliteit en morbiditeit. Voor dit doel is in 1982 via het Centraal Bureau voor de Statistiek vastgesteld welke ex-deelnemers aan welke doodsoorzaak waren overleden. Daamaast is met een additioneel morbiditeitsonderzoek nagegaan welke nog in leven zijnde exdeelnemers een hartinfarct hadden gehad. Van de 350 mannen die waren overleden, zijn 112 aan een myocardinfarct gestorven. Verder hadden gedurende de $91 / 2$ jaar follow-up 31 mannen een als 'mogelijk' en 126 mannen een als 'waarschijnlijk' of 'zeker' geklassificeerd, niet fataal myocardinfarct doorgemaakt. Voorts hadden 21 mannen een bypassoperatie ondergaan en is bij 54 mannen angina pectoris opgetreden. Voor gedetailleerde informatie over het mortaliteits- en morbiditeitsonderzoek wordt verwezen naar Appels e.a. (1988). 


\section{Meting van lichamelijke inspanning}

De vragen naar lichamelijke inspanning die in de KRIS-studie zijn gesteld staan in tabel 1 .

De eerste 4 vragen hebben betrekking op de lichamelijke inspanning in de beroepsuitoefening. De daaropvolgende twee vragen geven uitdrukking aan de lichamelijke inspanning in het woon-werk verkeer. De laatste 4 vragen beschrijven de lichamelijke inspanning in de vrije tijd. De tabel geeft verder het percentage mannen waarop de desbetreffende activiteit van toepassing is en de gemiddelde bestede tijd voor deze categorieēn.

Tabel 1. Gestelde vragen naar lichamelijke inspanning in de beroepsuitoefening, in het woon-werk verkeer en in de vrije tijd

\begin{tabular}{|c|c|c|}
\hline & $\begin{array}{l}\text { Deel van de steek- } \\
\text { proef dat de desbe- } \\
\text { treffende activiteit } \\
\text { verrichr }\end{array}$ & $\begin{array}{l}\text { Gemiddelde beste- } \\
\text { de tijd I) } \\
\text { (uren/week) }\end{array}$ \\
\hline $\begin{array}{l}\text { Hoeveel uren per dag brengt U zittend door op het } \\
\text { werk? }\end{array}$ & $80 \%$ & 20 \\
\hline $\begin{array}{l}\text { Hoeveel uren per dag brengt U staand door op het } \\
\text { werk? }\end{array}$ & $72 \%$ & 15 \\
\hline $\begin{array}{l}\text { Hoeveel uren per dag besteedt U aan heen en weer } \\
\text { lopen op het werk? }\end{array}$ & $90 \%$ & 16 \\
\hline - Hoeveel uren per dag verricht U tilwerk op het werk? & $18 \%$ & 10 \\
\hline $\begin{array}{l}\text { - In het kader van woon-werk verkeer: hoeveel minu- } \\
\text { ten fietst U per dag? }\end{array}$ & $11 \%$ & 4 \\
\hline $\begin{array}{l}\text { In het kader van woon-werk verkeer: boeveel minu- } \\
\text { ten loopt U per dag? }\end{array}$ & $8 \%$ & 2 \\
\hline $\begin{array}{l}\text { Hoeveel uren in de week wandelt } U \text { in de vrije tijd } \\
\text { ('s winters)? }\end{array}$ & $69 \%$ & 4 \\
\hline $\begin{array}{l}\text { Hoeveel uren in de week wandelt } U \text { in de vrije tijd } \\
\text { ('s zomers)? }\end{array}$ & $76 \%$ & 5 \\
\hline $\begin{array}{l}\text { Hoeveel uren in de week verricht U matige of zware } \\
\text { activiteit in de vrije tijd ('s winters) }\end{array}$ & $25 \%$ & 4 \\
\hline $\begin{array}{l}\text { Hoeveel uren in de week verricht U matige of zware } \\
\text { activiteit in de vrije tijd ('s zomers)? }\end{array}$ & $41 \%$ & 5 \\
\hline
\end{tabular}

1) = gemiddelde van de wekelijks bestede uren voor degenen die de desbetreffende activiteit verrichten.

De in tabel 1 gepresenteerde vragen zijn ontleend aan een door Reiff e.a. (1964) ontwikkelde vragenlijst ter meting van de totale lichamelijke inspanning. Aan de hand van deze vragen berekende Reiff een index voor geleverde energie. De geleverde energie wordt hierbij weergegeven door een ratio van het metabolisme behorende tot 
een bepaalde activiteit met het basale metabolisme. Als tijdseenheid is de week genomen. Het bijbehorende conversieschema ter berekening van deze activiteitseenheden per week is in tabel 2 opgenomen.

Een zwak punt in de methode van Reiff is de toekenning van een uniforme activiteitseenheid voor ieder uur waarin niet gespecificeerde activiteiten zijn verricht. Het ligt voor de hand dat de variatie in lichamelijke inspanning voor deze uren aanzienlijk is. Ook de veronderstelde acht uren slaap zal nogal variëren tussen de onderzoekspersonen.

Tabel 2. Conversiescherna van Reiff

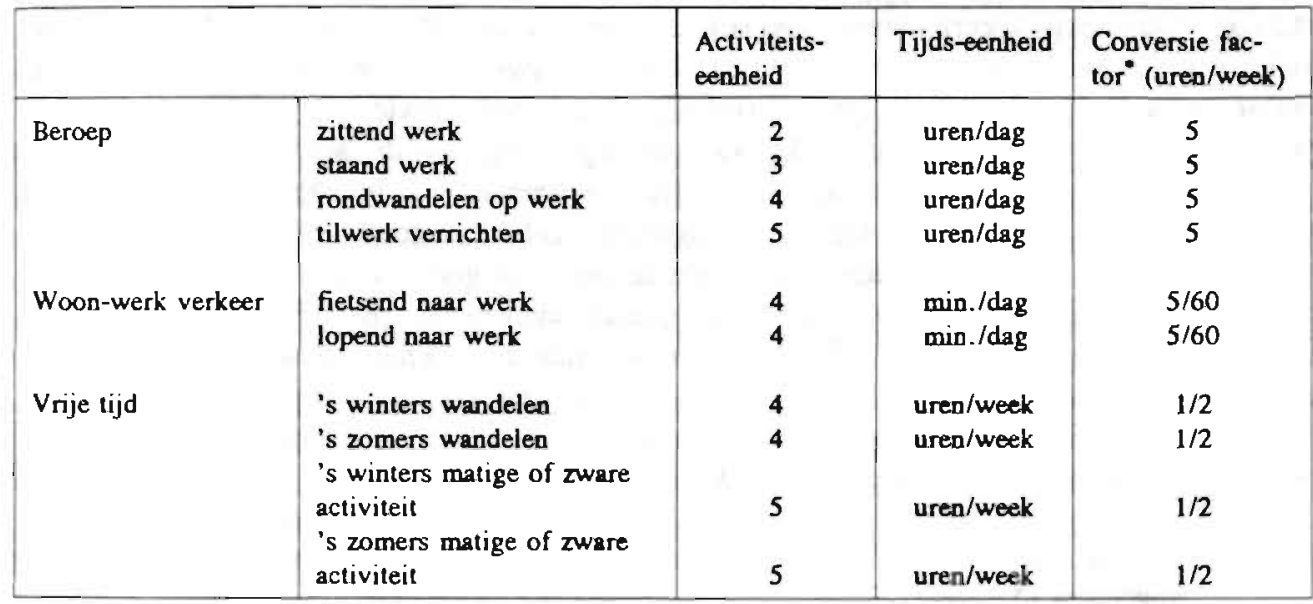

Andere assumpties: 1. I uur slaap $=1$ activiteitseenheid, verder wordt verondersteld dat iedere persoon 8 uur per dag slaapt

2. Aan ieder uur dat niet aan de opgesomde activiteiten en an slapen wordt besteed, worden 1,8 activiteitseenheden toegekend.

- Met betrekking tot de beroepsactiviteiten is gevrasgd naar het santal uren per dag dat men de desbetreffende inspanning verricht. Ora te komen tot wekelijkse waarde worden de opgegeven uren vermenigvuldigd met de conversiewaarde 5 . De activiteiten in verband met woon-werk verkeer zijn in minuten per dag opgegeven. Om tot de wekelijkse uren te komen, worden de opgegeven minuten eerst in uren omgezet (delen door 60) en vervolgend vermenigvuldigd met 5 . Met betrekking tot de vrije tijd is apart gevragd naar zomerse en winterse activiteiten in uren per week. Beide seizoenen worden geacht een half jaar te duren. Om tot het 'correcte' antal wekelijkse uren te komen, wordt de opgegeven tijd gedeeld door twee (conversiewarde 1/2).

Met andere woorden, opname van de veronderstelde activiteitseenheden voor die uren waarop de activiteitenvragen niet van toepassing zijn, tast de validiteit van de index aan. Daarom zijn alleen activiteitseenheden berekend voor die uren die door de 
desbetreffende vragen gedekt worden. Overeenkomstig deze gedachte zijn er vier variabelen samengesteld die uitdrukking geven aan lichamelijke inspanning. Onderscheiden wordt lichamelijke inspanning in de beroepsuitoefening, in het woon-werk verkeer en in de vrije tijd alsmede de totale lichamelijke inspanning verricht op voornoemde vlakken.

Optelling van de activiteitseenheden per week behorende tot de vier beroepsvragen resulteerde in een bij benadering normaal verdeelde continue variabele (gemiddelde $=130, s d=37$ ). Optelling van de activiteitseenheden per week behorende tot de vragen over woon-werk verkeer leverde daarentegen een zeer scheef verdeelde variabele op. De lichamelijke inspanning verricht ten behoeve van het woon-werk verkeer is daarom dichotoom weergegeven. De eerste categorie omvat die mannen die nooit naar het werk fietsen of lopen $(n=2733)$, de tweede categorie omvat diegenen die fietsend en/of lopend naar het werk gaan $(n=632)$. De bijbehorende activiteitseenheden per week zijn respectievelijk 0 en 1-33. Ook de optelling van de activiteitseenheden per week van de vier indicatoren van vrije tijd resulteerde in een zeer scheef verdeelde variabele. Deze variabele is tot vier categorieën gehercategoriseerd. $\mathrm{Er}$ is een onderscheid gemaakt in het verrichten van achtereenvolgens geen inspanning in de vrije tijd $(n=551)$, geringe inspanning $(n=1102)$, matige inspanning $(n=870)$ en veel inspanning in de vrije tijd $(\mathrm{n}=842)$. De bij deze indeling behorende activiteitseenheden per week zijn respectievelijk $0,1-13,14-26,27-280$. Optelling van de activiteitseenheden per week van alle inspanningsvragen resulteerde weer in een bij benadering normaal verdeelde continue variabele (gemiddelde $=151$, sd $=43$ ).

Tabel 3. Pearson correlaties van de onderlinge samenhang tussen de vier vormen van lichamelijke inspanning $(\mathrm{N}=3365)$

\begin{tabular}{|c|c|c|c|c|}
\hline & $\begin{array}{l}\text { Inspanning in } \\
\text { beroep }\end{array}$ & $\begin{array}{l}\text { Inspanning in } \\
\text { woon-werk ver- } \\
\text { keer }\end{array}$ & $\begin{array}{l}\text { Inspanning in } \\
\text { vrije tijd }\end{array}$ & Totale inspanning \\
\hline \multicolumn{5}{|l|}{ Inspanning in beroep } \\
\hline $\begin{array}{l}\text { Inspanning in woon-werk } \\
\text { verkeer }\end{array}$ & $\begin{array}{c}0.03 \\
(p=0,14)\end{array}$ & & & \\
\hline Inspanning in vrije tijd & $\begin{array}{c}-0.05 \\
(p=0,00)\end{array}$ & $\begin{array}{c}0.05 \\
(p=0,01)\end{array}$ & & \\
\hline Totale inspanning & $\begin{array}{c}0.85 \\
(p=0.00)\end{array}$ & $\begin{array}{c}0.15 \\
(p=0.00)\end{array}$ & $\begin{array}{c}0.34 \\
(p=0,00)\end{array}$ & \\
\hline
\end{tabular}

Tabel 3 toont de samenhangen tussen de 4 inspanningsvariabelen in de vorm van Pearson correlaties (alle variabelen zijn hierbij als intervalvariabelen beschouwd). Lichamelijke inspanning in het werk en totale lichamelijke inspanning hangen in hoge 
mate met elkaar samen. Inspanning in het woon-werk verkeer en inspanning in de vrije tijd voegt blijkbaar weinig toe aan de variatie op grond van de werkinspanning. Ondanks hun grote overeenkomst zijn werkinspanning en totale inspanning conceptueel verschillend van elkaar. Ze blijven in het verdere verloop van dit artikel dan ook gehandhaafd als afzonderlijke metingen van lichamelijke inspanning.

\section{Overige operationalisaties en statistische analyses}

In dit onderzoek zijn overeenkomstig Appels e.a. (1987) de manifestaties van ischemische hartziekten onderscheiden in 'soft events' (angina pectoris, bypass operaties en 'mogelijke' niet fatale infarcten) en 'hard events' ('waarschijnlijke' of 'zekere' niet fatale infarcten en fatale infarcten).

Verder zijn cardiale sterfte (subset van 'hard events') en alle vormen van IHZ ('soft events' en 'hard events') als aparte eindpunten onderscheiden. Ter bepaling van de effecten van lichamelijke inspanning op de $9^{1 / 2}$-jarige incidentie van de onderscheiden ischemische eindpunten zijn logistische regressie-analyses uitgevoerd. Om zuivere effectschattingen te verkrijgen zijn de deelnemers, waarbij ten tijde van de screening al een hartijden werd gesignaleerd, van de analyses uitgesloten. De uitsluitingscriteria waren: angina pectoris zoals vastgesteld met de vragenlijst van Rose en ECG afwijkingen die zeker of mogelijk op een doorgemaakt infarct wijzen, i.c. Minnesotacode 1.1.2.3., IV.1.2.3. of VII.1.

Vanwege het eerste criterium zijn 147 deelnemers en vanwege het tweede criterium 309 deelnemers niet in de follow-up analyses opgenomen. Tabel 4 toont de dataset die ten grondslag ligt aan de follow-up analyses.

Tabel 4. Dataset voor de follow-up analyse van ischemische hartziekten

\begin{tabular}{|l|r|r|}
\hline & $\mathrm{N}$ & \multicolumn{2}{|c|}{ \% } \\
\hline coronaire aandoening tijdens screening & 456 & 14 \\
niet cardiale sterfte & 156 & 5 \\
fataal hartinfarct & 69 & 2 \\
niet fataal hartinfarct (mogelijk) & 25 & 1 \\
niet fataal hartinfarct (wrarschijnlijk/zeker) & 94 & 3 \\
angina/bypass (zonder infarct) & 46 & 1 \\
geed coronair lijden tijdens follow-up & 2251 & 67 \\
uitval & 268 & 7 \\
\hline & 3365 & 100 \\
\hline
\end{tabular}

Behalve de uitsluiting van mannen met een coronair hartlijden tijdens screening zijn apart voor elke analyse van de vier onderscheiden vormen van IHZ 'concurrerende' follow-up eindpunten weggelaten. Voor de operationalisaties van de eindpunten heeft dit de volgende gevolgen. Als non-cases zijn voor ieder ischemisch eindpunt 
steeds de 2251 mannen genomen die, met betrekking tot manifestaties van IHZ, ten tijde van de screening 'gezond' waren en gedurende de $91 / 2$ jaar follow-up 'gezond' bleven; als cases zijn respectievelijk 71 opgetreden 'soft events', 163 opgetreden 'hard events', 69 opgetreden fatale infarcten en alle 234 manifestaties van ischemische hartziekten genomen.

Bij de analyses zijn de expositie-variabelen lichamelijke inspanning in de beroepsuitoefening en totale inspanning als continue variabelen, en lichamelijke inspanning in woon-werk verkeer en in vrije tijd als categorische variabelen in het logistische model opgenomen. De categorische variabelen zijn gedummificeerd waarbij als referentiecategorie telkens de groep met de meeste lichamelijke inspanning is genomen. Dit vanwege de veronderstelling dat bij deze groep de incidentie van ischemische hartziekten het laagst is.

De logistische regressie-analyses zijn apart voor de vier onderscheiden vormen van lichamelijke inspanning uitgevoerd. Allereerst zijn met bivariate regressies de voor leeftijd gecorrigeerde effecten van lichamelijke inspanning op de onderscheiden cardiovasculaire eindpunten vastgesteld. Vervolgens is met multivariate regressie nagegaan of additionele correctie voor diastolische bloeddruk, cholesterolgehalte, Quetelet-index, roken, burgerlijke staat, alcoholconsumptie en sociaal-economische status in andere effectschattingen resulteerde. In de multivariate logistische regressies zijn de cardiovasculaire risicofactoren bloeddruk, cholesterolgehalte en Queteletindex steeds als continue variabelen en de overige (categorische) kenmerken steeds als dummy's gehanteerd. Alle logistische regressie-analyses zijn uitgevoerd met de LR-procedure van het BMDP pakket (Dixon, 1985).

\subsection{RESULTATEN}

In tabel 5 zijn de voor leeftijd gecorrigeerde relatieve risico's van de vier onderscheiden vormen van lichamelijke inspanning op ischemische hartziekten opgenomen. Vijf effecten zijn statistisch significant $(\alpha=0,05$; rechtseenzijdige toetsing). Gecorrigeerd voor leeftijd geldt dat het risico op 'soft events' voor hen die niet fietsend en/of wandelend naar hun werk gaan twee maal zo groot is als voor hen die wel fietsend en/of lopend naar het werk gaan. Voorts zijn bij de 'hard events' twee significante effecten geconstateerd. Hoe geringer de inspanning in het beroep (gem. $=130$, s.d. $=37$ ) en hoe geringer de totale inspanning (gem. $=151$, s.d. $=43$ ) des te groter is de kans op een 'hard event'. Een minder zware lichamelijke inspanning van 10 activiteitseenheden per week gaat bij beide vormen gepaard met een $4 \%$-verhoging van het risico. De bijbehorende 90\% betrouwbaarheidsintervallen (BI's) zijn 1,01-1,07 en 1,01-1,08. Ten aanzien van het eindpunt cardiale sterfte wordt er geen enkel significant effect geconstateerd. Op het eindpunt alle vormen van $\mathrm{IHZ}$ blijkt zowel van de inspanning in het woonwerk verkeer als van de totale inspanning een significant invers 
effect uit te gaan. Mannen die niet fietsend en/of lopend naar het werk gaan hebben een 1,43 keer zo groot risico op alle vormen van IHZ dan hun actievere equivalenten (BI: $1,05-1,95)$. Verder gaat een minder zware totale inspanning van 10 activiteitseenheden per week gepaard met een $4 \%$-verhoging van het risico op alle vormen van $\mathrm{IHZ}$ (BI: 1,01-1,07). Naast de bivariate regressies ('age-adjusted') zijn er ook multivariate logistische regressies uitgevoerd waarbij gecorrigeerd werd voor relevante risicofactoren. De resultaten van de multivariate analyses zijn vrijwel eender aan de zojuist beschreven bivariate resultaten. Zo blijken alle niet significante bivariate effecten na multivariate analyse eveneens niet significant te zijn.

Tabel 5. De voor leeftijd gecorrigeerde relatieve risico's (RR's) en 90\%-betrouwbaarheidsintervalen (90\% B.I.'s) van lichamelijke inspanning ten aanzien van ischemische hartriekten

\begin{tabular}{|c|c|c|c|c|}
\hline Lichamelijke inspanning & $\begin{array}{l}\text { 'Soft events' } \\
\text { RR } \\
\text { (90\% B.I.) }\end{array}$ & $\begin{array}{l}\text { "Hard events" } \\
\text { RR } \\
\text { (90\% B.I.) }\end{array}$ & $\begin{array}{l}\text { Cardiale sterfte } \\
\text { RR ( } 90 \% \text { B.I.) }\end{array}$ & $\begin{array}{l}\text { Alle vormen } \\
\text { IHZ RR }(90 \% \\
\text { BI) }\end{array}$ \\
\hline $\begin{array}{l}\text { Minder zware inspanning }{ }^{1} \text { in } \\
\text { het beroep van } 10 \text { activiteits- } \\
\text { eenheden }\end{array}$ & $\begin{array}{c}1.02 \\
(0.96-1.08)\end{array}$ & $\stackrel{1.04}{(1.01-1.07)}$ & $\begin{array}{c}1.04 \\
(0.98-1.11)\end{array}$ & $\begin{array}{c}1.03 \\
(0.99-1.07)\end{array}$ \\
\hline Noch fietsen noch lopen $\left.{ }^{2}\right)$ & $\begin{array}{c}2.05 \\
(1.10-3.82)\end{array}$ & $\begin{array}{c}1.25 \\
(0.87-1.80)\end{array}$ & $\begin{array}{c}0.93 \\
(0.56-1.54)\end{array}$ & $\begin{array}{c}1.43 \\
(1.05-1.95)\end{array}$ \\
\hline $\begin{array}{l}\text { Vrije tijd } \\
\text { - geen inspanning }\end{array}$ & $\begin{array}{c}1.02 \\
(0.51-2.01)\end{array}$ & $\begin{array}{c}1.12 \\
(0.73-1.72)\end{array}$ & $\begin{array}{c}0.96 \\
(0.32-1.88)\end{array}$ & $\begin{array}{c}1.10 \\
(0.76-1.59)\end{array}$ \\
\hline - geringe inspanning & $\begin{array}{c}0.97 \\
(0.56-1.67)\end{array}$ & $\begin{array}{c}0.95 \\
(0.67-1.35)\end{array}$ & $\begin{array}{c}1.17 \\
(0.70-1.95)\end{array}$ & $\begin{array}{c}0.96 \\
(0.71-1.30)\end{array}$ \\
\hline - matige inspanning & $\begin{array}{c}1.32 \\
(0.77-2.25) \\
\end{array}$ & $\begin{array}{c}0.92 \\
(0.63-1.33) \\
\end{array}$ & $\begin{array}{c}0.76 \\
(0.42-1.38) \\
\end{array}$ & $\begin{array}{c}1.03 \\
(0.75-1.4 I)\end{array}$ \\
\hline $\begin{array}{l}\text { Minder zware totale inspan- } \\
\text { ning }{ }^{1 /} \text { van } 10 \text { activiteits-een- } \\
\text { heden }\end{array}$ & $\begin{array}{c}1.02 \\
(0.97-1.09)\end{array}$ & $\begin{array}{c}1.04 \\
(1.01-1.08)\end{array}$ & $\begin{array}{c}1.04 \\
(0.98-1.10)\end{array}$ & $\begin{array}{c}1.04 \\
(1.01-1.07)\end{array}$ \\
\hline
\end{tabular}

$1)=\quad$ De relatieve risico's zijn zodanig berekend dat de ze de toe- of afname van bet risico weergeven voor een lagere inspanning van 10 activiteitseenheden per week

2) $=$ De gehanteerde referentiecategorie is fietsend dan wel lopend naar werk

$3)=$ De gehanteerde referentiecategorie is veel inspanning in de vrije tijd

Met betrekking tot deze effecten wordt vanwege de grote overeenkomst verwezen naar de bivariate punt- en intervalschattingen. De significante effecten worden wel kort aan de orde gesteld. Zo is het relatieve risico (RR) van woon-werk verkeer op 'soft events' in de multivariate situatie 2,06 (BI: 1,10-3,84). Deze uitkomst is praktisch 
gelijk aan die in de bivariate situatie. De effecten van inspanning in beroep en totale inspanning op 'hard events' zijn in de multivariate situatie iets groter: de relatieve risico's zijn beide 1,05 (BI's: 1,01-1,09) bij een minder zware lichamelijke inspanning van tien activiteitseenheden per week. Het in de bivariate situatie geconstateerde significante effect van woon-werk verkeer op alle vormen van IHZ is feitelijk het enige dat in de multivariate situatie niet in de pas blijft. Na correctie voor de andere risicofactoren is het effect geslonken tot 1,34 (was 1,43). Hoewel de afname in absolute termen minimaal is, is dit gecorrigeerde effect niet meer significant (BI: 0,98-1,84). Het (multivariate) effect van totale inspanning op alle vormen van $\mathrm{IHZ}(\mathrm{RR}=1,04 ; \mathrm{BI}$ : $1,01-1,08)$ correspondeert daarentegen weer volledig met de bivariate bevinding.

Om iets te kunnen zeggen over het aandeel ischemische aandoeningen dat aan de verminderde lichamelijke activiteit zou kunnen worden toegeschreven, zijn, voor voomoemde significante situaties, populatie attributieve risicopercentages berekend. Het populatie attributieve risicopercentage van de expositievariabele is het makkelijkst met behulp van de relatieve risico's van een (beperkte) groepsindeling van deze variabele te berekenen (Kleinbaum e.a. 1982). De multivariate analyses waarbij een inspanningsindex is gehanteerd, zijn daarom nog eens herhaald met kwartielgroepindelingen van de index. Als referentiegroep is daarbij steeds de groep met de hoogste lichamelijke inspanning (4e kwartielgroep) genomen. Multivariate analyse op 'hard events' leverde voor de $1 \mathrm{e}, 2 \mathrm{e}$ en $3 \mathrm{e}$ kwartielgroep van beroepsinspanning de volgende $R R$ 's en $90 \%$ betrouwbaarheidintervallen: $1,45(1,01-2,08), 1,38(0,92-2,07)$ en 1,33 $(0,88-1,99)$. Voor de kwartielgroepen van totale inspanning zijn de overeenkomstige waarden $1,50(1,02-2,20), 1,35(0,91-2,02)$ en $1,32(0,90-2,01)$. De populatie attributieve risicopercentages van beroepsinspanning en totale inspanning zijn respectievelijk 22 en $23 \%$. Ten aanzien van het eindpunt alle vormen van $\mathrm{IHZ}$ zijn de waarden voor totale inspanning $1,48(1,07-2,04), 1,32(0,95-1,84)$ en $1,20(0,86-1,68)$. Het bijbehorende populatie attributieve risico is $20 \%$. Ten slotte bedraagt het populatie attributieve risicopercentage van noch lopend noch fietsend naar het werk gaan op 'soft events' $46 \%$.

\subsection{DISCUSSIE}

Uit de analyses kwam naar voren dat minder zware lichamelijke inspanning in het beroep en minder zware totale inspanning gepaard gaan met een verhoogd risico op een al dan niet fataal hartinfarct. Op de subset cardiale sterfte lijken overeenkomstige effecten van toepassing te zijn. Voorts geldt voor de totale index dat minder zware inspanning een verhoogd risico op alle vormen van IHZ tot gevolg heeft. Voor het kenmerk lichamelijke inspanning in het beroep suggereren de analyseresultaten een overeenkomstig effect. De effecten van inspanning in het beroep en de samenvattende index verschillen in hun voorspellende betekenis slechts weinig van elkaar. Dit is 
vooral een gevolg van de grote samenhang tussen beide variabelen. In beginsel geldt dat de effecten van inspanning in het beroep en de totale inspanning op de genoemde vormen van ischemische hartziekten overeenstemmen met de in de inleiding aangehaalde studies.

Niet in overeenstemming met andere studies is de KRIS-bevinding dat lichamelijke inspanning in de vrije tijd geen samenhang vertoont met de onderscheiden vormen van ischemische hartziekten. Hoewel deze studies veelal het sporten als belangrijkste vrijetijdsactiveit eruit lichten (Lepper e.a. 1963, Paffenbarger e.a. 1978, Chave e.a. 1978) worden ook bij globalere operationalisaties van de vrijetijdsinspanning significante effecten gevonden (Salonen e.a. 1982, Salonen e.a. 1988). Dat een dergelijke significante inverse associatie niet door de KRIS-gegevens wordt bevestigd, heeft mogelijk te maken met het gebruik van een minder valide meetinstrument. Bij de bespreking van mogelijke meetfouten wordt hierop teruggekomen.

Opmerkelijk is de KRIS-bevinding dat mannen die noch fietsend noch lopend naar hun werk gaan een 2,06 maal zo groot risico (BI : 1,10-3,84) op 'soft events' hebben als mannen die zich fietsend en/of lopend naar hun werk begeven. Dit resultaat staat enigszins op gespannen voet met het in de inleiding gesignaleerde gebrek aan empirisch bewijs voor een inverse relatie van lichamelijke activiteit op angina pectoris. Aan de andere kant moet worden aangetekend dat lichamelijke inspanning in het woonwerk verkeer feitelijk een weinig gemaakt onderscheid is. Het zich per fiets verplaatsen is een typisch Nederlands gebruik. Deze activiteitencategorie is in andere landen nauwelijks van toepassing en wordt daar dan ook niet specifiek gemeten. Het gesignaleerde effect moet wellicht als een typisch Nederlandse bevinding worden beschouwd.

Voorts bleek uit de analyses dat de voor leeftijd gecorrigeerde relatieve risico's nauwelijks veranderen wanneer additioneel voor andere cardiovasculaire risicofactoren wordt gecorrigeerd. Dit betekent dat de gehanteerde risicofactoren geen 'confounders' zijn van de onderhavige beinvloedingsrelatie. Dit resultaat komt overeen met de bevindingen van elders (Salonen e.a. 1988, Leon e.a. 1987, Slattery e.a., 1989). Om een indruk te krijgen van de relatieve bijdrage van lichamelijke inactiviteit aan ischemische hartziekten werden populatie attributieve risicopercentages berekend. Zo bedroeg het populatie attributieve risicopercentage van lage beroepsinspanning (de drie laagste kwartielgroepen) op 'hard events' $22 \%$. Dit betekent dat gedurende de $91 / 2$-jarige follow-up bij constanthouding van alle overige risicofactoren bij 36 werkende mannen in de leeftijd van 45-59 jaar $(22 * 163 / 100)$ een hartinfarct ten gevolge van lage lichamelijke inspanning in het beroep voorkomen had kunnen worden. Wat betreft de drie laagste kwartielgroepen van totale inspanning geldt dat $37(23 * 163 / 100)$ hartinfarcten en 46 ischemische hartziekten (alle vormen: 20*234/100) vermeden hadden kunnen worden. Verder zouden, in geval zich alle mannen lopend en/of fietsend naar hun werk hadden begeven, 33 'soft events' $\left(46^{*} 71 / 100\right)$ mogelijk niet zijn opgetreden. Deze aantallen wijzen op een substantiële bijdrage van lichamelijke inactiviteit aan de omvang van ischemische hartziekten. Ter illustratie: het aandeel hartinfarcten dat 
voortkomt uit minder zware inspanning in het beroep en minder zware totale inspanning is bijna de helft van het aandeel dat aan roken (53\%) moet worden toegeschreven.

Bij de berekening van de populatie attributieve risicopercentages zijn de continue inspanningsvariabelen in kwartielgroepen ingedeeld. De daarbij vastgestelde relatieve risico's bleken in volgorde van weinig inspanning naar veel inspanning alle te dalen. Deze bevindingen bevestigen de door ons, in navolging van ondermeer Berlin en Colditz (1990), veronderstelde omgekeerde 'dose response' relatie tussen lichamelijke inspanning en ischemische hartziekten.

Het onderzoek naar de relatie tussen lichamelijke activiteit en ischemische hartziekten staat en valt met de kwaliteit van de metingen van zowel de expositie- als de doelvariabele. De doorslaggevende rol van de meetvaliditeit vindt zijn oorsprong in de empirisch zwakke samenhang tussen beide kenmerken. Misclassificatie van de cardiale eindpunten en misclassificatie in de onderscheiden vormen van lichamelijke inspanning leiden dan al snel tot betekenisvolle vertekening in de effectschatting. Bij de validiteit van de KRIS-metingen moeten een aantal kanttekeningen worden geplaatst. Een belangrijke tekortkoming van de KRIS-studie is dat van de overleden personen, behoudens de screening-gegevens, alleen de doodsoorzaken bekend zijn. Dit betekent dat onbekend is wie na screening en voorafgaand aan zijn dood, angina pectoris of een niet-fataal infarct heeft gehad, of een bypass operatie heeft ondergaan. Met andere woorden ten aanzien van de eindpunten 'soft events', 'hard events' en alle vormen van IHZ heeft zich wellicht enige misclassificatie voorgedaan. Daar de 'fout negatieven' waarschijnlijk onafhankelijk van de expositievariabelen zijn voortgekomen is er mogelijk sprake van onderschatting van de betrokken relatieve risico's.

Ten aanzien van het eindpunt 'soft events' en dus ook ten aanzien van alle vormen van $\mathrm{IHZ}$ is naast non-differentiële misclassificatie ook differentiële misclassificatie opgetreden. Angina pectoris wordt immers veelal pas opgemerkt als de betrokken persoon een verhoogde lichamelijke inspanning levert. Pas dan treden hartklachten op en wordt een arts geconsulteerd. Voor de $91 / 2$-jarige KRIS follow-up betekent dit dat de incidentie van angina pectoris bij personen met verminderde lichamelijke activiteit kan worden onderschat. Dit heeft tevens tot gevolg dat de bijbehorende relatieve risico's onderschattingen kunnen zijn. Bijgevolg kan worden geconstateerd dat met betrekking tot 'soft events' en alle vormen van $\mathrm{IHZ}$ sprake kan zijn van een op twee manieren veroorzaakte onderschatting van het relatieve risico.

Een ander nadeel van de KRIS-studie is dat er geen herhaalde metingen hebben plaatsgevonden. Dit betekent dat in de tijd geen veranderingen in lichamelijke inspanning kunnen worden waargenomen. Het lijkt onwaarschijnlijk dat de lichamelijke inspanning ten tijde van screening (1972-1974) gedurende $9^{1 / 2}$ jaar follow-up niet aan veranderingen onderhevig is. Het ligt bijvoorbeeld voor de hand dat de oudere werkende mannen die ujdens de follow-up met pensioen gaan uiteindelijk aanzienlijk minder lichamelijke inspanning verrichten dan ten tijde van hun actieve beroepsuitoefening. Dit wellicht in tegenstelling tot de jongere mannen die gedurende de follow-up hun 
beroep blijven uitoefenen. Ook kan men zich afvragen of de lichamelijke inspanning ten tijde van screening voldoende indicatief is voor de in voorgaande perioden verrichte activiteiten. Een niet denkbeeldig gevaar is dat de lichamelijke inspanning mogelijk de resultante is van een in de voorafgaande periode door de gezondheid geïndiceerd selectieproces. Met andere woorden niet de lichamelijke inspanning bepaalt de gezondheid maar de gezondheid is bepalend voor de mate van lichamelijke activiteit. Problematisch van de zojuist geschetste potentiële knelpunten is dat nauwelijks te zeggen valt op welke wijze en in welke mate ze van invloed zijn op de uiteindelijke effectschatting. Samenvattend kan worden gesteld dat het niet meten van verandering gedurende de follow-up een beperking is. Het gevaar van een mogelijke causale tegenstrijdigheid daarentegen wordt wellicht enigszins afgezwakt doordat in de logistische regressie-analyses al diegenen zijn uitgesloten die ten tijde van de screening aan een hartkwaal leden.

Een bijkomend probleem met betrekking tot de meting van lichamelijke inspanning is het ontbreken van een gouden standaard voor deze factor. Er bestaan geen gevalideerde vragenlijsten voor de meting van totale lichamelijke inspanning of van lichamelijke inspanning op het werk en in de vrije tijd. Het wekt dan ook geen verbazing dat ten aanzien van eenzelfde type lichamelijke inspanning andere meetinstrumenten andere onderzoeksresultaten opleveren. De met resultaten uit andere studies, divergerende KRIS-bevinding dat lichamelijke inspanning in de vrije tijd geen predictieve waarde heeft op de vier onderscheiden vormen ischemische aandoeningen, is mogelijk toe te schrijven aan het gebruik van een ander, wellicht minder valide, meetinstrument. Het lijkt derhalve zinvol deze bevinding terug te koppelen aan de inhoudelijke reikwijdte van de vragen die aan het gebruikte meetinstrument ten grondslag liggen. Dit laat zien dat de meting van lichamelijke inspanning in de vrije tijd volledig gebaseerd is op het aantal uren dat men wandelt en op het aantal uren dat men matige of zware activiteit verricht. Deze door de samensteller van de vragenlijst (Reiff e.a. 1964) niet beargumenteerde dichotomie is enigszins bevreemdend. Waarom wordt wandelen wel apart genoemd en lichamelijk intensievere verrichtingen zoals sporten en klussen niet? Was wandelen in Anglo-saksische landen aanvang jaren zestig misschien de meest bedreven vrijetijdsinspanning? Begin jaren negentig zijn deze vragen moeilijk te beantwoorden. Wat wel duidelijk naar voren komt is dat met uitzondering van het wandelen alle vrijetijdsactiviteiten in de vragen naar matige of zware activiteiten ('s winters en 's zomers) zijn opgenomen. Besloten is daarom om met een samenvoeging van beide items, post-hoc, aparte analyses uit te voeren. Multivariate logistische regressie-analyse openbaarde dat zij die 's winters en 's zomers geen matige of zware activiteiten verrichten een 1,58 maal zo groot cardiaal sterfterisico hebben dan zij die per week 1 uur of meer dergelijke activiteiten verrichten (BI: 1,03-2,98). Ten aanzien van de andere eindpunten werden er geen significante effecten waargenomen. Deze resultaten suggereren dat ook in Nederland de vrijetijdsinspanning gepaard gaat met een verlaagd risico op ischemische hartziekten. 
Samenvattend geldt dat de KRIS-studie een aantal harde en een aantal minder harde 'bewijzen' levert voor de inverse relatie tussen lichamelijke inspanning en ischemische hartziekten. Bij de validiteit van de metingen van lichamelijke inspanning kunnen evenwel vraagtekens worden geplaatst. Verder heeft de KRIS-studie als nadeel dat de resultaten gebaseerd zijn op gegevens uit de jaren zeventig voor een specifieke leeftijdsgroep van mannelijke inwoners van Rotterdam. Ondanks deze beperkingen moet worden opgemerkt dat de resultaten in hoge mate aansluiten bij het bestaande epidemiologische kennisniveau. Deze convergentie maakt het waarschijnlijk dat ook op de huidige (gehele) Nederlandse bevolking een dergelijke inverse relatie van toepassing is. De berekende populatie attributieve risicopercentages suggereren dat van beleidswege meer aandacht zou moeten uitgaan naar maatregelen om de lichamelijke inspanning te bevorderen. Zo is het verhoogde risico dat voortkomt uit lage lichamelijke inspanning in het beroep feitelijk een pleidooi voor het opzetten van campagnes die gericht zijn op het stimuleren van beweging op de werkplek. Bevordering van het fietsen en het lopen in het woon-werk verkeer zou een volgend punt op de beleidsagenda kunnen zijn.

\subsection{ABSTRACT}

The incidence and potential risk factors of ischemic heart disease were assessed in 3365 Rotterdam males, aged 45-59 years, participating in the Dutch part of the Kaunas Rotterdam Intervention Study (KRIS). Starting from the period between 1972 and 1974 the males were followed for approximately $91 / 2$ years. This paper reports about the association between physical activity and ischemic heart diseases (IHD) as observed in the KRIS follow-up study. Physical activity is measured in four ways: activity in occupation (index), activity in leisure time (none, little, moderate, much), going to work by bicycle and/or on foot (no, yes) and total activity (index). Less heavier occupational and total physical activity of 10 index-values both correspond to a $5 \%$ higher risk of a non-fatal or fatal myocardial infarction. For both indexes the $90 \%$ confidence interval (CI) lies between 1.01 and 1.09. Less heavier total physical activity of 10 index-values also corresponds to a $4 \%$ higher risk of all ischemic events $(90 \%$ $\mathrm{CI}: 1.01-1.08)$. Furthermore not going to work by bicycle and/or on foot is significantly related to a higher risk of angina pectoris or bypass operations $(\mathrm{RR}=2.06 ; 90 \% \mathrm{CI}$ : 1.10-3.84). All the mentioned effects are adjusted for relevant cardiovascular riskfactors. The KRIS-results support the notion of an inverse relation between physical activity and ischemic heart diseases. 


\section{NOTEN IN DE TEKST}

1) Voorbeeld.

De berekening van de activiteitseenheden per week van iemand die per dag 6 uren staand werk en 2 uren tilwerk verricht, in het kader van het woon-werk verkeer 20 minuten fietst en alleen 's zomers 3 uren per week matige of zware activiteiten verricht (zie tevens conversieschema, tabel 2) : tijdseenheid conversie activiteitswaarde eenheid

- inspanning in beroep

\begin{tabular}{|c|c|c|c|c|c|c|}
\hline staand werk & 6 & * & 5 & * & 3 & $=$ \\
\hline tilwerk & 2 & * & 5 & * & 5 & $=$ \\
\hline
\end{tabular}

- inspanning in woon-werk verkeer $\quad 20$

$5 / 60 * 4 \quad=\quad 6,7$

- inspanning in vrije tijd

$3 \quad * \quad 1 / 2 \quad * \quad 5 \quad=7,5$

Wekelijks totaal van activiteitseenheden $=154,7$

\subsection{LITERATUUR}

Appels A, F Otten, P Mulder \& F Sturmans, De KRIS follow-up study I. Methoden van dataverzameling. Tijdschrift voor Sociale Gezondheidszorg 66 (1988) 18-21.

Appels A, P Mulder, M van 't Hof, CD Jenkins, J van Houtem \& F Tan, A prospective study of the Jenkins Activity Survey as a risk indicator for coronary heart disease in the Netherlands. Joumal of Chronic Diseases 40 (1987) 959-965.

Berlin JA \& GA Colditz, A meta-analysis of physical activity in the prevention of coronary heart disease. American Joumal of Epidemiology 132 (1990) 612-628.

Brand RJ, RS Paffenbarger, RI Sholtz \& JB Kampert, Work activity and fatal heart attack studied by multiple logistic risk analysis. American Joumal of Epidemiology 110 (1979) 52-62.

Brunner D, G Manelis, M Modan \& S Levin, Physical activity at work and the incidence of myocardial infarction, angina pectoris, and death due to ischemic heart disease. An epidemiological study in Israeli collective settlements (kibbutzim). Journal of Chronic Diseases 27 (1974) 217-233. 
Chave SPW, JN Morris, S Moss \& AM Semmence, Vigorous exercise inleisure time and the death rate: a study of male civil servants. Joumal of Epidemiology and Community Health 32 (1978) 239-243.

Dixon WJ (eds), BMDP Statistical Software. University of California Press, Los Angeles 1985 .

Garcia-Palmieri MR, P Costas, M Cruz-vidal, PD Sorlie \& RI Havlik, Increased physical activity: A protective factor against heart attacks in Puerto Rico. The American Joumal of Cardiology 50 (1982) 749-755.

Glasunov IS, JE Dowd, A Baubiniene, V Grabauskas, F Sturmans \& JH Schuurman (eds), The Kaunas Rotterdam Intervention Study. Elsevier/North Holland, Amsterdam 1981.

Kannel WB \& P Sorlie, Some health benefits of physical activity. The Framingham Study. Archives of Internal Medicine 139 (1979) 857-861.

Kannel WB, P Wilson \& SN Blair, Epidemiological assessment of the role of physical activity and fitness in development of cardiovascular disease. American Hear Joumal 109, 4, (1985) 876-885.

Keys A, Seven countries. A multivariate analysis of death and coronary heart disease. Harvard University Press, Cambridge (Massachusetts) 1980.

Kleinbaum D, L Kupper \& H Morgenstern, Epidemiologic research: principles and quantitative methods. Lifetime Leaming Publications, Belmont/ Califomia 1982.

Leon AS, J Connett \& DR Jacobs, Leisure time physical activity levels and risk of coronary heart disease and death: the Multiple Risk Factor Intervention Trial. JAMA 258 (1987) 2388-2395.

Lepper PO \& WH Phelan, A longitudinal study of coronary heart disease. Circulation 28 (1963) 20-31.

Magnus K, A Matroos \& J Strackee, Walking, cycling, or gardening, with or without seasonal interruption, in relation to coronary events. American Joumal of Epidemiology 110 (1979) 724-733.

Morris JN, JA Heady, PAB Raffle, CG Roberts \& JW Parks, Coronary heart disease and physical activity of work. Lancet 2 (1953) 1053-1057.

Morris JN, JA Heady \& PAB Raffle, Physique of London busmen: Epidemiology of uniforms. Lancet 2 (1956) 569-570. 
Paffenbarger RS, WE Hale, RJ Brand \& RT Hyde, Workenergy level, personal characteristics, and fatal heart attack: a birth-cohort effect. American Joumal of Epidemiology 105 (1977) 200-213.

Paffenbarger RS, AL Wing \& RT Hyde, Physical activity as an index of heart attack in college alumni. American Journal of Epidemiology 108 (1978) 161-175.

Paffenbarger RS \& RT Hyde, Exercise in the prevention of coronary heart disease. Preventive Medicine 13 (1984) 3-22.

Powell KE, PD Thompson, CJ Caspersen \& JS Kendrick, Physical activity and the incidence of coronary heart disease. Annual Review of Public Health 8 (1987) 253-287.

Reiff GG, HJ Montoye, RD Remington, JA Napier, HL Metzner \& FH Epstein, Assessment of physical activity by questionnaire and interview. In: Karvonen MJ en Barry (eds.). Physical activity and the heart. Proceedings of a Symposium, Helsinki. Charles C. Thomas, Springfield (Illinois) USA 1964, 336-371.

Salonen JT, P Puska \& J Tuomilehto, Physical activity and risk of myocardial infarction, cerebral stroke and death: a longitudinal study in Eastern Finland. American Joumal of Epidemiology 115 (1982) 526-537.

Salonen JT, JS Slater, J Tuomilehto \& R Rauramaa, Leisure time and occupational physical activity: risk of death from ischemic heart disease. American Joumal of Epidemiology 127 (1988) 87-94.

Slattery ML, DR Jacobs \& MZ Nichaman, Leisure time physical activity and coronary heart disease death: the US Railroad Study. Circulation 79 (1989) 304-311.

Taylor HL, E Kelpetar \& A Keys, Death rates among physically active and sedentary employees of the railroad industry. American Journal of Public Health 52 (1962) 1697-1707.

Taylor HL, H Blackbum, A Keys, RW Parlin, C Vasquez \& T Puchner, IV Five-year follow-up of employees of selected railroad companies. Circulation 41, Suppl.1, (1970) 20-39. 



\section{HOOFDSTUK 8 \\ Nabeschouwing}

\subsection{INLEIDING}

In deze studie is verslag gedaan van het prospectieve KRIS-onderzoek naar de effecten van psycho-sociale kenmerken op ischemische hart- en vaatziekten (IHZ) en diverse oorzaken van sterfte in Nederland. Het accent ligt daarbij vooral op de relaties met IHZ. Prospectief onderzoek over deze thematiek heeft in Nederland tot dusver slechts op beperkte schaal plaatsgevonden. De KRIS-bevindingen vormen derhalve een belangrijke aanvulling op het bestaande epidemiologische kennisniveau over oorzaken van IHZ in Nederland. In deze nabeschouwing worden de voornaamste bevindingen beknopt weergegeven. Ook wordt ingegaan op de onderlinge vergelijkbaarheid van de diverse effecten.

\subsection{VOORNAAMSTE KRIS-BEVINDINGEN}

In hoofdstuk 1 zijn de resultaten beschreven van een verkennende studie naar de relaties tussen sociaal-economische status enerzijds en opvattingen over gezondheid, cardiovasculaire risicofactoren, IHZ en sterftekansen anderzijds. De sociaal-economische status (SES) is weergegeven door beroep, opleiding, wijk waarin men woont en een samengestelde index, waarin naast deze drie kenmerken ook het vroegere beroep en het beroep van de vader is opgenomen. Tussen SES-groepen blijken verschillen te bestaan met betrekking tot een aantal algemene opvattingen over ziekte en ten aanzien van riskante levensgewoonten. Deze verschillen wijzen alle in de richting van een voor de gezondheid nadelige situatie voor lagere SES-groepen. SES blijkt voorts weinig samenhang te vertonen met de cardiovasculaire risicofactoren: diastolische bloeddruk, cholesterolgehalte en Quetelet-index. Wel zijn er samenhangen waargenomen wssen SES en roken en alcoholconsumptie. Roken en geheelonthouding komen meer voor in de lagere strata en matig alcoholgebruik is meer prevalent in de hogere strata. Van roken en in mindere mate geheelonthouding is bekend dat ze op onafhankelijke wijze het risico op IHZ verhogen (zie daarvoor tevens de hoofdstukken 3 en 4). Uitgaande van de wellicht reële veronderstelling dat SES in de causale keten aan beide gedragsvormen vooraf gaat, kan worden geconcludeerd dat SES op indirecte wijze, namelijk via voomoemde gedragsvormen, oorzakelijk gerelateerd is aan IHZ. Multivariate analyses lieten evenwel zien dat van SES geen onafhankelijk effect uitgaat op IHZ. SES weergegeven door de indicator SES-wijk bleek in de multivariate situatie wel gerelateerd te zijn aan sterfte ten gevolge van kanker en sterfte ten gevolge van alle 
doodsoorzaken. Mannen uit de hoogste SES-wijk hebben minder kans op beide vormen van sterfte. Verder bleek ook het beroepsniveau samen te hangen met totale sterfte. Mannen in het hoogste beroepsniveau hebben een kleinere kans op sterfte dan mannen in de lagere niveau's.

Bij de bevindingen over SES-wijk en beroep moet evenwel een kritische kanttekening worden geplaatst. Zo zijn in de analyses de waarden van het kenmerk SESwijk telkens toegekend aan de afzonderlijke onderzoekspersonen die in de desbetreffende wijk woonachtig zijn. Hierbij is impliciet ervan uitgegaan dat de factor SES-wijk als een zuiver contextueel kenmerk is te beschouwen. Deze gedachtengang is evenwel alleen dan volledig juist als de (individuele) kenmerken, waarop de indeling in SESwijken is gebaseerd, over iedere wijk gelijkelijk verdeeld zijn (homogeniteit van de wijken). Hoewel dit niet kon worden angetrokken, lijkt het waarschijnlijk dat in de onderscheiden wijken slechts tot op zekere hoogte sprake is van een dergelijke homogeniteit. Dit betekent dat de gevonden associaties met SES-wijk feitelijk gezien moeten worden als samenhangen met een mengeling van deels contextuele en deels individuele SES-componenten.

Ook in de vastgestelde relaties tussen beroep en de onderscheiden follow-up eindpunten kan enige onzuiverheid zijn ingeslopen. Het lijkt aannemelijk dat voor een deel van de respondenten het beroep, zoals ten tijde van screening is vastgesteld, gedurende de follow-up veranderd is. Het effect van dergelijke veranderingen op de gevonden relatieve risico's kon evenwel niet worden vastgelegd omdat er gedurende de follow-up geen herhalingsmetingen hebben plaatsgevonden.

In hoofdstuk 2 wordt het effect van burgerlijke staat op cardiale sterfte en totale sterfte beschreven. Alleenstaande mannen en weduwnaars hebben in vergelijking tot gehuwde mannen een verhoogde kans op cardiale sterfte. Voor totale sterfte geldt dat alleen alleenstaande mannen een verhoogd risico hebben. De resultaten kunnen in het kader van een sociale netwerktheorie worden verklaard. Overeenkomstig deze theorie hebben personen met gebrek aan sociale steun ofwel personen die niet zijn ingebed in een hecht verband van sociale relaties verhoogde gezondheidsrisico's. Deze komen voort uit de beperkte communicatiemogelijkheden. In geval van problemen kan dit overmatige stress-ophoping tot gevolg hebben hetgeen op haar beurt weer tot allerhande gezondheidsproblemen kan leiden. Hoewel een eventueel gebrek aan sociale steun alleen gemeten is met burgerlijke staat, zij benadrukt dat dit kenmerk als een belangrijke component van het sociale netwerk is te beschouwen. Belangrijk, omdat burgerlijke staat uitdrukking geeft aan de aan- of afwezigheid van primaire sociale relaties. Je zou kunnen zeggen dat op gehuwde mannen het aloude gezegde 'gedeelde smart is halve smart' van toepassing is. Gehuwde mannen kunnen vaker uiting geven aan hun problemen dan alleenstaanden. Overeenkomstig de theorie gaat dit gepaard met minder stress en daarom met minder gezondheidsproblemen.

In hoofdstuk 3 zijn de schadelijke effecten beschreven van roken op ernstige ischemische hartziekten (fatale en niet-fatale myocardinfarcten), sterfte ten gevolge van 
kanker aan de luchtwegen en totale sterfte. Roken blijkt een onafhankelijke predictor voor alle drie onderscheiden eindpunten te zijn. De rokers van tien of meer sigaretten hebben ruim zeven maal meer kans op sterfie ten gevolge van kanker aan de luchtwegen en twee maal meer kans op ernstige IHZ. Hoewel niet significant, zijn voor de overige onderscheiden groepen rokers de risico's eveneens verhoogd. Dit geldt voor achtereenvolgens voormalige rokers, pijp- of sigarenrokers en personen die 1-9 sigaretten per dag roken. De non-significantie wordt toegeschreven aan de -zeker in vergelijking met elders uitgevoerde epidemiologische studies op dit terrein- relatief kleine aantallen onderzoekspersonen. Desalniettemin komt uit de resultaten duidelijk naar voren dat voorkomen moet worden dat mensen ooit met roken beginnen. Immers ook na het stoppen blijft het risico op ischemische hartziekten, sterfte ten gevolge van kanker aan de luchtwegen en totale sterfte langdurig verhoogd.

De relaties tussen alcoholconsumptie en $\mathrm{IHZ}$ en totale sterfte vormen het onderwerp van studie in hoofdstuk 4 . IHZ is daarbij onderscheiden in cardiale sterfte en ernstige ischemische aandoeningen (fatale en niet fatale hartinfarcten). Internationaal onderzoek heeft uitgewezen dat alcoholgebruik U-vormig gerelateerd is aan beide eindpunten. Matig drinken gaat, in tegenstelling tot nooit drinken en excessief drinken, gepaard met een lager risico op sterfte en IHZ. Deze U-vormige relatie wordt door de KRIS-gegevens niet bevestigd. Wel suggereren de resultaten dat in vergelijking met de nooit drinkers de matige en zware drinkers een lager risico op $\mathrm{BHZ}$ en totale sterfte hebben. Dit zou betekenen dat van alcoholconsumptie ongeacht de drinkfrequentie en -hoeveelheid een in cardiovasculair opzicht beschermend effect uitgaat. Hierbij moet wel worden aangetekend dat het niet onwaarschijnlijk is dat de nooit- drinkers een, op grond van een bepaalde medische of psycho-sociale karakteristiek, uitzonderlijke groep vormen. Vanwege het ontbreken van relevante gegevens kon deze optie niet worden onderzocht. Een volgende beperking van de alcoholstudie betreft de verouderde, globale meting van alcoholconsumptie. In de KRIS zijn weliswaar allerhande vragen naar alcoholgebruik gesteld, maar is verzuimd naar de exacte hoeveelheid te vragen. Replicaties van en vergelijkingen met de in het epidemiologisch onderzoek zo gebruikelijke intervalmaten van alcoholconsumptie (bijvoorbeeld het wekelijkse gemiddelde van het aantal genuttigde glazen alcoholhoudende drank) konden derhalve niet worden doorgevoerd. Een verder beperkend punt is dat in de follow-up geen herhalingsmetingen van alcoholconsumptie hebben plaatsgevonden. Met eventueel opgetreden veranderingen in het drinkgedrag kon zodoende geen rekening worden gehouden.

In hoofdstuk 5 wordt ingegaan op de vraag of stress, gemeten door de 'Reeder stress scale', een onafhankelijke oorzaak is van cardiale sterfte, cardiale morbiditeit (niet-fatale myocardinfarcten) en totale sterfte. De stress-schaal blijkt op geen van deze eindpunten een predictieve waarde te hebben. Psychometrische overwegingen wijzen evenwel uit dat de 'Reeder stress scale' geen valide stress-meting geeft. De schaal geeft veelmeer uitdrukking aan een vage, algemene geneigdheid tot klagen en moet daarom worden beschouwd als een meting van neuroticisme. De 'Reeder stress scale' 
omvat zeven items waarvan er één verwijst naar ongewone vermoeidheid. Dit item 'aan het eind van de dag ben ik lichamelijk en geestelijk volledig uitgeput' is in afzonderlijke analyses aan cardiale mortaliteit en morbiditeit gerelateerd. Hoewel het hier een a posteriori benadering betreft, tonen de resultaten dat gedurende de eerste dertig maanden van de follow-up gevoelens van uitputting sterk voorspellend zijn voor cardiale sterfte. Met cardiale morbiditeit blijkt er geen verband te zijn.

In hoofstuk 6 wordt beschreven hoe familiale belasting met ischemische aandoeningen bij naaste familieleden van invloed is op het ontstaan van IHZ. Mannen die zijn belast door de aanwezigheid van een myocardinfarct bij naaste familieleden hebben een hogere bloeddruk, een hoger cholesterolgehalte en een verhoogde kans op diverse vormen van IHZ. Op mannen die zijn belast door de aanwezigheid van een hersenbloeding bij naaste familieleden is deels hetzelfde van toepassing. In beide gevallen geldt dat mannen die zowel via een der ouders als via een der broers of zussen zijn belast, het grootste risico op $\mathrm{IHZ}$ hebben. Het risico op $\mathrm{IHZ}$ is kleiner als de belasting alleen via broers of zussen verloopt. Mannen met alleen een parentale voorgeschiedenis hebben daarentegen nauwelijks een verhoogd risico. Elders uitgevoerd onderzoek heeft aangetoond dat parentale belasting met een myocardinfarct vooral een voorspellende waarde heeft als het infarct bij een of beide ouders voor het vijftigste levensjaar heeft plaatsgevonden. Dit kon niet worden nagetrokken daar in de KRIS-studie geen gegevens over de bijbehorende leeftijd zijn opgenomen.

In hoofdstuk 7 staat de onderzoeksvraag centraal of lichamelijke inspanning een protectieve werking heeft op IHZ. Lichamelijke inspanning is daarbij onderscheiden in respectievelijk beroepsinspanning, inspanning in het woon-werk verkeer, inspanning in de vrije tijd en totale inspanning. Lichamelijke inspanning in het beroep en totale inspanning blijken op onafhankelijke wijze gerelateerd te zijn aan diverse vormen van IHZ. Daarbij is sprake van een omgekeerde 'dose-response' relatie: hoe hoger de inspanning, des te kleiner het risico op IHZ. Verder geldt dat lichamelijke inspanning in het woon-werk verkeer, gemeten als lopend en/of fietsend naar het werk gaan, gepaard gaat met een verlaagd risico op angina pectoris en/of 'bypass'-operaties. Daar het zich per fiets verplaatsen een typisch Nederlands gebruik is, moet dit effect grotendeels als een typisch Nederlandse bevinding worden beschouwd.

\subsection{PSYCHO-SOCIALE EN SOMATISCHE EFFECTEN ONDERLING VERGELEKEN}

De effecten van de psycho-sociale en 'somatische' kenmerken zijn in het voorgaande telkenmale beschreven in termen van relatieve risico's. Deze voor 'confounding' gecorrigeerde ratio's van incidentie zijn niet exact bepaald maar benaderd door ofwel 'odds'-ratio's (met logistische regressie) ofwel 'hazard rate'-ratio's (met Cox'-regressie). Het relatieve risico is te beschouwen als een indicatie voor de sterkte van het 
desbetreffende psycho-sociale of somatische effect op ischemische hartziekten. Een nadeel van deze maat is dat deze op generlei wijze rekening houdt met het aantal geëxponeerden in de desbetreffende expositiecategorie(ën). Voor een bepaalde risico-xpositie kan dan wel een groot relatief risico worden waargenomen maar als slechts een klein aantal personen aan deze schadelijke factor is blootgesteld, is de omvang van het desbetreffende gezondheidsprobleem relatief marginaal. Ter illustratie: het relatieve risico op longkanker van degenen die op hun werk aan asbeststof zijn blootgesteld is aanzienlijk groter dan dat van zware rokers. Omdat evenwel het aantal rokers in een samenleving vele malen groter is dan het aantal personen dat op het werk aan asbeststof is blootgesteld, is de omvang van het gezondheidsprobleem voortkomend uit roken groter dan dat uit asbest-expositie.

Een epidemiologische effectmaat die rekening houdt met zowel de sterkte van het effect als het aantal geëxponeerden is het populatie attributieve risicopercentage (Cole en MacMahon 1971), ook wel genoemd attributief risico (Levin 1953) of etiologische fractie ${ }^{1)}$ (Miettinen 1974, Kleinbaum 1985). De etiologische fractie geeft uitdrukking aan het percentage ziektegevallen dat niet zou zijn opgetreden als de desbetreffende risicofactor in de populatie niet van toepassing zou zijn. $\mathrm{Z}_{\mathrm{ij}}$ toont dus feitelijk de verwachte proportie ziektereductie in geval van een optimale preventie. Optimaal staat hier voor een volledige verschuiving van de verdeling naar de laagste risicocategorie (doorgaans de referentiecategorie) van de desbetreffende risicofactor. Berekening van de etiologische fracties van alle relevante risicofactoren levert inzicht in de relatieve bijdrage van elke factor in het voorkomen van toekomstige ziekten. Vanwege de onderlinge vergelijkbaarheid spelen de attributieve risicopercentages een belangrijke rol in de opzet en evaluatie van preventieve gezondheidsprogramma's. Een attributief risicopercentage kan alleen worden berekend als er sprake is van een positieve relatie tussen de expositie- en de eindpuntvariabele (hoe groter de expositie des te groter het risico). Is er evenwel sprake van een negatieve of protectieve relatie (hoe groter de expositie des te kleiner het risico) dan kan een analoge maat, de zogenoemde preventieve fractie ${ }^{2)}$ (Miettinen, 1974), worden gebruikt. Op haar beurt verwijst de preventieve fractie naar de proportie nieuwe 'cases' die zouden zijn opgetreden als de expositie niet had plaatsgevonden.

Waar bij de hantering en interpretatie van attributieve risicopercentages (en preventieve fracties) rekening mee moet worden gehouden, is dat de som van de relatieve bijdragen van diverse van toepassing zijnde risicofactoren niet aan een bepaalde bovengrens gebonden is. Het totaal van attributieve risicopercentages behorende tot meer risicofactoren overschrijdt donrgaans de $100 \%$ en is feitelijk oneindig. Rothman (1986) schrijft dit toe aan de veelvoud van causale mechanismen waarmee een risicofactor in samenwerking met andere, voor het merendeel onbekende, causale componenten een bepaalde ziekte kan voortbrengen.

In tabel 8.1 staan voor diverse ischemische eindpunten de diverse etiologische en preventieve fracties weergegeven. Conform Appels e.a. (1987) zijn de ischemische 
hartziekten daarbij onderscheiden in 'soft events' (angina pectoris en 'bypass'-operaties) en 'hard events' (niet fatale en fatale myocardinfarcten). Ook zijn cardiale sterfte (fatale myocardinfarcten) en alle vormen van IHZ ('soft events' en 'hard events' samengenomen) als aparte eindpunten onderscheiden. De berekeningen zijn gebaseerd op de gecorrigeerde relatieve risico's zoals verkregen met multipele logistische regressie-analyses. In deze analyses zijn de 'somatische' risicofactoren diastolische bloeddruk, cholesterolgehalte, leeftijd en Quetelet-index in kwartielgroepen ingedeeld. Van de psychosociale kenmerken is steeds hetzelfde groepenonderscheid aangehouden als in voorgaande hoofdstukken. Van de psycho-sociale kenmerken met verschillende operationalisaties is alleen van indicatoren die minimaal aan eén ischemisch eindpunt (significant) zijn gerelateerd, informatie opgenomen. Verder zijn van de kenmerken sociaaleconomische status en lichamelijke inspanning, die protectief zijn gerelateerd aan $\mathrm{IHZ}$, geen preventieve maar etiologische fracties berekend. Dit is gedaan omdat voor deze kenmerken in respectievelijk de hoofdstukken 1 en 7 de relaties met LHZ gespiegeld zijn weergegeven. De groep met de hoogste score (de laagste risicogroep) is in deze hoofdstukken als referentiecategorie genomen. Van het kenmerk alcoholconsumptie zijn wel preventieve fracties berekend. Dit in overeenstemming met de beschrijving van de negatieve relatie tussen alcoholconsumptie en IHZ in hoofdstuk 4. Bij de hieronder volgende globale vergelijking van de etiologische en preventieve fracties is het criterium van statistische significantie enigszins op de achtergrond gehouden. Dit omdat bepaalde bevindingen, ook al zijn ze statistisch minder hard, beleidsmatige relevantie kunnen hebben. Te denken valt daarbij vooral aan die niet-significante kenmerken waarvan voor alle onderscheiden ischemische eindpunten telkenmale relatief grote EF's en PF's zijn waargenomen. Verondersteld wordt dat de 'non-significantie' van deze kenmerken voor een belangrijk deel een gevolg is van te kleine aantallen steekproefpersonen.

Tabel 8.1 laat zien dat de omvang van 'hard events' voor het merendeel moet worden toegeschreven aan roken, verhoogd cholesterolgehalte en verhoogde diastolische bloeddruk. De relatief grootste bijdrage is afkomstig van het roken ( $E F=53,4 \%$ ). Daarnaast leveren ook lichamelijke inactiviteit in het beroep en totale lichamelijke inactiviteit een niet onaanzienlijke bijdrage (EF's van respectievelijk $22,1 \%$ en $20,1 \%$ ). Verder lijkt van het (ooit) nuttigen van alcoholhoudende drank (de afzonderlijke categorieën voormalige drinkers $\mathrm{t} / \mathrm{m}$ drinkers van grote hoeveelheden) een forse preventieve werking uit te gaan. Als niemand ooit alcoholhoudende drank tot zich had genomen, zouden $46,4 \%$ meer 'hard events' zijn opgetreden. De bijdragen van Queteletindex, familiale belasting, lichamelijke inactiviteit in het woon-werk verkeer, geestelijk en lichamelijk uitgeput zijn aan het einde van de dag en Queteletindex zijn alle van minder belang. 
Tabel 8.1 Etiologische fracties KRIS-risicofactoren ta.v. ischemische hartziekten

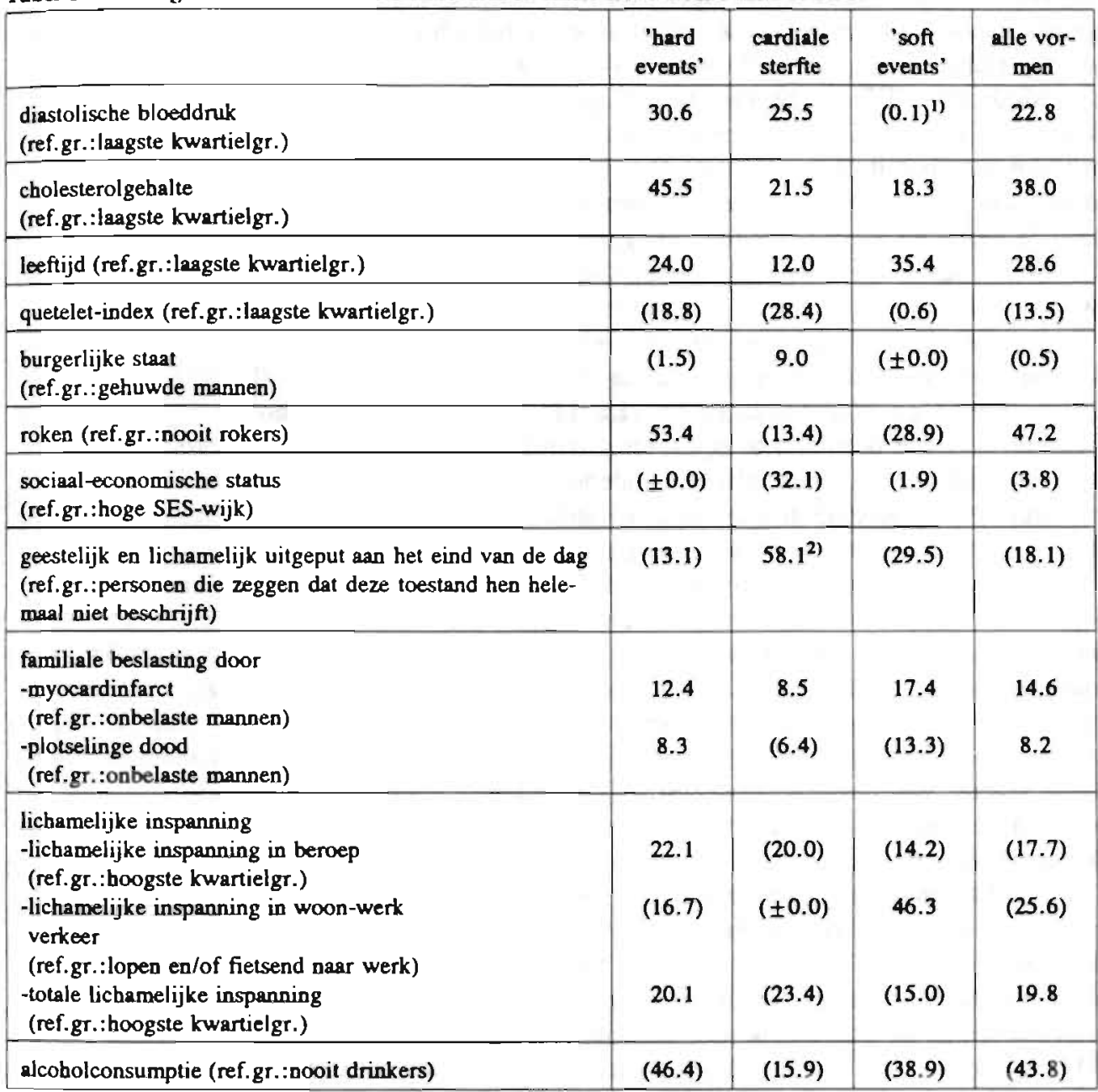

1) = etiologische of preventieve fracties betrekking hebbende op niet significante relatieve risico's zijn tussen haakjes weergegeven.

2) = de hier berekende eliologische fractie heeft alleen betrekking op de exste dertig maanden van de follow-up

De omvang van de cardiale sterfte moet blijkens tabel 8.1 voor een belangrijk deel worden toegeschreven aan de 'somatische' risicofactoren diastolische bloeddruk en cholesterolgehalte (EF's zijn respectievelijk $25,5 \%$ en $21,5 \%$ ). Als alleen de eerste 30 
maanden van de follow-up in ogenschouw worden genomen, dan is de grootste bijdrage afkomstig van het kenmerk geestelijk en lichamelijk uitgeput zijn aan het einde van de dag $(E F=58,1 \%)$. Wordt evenwel de gehele follow-up periode van $91 / 2$ jaar bezien, dan slinkt deze EF tot $12,9 \%$. In belangrijke mate bepalend voor cardiale sterfte zijn verder de kenmerken lichamelijke inactiviteit in het beroep $(E F=20 \%)$ en totale lichamelijke inactiviteit $(E F=23,4 \%)$. Roken levert daarentegen slechts een marginale bijdrage aan de omvang van cardiale sterfte $(E F=13,4 \%)$. Voor burgerlijke staat en familiale belasting geldt hetzelfde. De gevonden hoge bijdragen van (lagere) sociaal-economische status en (hogere) Queteletindex (EF's respectievelijk 32,1\% en 28,4\%) worden vanwege hun eenmalige karakter als toevallige bevindingen beschouwd.

Belangrijke bijdragen aan het ontstaan van 'soft events' zijn afkomstig van de kenmerken lichamelijke inactiviteit in het woon-werk verkeer $(E F=46,3 \%)$, roken $(E F=28,9 \%)$ en cholesterolgehalte $(E F=18,3 \%)$. Ook de alcoholconsumptie lijkt in belangrijke mate bepalend te zijn. Het percentage 'soft events' dat vóorkomen had kunnen worden als iedereen alcoholhoudende drank zou nuttigen bedraagt $38,9 \%$. De resterende etiologische fracties lijken minder beduidend. Ofwel de bijdrage is gering ofwel is er sprake van een toevallige bevinding.

Van alle relatieve bijdragen die in tabel 8.1 zijn weergegeven, spreken de cijfers ten aanzien van het eindpunt alle vormen van $\mathrm{IHZ}$ wellicht de meest klare taal. De tabel laat zien dat vooral roken $(E F=47,2 \%)$, cholesterolgehalte $(E F=38 \%)$ en diastolische bloeddruk $(E F=22,8 \%)$ bijdragen aan alle vormen van IHZ. Verder zijn substantiële bijdragen afkomstig van de onderscheiden vormen van lichamelijke inspanning (variërend van ongeveer 18 tot $26 \%$ ) en van alcoholconsumptie. De hoge preventieve fractie van alcoholconsumptie $(43,8 \%)$ geeft aan dat van het (ooit) drinken van alcoholhoudende drank een forse preventieve werking lijkt uit te gaan. De overige kenmerken spelen nauwelijks een rol in het ontstaan van alle vormen van IHZ.

Samenvattend kan gesteld worden dat van de onderzochte kenmerken vooral roken en cholesterolgehalte en in iets mindere mate diastolische bloeddruk, lichamelijke inactiviteit en geheelonthouding een belangrijke bijdrage leveren aan de omvang van ischemische hartziekten. Verder is er sprake van een belangrijke korte termijn bijdrage van geestelijk en lichamelijk uitgeput zijn aan het einde van de dag aan cardiale sterfte. De bijdragen van Quetelet-index, familiale belasting, sociaal-economische status en burgerlijke staat zijn ofwel toevallig ofwel te klein om een rol van betekenis te spelen.

De hier gepresenteerde resultaten geven aan dat in de bestrijding van ischemische hartziekten vooral rendement te verwachten is van beleidsmaatregelen die zich richten op het beperken van roken en het bevorderen van lichamelijke inspanning. Geen van de onderzochte psychosociale risicofactoren gaf een aanwijzing dat hierop een preventief gezondheidsprogramma zou kunnen worden gebaseerd. Een mogelijke uitzondering hierop is de factor uitputting, die op korte termijn een aanzienlijke bijdrage leverde aan de omvang van cardiale sterfie. 


\section{NOTEN}

1) Het populatie attributieve risico-percentage ofwel de etiologische fractie (EF) is conform Kleinbaum (Kleinbaum e.a., 1982) berekend als:

$$
E F=\frac{\sum p_{i}\left(R R_{i}-1\right)}{\sum p_{i}\left(R R_{i}-1\right)+1}
$$

waarbij $\mathrm{p}_{\mathrm{i}}$ staat voor de proportie geēxponeerden in de desbetreffende categorie van de expositievariabele, en $R_{\mathrm{i}}$ voor het relatieve risico van de desbetreffende categorie met de referentiecategorie (het gemiddelde van alle $\mathrm{RR}_{j}$ 's van de expositievariabele is daarbij telkenmale groter dan 1).

2) De formule voor de preventieve fractie (PF) is volgens Miettinen (Miettinen, 1974):

$$
P F=1-\sum p_{i}\left(R R_{i}\right)
$$

waarbij $\mathrm{p}_{\mathrm{i}}$ staat voor de proportie geëxponeerden in de desbetreffende categorie van de expositievariabele, en $\mathrm{RR}_{\mathrm{i}}$ voor het relatieve risico van de desbetreffende categorie met de referentiecategorie (het gemiddelde van alle $R R_{i}$ 's van de expositievariabele is daarbij telkenmale kleiner dan 1). 


\subsection{LITERATUUR}

Appels A, P Mulder, $M$ van 't Hof, CD Jenkins, J van Houtem \& F Tan. A prospective study of the Jenkins Activity Survey as a risk indicator for coronary heart disease in the Netherlands. Joumal of Chronic Diseases 1987; 40: 959-965.

Cole, P, \& Macmahon, B. Attributable risk percent in case-control studies. British Journal of Preventive Social Medicine 1971; 25: 242-244.

Kleinbaum, DG, LL Kupper \& $\mathrm{H}$ Morgenstern. Epidemiologic research: principles and quantitative methods. Lifetime Learning Publications, Belmont/California 1982.

Levin, ML. The occurrence of lung cancer in man. Acta Unio Internationalis Contra Cancrum; 19: 531-541.

Miettinen, OS. Proportion of disease caused or prevented by a given exposure, trait or intervention. American Joumal of Epidemiology 1974; 99: 325-332.

Rothman, K. Modem Epidemiology. Little, Brown and Company, Boston/Toronto 1986. 


\section{SAMENVATTING}

Hoewel er sprake is van een dalende trend, komt in Nederland nog steeds ongeveer $40 \%$ van de totale sterfte voor rekening van hart- en vaatziekten (HVZ). Een belangrijk deel van de HVZ-sterfte wordt veroorzaakt door ischemische hartziekten (IHZ). Mannen overlijden vaker ten gevolge van IHZ dan vrouwen. In de jaren zeventig werd bij mannen ongeveer $60 \%$ en bij vrouwen ongeveer $45 \%$ van de HVZ-sterfte veroorzaakt door IHZ. In de jaren tachtig daalde dit percentage tot ruim $50 \%$ bij mannen en tot ongeveer $40 \%$ bij vrouwen. Internationaal prospectief onderzoek heeft uitgewezen dat hoge bloeddruk, hoog cholesterolgehalte, overgewicht, roken en leeftijd belangrijke oorzaken van $\mathrm{IHZ}$ zijn. Ook is empirisch aangetoond dat naast het roken de gedragskenmerken geen of buitensporig alcoholgebruik, gebrek aan lichamelijke inspanning en stress het risico op IHZ verhogen. Naast de genoemde schadelijke gedragskenmerken is tevens empirisch aangetoond dat bepaalde omgevingskenmerken zoals het ontbreken van sociale steun, familiale belasting en lage sociaal-economische status het ontstaan van IHZ bevorderen. In Nederland evenwel is nauwelijks prospectief onderzoek verricht naar de effecten van gedrags- en omgevingskenmerken op het ontstaan van IHZ.

Centrale doelstelling van dit proefschrift was te onderzoeken of en in welke mate de zojuist genoemde gedrags- en omgevingskenmerken, kortweg aangeduid met psycho-sociale kenmerken, ook in Nederland van invloed zijn op toekomstige ischemische hart- en vaatziekten. De gegevens zijn ontleend aan de Kaunas Rotterdam Intervention Study (KRIS). In het kader van de KRIS zijn gedurende 1972-1974 3365 Rotterdamse mannen in de leeftijd van 45-60 jaar gescreend op (potentiële) cardiovasculaire risicofactoren. Dit cohort is vervolgens gemiddeld $91 / 2$ jaar gevolgd op de incidentie van ischemische hartziekten en oorzaken van sterfte.

In het onderzoek is doorgaans het onderscheid aangehouden tussen 'soft events' (angina pectoris of 'bypass'-operaties), 'hard events' (niet fatale en fatale myocardinfarcten), cardiale sterfte (fatale myocardinfarcten) en alle vormen van IHZ ('soft events' en 'hard events' samengenomen). Om tot zuivere effectschattingen van de psycho-sociale kenmerken te komen, is in de analyses de invloed van de 'somatische' risicofactoren leefujd, diastolische bloeddruk, cholesterolgehalte en overgewicht (Quetelet-index) steeds constant gehouden. In beginsel is bij deze 'somatische' effecten steeds sprake van een 'dose respons' relatie met $\mathrm{HHZ}$ : hoe hoger de score op de risicofactor des te groter het risico op een ischemische aandoening.

'Hard events' worden mede veroorzaakt door rookgedrag, lichamelijke inactiviteit en familiale belasting. Mannen die dagelijks tien of meer sigaretten roken hebben een ruim twee maal zo groot risico op 'hard events' als mannen die nooit gerookt hebben. Verder suggereren de resultaten dat mannen in de overige rookcategorieën eveneens een verhoogd risico hebben. Het betreft hier achtereenvolgens mannen die 
tien jaar of langer geleden zijn gestopt met roken, mannen die minder dan tien jaar geleden zijn gestopt, de pijp en/of sigarenrokers en de rokers van dagelijks 1-10 sigaretten. Met betrekking tot het kenmerk lichamelijke inspanning geldt dat zowel de inspanning in het beroep als de totale inspanning gerelateerd zijn aan 'hard events'. Voor deze als indexen gemeten activiteiten geldt: hoe geringer de inspanning des te groter het risico op een 'hard event'. Familiale belasting weergegeven door de gerapporteerde aanwezigheid van achtereenvolgens een myocardinfarct en een plotselinge dood bij naaste familieleden gaat eveneens gepaard met een verhoogd risico op 'hard events'. In beide gevallen is het contrast tussen de zowel via ouders als via broers of zussen belaste mannen (dubbel belaste mannen) en de onbelaste mannen verantwoordelijk voor de samenhang. In vergelijking tot niet familiaal belaste mannen hebben mannen die dubbel belast zijn of mannen die alleen via broers of zussen belast zijn met een myocardinfarct een ruim twee maal zo groot risico op 'hard events'. Mannen die dubbel belast zijn met een plotselinge dood bij naaste familieleden hebben een bijna drie maal zo groot risico. Stress zoals gemeten met de 'Reeder stress scale' en het daaruit, naar vitale uitputting verwijzende, afzonderlijk genomen item 'Aan het eind van de dag ben ik lichamelijk en geestelijk uitgeput' hebben geen voorspellende waarde voor 'hard events'. Voor sociaal-economische status gemeten als beroep, opleiding, SES-wijk en een samengestelde index, geldt hetzelfde. Alcoholconsumptie lijkt daarentegen een gezondheidsbevorderende werking te hebben. Bij alle onderscheiden groepen 'drinkers' (lichte drinkers $\mathrm{t} / \mathrm{m}$ zware drinkers) is steeds sprake van een verlaagd risico op 'hard events'. Aanwijzingen voor een eventueel U-vormig verband zoals die uit elders uitgevoerde prospectieve studies zijn voortgekomen, worden door de KRIS-resultaten niet bevestigd.

Cardiale sterfte wordt mede veroorzaakt door de psycho-sociale kenmerken burgerlijke staat en familiale belasting met een myocardinfarct bij naaste familieleden. Alleenstaande mannen en weduwnaars hebben ongeveer een drie maal zo grote kans op een fataal myocardinfarct als gehuwde mannen. Vergeleken met onbelaste mannen lopen dubbel belaste mannen een ruim drie maal zo groot risico op het krijgen van een fataal myocardinfarct. Verder suggereren de resultaten dat lichamelijke inspanning in het beroep en totale inspanning gepaard gaan met een verlaagd risico op cardiale sterfte. Sociaal-economische status en stress zijn niet gerelateerd aan cardiale sterfte. Wat de stress betreft, is evenwel een relativerende opmerking op zijn plaats. Stress zoals gemeten met de 'Reeder stress scale' is niet aan cardiale sterfie gerelateerd. Gevoelens van uitputting aan het einde van de dag zijn in het begin van de follow-up echter wel sterk voorspellend. Gedurende de eerste tien maanden van de follow-up is het risico op cardiale sterfte voor deze uitgeputte mannen bijna negen maal zo groot als voor de niet uitgeputte mannen.

'Soft events' worden mede veroorzaakt door de kenmerken lichamelijke inspanning in het woon-werk verkeer en familiale belasting weergegeven door de gerapporteerde aanwezigheid van een myocardinfarct bij naaste familieleden. Wat de fami- 
liale belasting betreft, geldt dat de via broers of zussen belaste mannen een ruim drie maal zo groot risico op 'soft events' hebben als de niet belaste mannen. Verder hebben mannen die noch fietsend noch lopend naar hun werk gaan een twee maal zo groot risico op 'soft events' als mannen die zich fietsend en/of lopend naar hun werk begeven. Dit effect moet als een typisch Nederlandse bevinding worden beschouwd.

Op alle vormen van IHZ blijken de kenmerken roken, lichamelijke inspanning en familiale belasting van invloed te zijn. De samenhang met familiale belasting geldt voor de gerapporteerde aanwezigheid van een myocardinfarct en van een plotselinge dood bij naaste familieleden. In beide gevallen hebben zowel de via broers of zussen belaste mannen als de dubbel belaste mannen een ruim twee maal zo grote kans op alle vormen van IHZ als de niet belaste mannen. Mannen die tien of meer sigaretten roken, hebben een ruim twee maal zo groot risico op alle vormen van IHZ als mannen die nooit hebben gerookt. Verder geldt dat een hogere (totale) lichamelijke inspanning gepaard gaat met een lager risico op alle vormen van IHZ. Wat betreft de alcoholconsumptie suggereren de resultaten dat mannen die alcoholhoudende drank nuttigen, ongeacht de drinkfrequentie en hoeveelheid, in vergelijking tot de nooit drinkers een lager risico op alle vormen van IHZ hebben. Stress en gevoelens van uitputting aan het einde van de dag zijn niet gerelateerd aan alle vormen van $\mathrm{HHZ}$. Ook voor sociaal-economische status weergegeven door beroep, opleiding, SES-wijk en een samengestelde index zijn geen duidelijke patronen met alle vormen van IHZ te onderkennen. Daar dit ook geldt voor de eindpunten 'soft events', 'hard events' en cardiale sterfie lijkt de conclusie gerechtvaardigd dat sociaal-economische status geen onafhankelijke risicofactor is voor ischemische hartziekten.

In bovenstaande zijn de effecten van de diverse risicofactoren steeds uitgedrukt in termen van relatieve kansverhoudingen. Een relatieve kansverhouding geeft een indicatie van de sterkte van het effect van een bepaalde risicofactor maar geeft geen uitsluitsel over de relatieve bijdrage van die risicofactor in de omvang van het desbetreffende gezondheidsprobleem. Dit omdat geen rekening wordt gehouden met het aantal daadwerkelijk opgetreden hartziekten per onderscheiden groep. Wordt hiermee wel rekening gehouden dan levert dit de volgende globale inzichten. Van alle onderzochte risicofactoren dragen vooral roken en cholesterolgehalte en in iets mindere mate leeftijd, diastolische bloeddruk en lichamelijke inactiviteit bij aan het ontstaan van $\mathrm{IHZ}$. Verder is er sprake van een belangrijke korte termijn bijdrage van het kenmerk geestelijk en lichamelijk uitgeput zijn aan het einde van de dag aan cardiale sterfte. De bijdragen van Quetelet-index, familiale belasting, sociaal-economische status en burgerlijke staat aan de onderscheiden vormen van ischemische hartziekten zijn te verwaarlozen.

De resultaten geven aan dat in de bestrijding van hart- en vaatziekten vooral rendement te verwachten is van beleidsmaatregelen die zich richten op het beperken van roken en het bevorderen van lichamelijke inspanning. Geen van de in de KRISstudie onderzochte psycho-sociale risicofactoren gaf een aanwijzing dat hierop een 
preventief gezondheidsprogramma zou kunnen worden gebaseerd. De enige uitzondering hierop vormt wellicht de factor uitputting, die op korte termijn een aanzienlijke bijdrage leverde aan de omvang van cardiale sterfte.

De KRIS-studie heeft als nadeel dat de resultaten gebaseerd zijn op gegevens uit de jaren zeventig voor een specifieke leeftijdsgroep van mannelijke inwoners van Rotterdam. Dit betekent, strikt genomen, dat de resultaten niet naar de huidige gehele Nederlandse bevolking gegeneraliseerd kunnen worden. Een bijkomend nadeel is dat in de KRIS-studie geen herhalingsmetingen hebben plaatsgevonden. Met mogelijke verstorende effecten voortkomende uit eventueel opgetreden veranderingen in de psycho-sociale kenmerken kon derhalve geen rekening worden gehouden. Toch moet worden opgemerkt dat, uitgezonderd voor sociaal-economische status, de bevindingen van de KRIS-studie in grote lijnen overeenstemmen met de bevindingen uit elders uitgevoerde prospectieve studies. Deze overeenkomst maakt het waarschijnlijk dat de besproken risicofactoren ook op de huidige Nederlandse populatie van toepassing zijn. 


\section{SUMMARY}

Despite a decreasing trend $40 \%$ of mortalities are still caused by cardiovascular diseases in the Netherlands. The major part of cardiovascular mortality originates from ischemic heart diseases (IHD). Compared to women, men are more likely to be struck down by IHD. In the seventies, for instance, IHD contributed to $60 \%$ of the cardiovascular mortality for men and $45 \%$ for women. In the eighties the figures decreased to just over $50 \%$ for men and approximately $40 \%$ for women. International prospective studies revealed that hypertension, high cholesterol levels, obesity, smoking and age are significant causes of IHD. Besides smoking, empirical evidence for greater risk of $\mathrm{IHD}$ is also available for other behavioural characteristics such as none or high alcoholconsumption, physical inactivity and stress. Furthermore evidence of greater risk of IHZ exists for environmental characteristics such as lack of social support, family history of coronary diseases and low socio-economic status. In the Netherlands, however, prospective studies of behavioural and environmental effects upon IHD are rare.

The main goal of this dissertation is to investigate how and to what extent the above mentioned behavioural en environmental characteristics, the so-called psychosocial factors, influence future IHD in the Netherlands. The data were taken from the Dutch part of the Kaunas Rotterdam Intervention Study (KRIS). KRIS involves a follow-up study of 3365 Rotterdam males, aged 45-59 years. Between 1972 and 1974 this cohort was screened for various cardiovascular risk factors and subsequently followed for approximately $9^{1 / 2}$ years to ascertain the incidences of $\mathrm{IHD}$ and causes of death.

In the underlying study, IHD in general is distinguished in 'soft events' (angina pectoris and pypass-operations), 'hard events' (non-fatal and fatal myocardial infarctions), cardiac mortality (fatal myocardial infarctions) and all manifestations of $\mathrm{MHD}$ (soft and hard events joined). In the analyses is adjusted for the somatic risk factors age, diastolic bloodpressure, cholesterol and obesity (Quetelet-index) in order to obtain valid effect estimates of the psycho-social factors. In principle, the somatic risk factors reveal a dose response relation to IHD: the higher the score on the risk factor the greater the risk of IHD.

'Hard events' are also caused by smoking, physical inactivity and a reported family history of coronary diseases. Men who smoke ten or more cigarettes daily, have, in comparison to men who never smoked a twice as great risk of 'hard events'. The results suggest further an increased risk for men in the other smoking categories. Those categories respectively concern men who stopped ten years ago or longer smoking, men who stopped less than ten years ago, the smokers of pipe and/or cigars and the smokers of 1-10 cigarettes daily. With regards to physical activity the results imply, that activity in occupation and total activity are related to 'hard events'. For both activities, measured as indexes, it holds: the less heavy the physical activity the greater 
the risk of a 'hard event'. Also attached to an increased risk of 'hard events' are a reported history of myocardial infarctions and sudden death of closest relatives. In both cases the contrast between men with a history via their parents and via their brothers or sisters (the 'double' burdened men) and the unburdened men is responsible for the association. Men with a 'double' family history of myocardial infarctions and men who are only burdened via brothers or sisters with a myocardial infarction, both have more than twice as great risk of 'hard events'. Men with a 'double' family history of sudden death have almost a three times as great risk. Stress, as measured by the 'Reeder stress scale', has no predictive value for 'hard events'. For the separately token item 'I am physically and mentally exhausted at the end of the day', referring to the in cardiovascular respect important psychological concept of vital exhaustion, holds the same. 'Hard events' are also not related to socio-economic status, measured as occupation, education, neighbourhood and an overall index which included these three factors and 'occupation of father' and 'occupation after leaving school'. Alcohol consumption on the other hand seems to affect health in a positive way. For all distinguished groups of alcohol-consumers (light drinkers through to heavy drinkers) the risk of 'hard events' is lowered. The KRIS-study doesn't support a U-shaped association for alcohol consumption as is found in other prospective studies.

Cardiac mortality also is caused by marital status and a family history of reported myocardial infarctions of closest relatives. As compared to married men, single males and widowers have approximately a three times as great risk of a fatal myocardial infarction. The same risk applies when men with a 'double' family history of myocardial infarctions are compared to unburdened men. Furthermore, physical activity in occupation and total physical activity seem to lower the risk of cardiac mortality. Socio-economic status and stress are not related to fatal myocardial infarctions. As for stress it should be emphasized that this holds only for the 'Reeder-scale' as a whole. Feelings of exhaustion at the end of the day, as measured with the separate item, are strongly predictive in the early stages of the follow-up period. During the first ten months of the follow up the risk of cardiac mortality for the exhausted men is nearly nine times as great than the non-exhausted men.

'Soft events' also are caused by physical activity in the home-work transfer and a family history of reported myocardial infarctions of closest relatives. In regards to the family history the evidence implies that the via brothes or sisters burdened men have more than three times as great a risk of 'soft events' than the unburdened men. Furthermore men who don't go to work by bicycle and/or on foot have a twice as great risk of 'soft events' than men who use a bicycle and/or walk. This effect can be viewed as a typical Dutch result.

All manifestations of IHD ('soft' and 'hard' events taken together) appear to be influenced by smoking, physical activity and a family history of coronary events. The association with a family history holds for the reported presence of a myocardial infarction and a sudden death of closest relatives. In both cases as well the via brothers 
or sisters burdened men and the 'double' burdened men have a more than twice as great risk of all manifestations of IHD than the unburdened men.

Men who smoke ten cigarettes or more, have a more than twice as great risk of all manifestations of IHD than men who don't smoke at all. Furthermore the evidence implies that physical activity is related to a lower risk of all manifestations of IHD. With regards to alcohol consumption the results suggest that drinking, irrespective of frequency and quantity, is also related to a lower risk of all manifestations of IHD. Stress and feelings of exhaustion at the end of the day appear not to be associated to all manifestations of IHD. The same applies to socio-economic status (SES), as measured by occupation, education, neighbourhood and the total index. Because of the fact that SES also doesn't influence 'soft events', 'hard events' and cardiac death, the conclusion that SES is not an independent riskfactor of IHD, seems to be appropiate.

In the above discussion, the effects of the various riskfactors were constantly expressed in terms of relative odds. This gives an indication of the strength of the effect of a certain riskfactor but says nothing about the relative contribution of that riskfactor in the magnitude of the respective heath-problem. The reason for this is that the actual amount of occurred heart diseases for each distinguished group is not taken into account. Taking into consideration the amount of heart diseases provides the following rough insights. Of all investigated riskfactors especially smoking and cholesterol and to a somewhat lesser degree age, diastolic blood-pressure and physical inactivity contribute to the development of IHD. Moreover, being physically and mentally exhausted at the end of the day provides an important short-term contribution to cardiac death. The relative contributions of Quetelet-index, a family history of coronary heart diseases, socio-economic status and marital status to the development of the distinguished manifestations of IHD can be neglected.

The results indicate that in the combating of ischemic heart diseases results can be expected if policy-measures are applied which reduce smoking and stimulate physical activity. None of the studied psycho-social riskfactors gave an indication that upon this a preventive health-program could be based. The only exception, probably, is the exhaustion factor, which contributed to an important degree in the magnitude of cardiac mortality.

A disadvantage of the KRIS-study is that the results are based on data of the seventies for a specific age-cohort of Rotterdam males. This means, strictly speaking, that the results cannot be generalised to the whole, current Dutch population. An additional disadvantage is that the KRIS-study doesn't contain repeatable measurements. Disturbances as a result of potential changes over time in the psycho-social riskfactors couldn't be taken into account. Despite the mentioned drawbacks it's remarkable that the KRIS-results, except those of socio-economic status, correspond closely with the results of other prospective studies. This correspondance makes it probable that the described effects also apply to the current Dutch population. 


\section{DANKWOORD}

Allereerst wil ik mijn beide promotores prof. dr. A. Appels en prof. dr. F. Sturmans bedanken.

Beste Ad, zonder jouw inzicht, geduld en deskundige hulp zou deze dissertatie nimmer tot stand zijn gekomen. Het was vooral jouw verdienste dat het begin jaren zeventig uitgevoerde KRIS-screeningsonderzoek een prospectief vervolg kreeg. Daarmee schiep je de grondslag voor follow-up onderzoek naar de samenhangen tussen psycho-sociale screeningsmetingen en 10-jarige incidentie van ischemische hartziekten. Ik dank je voor het feit dat je mij het vertrouwen gaf om aan de hand van "jouw" onderzoeksgegevens dit, voor Nederlandse begrippen, unieke onderzoek uit te voeren.

Beste Ferd, ook jij leverde een belangrijke bijdrage aan de totstandkoming van dit proefschrift. De vele conceptstukken die je onder ogen kreeg, werden door jou altijd prompt van deskundig commentaar voorzien. Voor de epidemiologische valkuilen, waar ik wel eens dreigde in te tuimelen, heb je me altijd behoed. Ook heb je me kunnen overtuigen dat epidemiologische onderzoeksresultaten, daar waar mogelijk, in een beleidsmatig perspectief geplaatst moeten worden. Deze aanvulling is het proefschrift stellig ten goede gekomen.

Verder ben ik dank verschuldigd aan de overige mede-auteurs van de diverse publicaties die in dit proefschrift zijn opgenomen. In alfabetische volgorde zijn dat dr. C. Mendes de Leon, drs. P. Mulder, prof. dr. J. Pool, drs. J. van Reek en dr. J. Schuurman.

Tot slot dank ik mijn huidige werkgever, het Centraal Bureau voor de Statistiek, voor de toegestane drukfaciliteiten en het toegekende bijzondere verlof ten behoeve van mijn promotiewerkzaamheden. 


\section{CURRICULUM VITAE}

Ferdy Otten is geboren op 10 mei 1958 te Heerlen, alwaar hij in 1976 het atheneum-B diploma behaalde aan het Coriovallum College. Vervolgens studeerde hij tandheelkunde aan de Katholieke Universiteit te Nijmegen, totdat hij in 1979 startte met de studie sociologie. Hij slaagde in 1985 met lof voor het doctoraalexamen sociologie met als afstudeerrichting methoden en technieken van sociaal-wetenschappelijk onderzoek. Na het afstuderen werkte hij een half jaar bij het onderzoeksbureau Goudappel-Coffeng BV te Deventer. Van $1986 \mathrm{t} / \mathrm{m} 1988$ was hij werkzaam bij de Rijksuniversiteit Limburg te Maastricht, alwaar hij epidemiologisch onderzoek verrichtte naar psycho-sociale risicofactoren van hart- en vaatziekten. Vanaf 1989 is hij als wetenschappelijk medewerker verbonden aan het Centraal Bureau voor de Statistiek te Heerlen; eerst bij de hoofdafdeling Inkomensstatistieken (tot en met 1990) en daarna bij de hoofdafdeling Sociaal-culturele statistieken. 
